\title{
INDIGENOUS INVISIBILITY IN THE CITY
}

SUCCESSFUL RESURGENCE AND COMMUNITY DEVELOPMENT HIDDEN IN PLAIN SIGHT

Deirdre Howard-Wagner

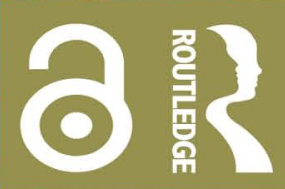




\section{Indigenous Invisibility in the City}

Indigenous Invisibility in the City contextualises the significant social change in Indigenous life circumstances and resurgence that came out of social movements in cities. It is about Indigenous resurgence and community development by First Nations people for First Nations people in cities.

Seventy-five years ago, First Nations peoples began a significant post-war period of relocation to cities in the United States, Canada, Australia, and Aotearoa New Zealand. First Nations peoples engaged in projects of resurgence and community development in the cities of the four settler states. First Nations peoples, who were motivated by aspirations for autonomy and empowerment, went on to create the foundations of Indigenous social infrastructure. This book explains the ways First Nations people in cities created and took control of their own futures. A fact largely wilfully ignored in policy contexts.

Today, differences exist over the way governments and First Nations peoples see the role and responsibilities of Indigenous institutions in cities. What remains hidden in plain sight is their societal function as a social and political apparatus through which much of the social processes of Indigenous resurgence and community development in cities occurred. The struggle for self-determination in settler cities plays out through First Nations people's efforts to sustain their own institutions and resurgence, but also rights and recognition in cities. This book will be of interest to Indigenous studies scholars, urban sociologists, urban political scientists, urban studies scholars, and development studies scholars interested in urban issues and community building and development.

Deirdre Howard-Wagner is a sociologist and associate professor with the Australian National University. Her expertise is in Indigenous policy. Her co-edited books include The Neoliberal State, Recognition and Indigenous Rights (2018), Indigenous Justice (2018), and Unveiling Whiteness in the Twenty-First Century (2015). 
Routledge Advances in Sociology

293 Mobilising Place Management Claus Lassen and Lea Holst Laursen

294 International Labour Migration to Europe's Rural Regions Edited by Johan Fredrik Rye and Karen O'Reilly

295 The Subjectivities and Politics of Occupational Risk Mines, Farms and Auto Factories

Alan Hall

\section{Civil Society}

Between Concepts and Empirical Grounds

Edited by Liv Egholm and Lars Bo Kaspersen

\section{The Economy of Collaboration}

The New Digital Platforms of Production and Consumption

Francesco Ramella and Cecilia Manzo

\section{Rural Youth at the Crossroads}

Transitional Societies in Central Europe and Beyond Edited by Kai A. Schafft, Sanja Stanić, Renata Horvatek and Annie Maselli

\section{Indigenous Invisibility in the City}

Successful Resurgence and Community Development Hidden in Plain Sight

Deirdre Howard-Wagner

\section{Socio-gerontechnology}

Interdisciplinary Critical Studies of Ageing and Technology

Alexander Peine, Barbara L. Marshall, Wendy Martin, and Louis Neven

For more information about this series, please visit: www.routledge.com/ Routledge-Advances-in-Sociology/book-series/SE0511 


\section{Indigenous Invisibility in the City}

Successful Resurgence and Community Development Hidden in Plain Sight

Deirdre Howard-Wagner 
First published 2021

by Routledge

2 Park Square, Milton Park, Abingdon, Oxon OX14 4RN

and by Routledge

52 Vanderbilt Avenue, New York, NY 10017

Routledge is an imprint of the Taylor \& Francis Group, an informa business

(C) 2021 Deirdre Howard-Wagner

The right of Deirdre Howard-Wagner to be identified as author of this work has been asserted by her in accordance with sections 77 and 78 of the Copyright, Designs and Patents Act 1988.

The Open Access version of this book, available at www. taylorfrancis.com, has been made available under a Creative Commons Attribution-Non Commercial-No Derivatives 4.0 license.

Trademark notice: Product or corporate names may be trademarks or registered trademarks, and are used only for identification and explanation without intent to infringe.

British Library Cataloguing-in-Publication Data

A catalogue record for this book is available from the British Library

Library of Congress Cataloging-in-Publication Data A catalog record for this book has been requested

ISBN: 978-1-138-58355-9 (hbk)

ISBN: 978-0-429-50651-2 (ebk)

Typeset in Times New Roman by Apex CoVantage, LLC 


\section{Cultural Advice}

Aboriginal and Torres Strait Islander peoples should be aware that the book contains references to, information about, and names of deceased persons in the text. 
$\because$ Taylor \& Francis

Taylor \& Francis Group

http://taylorandfrancis.com 


\section{Contents}

Preface

Acknowledgements

ix

List of Abbreviations

1 Introduction: making the invisible visible: the city as a critical space of Indigenous resurgence and community development

2 Settler-colonial cities as sites of Indigenous relocation: from removal to relocation

3 Indigenous resurgence in settler-colonial cities: from social movements to organisation building

4 Indigenous social economies hidden in plain sight: organisations, community entrepreneuring, development

5 A 'renewed right to urban life': reconciliation and Indigenous political agency

6 White spaces and white adaptive strategies: visibility and aesthetic upgrades and Indigenous place and space in the post-industrial city in the neoliberal age

7 Neoliberal poverty governance and the consequent effects for Indigenous community development in the city 
8 Conclusion: the wilful inattentiveness to racial inequality in cities: what Black Lives Matter protests reveal about Indigenous invisibility

Index 


\section{Preface}

This book is the culmination of 20 years of research engaging with First Nations peoples in the Australian city of Newcastle. The research on which this manuscript takes as its starting point is a four-year, place-based, qualitative case study of Indigenous community development in Newcastle dating back to the 1970s. This research has critical characteristics associated with the urban Indigenous movement, such as the formation of urban Indigenous community-owned organisations, and it predates the popularisation of a top-down Indigenous development paradigm in countries like Australia, Canada, and the United States in the 21st century (Howard-Wagner 2017). It built on a four-year sociological ethnography conducted from 2000 to 2003 and a return to the field from 2005 until 2006.

Relationships forefront my way of being, way of knowing, and way of doing research with First Nations peoples. It is how the research was conducted, building on a sociological ethnography on racism, whiteness, and Indigenous marginalisation in the city of Newcastle from 2000 to 2006 (Howard-Wagner 2006, 2009, 2015). It built on an existing relationship of openness and trust with Indigenous partners and organisations in this urban locality. The earlier project led to the one at hand. Local Koori Elders and senior position-holders in Indigenous organisations set the research agenda. Local Koori Elders and senior position-holders with Indigenous organisations presented the idea for this research at the Human Rights and Equal Opportunity Commission (HREOC) Community Consultation on Racism in Newcastle held in July 2001 in the lead up to the United Nations World Conference on Racism, Racial Discrimination, Xenophobia and Related Intolerance. A key concern among those present was a continued propensity within the mainstream to ignore local Indigenous success and preserve a deficit mentality around Indigenous issues locally. The Aboriginal and Torres Strait Islander Commission (ATSIC) Regional Councillor at the time stated: 'Media alerts from ATSIC never get used - like the release about 30 Aboriginal students accepted to study medicine at the University of Newcastle' (Howard-Wagner 2006, 250251). A representative from the local land council noted: 'There is a proliferation of racism through the media - they focus on the bad news stories' (HowardWagner 2006, 250-251). A representative from a local community-based organisation stated: 'I get calls from a young woman at the Newcastle Herald 
who rings me each month to do negative stories - only interested in alcoholism, domestic violence and bad issues and who will not report good news stories' (Howard-Wagner 2006, 250-251). The focus on failure or dysfunction 'squeeze[d] out news focusing on success, strength or "good news," which [was leading] to a distorted public perception' (Fogarty, Lovell, Langenberg, \& Heron 2018, 23). The discussion revealed not only an entrenched deficits view but also how race and racism are deeply intertwined with the framing of Indigenous failure or dysfunction in Newcastle. Such narrative framings have long been reproduced in Australian Indigenous policy about Indigenous disadvantage (Fogarty, Lovell, Langenberg, \& Heron 2018; Howard-Wagner 2018).

Success, even in the limited form of the extent to which First Nations peoples conform to a set of predetermined, measurable characteristics (Fogarty, Lovell, Langenberg, \& Heron 2018), remained invisible. It also suggested that 'success [and disadvantage] can mean quite different things to Indigenous and nonIndigenous peoples'(Finlayson 2004, 2). The collaborative research project intended to speak to such issues. Newcastle provided a significant example of successful Indigenous governance and Indigenous community building and development in practice, having set up separate community-owned and operated organisations and services that deliver government-subsidised or wholly funded programs and initiatives (Howard-Wagner 2017). Importantly too, since the 1970s, there have been many studies documenting the economic opportunities available to First Nations people in Newcastle, community needs, and migration of First Nations people from rural areas to this city (Arthur 1994; Ball 1985; Guth 1971; Guth \& Vallance 1972; Hall \& Jonas 1985; Heath 1998; Maynard 2001; Mitchell 1978).

While interviews were the primary research method, the undertaking of an in-depth, place-based case study enabled the adoption of similar methods to an ethnographic study without the heavy reliance on participant observation. The methodology and methods combined complementary constructivist and Indigenous methodologies and methods (Denzin, Tuhiwai Smith, \& Lincoln 2008; MoretonRobinson \& Walter 2009; Tuhiwai Smith 1999), such as Indigenous discussion circles (Ciftci \& Howard-Wagner 2012) used as a means of developing the research instruments and verifying the findings of the research in collaboration with the research collaborators. For example, before commencing interviews and designing the research questionnaire, a discussion circle was convened with 12 local Koori Elders. It took place in the regular setting of the Elders' local craft morning. The unrecorded discussion circle involved the author describing the intent of the research, its history, and her history with partnering with local First Nations peoples in research. The researcher then yarned with Elders for about three hours about Koori success in addressing disadvantage in Newcastle. While we weaved baskets, they weaved together a bricolage of narratives about Newcastle's Aboriginal history over the last 40 years. This knowledge assisted the design of the interview questionnaire.

The primary data (discussion circle and 70 in-depth interviews $=$ transcripts 1 to 70) was also supplemented by transcripts from interviews with Koori Elders (transcripts 71 to 76 ) and over 100 interviews conducted with local Aboriginal and/or 
Torres Strait Islander people living in the greater Newcastle region (transcripts 77 to 177) as part of the Australian Broadcasting Commission (ABC) Newcastle radio series titled Meet the Mob (ABC 2016), many off-the-record informal yarns, and print media documents. The purpose of analysing the Meet the Mob interviews is that they provided crucial historical background on community building and development in Newcastle, including the history of activism and the role of various people and organisations in furthering the rights of and addressing the needs of local Kooris. A number of those interviewed also talked about racism. The research process was complemented by successive follow-up interviews, observations, three discussion forums discussing the findings of the research, and collaborator and participant feedback on a lengthy report of the research findings. What we aimed for was to ensure that the research did not misrepresent collaborators or participants, which the researcher hopes we achieved through processes of verification. At the request of the research collaborators, these layered processes of verification took the place of co-authoring. They explained this preference by their desire to maintain a distance between the research and local Indigenous partners and organisations. Unfortunately, at the time, their reason for this and the need to do so said something too about Indigenous representation in Australian Indigenous policy spaces in terms of not only marginalisation of Indigenous voices, but the weight given to those voices.

International comparison case studies conducted over the last seven years illustrate that, while the intricate details may be different, the broader experience is the same across the settler-colonial cities of Australia, Canada, Aotearoa New Zealand, and the United States, such as Auckland, Brisbane, Chicago, Minneapolis, New York, Oakland, Phoenix, Toronto, and Vancouver.

While based on comprehensive, in-depth interviews with First Nations peoples who were generous and willing participants in this research (and some were partners in designing the research), it should be noted, however, that the author does not represent an Indigenous voice or claim an Indigenous authority. The writing of this book involves a non-Indigenous researcher imposing her theoretical and analytical understanding on to local Indigenous narratives (Christie 2008). Naming the author's location as a white female researcher has significant epistemological value in terms of positionality. Many may consider it a limitation of this book.

It is also essential to indicate the disciplinary space from which the author's voice emanates. The author is a sociologist who adopts a critical lens for understanding Indigenous invisibility in settler-colonial cities. The author draws on a wide range of tools from her critical toolkit that is a grab bag of critical theory and standpoints, including race and Whiteness approaches and Indigenous standpoints.

The book is, therefore, sociological. It centres around distinct sociological considerations: Indigenous relocation, Indigenous social movements, and Indigenous community building and development in cities. It describes Indigenous organisations as community enterprises. The chapters move through 70 years from relocation to community building to community development to an assertion of a right to the city to the present neoliberal moment. 


\section{References}

Arthur, B (1994). The Same but Different: Indigenous Socio-Economic Variation. Canberra: Australian Institute of Aboriginal and Torres Strait Islander Studies.

Australian Broadcasting Commission (ABC) (2016). 'The Making of Meet the Mob', Australian Broadcasting Commission Radio Newcastle, February 9, http://www.abc.net.au/ local/stories/2013/06/26/3789988.htm.

Ball, R E (1985). 'The Economic Situation of Aborigines in Newcastle, 1982', Australian Aboriginal Studies, Vol. 1, pp. 2-21.

Christie, M (2008). 'Digital Tools and the Management of Australian Desert Aboriginal Knowledge', in Wilson, P \& Stewart, M (eds.), Global Indigenous Media: Cultures, Practices and Policies. Durham: Duke University Press.

Ciftci, S \& Howard-Wagner, D (2012). 'Integrating Indigenous Justice into Alternative Dispute Resolution Practices: A Case Study of the Aboriginal Care Circle Pilot Program in Nowra', Australian Indigenous Law Review, Vol. 16, No. 2, pp. 81-98.

Denzin, N K, Lincoln, Y S \& Tuhiwai Smith, L (2008). Handbook of Critical and Indigenous Methodologies. Newbury Park, CA: Sage.

Finlayson, J (2004). Success in Aboriginal Communities: A Pilot Study. Canberra: AIATSIS.

Fogarty, W, Lovell, M, Langenberg, J \& Heron, M J (2018). Deficit Discourse and Strengths-Based Approaches: Changing the Narrative of Aboriginal and Torres Strait Islander Health and Wellbeing. Melbourne: The Lowitja Institute.

Guth, S O (1971). Interim Report: Newcastle Aborigine Research Project. Armidale: The University of New England.

Guth, S O \& Vallance, G A (1972). Aboriginal Rural-Urban Migration: The Newcastle Project. Armidale: University of New England.

Hall, M \& Jonas, W J A (1985). On the Fringes of Newcastle Society-A Matter of People, with a Note/by J. Doherty. Newcastle, NSW: Awabakal Newcastle Aboriginal Cooperative Ltd in Association with the NSW Ministry of Aboriginal Affairs.

Heath, J (1998). 'Muloobinbah: The Contributions of Aboriginal People to the Resources of the Hunter Region', in Hunter, C (ed.), Riverchange. Newcastle: Newcastle Region Public Library.

Howard-Wagner, D (2006). Post-Indigenous Rights - The Political Rationalities and Technologies Governing Federal Indigenous Affairs in the Contemporary Period. PhD Dissertation, University of Newcastle, Newcastle.

Howard-Wagner, D (2009). 'Whiteness, Power Relations, Resistance and the Practical Recognition of Indigenous Rights in Newcastle', Theory in Action, Vol. 2, No. 1, pp. 40-65.

Howard-Wagner, D (2015). 'Governing Through Neoliberal Multiculturalism: Reconstituting Australian Culture and Cultural Diversity in the Howard Era, 1996-2007', in Watson, V, Howard-Wagner, D \& Spanierman, L (eds.), Unveiling Whiteness in the Twenty-First Century: Global Manifestations, Transdisciplinary Interventions, pp. 89-114. New York: Lexington Books.

Howard-Wagner, D (2017). 'Successful Urban Aboriginal-Driven Community Development: A Place-Based Study of Newcastle', CAEPR Discussion Paper.

Howard-Wagner, D (2018). 'Governance of Indigenous Policy in the Neo-Liberal Age: Indigenous Disadvantage and the Intersecting of Paternalism and Neo-Liberalism as a Racial Project', Ethnic and Racial Studies, Vol. 41, pp. 1132-1151.

Maynard, J (2001). 'Muloobinbah (Newcastle) an Aboriginal Industrial Presence: Past and Present', Journal of Royal Australian Historical Society, Vol. 87, No. 2, pp. 248-266. 
Mitchell, I S (1978). Aborigines on the Move: Personal Adjustment in the Resettlement of Aboriginal Families: A Psychosocial Study. Doctoral Dissertation, University of New South Wales, Sydney.

Moreton-Robinson, A \& Walter, M (2009). 'Indigenous Methodologies in Social Research', in Bryman, A (ed.), Social Research Methods. South Melbourne, VIC: Oxford University Press.

Tuhiwai Smith, L (1999). Decolonising Methodologies: Research and First Nations Peoples. London and New York: ZED Books. 


\section{Acknowledgements}

This book is produced from a study titled 'Indigenous Societies, Governance and Wellbeing: Indigenous Success in Addressing Indigenous Disadvantage and Improving Indigenous Wellbeing', which was made possible through the Australian Research Council's Discovery Early Career Research Award funding scheme (project number DE120100798). The views expressed herein are those of the author and are not necessarily those of the Australian Research Council. This research has benefited enormously from, and would not be the same without, lengthy discussions and engagement with local Aboriginal people during the design, development, and feedback phases of the project. It would not have been possible without the contribution of interviewees who collaborated in the research. I thank everyone for their generosity, not only for sharing their time in discussing the research design, but also for participating in lengthy, meaningful interviews and sharing their knowledge, stories, and rich understandings.

To all the individuals that I have the opportunity to learn from, thank you. Without you sharing your knowledge and experiences and your support for the research, the book would not exist.

Thank you to the Australian National University for its institutional support throughout the manuscript process, and thank you to colleagues who read chapters for their support.

Thank you too to my beautiful daughter, Indira. 


\title{
Abbreviations
}

\author{
ABS Australian Bureau of Statistics \\ ATSIC Aboriginal and Torres Strait Islander Commission \\ CDEP Community Development Employment Projects \\ COAG Council of Australian Governments \\ HREOC Human Rights and Equal Opportunity Commission \\ IAS Indigenous Advancement Strategy \\ LDM Local Decision Making \\ NAIDOC National Aborigines and Islanders Day Observance Committee \\ OCHRE Opportunity, Choice, Healing, Responsibility, Empowerment(NSW Plan \\ for Aboriginal Affairs: Education, Employment and Accountability) \\ SAAP Supported Accommodation Assistance Program
}


$\because$ Taylor \& Francis

Taylor \& Francis Group

http://taylorandfrancis.com 


\title{
Introduction
}

\author{
Making the invisible visible: \\ the city as a critical space of \\ Indigenous resurgence and \\ community development
}

Seventy-five years ago, First Nations peoples began a significant post-war period of relocation to cities in the United States, Canada, Australia, and Aotearoa New Zealand. ${ }^{1}$ The relocation period was a turning point in history - it was a period of rupture and a critical narrative site of Indigenous recovery and resurgence (Furlan 2017, 10). First Nations peoples came together in American, Aotearoan, Australian, and Canadian cities - restoring their capacity to be responsible for their future, creating new diasporic communities, complicating what it means to be 'Indigenous', and unifying as self-determining peoples to seek solutions to their own problems (Ahmet 2001; Heritz 2013, 43; Furlan 2017).

The city as the terrain of persistent settler colonialism was contested through Indigenous struggles for life projects, land, the right to the city, and selfdetermination. Transformative Indigenous social movements endeavoured to actualise a right to the city and further the rights of First Nations peoples to cultural resurgence in cities through the creation of self-governing, community-based and community-owned First Nations organisations. A strong base of community organisations were created in cities - the Phoenix Indian Center, the Oakland Intertribal Friendship House, the Chicago American Indian Centre, the Awabakal Cooperative, the Vancouver Aboriginal Friendship Centre, and the Manukau Urban Maori Authority and Te Whanau O Waipareira in Aotearoa New Zealand, to name a few.

Indigenous resurgence in cities was a practical, grounded mode of being and resistance (Simpson 2011, 17; Furlan 2017; Elliot 2018, 64). Indigenous social economies arose out of a process of renewal of culture and community life in cities and through the formation of communities of association, Indigenous institutions, and social infrastructure. Many cities in Australia, America, Aotearoa, and Canada now have well-developed Indigenous institutions and social infrastructure: 13 Indigenous organisations established in the city of Newcastle; 16 in the suburb of Redfern in Sydney's inner west; 20 in the cities of Brisbane, Chicago, and the region of Western Sydney; 25 in Vancouver. These are Indigenous institutions that operate as a loose confederation of multiple Indigenous social, health, employment and training, educational, transport, justice, cultural 
and recreational utilities and assets. Indigenous institutions are powerful symbols of Indigenous agency, resistance, and recovery.

The Awabakal Cooperative located in the Australian city of Newcastle is a powerful symbol of this period of rupture, recovery, and resurgence. The city of Newcastle, like the cities of Auckland, Chicago, Minneapolis, New York, Oakland, Phoenix, Sydney, Toronto, and Vancouver, became a place where First Nations peoples with different life stories relocated to and engaged in the renewal of Indigenous life projects and new visions of the world (Blaser 2004). Post-World War II relocation saw First Nations peoples move to specific localities in cities, such as Little Earth in Minneapolis, the Block in Redfern, and Uptown in Chicago. In other cases, communities of association in cities like Newcastle and Oakland were not located within a specific clustered residency or neighbourhood but somewhat widely scattered and came together at meeting places. The 'glue' that held First Nations peoples together in cities was the formation of community-based and community-owned organisations that served as the heart of newly formed communities of association (Putnam \& Feldstein 2003). It was a 'movement moment' in which First Nations peoples organised themselves in collectives, networks, and created nested hubs of Indigenous organisations in cities.

In Newcastle, Kooris found a way of moving away from assimilatory practices, mainstream service delivery, and government and faith-based intervention. Kooris established an Indigenous economy of care and wellbeing in this city. Kooris were doing business in a way that reflected culturally inherent philosophical contexts, restoring Indigenous forms of governance. Indigenous social relations, governance, language, culture, and cultural identity were at the heart of community development in this city. Empowerment, self-determination, and improved community wellbeing followed.

Today, longstanding Indigenous institutions, communities of association, and community development in cities face new challenges. First Nations peoples, whose home-place has been in the suburb of Uptown on the city's waterfront North Side district in Chicago for the last 70 years, are now dispersed across the city. The American Indian Centre has been pushed out of the prime city locality by encroaching gentrification after operating out of the former Masonic temple for 50 years (Lee 2016, 1). The same is happening in the Sydney suburb of Redfern. Sixteen Indigenous organisations remain in Redfern, including the longstanding Aboriginal Legal Service and Aboriginal Medical Service established in the 1970s as mechanisms through which Kooris living in Redfern and Waterloo accessed self-determination and their right to the city. Redfern is the locality of the well-known urban Aboriginal enclave 'the Block'. At its peak, 40,000 Aboriginal and Torres Strait Islander people lived in Redfern (Latimore 2018). Today, there are 284 Aboriginal and Torres Strait Islander people living in the suburb of Redfern (ABS 2016).

The highly successful Intertribal Friendship House in the American southwestern coastal city of Oakland in the San Francisco Bay area, the Native Canadian Centre of Toronto, and the Awabakal Aboriginal Cooperative in the 
Australian south-eastern coastal city of Newcastle are the exception. The Awabakal Cooperative has managed to maintain its place in a central locality on the thoroughfare of the inner-city harbourfront suburb of Wickham in the reclaimed industrial dockland area. It has occupied this locality for over 30 years. The surrounding area, including the inner-city industrial harbourfront, has renewed and gentrified around it. The cluster of motor mechanics workshops, semi-industrial businesses, and corner pubs have been demolished and replaced with modern apartment blocks. The Awabakal Cooperative retains its central locality between the three suburbs where most Kooris live, which are Carrington $(7.2 \%, \mathrm{n}=138)$, Mayfield $(4.2 \%, \mathrm{n}=393)$, and Waratah $(4.5 \%, \mathrm{n}=204) .{ }^{2}$ While these locations have all undergone processes of gentrification and urban renewal, the demographics of these suburbs have not yet drastically changed.

If poverty were suburbanised relocating social housing tenants, as in Chicago and Redfern, and now in Vancouver and Oakland, the effect would be devastating. First Nations people living in Carrington have formed a community in itself. The suburb is designed like a country town with a main street that houses residents, and retail shops and services have that small-town community vibe - everyone knows everyone. First Nations artist, Uncle Billy Lamb, lives in a semi-detached social housing terrace on the main street. Uncle Billy, a proud Wiradjuri man, is the heart of the Carrington community. He is involved in the Awabakal Local Aboriginal Land Council. He knows all that is going on. He keeps the community informed, sharing news, looking out for everyone. Most of the day he sits on his porch, now often with his young adult granddaughter, doing artwork or sounding rhythmic beats on his didgeridoo, yarning with residents as they pass by. $\mathrm{He}$ painted the mural at the local public school, and his artwork is displayed on the brick wall of a local shop along the southern boundary of his small front yard. All over the walls of his home are artwork that are a testament to his talent. While Carrington once housed the Texas Shanty Town and a mix of the destitute and lower working class, the demographics of Carrington are changing. It has a rich collection of historical buildings and housing architecture that is highly sought after, making it a prime location for gentrification and Indigenous displacement.

While this form of Indigenous relocation and displacement associated with gentrification has not occurred in Newcastle, a new politics of non-recognition means that the Awabakal Cooperative faces other challenges in the neoliberal age. The Awabakal Cooperative finds itself marked today not as a successful selfgoverning Indigenous institution but as an Indigenous social service organisation. Today, differences exist over the way governments and communities see the role and responsibilities of Indigenous institutions in cities. Governments simply see Indigenous institutions as providing culturally appropriate services for First Nations peoples. What remains hidden in plain sight is their societal function as a social and political apparatus through which much of the social processes of Indigenous resurgence and survivance have occurred in cities. Today, the struggle for self-determination in Australian, Canadian, Aotearoan, and American cities plays out through First Nations people's efforts to sustain their own institutions. 


\section{White intrusion - co-location in a mainstream social service system}

It is the building and space it operates out of, rather than its locality, or place in society, that symbolically reveals a great deal about the Awabakal Cooperative's marked invisibility in the city today. The Old Wickham Infant School is a simple yet imposing two-storey heritage building constructed in 1892. The Romanesque style architecture references Victorian gothic influences. It has decorative polychromatic brickwork, and a bell-cote roof.

A mainstream charity organisation owns the far more extensive, more imposing historical public school next door. It is a two-storey Edwardian red brick building with its decorative polychromatic brickwork and curved roofline, high brick gables, copper-roofed ventilator towers, arched porches, brick and wrought iron fence, and wrought iron art nouveau gate. It accommodates homeless and at-risk youth studying or training in the greater Newcastle region. The mainstream charity bought the building from Newcastle City Council for one dollar in 2012 .

Co-location calls to mind the history of white intrusion - from the state to faith-based organisations to social workers - in the lives of First Nations peoples. White intrusion is one of the many reasons that Kooris set up self-governing organisations in Newcastle. Through their organisations, First Nations peoples found ways of sidestepping the white welfare system and creating small-scale versions of their ideals in the cities of Auckland, Brisbane, Chicago, Newcastle, New York, Phoenix, San Francisco, Sydney, Toronto, and Vancouver. In the past era of state recognition, First Nations organisations in cities became important expressions of Indigenous agency, empowerment, autonomy, and self-determination. They intended to do business their way, following the needs of local First Nations peoples. This intent differed from how the state, professional experts, and faithbased organisations have historically perceived their needs.

Co-location signifies how the Awabakal Cooperative now competes with mainstream, not-for-profit, faith-based organisations to deliver services to individualised disadvantaged 'Indigenous citizens' in the era of neoliberal poverty governance. Neoliberal poverty governance, particularly Closing the Gap and overcoming Indigenous disadvantage as a racialised project, has been given limited sociological consideration in Australia (Walter 2009; Howard-Wagner 2017), but it is explored in detail by sociologists and philosophers in the United States, particularly in relation to the intersectionality between race and poverty governance in the neoliberal age (Winant 1994, 2004; Wacquant 2010; Soss, Fording, \& Schram 2011; Mills 2015). American scholars show the persistent power of race in poverty governance in the neoliberal age (Soss, Fording, \& Schram 2011).

\section{Subjugation of Awabakal sovereignty}

The façade of the building and its white history also render invisible the Awabakal significance of the site. It sits about 200 meters from a historical Awabakal 
gathering place used as late as 1852 , known now as the 'Wickham Corroboree ground' ${ }^{3}$ Its invisible coexistence alongside this significant history signifies the invisibility of Awabakal history. The history of the traditional Awabakal owners, whose territory encompasses Newcastle, is hidden in plain sight. Significant Awabakal sites along Newcastle's formerly industrial, but recently reclaimed, trendy foreshore are now subjugated by western architecture. The ongoing construction of new architecture on significant Awabakal sites testifies to the resilience of colonially produced institutional practices and the bureaucratisation of processes of land. The Ibis hotel, the Kentucky Fried Chicken fast-food restaurant, the new inner-city University site, and the Newcastle rail corridor are all recent, separate construction sites where significant Awabakal artefacts were disturbed (Smee 2011; Harris 2015). The land on which the newest Kentucky Fried Chicken fastfood restaurant was built on Newcastle's Hunter Street is 'one of the country's most significant cultural heritage sites' (Shoebridge 2011, 1).

Despite the existence of Awabakal artefacts, the construction of these buildings went ahead, continuing the erasure of known history (Tatz 2003), or whiting out of the past, and this form of malevolent absence continues to facilitate invisibility in the present (Birch 2005). The occasional reference to Awabakal history is on 'a few official interpretive signs alongside detailed white histories at local monuments' (transcript 80). If one catches the ferry across the harbour from Newcastle to Stockton, one's attention may be drawn to a sign with the word Muloobinba foregrounded on Koori artwork. Muloobinba is the Awabakal name for Newcastle. Along the foreshore, there is also public art shaped in the form of cement ships with Awabakal place names carved into them. Newcastle's colonial and convict history and Awabakal traditional stories, such as the story of the Giant Kangaroo, are merged as one in public art or local signage. The marking of the Awabakal history is contained to the new trendy foreshore area - the hub of Newcastle's tourist attractions.

The occasional reference to Awabakal history and words in signage creates a false impression of reconciliation in the city. It renders invisible the objections local Awabakal people have lodged against development. It renders invisible their declarations that 'the majority of building constructions within the Newcastle City Council region are being approved without any consideration to the Aboriginal Cultural Heritage that still remains within the Newcastle Regional Footprint' (Awabakal Traditional Owners Aboriginal Corporation 2014, 1). It renders invisible the continuing struggle against development and its threats, such as the encroachment of a housing development on the Awabakal women's Butterfly Caves.

\section{The invisibility of Indigenous community development and cultural resurgence}

Behind the façade of the heritage building that houses the Awabakal Cooperative sits one of the most successful not-for-profit Indigenous community organisations in the Australian state of New South Wales, which has the largest population of 
Aboriginal and Torres Strait Islander peoples in Australia. While starting as a gathering place for Kooris relocating to Newcastle in the 1970s, the social innovation and entrepreneurship of its successive chief executive officers and boards saw it go on to create the Awabakal Medical Centre, Awabakal preschools, and Awabakal early childhood and childcare services, as well as many cultural and social programs designed to improve the wellbeing of local Kooris. The social fabric of this community of association became the vehicle for entrepreneurship (Peredo \& Chrisman 2010). It was an umbrella organisation out of which came Yarnteen Aboriginal and Torres Strait Islander Corporation, Wandiyali Aboriginal and Torres Strait Islander Corporation, and Miromaa Language and Technology Centre. It has been the glue that holds the Koori community in this city together. It has played a distinctive role in society by progressing the rights of Kooris to selfdetermination and community development. It has also proven essential to advocacy, the maintenance of community development, and the creation of new social infrastructure, with its success resulting in both economic and social outcomes. That it represented 'community' enabled it to leverage resources from governments to build Indigenous social infrastructure locally from the 1970s to the turn of the 21 st century. Its first government grant was under $\$ 15,000$. Today, it generates an income of, and spends, over $\$ 10$ million per year (Awabakal Annual Report 2014). It describes itself as a 'leading example of Indigenous community power in Australia' (Awabakal Ltd 2016).

Awabakal Cooperative, Yarnteen Aboriginal and Torres Strait Islander Corporation, Wandiyali Aboriginal and Torres Strait Islander Corporation, and Miromaa Language and Technology Resource Centre were a loose confederation of Indigenous institutions in the city of Newcastle. This loose alliance 'consisted of an elaborate network of organisational governance and senior leaders who focus on community service delivery, economic development, cultural identity, language and land' (Smith 2008, 4). This loose confederation or alliance of organisations created diverse employment opportunities and pathways for local Kooris.

The revitalising and strengthening of Indigenous social relations, governance, language, culture, and cultural identity is intertwined with and indivisible from overcoming Indigenous disadvantage in this city. That is, Indigenous social relations, governance, language, culture, and cultural identity are vital community resources in overcoming Indigenous disadvantage. Indigenous organisations, programs, and services improved socio-economic outcomes and social conditions in culturally appropriate and less discriminatory ways (Howard-Wagner 2017). Koori endeavours to do so reinforce a long-held belief that overcoming Indigenous disadvantage is not as simple as getting an education and/or a job. That is, historical and contemporaneous racialised social relations and epistemologies matter.

Indigenous community development in cities has become, as it will be argued, in a purposeful and critical sense wilfully invisible in policy spaces in the neoliberal age. The deliberate and pernicious political and social practices that operate to render Indigenous community development and cultural resurgence invisible at the same time regulate the regimes of visibility circulating throughout the 
political and social body itself, determining what can legitimately be rendered visible and how. Invisibility concerns the wilful ignorance of the success of Indigenous community development, the significant Indigenous social infrastructure, and the success of First Nations organisations in cities. That is, it is a political rationality that ignores a pre-existing, self-determining subjectivity. A subjectivity in which First Nations organisations operate as social, political, and economic entities charged with progressing community development and the right to selfdetermination in this city. Policymakers wilfully ignore the more nuanced, agential, bottom-up Indigenous governmentality in which Indigenous actors in cities have engaged in governing various fields of activity.

While occupying its own significant and prominent place in this post-industrial city, which symbolises cultural resurgence and self-determination, the neoliberal state simply sees the Awabakal Cooperative as an Indigenous social service organisation. This new way of seeing subjugates and imposes new limits on the recognition of Indigenous status in cities in the contemporary moment. Ways of seeing Indigenous organisations, people, and culture bring into play new processes of racialisation in cities. Invisibility occurs in the context of not seeing. It also occurs through the politicisation of Indigenous legitimacy and authenticity in cities. It reflects the 'social poison of race theories' (Langton 2012, 4). The invisibility of successful urban Indigenous community development in cities and the central role that First Nations organisations play are hidden in plain sight. In the neoliberal age, the possibilities of practising systems of governance and maintaining Indigenous social economies in cities is increasingly hindered.

Today, First Nations organisations as forms of not-for-profit organisations are enlisted as both subjects and objects of social policy delivery in the project of overcoming individual Indigenous socio-economic disadvantage (Meade 2018, 222). First Nations organisations are responsibilised as sites and solutions to the problems of individual Indigenous socio-economic disadvantage while also problematised, controlled, and managed as sites of inefficiency, corruption, and as 'failed experiments of self-determination' (Vanstone 2004). At the same time, they are professionalised through western governance and leadership training, accreditation, and contractual arrangements. This way of doing business with First Nations organisations draws First Nations peoples back into a historical racialised cycle of adaptation. There is Indigenous loss. First Nations peoples are once again engaged in a struggle to change the terms and conditions of their colonised existence in the face of changing oppressive government administrative regimes. Indigenous adaptation and resilience occur in order to maintain survival and resist oppressive forces.

Like Ralph Ellison's Invisible Man, local Kooris struggle with the imperceptibility that cloaks their journey in pursuing Indigenous community development, self-determination, and resurgence in this city (Ellison 1952). Invisibility concerns the desire to be socially seen as rebuilding and reclaiming the rightful place of First Nations peoples within this city. Having a voice, being heard, being seen or understood is the desired state. Seeing the institutions and governance 
structures created is the desired state. Recognising the social capabilities of the community to mobilise Indigenous social relations, governance, language, culture, and cultural identity to overcome the disadvantage that First Nations peoples experience is the desired state. Instead, Indigenous community development and reterritorilisation are marginalised and made insignificant through contestation and the imposition of pervasive neoliberal rationalities governing Indigenous policy in the contemporary moment.

\section{Enacting visibility does not equate to ontological and epistemological seeing}

First Nations organisations do not simply deliver services. First Nations organisations arose out of social movements. They have remained critical to political mobilisation and social change in cities. They are not detached from the localised and national struggle for Indigenous rights, self-determination, recognition, and empowerment.

Community building in cities occurred in a distinct period of Indigenous resurgence, anti-colonial politics, and actions of Indigenous solidarity and a time of significant international change as well. The battles were especially intense in the 1970s, a crucial period of Indigenous rights activism across the four settlercolonial nations of Australia, Canada, Aotearoa New Zealand, and the United States. In part, this localised struggle can be read in the context of Aboriginal activist James Miller's notion of 'Awakening' (Miller 1985), even as the formation of what Paul Havemann calls a 'community of resistance' (Havemann 1999), and as deeply entrenched in what Deborah Yashar describes as the struggle for Indigenous rights (Yashar 1999, 2005; Petray 2010, 2012; Dahl 2012). This moment saw the rise of Indigenous grassroots movements in cities. Indigenous occupations, protests, marches, and commemorations in cities, such as Occupy Alcatraz, were not simply directed toward land rights but also toward a right to the city and Indigenous rights nationally. While drawing attention to the struggle for First Nations peoples' rights, including land rights nationally and internationally, the 89 First Nations peoples from the San Francisco Bay area who occupied Alcatraz for 19 months beginning 20 November 1969 expressed a local vision and desire for a space for the local First Nations community, which came after the San Francisco Friendship Centre had burnt down.

Cities became critical sites of Indigenous protest and movements. The American Indian Movement was established in the American city of Minneapolis in 1968. The formation of the Aboriginal Tent Embassy on the lawns of the Australian Parliament House took place in the city of Canberra in 1972. The Tent Embassy is still there today. The Kaurna peoples engaged in an 18-year legal battle for recognition of native title over the land on which the Australian city of Adelaide was built. Indigenous political and social movements in cities are important reminders of the significance of settler-colonial cities as sites and catalysts of decolonisation (Tomiak 2016, 9). 
Social mobilisation and protest have remained a critical aspect of enacting visibility in settler-colonial cities over the last 70 years. Indigenous mobilisation and reoccupation of the city have occurred in the everyday moment, such as the recent presence of a wave of more than 20 large painted tepees erected in Toronto's Nathan Phillips Square to honour the legacy of residential school survivors. The enactment of visibility is more than a struggle for the right to the city; it entails resistance to the ongoing settler-colonial state project of dispossessing, disappearing, and erasing First Nations peoples. It entails a contestation of the city as terrain of persistent settler colonialism through persistent anti-colonial Indigenous struggles for life, land, and self-determination, including the struggle over the meaning and definitions of territory, place, scale, identities, and modes of governance (Tomiak 2016, 9). The organisations that First Nations peoples created in cities have been critical to this agenda.

The process of unsettling is a process of bringing First Nations peoples back into place. The social process of unsettling may involve repossessing the stories and place names that remain hidden from view under western architecture. First Nation peoples in cities engage in practices that agitate and unsettle cities, bringing the First Nation storied landscape back into place. On visiting Columbia University in New York in 2019, a colleague advised that there was a plaque in the quad in front of the university's John Jay Hall that honoured the First Nations Lenape people of the land New York now occupies. It took considerable time to locate the plaque. It is small and located next to the edge of the footpath in front of a hedge in John Jay Hall quad. It was First Nation students who agitated for the placement of the plaque on the grounds of Columbia University. The only other recognition of the Lenape First Nations peoples as the original occupants of New York is a statue in lower Manhattan commemorating the Lenape First Nations people's sale of their land to the Dutch in 1626. It tells a 'story' challenged as 'an outright fabrication' (Zunigha, quoted in Connolly 2018, 1). Today, there are descendants of the Lenape First Nations peoples who remain in New York. However, many Lenape now live in Oklahoma, where they were relocated, and belong to the federally recognised Delaware Nation. The Lenape First Nations people, whom the settler colonisers came to term the Delaware, now mostly live in Canada and Oklahoma as a result of displacement and US Indian policy.

While there are descendants of the Lenape First Nations peoples who continue to live in New York, they cannot reclaim their homeland. First Nations organisations established by First Nations peoples who relocated to the city of New York, such as the Redhawk Native American Arts Council, have been actively engaged with the Lenape First Nations people in bringing them back onto their homeland and restoring the Lenape First Nation back into place. In 2018, the Lenape hosted a Pow Wow on Park Avenue in New York. It was the first Lenape Pow Wow in New York since 1700. It was an important moment in the marking of ten sites in Manhattan that reflect the legacy of the Lenape (Levine 2018).

On Columbus Day weekend in 2015, for the first time ever in New York City, 6,000 First Nations peoples and their supporters gathered on Randall's Island to 
celebrate the 523-year survival of First Nations cultures and traditions. The event received worldwide media coverage and was the beginning of a movement for changing the celebration of Columbus Day to a celebration of First Nations Peoples Day in New York City. Five years later, on 13 October 2019, First Nations peoples gathered once again in the city of New York to provoke the rethinking of Columbus Day. On 13 and 14 October 2019, a consortium or loose confederation of over 13 First Nations organisations and groups from not only the New York City area but across Turtle Island unified to push to have New York City follow in the footsteps of other cities, states, and schools such as San Francisco; Los Angeles; Alaska; Vermont; Multnomah County, Oregon; St. Paul, Minnesota; Olympia, Washington; Traverse City, Michigan; and Albuquerque and Sandoval County, New Mexico to replace Columbus Day with First Nations Peoples Day. First Nations organisations were coming together to call on Americans to rethink who Columbus was and what Columbus Day symbolised to First Nations peoples of Turtle Island. A two-day pow wow took place on the Harlem River field in front of the Icon Stadium on Randall's Island. On 14 October, there was a sunrise ceremony honouring First Nations peoples around the world who have endured and survived genocide.

The invisibility of Indigenous displacement, alienation, and estrangement remains a key characteristic of modern city life. Indigenous resurgence is a complex social and cultural process that necessitates unsettling the possessive investment in whiteness in order to restore, regenerate, and repatriate Indigenous life and nationhood in the city. The act of becoming visible in one's own territory is a powerful act of decolonisation (McElroy 2017). Put simply, the streets and schools and parks of settler-colonial cities were named during a time when most leaders and states were doing everything in their power to keep cities and the nation as white as possible - and the architecture of cities reflects that (McElroy 2017). Suburb and street names, signage, plaques, and commemorations convey a significant visual message about the place of First Nations peoples in cities. The reinstating of First Nations back in place goes beyond the recognition of significant sites, place names, and stories. It is through the exercising of Indigenous rights to the city that the prerogatives of settler-colonial development are challenged. New forms of Indigenous agency and resistance arise out of such processes, including the political pressure First Nations peoples generate by demanding the right to claim land, to protect significant sites, and to arbitrate and intervene in development processes in cities.

The significance of the removal of symbols of colonial oppression is that it decolonises public space. It unsettles a possessive whiteness in settler-colonial cities. The public process to remove colonial statues is a significant part of the social and political process of ending historical injustice and violence of the settler nation-state, such the recently removed 'Early Days' statue on Fulton Street between Hyde and Larkin Streets in the Civic Centre of San Francisco, California. The statue depicts a First Nations person at the feet of a Catholic missionary and Spanish cowboy. It is through political mobilisation and contestation that 
change has occurred. Political mobilisation and contestation led to the placement of boards over the 'Life of Washington' fresco series at George Washington High School in San Francisco, which includes images of slaves and a dead First Nations person. Political mobilisation and contestation led to the renaming of McBride Park in Vancouver, named after a former Premier who said 'we stand for white British Columbia, a white land and white Empire'. Mobilisation and contestation led to the renaming of Trutch Street in Vancouver, named after the British Columbian first lieutenant-governor, who is well-known for reducing the size of Indigenous reserves (McElroy 2017). Political mobilisation and contestation led to the renaming of Rue Amherst in Montreal, named after General Amherst, who is renowned for his racist and genocidal practices toward First Nations peoples.

Communicating politically through mobilisation and protest has been a critical part of the political project of Indigenous cultural resurgence in Newcastle. First Nations organisations have been the 'voice' of the community. They represent the community in the political space. For over 30 years, they played a significant role in expressing dissent and mobilising protest so that the voices of Kooris were heard. It is the Awabakal Cooperative and its members who erected a tent embassy on the lawns of Newcastle in the 1980s after the NSW government cut its funding. It is representatives of First Nations organisations who have used the political tools at their disposal to bring about social change. It is representatives of First Nations organisation and their members who have advocated for Indigenous institutions, infrastructure, and community development. It is representatives of First Nations organisations who contribute to the debate about development in the city of Newcastle. It is representatives of First Nations organisation who used the federal reconciliation policy as a vehicle for cultural resurgence and a right to the city. It is representatives of First Nations organisations that compelled the city to sign the Hunter Peoples Commitment to First Nations peoples. It is the representatives of First Nations organisations that pushed for Newcastle to develop the first treaty in an Australian city. It is the representatives of local First Nations organisation that pushed for the recognition of Awabakal place names and significant sites. The political projects of community representatives have been long games. It took over 20 years following the signing of the Hunter Commitment to First Nations Peoples to have place names recognised, and there remains an ongoing struggle for greater recognition of Awabakal sites and places names.

The rights of representatives of First Nations organisations to advocate and dissent has been curtailed in the 21 st century. First Nations organisations, which are dependent on governments for funding, have found that their capacity to do so has been contained and remapped through explicit anti-advocacy clauses included in government funding contracts. The silencing of dissent and advocacy and the professionalisation of First Nations organisations through government contracts has had the effect of silencing protest in the form it previously took in this city. First Nations organisations endeavour now to maintain effective and harmonious relationships with government because of funding dependency. It has not only silenced Indigenous voices and rendered invisible Indigenous dissent in the public 
domain but also ostracised First Nations peoples from the processes of decisionmaking. Serious criticism and dissent are now expressed privately. The invisible is intrinsic to the visible - without public dissent, there is no problem in the city. Indigeneity is still appropriated in the city of Newcastle, and the nation, to present an image of a reconciled landscape free of a history of colonisation (MoretonRobinson 2008, 89).

Indigenous autonomy and self-governance in cities, like reconciliation, becomes a casualty of the shifting neoliberal state and the pendulum having swung too far. While Indigenous/state relations move into a space of misrecognition and disrespect, refusal is not yet an option (Simpson 2014; Coulthard 2014; Coulthard \& Simpson 2016).

\section{The intertwining of invisibility/visibility}

Australian creative writing academic Paul Collis, who is a Barkindji man born in Bourke in far western New South Wales on the Darling River, argues that 'visibility is of profound importance, both as a concept and as a category' (Collis \& Web 2014,490 ). The reason being is that we 'cannot know each other in an ontological or an epistemological sense if we cannot, or do not, or will not, see each other' (Collis \& Web 2014, 490). Collis and Web argue that invisibility and visibility are intimately intertwined.

Invisibility is used in a political, sociological, and psychological sense, rather than merely a visual sense. Visibility concerns the ontological and epistemological attentiveness of seeing in terms of relational relevance. Visibility centres rather than ignores and denies Indigenous lifeworlds and life projects in cities. Invisibility brings into play asymmetries of power. Sociologically then, the process of making visible settler-colonial cities as sites of Indigenous relocation and resurgence entails centring the settler-colonial cities as complex sites where cultural, political, and societal relationships between First Nations peoples and the state and other citizens play out.

The reference to Indigenous invisibility in cities itself is not new. Canadian sociologist David Newhouse, who is an Onondaga from the Six Nations of the Grand River community near Brantford in Ontario and a leading Indigenous scholar on urban Indigenous affairs in Canada, describes what First Nations peoples have created in cities as 'the invisible infrastructure' (Newhouse 2003). Newhouse is referring to the limited knowledge about Indigenous organisationbuilding and development in policy and research contexts and the fact that First Nations peoples' institution-building and development in cities (and their outcomes) are poorly understood in policy and research contexts.

This book ontologically and epistemologically renders visible Indigenous resurgence and community development in cities. It calls for rethinking and revaluing of Indigenous social economies in cities. This approach creates new imaginings of possibilities (Bargh 2007; Bargh \& Otter 2009; Howard-Wagner, Bargh, \& Jimenez 2018). 


\section{Invisible loss and wounded settler cities}

The city itself is an important but neglected strategic site in which reconfigurations of Indigenous relations with the state and broader society play out. The struggle for the right to the city entails a struggle against the location of First Nations peoples outside the city in the contemporary colonial imagination. It necessitates challenging the condition of seeing or the epistemic, political, and nuanced ignorance of First Nations peoples' place in settler-colonial societies as something produced and sustained as not only outside cities but also as marginal to the politics and economics of cities.

The invisibility metaphor is a means of reinstating the city as a critical space through which the politics of colonisation, decolonisation, and recolonisation play out across time. It is a metaphor long deployed in studies of race and whiteness. It concerns, too, the broader discussion about how ways of seeing cities and thinking about cities remain deeply racialised (Keith \& Cross 1993; Goldberg 1993, 2017; Razack 2014; Lobo 2016). It is not a new proposition to explore Indigenous invisibility in cities or to untangle the urban powers of whiteness (Shaw 2007) or settler colonialism (Tomiak 2016). However, what is original is to make visible the success of urban First Nations peoples. The active social movements in cities. The building of Indigenous communities of association in cities. The community development that occurred. The social economies created. The social infrastructure built. The positive effects this has for addressing the disadvantage that Indigenous communities in cities experience.

In making visible Indigenous political and cultural resurgence in settlercolonial cities, it is crucial to address the political absence of acknowledgement of this in the mainstream policy space, exposing this as a form of malevolent absence. Invisibility occurs in the context of not seeing, but it also occurs as a form of neo-colonial production in which malevolent absence is produced deliberately in mainstream political discourses. Malevolent absence is evident in the purposeful politicisation of Indigenous inauthenticity. It serves to reinforce the invisibility of First Nations peoples and marginalise communities in cities; what Larissa Behrendt, a Eualeyai/Kamillaroi woman, a legal academic and writer, demarcates as the psychological terra nullius that renders invisible Indigenous life projects in cities (Behrendt 2002).

This politics of authenticity has pervaded political, legal, bureaucratic, and popular discourses in nation-states with First Nations peoples, such as Australia, Canada, Aotearoa New Zealand, and the United States. The city is constructed as the definitive conquered space. Indigenous cultures are represented as too fragile to survive in the city. Political discourses in Canada, for example, often portray First Nations peoples as either living in a culture of poverty and enmeshed in cultural conflict or culture is depicted as an 'obstacle to successful adjustments in the city' (Todd 2000, 50). One becomes Indigenous in the city. It is the deeming of First Nations peoples as 'in-authentically' First Nations peoples in cities that continue to connect colonial cultures to contemporary mainstream society (Coyle 
2015). The construction of 'in-authenticity' plays a central role in the facilitation of invisibility (Lucero 2013; Coyle 2015, 606). It entails, for example, the political act of constructing invisibility via epistemic and discursive practices that construct 'urban Indigenous peoples' within a poverty of culture and reduces First Nations organisations to a service delivery function. The distorted image of governments as knowers inhibits the possibility of meaningful dialogue. This form of seeing is one-dimensional - it is seeing through a flat epistemology of whiteness.

It is a simplified and solely spatialised white colonial understanding whereby being authentically Indigenous is associated with remoteness, community, and tradition, static and fixed in time. It is associated with continuing practices and connections to one's homeland and nation, but not with reserves, relocation, or lives in cities. It is western political myopia embedded in our institutions, including our law. Settler-colonial societies not only fail to see First Nations culture as an ontological reality - as being; as existence; as social, relational, and transferable; and as deeply embedded systems of knowledge, rules, and protocols - but they continue to colonise Indigenous culture, box it in, and interpret it through a western epistemological lens of whiteness. This form of cultural 'othering' concerns how settler-colonial societies create, imagine, and construct knowledge about First Nations peoples in cities.

The analysis provided in this book is part of a more comprehensive discussion about how ways of seeing cities and thinking about cities remain deeply racialised (Goldberg 1993, 1997). Cities have long, complex Indigenous and settlercolonial histories (Furlan 2017, 10). Settler-colonial cities have and continue to act as 'contact zones' (Furlan 2017, 10; Pratt 1991). The process of rendering visible also exposes ongoing First Nations peoples' struggles in cities with what Cheryl Harris coined as 'whiteness as property', which is 'jealously guarded as a possession' (Harris 1993, 277, 280). Whiteness as property forms the backdrop for which recognition is framed, argued, and adjudicated (Harris 1993, 277, 280). Visibility exposes the absence of thorough and decolonial reflexivity of the settler-colonial city as a white space. The capacity for Indigenous community development and resurgence is complexly interrelated with a politics structured in the interests of whiteness, capital, and the state in cities (Coulthard in Gardner \& Clancy 2017, 1).

What is original about this book is that it turns attention to the success of Indigenous community development and cultural resurgence in cities.

\section{The urban space void of Indigenous sovereign presence}

It is not the intent of the book to provide what Glen Clouthard describes as an urbs nullius perspective - 'urban space void of Indigenous sovereign presence' (Coulthard 2014, 176). The city of Chicago is the traditional territory of the Potawatomi people. Muloobinba (Newcastle) is the traditional territory of the Awabakal people. The city of Oakland in San Francisco Bay is the traditional territory 
of the Ohlone people. The city of Canberra is the traditional territory of the Ngunnawal and Ngambri people. The city of Gosford is the traditional territory of the Guringai and Darkinjung peoples. The city of Toronto is the traditional territory of many First Nations peoples including the Mississauga of the Credit, the Anishinaabe, the Chippewa, the Haudenosaunee, and the Wendat. Tāmaki (Auckland) is the traditional territory of several $i w i$.

The Potawatomi people, the Ohlone people, the Ngunnawal and Ngambri peoples, the Awabakal people, the Guringai and Darkingjung peoples, the Anishinaabe, the Chippewa, the Haudenosaunee and the Wendat peoples, and the iwi of Tāmaki are First Nations peoples and the sovereign peoples of the land settlercolonial cities occupy. There are settler-colonial cities that are not subject to a treaty and settler-colonial cities that remain unceded territory.

There are First Nations peoples that remain unrecognised under state and federal law in cities in Australia, Canada, and the United States, such as the Muwekma Ohlone people of the San Francisco Bay area. The Ohlone First Nation has more than 500 members and is currently unrecognised under both the state of California and the federal government. The Awabakal people remain unrecognised but had a Native Title claim over Awabakal nation, including Newcastle. They had to withdraw their claim. The state government recognised the claim group as the descendants of the original inhabitants of the land, but the native title processes essentialises its way of seeing and ignores colonisation, finding they were unable to prove they had followed their traditional laws and customs continuously since the time of white settlement. If they pursued this claim in the federal court, they would have no access to federal funding to do so. It goes to the limitations of law, such as Australia's Native Title as it applies to the role settler-colonial cities play in dispossession.

First Nations peoples were dispossessed, relocated from cities to make way for colonisation of the land and city building. After an 18-year battle, the city of Adelaide is now a more inclusive recognition space, but the Kaurna people's rights to the city are contained. Under Native Title, they may get the right to make decisions about the use of the land, to use its resources, and to carry out activities including hunting, fishing, and harvesting of resources.

The life projects of Traditional Owners in cities sit alongside the life projects of First Nations peoples who relocated to cities. Those life projects weave together in complex ways: sometimes together, sometimes taking different journeys, and sometimes in conflict. There are Awabakal First Nations people who relocated back to Newcastle after dispossession, and there are Awabakal First Nations people who remained in the region. There are Awabakal First Nations people who have played an important role in community building and development in Newcastle.

\section{Outline}

You cannot go from here to there without knowing the story. Knowing the story is important because other communities might be able to learn from all the intricacies of that experience, and you could not replicate that anywhere. It 
could also be a way of people thinking 'We have sort of done that, and we could do this. . . . How did everyone work together to achieve that?'

(transcript 2).

The book is a history of the present. Its purpose is to render visible Indigenous resurgence and successful community development in not only the Australian city of Newcastle but also cities in Australia, Canada, Aotearoa New Zealand, and the United States. The goal of this book is to situate an in-depth case study of Newcastle alongside experiences in other cities. The book is organised into two parts. The first part will focus on First Nations peoples' agency in cities in the context of community development and resurgence. That is how 'recognition from below' occurred when First Nations peoples in dominated social positions had the autonomy to shape their own social orders without approval or permission of any authority beyond themselves (Williams 2014, 10). Rights claims were a vehicle for forging new emancipated forms of Indigenous identity, autonomy, and sovereignty in the city.

The struggles, but also the successes, of the Awabakal Cooperative signify those of local Kooris and the struggles and successes of First Nations peoples in cities in Australia and elsewhere. Comparing this history to other localities reveals Indigenous social mobilisation and organisation building as a national and international social phenomenon across Australia, Canada, Aotearoa New Zealand, and the United States. It ensures that readers cannot dismiss 'Indigenous alternatives and community solutions as naively localist, separatist or outmoded' (Coombes et al. 2012, 697). Explaining this history exposes the moments of visibility and invisibility, decolonisation and recolonisation moments in time that reveal how the past and present are so undeniably, inextricably intertwined.

The subject of Chapter 2 is First Nations peoples' relocation to cities. Relocation came on the back of a long history of deliberate initiatives by governments to move First Nations peoples from one location to another. Many came to cities under voluntary relocation programs designed to assimilate and acculturate First Nations peoples into mainstream society. In the United States and Canada, voluntary relocation programs were a solution to Indigenous reservation dependency on governments (Bateman 1997; Silvern 2017). Divergent from widespread mainstream political expectations, First Nations peoples did not 'blend into the landscape of urban anonymity and disappear forever in a faceless crowd of overwhelming numbers' (Moisa 2002, 22).

Post-World War II projects of Indigenous resurgence in cities arose from urban relocation programs and voluntary migration in the four settler states of Australia (Morgan 2006), Canada (Peters \& Andersen 2013; Norris, Clatworthy, \& Peters 2013; Hill \& Cooke 2014), Aotearoa New Zealand (Rosenblatt 2002; Nikora et al. 2004; Ryks et al. 2014, Ryks, Pearson, \& Waa 2016; Keenan 2014; Williams 2015), and the United States (Fixico 1990; Rosenthal 2012; Chudacoff, Smith, \& Baldwin 2016; Pollak 2016). 
Chapter 2 reveals how the city of Newcastle, like the cities of Auckland, Chicago, New York, Sydney, Toronto, and Vancouver, became a place where First Nations peoples migrated to and engaged in the renewal of Indigenous life projects and new visions of the world (Blaser 2004). Some Kooris came to Newcastle under the Families Relocation Program (Guth 1971). Others came to Newcastle because of the apartheid that existed outside cities and the slow relaxing of protections laws. The chapter draws on the relocation narratives of seven Koori Elders. Koori Elders explain how reservation life, and later transience, then a new life in the city did not equate to a loss of culture. First Nations peoples did not give up or rescind connections to their nations of birth or connections with their traditional matrilineal or patrilineal nations. Kooris who relocated to Newcastle maintained strong connections with kin and country in rural localities predominately in the west and northwest of New South Wales - areas with high levels of racism and high unemployment rates. Racialised segregation on missions and reservations had been a way of life for Kooris for nearly a century. Cities offered an escape from the surveillance, monitoring, and poverty of reservations.

While the nuances around events differ, the building of 'communities of association' and Indigenous organisations in settler-colonial cities began with First Nations peoples congregating in meeting places and word soon getting around about the locality of these meeting places. First Nations peoples who relocated from different nations to the cities of Chicago, Minneapolis, Newcastle, Oakland, Phoenix, Sydney, Toronto, and Vancouver came together and organised themselves in a way that they could effectively engage in processes of self-definition, self-advocacy, and self-determination (Beck 2002, 130). Cooperation among different First Nations peoples was central to community building (Beck 2002).

This was the beginning of Indigenous cultural resurgence in settler-colonial cities. Kooris relocating to Newcastle from other First Nations - such as Dunghutti, Gamilaroi, Wonnarua, and Wiradjuri - shared similar knowledge systems, kinship arrangements, ways of doing business, and ways of being in the world. Paul Collis, who spent much of his younger adult years in Newcastle, notes that Kooris also 'carried the land within themselves, rather than walking upon it' (Collis cited in Collis \& Webb 2014, 505). There was a strong desire among Kooris for cultural resurgence and the conscious claiming and naming of an identity (Collis cited in Collis \& Webb 2014, 504). This conscious claiming and naming of identity came from a shared deep epistemological empathy and appreciation of how the imposition of 'Aboriginality' as a socially constructed settler-colonial category had entailed common life experiences across nations and peoples, with colonisation, dispossession, child removal, racism, discrimination, and exclusion from the state. Kooris came together in this city.

The nations in which First Nations peoples in cities live remain engendered with memory and are contested as both territory and sacred site (Furlan 2017, 22). They thus retain not only their political, but also their cultural and spiritual, significance and meaning. First Nations peoples who moved to cities continued to care for the land and all that belonged to it. In Newcastle, the deep, culturally mediated 
association Kooris had to their own nations was extended to Awabakal nation. Kooris who relocated to this city applied the same respectful, relational dynamic of reciprocity to and custodianship for land and place to their new home. They expressed an obligation that came with living on Awabakal country to nation, language, land, and totems, including an obligation to protect the memories and sacred places. Cultural resurgence entailed positive engagement with the broader Newcastle society in negotiating mainstream respect for and providing a space for Indigenous knowledges, protocols, and cultures in all domains of life from service delivery through to community spaces.

It is in this moment that the Awabakal Newcastle Aboriginal Cooperative was formed. The history of the Awabakal Cooperative is not dissimilar to the history of the American Indian Centre in Chicago (La Pier \& Beck 2015), the Phoenix Indian Center (Sage 2016; Martinez 2016), the Vancouver Friendship Centre (Lindsay 1998; Reynolds 2015; Langford 2016), the Manukau Maori Authority (Ryks et al. 2014; Gagne 2013, 2016), and Te Whanau O Waipareira (Barnes 2000; Levine 2001; Rosenblatt 2002; Tamihere 2015; Gagne 2016) in Auckland. Chapter 3 provides a detailed description of the formation of the Awabakal Newcastle Aboriginal Cooperative and its intent. Chapter 3 examines the intention of social movements in terms of the tactical repertoires that they engage to configure Indigenous rights in the city.

The nuances and complexity behind the creation of a loose alliance of community-based First Nations organisations in Newcastle is the focus of Chapter 4. Indigenous organisation-building in cities has not previously been explored or understood. The chapter illustrates how Indigenous entrepreneuring in this city has been directed at restoring and healing Indigenous lifeworlds by addressing the complex economic, racial, social, and cultural disadvantage local Kooris experience in this city. Indigenous culture, ways of doing business, governance, ownership, and control are at the centre of Indigenous community development in Newcastle. Kooris describe Indigenous entrepreneuring as an act or action rather than an entity. Chapter 4 describes how First Nations organisations catalysed cultural resurgence and economic prosperity through the community entrepreneuring of local Kooris and how this led to the formation of a loose alliance of community organisations in Newcastle. Kooris have been engaged in designing innovative culturally centred solutions to meet the needs of local Kooris. This is an example of bottom-up, community-driven and controlled development and entrepreneuring grounded in Indigenous cultural and social norms and ways of doing business.

Chapter 5 lays bare a 20-year Indigenous-led struggle for transformative reconciliation in Newcastle (Borrows \& Tully 2018). While creating self-governance in cities, the greatest struggle has been the one First Nations peoples face with participating in the cultural, social, political, and economic oeuvre of the city. Chapter 5 examines how Kooris who had established much-needed community economic, social, and cultural infrastructure now used reconciliation as a framework for advocating for cultural resurgence, justice, and decolonising the 
relationship between First Nations peoples and the city. The national reconciliation agenda held the seeds for cultural resurgence and exercising an Indigenous right to the city. In 1992, a group of Koori representatives from First Nations organisations drafted the Commitment to First Nations Peoples in the Hunter Region. A local treaty was a key objective, as too was the reinstatement of a visible, marked Awabakal presence in the city. Ten years later, local Kooris led a public inquiry into a treaty - the Hunter Peoples Inquiry into a Treaty. Today, there is still no treaty. Twenty-five years later, local Kooris were still negotiating with local government over reinstating an Awabakal presence in the city. Chapters 5 and 6 make comparative reference to reconciliation in Montreal and Vancouver.

There is a well-worn analytical path of critical Indigenous political theory unpacking the limitations of liberalism and the forms of liberal recognition emanating from the political rationalities and technologies of governmentality of the state in relation to First Nations peoples (Altamirano-Jimenez 2004; Nadasdy 2005; Alfred \& Corntassel 2005; Alfred 2009a, 2009b, 2013; Turner 2006; Coulthard 2007, 2014; Simpson 2014). The last two chapters illustrate how the liberal city offers the guise of reconciliation and recognition, but engagement with the city over significant site protection, land claims, and reconciliation continues to attempt to colonise Indigenous domains in Newcastle and elsewhere. This is the context in which First Nations peoples experience cultural resurgence today (Simpson 2017, 7). First Nation peoples' critique of recognition emanates from experiencing the inhibiting, present-day colonial practices of the city and the state that inhibit First Nations peoples' agency in the present moment under the guise of recognition. The local, state, and federal institutions First Nations peoples interact with continue to not only ignore Indigenous sovereignty and authority but also their ability to act and to be agents, rendering Indigenous knowledge, leadership, and voices effectively silent.

In Chapters 6 and 7, I explore the persistence of the settler-colonial mindset evident in the neoliberal governmentality of the contemporary city and state. Chapters 6 and 7 are concerned with how urban neoliberal transformation and governmentality have affected resurgence, community development, and a right to the city. Chapter 6 examines some of the critical ways that urban neoliberal transformation and governance are not only producing new forms of Indigenous displacement and estrangement among many individuals, whole communities, and 'life spaces' but also are posing new contradictions and creating new struggles in relation to Indigenous resurgence and the exercising of a right to the city. It provides examples of First Nations peoples' struggle around claiming land and place, protecting significant Indigenous sites, and reinstating Awabakal presence in not only Newcastle but also other cities in the neoliberal age to illustrate its point.

Chapter 7 lays bare the profound ways that neoliberal governmentality has changed Indigenous community development, resurgence, and the rights to the city in Newcastle, including the very capacity of First Nations organisations to bring about social change in this city. Chapter 7 gives more detailed consideration 
to neoliberal governmentality as a form of post-welfare state politics that deploys a particular art of governing individual Indigenous disadvantage (Larner 2000, 2004; Lemke 2003; Brown 2003; Dean 2004). The governmentality scholarship illustrates that social projects of the state in the neoliberal age are often highly interventionist and focused on transforming the social welfare sector (HowardWagner 2006). It is the poor and disadvantaged who are the target of neoliberal social projects (Wacquant 2009). It is in this scholarly space that a small body of research exposes how neoliberal social projects can operate as racial projects. This scholarship exposes not only the racialised effects of neoliberal social projects, but it also analyses how race continues to structure social ordering under neoliberalism (Winant 1997, 2004; Goldberg 2009; Wacquant 2009; Soss, Fording, \& Schram 2011). Among this scholarship is an analysis of the specificities of particular social strategies as racial formations in the neoliberal age (HowardWagner 2018). This is articulated at the site of the state because historically it is the state's institutions that have governed, and, as will be demonstrated, continue to govern Indigenous affairs (Howard-Wagner 2018). As I explain elsewhere, scholars in the United States, such as Wacquant (2009), Soss, Fording, and Schram (2011) and Mills (2015), illustrate how neoliberal social strategies in the United States, aimed at addressing a generic form of 'poverty' across the social system, operate as what Michael Omi and Howard Winant (1994) define as racial projects (Howard-Wagner 2018). In doing so, they reveal how neoliberal social strategies have 'a radically disparate impact on different groups because of the past history of racially differentiated and discriminatory treatment' (Mills 2015, 84).

Elsewhere I reveal how governing through Indigenous disadvantage operates as a complex, overt racial project in which Aboriginal and Torres Straits Islander in Australia peoples are invented, constituted, and assimilated into the neoliberal body politic through the positive paternalistic governing of Indigenous socio-economic disadvantage (Howard-Wagner 2018). I argue that, intrinsically, the governing of Aboriginal and Torres Strait Islander peoples through their socio-economic disadvantage is a powerful racial project in which the neoliberal state arbitrates in Indigenous politics and, in fact, reconfigures Indigenous politics (HowardWagner 2018). This began in 1996 with the election of the federal Howard Coalition government that repositioned the rights of Aboriginal and Torres Strait Islander peoples in law and policy (Howard-Wagner 2006). I discuss the effect 'actually existing neoliberalism' (Cahill 2010) has had on community development and self-determination in the city of Newcastle.

In Australia, there has been little room for First Nations peoples to move politically (even within the politics of poverty governance) in terms of overcoming Indigenous disadvantage. The concluding chapter reflects on the wilful inattentiveness to the durability of racial inequality in settler nation-states in the present moment. It centres this analysis around the consideration of the Black Lives Matters protests, which drive home the legacies of colonialism and racialised harm in cities. 


\section{Notes}

1 The terms Aboriginal peoples, Indigenous peoples, and First Nations peoples have come to take on different meanings to different people in different nation states. There is not a unanimous view on which terms should be used. I use the term First Nations peoples instead of Aboriginal peoples or Indigenous peoples to reinforce one of the key arguments of the book. I often use the term Koori in reference to First Nations peoples in Newcastle as it is the most widely used term in that city. It refers to First Nations peoples from New South Wales. I use the term Indigenous to refer to laws, policies, structures, practices and epistemologies.

2 The number of Aboriginal and Torres Strait Islander people living in Carrington and Mayfield is equivalent to the numbers in recognised communities across the Awabakal nation in the Lake Macquarie local government area, such as Toronto $(7.1 \%, \mathrm{n}=395)$, Glendale $(6.5 \%, \mathrm{n}=203)$, and West Wallsend $(5.8 \%, \mathrm{n}=131)$.

3 From 1804 to 1821, Newcastle was a penal settlement, which prevented large land grants in the area (Brayshaw 1986). Awabakal people initially co-existed with the settlement on the Coquun (Hunter) River.

\section{References}

Ahmet, R (2001). 'Taking Back Responsibility and Restoring Aboriginal Capacity in Cape York Peninsula', Opening address to the Northern Summit 11 September, Cape York Partnerships.

Alfred, G T (2009a). Peace, Power, Righteousness: An Indigenous Manifesto, 2nd Edition. Oxford: Oxford University Press.

Alfred, G T (2009b). 'Colonialism and State Dependency', International Journal of Indigenous Health, Vol. 5, No. 2, pp. 42-60.

Alfred, G T (2013). 'Being and Becoming Indigenous: Resurgence Against Contemporary Colonialism', in 2013 Narrm Oration. Melbourne: Murrup Barak, Melbourne Institute for Indigenous Development at the University of Melbourne.

Alfred, G T \& Corntassel, J (2005). 'Being Indigenous: Resurgences Against Contemporary Colonialism', Government and Opposition, Vol. 40, No. 4, pp. 597-614.

Altamirano-Jimenez, I (2004). 'North American First Peoples: Slipping into Market Citizenship?' Citizenship Studies, Vol. 8, No. 4, pp. 349-365.

Australian Bureau of Statistics (ABS) (2016). '2016 Census Quickstats', http://quickstats. censusdata.abs.gov.au/census_services/getproduct/census/2016/quickstat/.

Awabakal Ltd (2016). 'History', www.awabakal.org/our-past-and-future/history-video.

Awabakal Traditional Owners Aboriginal Corporation (2014). Inquiry into Planning Process in Newcastle and the Broader Hunter Region Submission No 151 Awabakal Traditional Owners Aboriginal Corporation, 23 October 2014.

Bargh, M (2007). 'Maori Development and Neoliberalism', in Resistance: An Indigenous Response to Neoliberalism. Wellington: Huia Publishers, pp. 25-44.

Bargh, M \& Otter, J (2009). 'Progressive Spaces of Neoliberalism in Aotearoa: A Genealogy and Critique', Asia Pacific Viewpoint, Vol. 50, No. 2, pp. 154-165.

Barnes, H M (2000). 'Kaupapa Maori: Explaining the Ordinary', Pacific Health Dialog, Vol. 7, No. 1, pp. 13-16.

Bateman, R (1997). 'Comparative Thoughts on the Politics of Aboriginal Assimilation', BC Studies: The British Columbian Quarterly, No. 114, pp. 59-83. 
Beck, D R (2002). 'Developing a Voice: The Evolution of Self-Determination in an Urban Indian Community', Wicazo Sa Review, Vol. 17, No. 2, pp. 117-141.

Behrendt, L (2002). 'Mabo Ten Years on: A Psychological Terra Nullius Remains', Impact, Vol. 1, pp. 8-9.

Birch, T (2005). 'Death Is Forgotten in Victory': Colonial Landscapes and Narratives of Emptiness', in Lydon, J \& Ireland, T (eds.), Object Lessons: Archaeology and Heritage in Australia, pp. 186-200. Melbourne: Australian Scholarly Publishing.

Blaser, M (2004). 'Life Projects: First Nations Peoples' Agency and Development', in Blaser, M, Feit, H \& McRae, G (eds.), In the Way of Development: First Nations Peoples, Life Projects and Globalization. London: ZED Books, pp. 23-43.

Borrows, J \& Tully, J (2018). 'Introduction', in Asch, M, Borrows, J \& Tully, J (eds.), Resurgence and Reconciliation: Indigenous-Settler Relations and Earth Teachings. Toronto: University of Toronto Press.

Brayshaw, H (1986). Aborigines of the Hunter Valley: A Study of Colonial Records. Scone, NSW: Scone \& Upper Hunter Historical Society.

Brown, W (2003). 'Neo-Liberalism and the End of Liberal Democracy', Theory and Event, Vol. 7, No. 1, http://muse.jhu.edu/journals/theory and_event/v007/7.1brown.html, accessed 26 February 2005.

Cahill, D (2010). “"Actually Existing Neoliberalism” and the Global Economic Crisis', Labour \& Industry: A Journal of the Social and Economic Relations of Work, Vol. 20, No. 3, pp. 298-316.

Chudacoff, H, Smith, J \& Baldwin, P (2016). The Evolution of American Urban History, 8th Edition. New York: Routledge.

Collis, P \& Webb, J (2014). 'The Visible and the Invisible: Legacies of Violence in Contemporary Australian Aboriginal Contexts', Journal of Australian Studies, 38(4), pp. 490-503.

Connolly, C (2018). 'The True Native New Yorkers Can Never Truly Reclaim Their Homeland', The Smithsonian Magazine, 5 October, www.smithsonianmag.com/history/ true-native-new-yorkers-can-never-truly-reclaim-their-homeland-180970472/, accessed 27 September 2019.

Coombes, B et al. (2012). 'Indigenous Geographies II: The Aspirational Spaces in Postcolonial Politics - Reconciliation, Belonging and Social Provision', Progress in Human Geography, Vol. 37, No. 5, pp. 691-700.

Coulthard, G (2007). 'Subjects of Empire: First Nations Peoples and the "Politics of Recognition" in Canada', Contemporary Political Theory, Vol. 6, No. 4, pp. 437-460.

Coulthard, G (2014). Red Skin, White Masks: Rejecting the Colonial Politics of Recognition. Minneapolis, MN: University of Minnesota Press.

Coulthard, G \& Simpson, L B (2016). 'Grounded Normativity/Place-Based Solidarity', American Quarterly, Vol. 68, No. 2, pp. 249-255.

Coyle, J (2015). 'Where Are All the Koori Football Players? The AFL and the Invisible Presence of Indigenous Victorians', Sport in Society, Vol. 18, No. 5, pp. 604-613.

Dahl, J (2012). The Indigenous Space and Marginalized Peoples in the United Nations. New York: Palgrave Macmillan.

Dean, M (2004). Governmentality: Power and Rule in Modern Society. London: Sage Publications.

Elliott, M (2018). 'Indigenous Resurgence: The Drive for Renewed Engagement and Reciprocity in the Turn Away from the State', Canadian Journal of Political Science/Revue canadienne de science politique, Vol. 51, No. 1, pp. 61-81. 
Ellison, R (1952). Invisible Man. New York: Penguin Random House.

Fixico, D (1990). Termination and Relocation: Federal Indian Policy, 1945-1960. Albuquerque, NM: University of New Mexico Press.

Furlan, L M (2017). Indigenous Cities: Urban Indian Fiction and the Histories of Relocation. Nebraska: University of Nebraska Press.

Gagne, N (2013). Being Māori in the City: Indigenous Everyday Life in Auckland. Toronto: University of Toronto Press.

Gagne, N (2016). 'The Waxing and Waning of the Politics of Authenticity: The Situation of Urban-Based Māori Through the Lens of Municipal Politics', City \& Society, Vol. 28, No. 1, pp. 48-73.

Gardner, K \& Clancy, D (2017). 'From Recognition to Decolonization: An Interview with Glen Coulthard', Upping The Anti, No. 19, September, http://uppingtheanti.org/journal/ article/19-from-recogntion-to-decolonization/.

Goldberg, D T (1993). Racist Culture: Philosophy and the Politics of Meaning. Oxford: Wiley-Blackwell.

Goldberg, D T (1997). Racial Subjects: Writing on Race in America. New York: Psychology Press.

Goldberg, D T (2009). The Threat of Race: Reflections on Racial Neoliberalism. Malden, MA: Wiley-Blackwell.

Goldberg, D T (2017). Multiculturalism: A Critical Reader. Cambridge, MA: WileyBlackwell.

Guth, S O (1971). Interim Report: Newcastle Aborigine Research Project. Armidale: The University of New England.

Harris, C I (1993). 'Whiteness as Property', Harvard Law Review, Vol. 106, No. 8, pp. 1707-1791.

Harris, M (2015). 'Heritage Dig Uncovers Artefacts', Newcastle Herald, 28 August.

Havemann, P (1999). First Nations People's Rights in Australia, Canada and New Zealand. Oxford: Oxford University Press.

Heritz, J (2013). 'Urban Aboriginal Self-Determination in Toronto', in Newhouse, D et al. (eds.), Well-Being in the Urban Aboriginal Community: Fostering Biimaadiziwin. Toronto: Thompson Educational Publishers.

Hill, G \& Cooke, M (2014). 'How Do You Build a Community? Developing Community Capacity and Social Capital in an Urban Aboriginal Setting', Pimatisiwin, Vol. 11, No. 3, pp. 421-432.

Howard-Wagner, D (2006). Post Indigenous Rights: The Political Rationalities and Technologies Governing Federal Indigenous Affairs in Australia in the Contemporary Period. Doctoral Dissertation, University of Newcastle, Newcastle.

Howard-Wagner, D (2017). 'Successful Urban Aboriginal-Driven Community Development: A Place-Based Study of Newcastle', CAEPR Discussion Paper.

Howard-Wagner, D (2018). 'Governance of Indigenous Policy in the Neo-Liberal Age: Indigenous Disadvantage and the Intersecting of Paternalism and Neo-Liberalism as a Racial Project', Ethnic and Racial Studies, Vol. 41, pp. 1132-1151.

Howard-Wagner, D, Bargh, M \& Altamirano-Jimenez, I (2018). 'From New Paternalism to New Imaginings of Possibilities in Australia, Canada and Aotearoa/New Zealand: Indigenous Rights and Recognition and the State in the Neoliberal Age', in HowardWagner, D, Bargh, M \& Altamirano-Jiménez, I (eds.), The Neoliberal State, Recognition and Indigenous Rights: New Paternalism to New Imaginings. Canberra: ANU Press. 
Keenan, S (2014). 'Moments of Decolonization: Indigenous Australia in the Here and Now', Canadian Journal of Law and Society, Vol. 29, No. 2, pp. 163-180.

Keith, M \& Cross, M (1993). 'Racism and the Postmodern City', in Cross, M \& Keith, M (eds.), Racism, the City and the State. Abingdon: Routledge.

La Pier, R \& Beck, D (2015). City Indian: Native American Activism in Chicago, 18931934. Lincoln and London: University of Nebraska Press.

Langford, W (2016). 'Friendship Centres in Canada, 1959-1977', American Indian Quarterly, Vol. 40, No. 1, pp. 1-37.

Langton, M (2012). 'Indigenous Exceptionalism and the Constitutional "Race Power", Melbourne Writers Festival, BMW Edge Theatre, Federation Square, Melbourne, Space Place Culture, Vol. 26, pp. 1-20.

Larner, W (2000). 'Neo-Liberalism: Policy, Ideology, Governmentality', Studies in Political Economy, No. 63, Autumn, pp. 5-25.

Larner, W (2004). 'Neoliberalism in (Regional) Theory and Practice: The Stronger Communities Action Fund', Research Paper No. 14, Local Partnerships and Governance Group, New Zealand.

Latimore, J (2018). 'First Nations Peoples Are Being Displaced Again - by Gentrification', The Guardian, 9 April, www.theguardian.com/cities/2018/apr/09/indigenous-peopleare-being-displaced-again-by-gentrification-aboriginal-redfern-west-end-fitzroy.

Lee, W (2016). 'American Indian Center Prepares to Move Out of Uptown, Marking End of Era', The Chicago Tribune, 27 November.

Lemke, T (2003). 'Comment on Nancy Fraser: Rereading Foucault in the Shadow of Globalisation', Constellations, Vol. 10, No. 2, pp. 172-179.

Levine, H B (2001). 'Can a Voluntary Organisation Be a Treaty Partner? The Case of the Whanau O Waipareira Trust', Social Policy Journal of New Zealand, Vol. 17, pp. 161-170.

Levine, L (2018). 'Mapping Manahatta: 10 Lenape Sites in New York City, Posted on 6sqft', Tue, 20 November, www.6sqft.com/mapping-manahatta-10-lenape-sites-in-newyork-city/, accessed 26 September 2019.

Lindsay, W G (1998). A History of the Vancouver Aboriginal Friendship Centre in an Age of Aboriginal Migration and Urbanization. Masters Dissertation, UBC Press, Vancouver.

Lobo, S (2016). Native American Voices, 3rd Edition. New York: Routledge.

Lucero, N (2013). 'Being Indian in the City: Generational Differences in Negotiation of Native Identity Among Urban Based American Indians', in Andersen, C and Peters, E (eds.), Indigenous in the City: Contemporary Identities and Cultural Innovation. Vancouver: UBC Press, pp. 193-215.

McElroy, J (2017). 'Who Owns This City? Why Debates Around Vancouver Place Names Are Divisive', $C B C$ News, www.cbc.ca/news/canada/british-columbia/sign-namechanging-vancouver-oct-2017-1.4342822, accessed 10 September 2019.

Martinez, D (2016). 'Building an Urban Rez: American Indian Intertribal Organizations in the Twentieth Century', in Martinez, D, Sage, G \& Ono, A (eds.), Urban American Indians: Reclaiming Native Space, pp. 63-84.

Meade, R R (2018). 'The Re-Signification of State-Funded Community Development in Ireland: A Problem of Austerity and Neoliberal Government', Critical Social Policy, Vol. 38, No. 2, pp. 222-243.

Miller, J (1985). Koori: A Will to Win. Sydney: Angus \& Robertson. 
Mills, C W (2015). 'Piercing the Veil', in Watson, V, Howard-Wagner, D \& Spanierman, L (eds.), Unveiling Whiteness in the Twenty-First Century: Global Manifestations, Transdisciplinary Interventions. Lanham, MD: Lexington Books, pp. 77-88.

Moisa, R (2002). 'Relocation: The Promise and the Lie', in Lobo, S (ed.), Urban Voices: The Bay Area American Indian community. Intertribal Friendship House (Oakland, California). Community History Project, Tucson: University of Arizona Press.

Moreton-Robinson, A (2008). 'Writing off Treaties: White Possession in the United States', in Moreton-Robinson, A, Casey, M \& Nicoll, F (eds.), Transnational Whiteness Matters. Plymouth: Lexington Books, pp. 81-96.

Morgan, G (2006). Unsettled Places: Aboriginal People and Urbanisation in New South Wales. Adelaide: Wakefield Press.

Nadasdy, P (2005). Hunters and Bureaucrats: Power, Knowledge, and Aboriginal-State Relations in the Southwest Yukon. Vancouver: UBC Press.

Newhouse, D R (2003). 'The Invisible Infrastructure: Urban Aboriginal Institutions and Organizations', in Newhouse, D \& Peters, E (eds.), Not Strangers in These Parts: Urban Aboriginal Peoples. Ottawa: Policy Research Initiative, pp. 243-253.

Newhouse, D R \& Peters, E (2003). 'Introduction', in Newhouse, D \& Peters, E (eds.), Not Strangers in These Parts: Urban Aboriginal Peoples. Ottawa: Policy Research Initiative.

Nikora, L et al. (2004). 'Indigenous Psychologies Globally - A perspective from Aotearoa/ New Zealand', www.researchgate.net/publication/33051133_Indigenous_psychologies_ globally_a_perspective_from_AotearoaNew_Zealand.

Norris, M J, Clatworthy, S \& Peters, E (2013). 'The Urbanization of Aboriginal Populations in Canada: A Half Century in Review', in Peters, E \& Andersen, C (eds.), Indigenous in the City: Contemporary Identities and Cultural Innovation. Vancouver: UBC Press, pp. 29-45.

Omi, M \& Winant, H (1994). Racial Formation in the United States, 2nd Edition. New York: Routledge and Kegan Paul.

Peredo, A M \& Chrisman, J J (2010). 'Toward a Theory of Community-Based Enterprise', The Academy of Management Review, Vol. 31, No. 2, pp. 309-328.

Peters, E \& Andersen, C (2013). Indigenous in the City: Contemporary Identities and Cultural Innovation. Vancouver: UBC Press.

Petray, T L (2010). Actions, Reactions, Interactions: The Townsville Aboriginal Movement and the Australian State. PhD Thesis, James Cook University, Australia.

Petray, T L (2012). 'Can Theory Disempower? Making Space for Agency in Theories of Indigenous Issues', Theorising Indigenous Sociology: Australian Perspectives Workshop Proceedings. From: Theorising Indigenous Sociology: Australian Perspectives Workshop, 22-29 November 2012, Brisbane, QLD, Australia, pp. 1-6.

Pollak, M (2016). 'Reflection on Urban Migration', American Indian Culture and Research Journal, Vol. 40, No. 3, pp. 85-102.

Pratt, M L (1991). 'Arts of the Contact Zone', Profession, pp. 33-40.

Putnam, R D \& Feldstein, L M (2003). Better Together: Restoring the American Community. New York: Simon \& Schuster.

Razack, S (2014). " "It Happened More Than Once": Freezing Deaths in Saskatchewan', Canadian Journal of Women and the Law, Vol. 26, No. 1, pp. 51-80.

Reynolds, L (2015). Transformative Planning Practice and Urban Indigenous Governance in Vancouver, British Columbia. Vancouver: Simon Fraser University. 
Rosenblatt, D (2002). 'Titirangi Is the Mountain: Representing Maori Community in Auckland', Pacific Studies, Vol. 25, No. 1, pp. 117-140.

Rosenthal, N G (2012). Reimagining Indian Country: Native American Migration and Identity in Twentieth-Century Los Angeles. Chapel Hill: University of North Carolina Press.

Ryks, J, Howden-Chapman, P, Robson, B, Stuart, K \& Waa, A (2014). 'Maori Participation in Urban Development: Challenges and Opportunities for First Nations Peoples in Aotearoa New Zealand', Lincoln Planning Review, Vol. 6, No. 1-2, pp. 4-17.

Ryks, J, Pearson, A L \& Waa, A (2016). 'Mapping Urban Māori: A Population-Based Study of Māori Heterogeneity’, New Zealand Geographer, Vol. 72, No. 1, pp.28-40.

Sage, G (2016). 'Building Relationships and Mapping Community in the Urban Environment', in Martinez, D, Sage, G \& Ono, A (eds.), Urban American Indians: Reclaiming Native Space. Santa Barbara: Praeger.

Shaw, W (2007). Cities of Whiteness. London: Wiley-Blackwell.

Shoebridge, D (2011). 'Kentucky Fried Chicken Destroys Aboriginal Heritage Site', 27 May, https://davidshoebridge.org.au/2011/05/27/kentucky-fried-chicken-destroys-aboriginalheritage-site/, accessed March 2013.

Silvern, S (2017). 'Native American Resurgence and Scales of Identity', in Gerb, G H \& Kaplan, D H (eds.), Scaling Identities: Nationalism and Territoriality. Lanham, MD: Rowman \& Littlefield, pp. 159-184.

Simpson, A (2014). Mohawk Interruptus; Political Life Across the Borders of Settler States. London: Duke University Press.

Simpson, L B (2011). Dancing on Our Turtle's Back: Stories of Nishnaabeg Re-Creation, Resurgence, and a New Emergence. Winnipeg, MB: Arbeiter Ring Publishing.

Simpson, L B (2017). As We Have Always Done: Indigenous Freedom Through Radical Resistance. Minneapolis, MN: University of Minnesota Press.

Smee, B (2011). 'KFC Aboriginal Artefact Loss an Act of "Genocide"', Newcastle Herald, 22 May.

Smith, D (2008). 'The Business of Governing: Institutional Capital in an Urban Enterprise', in Hunt, J, Smith, D, Garling, S \& Sanders, W (eds.), Contested Governance: Culture Power and Institutions in Indigenous Australia. Canberra: CAEPR Monograph, ANU Press.

Soss, J, Fording, R C \& Schram, S F (2011). Disciplining the Poor: Neoliberal Paternalism and the Persistent Power of Race. Chicago: The University of Chicago Press.

Tamihere, C (2015). "Kōkiritia i roto i te kotahitanga": A Process Evaluation of a Wraparound Programme at Te Whānau o Waipareira Trust. Doctoral Dissertation, ResearchSpace@Auckland.

Tatz, C M (2003). With Intent to Destroy: Reflecting on Genocide. London: Verso.

Todd, R (2000-2001). 'Between the Land and the City: Aboriginal Agency, Culture and Governance in Urban Areas', The London Journal of Canadian Studies, Vol. 16, pp. 49-67.

Tomiak, J (2016). 'Navigating the Contradictions of the Shadow State: The Assembly of First Nations, State Funding, and Scaled of Indigenous Resistance', Studies in Political Economy: A Socialist Review, Vol. 97, No. 3, pp. 217-233. Wacquant, L (2009). Punishing the Poor: The Neoliberal Government of Social Insecurity. Durham, NC: Duke University Press. 
Wacquant, L (2010). 'Crafting the Neoliberal State: Workfare, Prisonfare, and Social Insecurity', Sociological Forum, Vol. 25, No. 2, pp. 197-220.

Walter, M (2009). 'An Economy of Poverty? Power and the Domain of Aboriginality', International Journal of Critical Indigenous Studies, Vol. 2, No. 1, pp. 2-14.

Williams, M (2014). 'Introduction - On the Use and Abuse of Recognition in Politics', in A Eisenberg, J Webber, G Coulthard \& A Boisselle (eds.), Recognition Versus SelfDetermination - Dilemmas of Emancipatory Politics. Vancouver: UBC Press, pp. 3-20.

Williams, M M (2015). Panguru and the City: Kāinga tahi, kāinga rua: An Urban Migration History. Wellington: Bridget Williams Books.

Winant, H (1994). Racial Conditions: Politics, Theory, Comparisons. Minneapolis, MN: University of Minnesota Press.

Winant, H (1997). 'Racial Dualism at Century's End', in Lubiano, W (ed.), The House That Race Built. New York: Random House, pp. 87-115.

Winant, H (2004). 'Behind Blue Eyes: Whiteness and Contemporary US Racial Politics', Off White: Readings on Power, Privilege, and Resistance, Vol. 2, pp. 3-16.

Yashar, D J (1999). 'Democracy, Indigenous Movements, and the Postliberal Challenge in Latin America', World Politics, Vol. 52, No. 1, pp. 76-104.

Yashar, D J (2005). Contesting Citizenship in Latin America: The Rise of Indigenous Movements and the Postliberal Challenge. Cambridge: Cambridge University Press. 


\title{
Settler-colonial cities as sites of Indigenous relocation
}

\author{
From removal to relocation
}

Indigenous urbanisation was a federal policy encouraged in the period postWorld War II in the British settler-colonial nations of Australia (Morgan 2006), Canada (Peters \& Andersen 2013; Norris, Clatworthy, \& Peters 2013; Hill \& Cooke 2014), Aotearoa New Zealand (Rosenblatt 2002; Nikora et al. 2004; Ryks et al. 2014, 2016; Keenan 2014; Williams 2015), and the United States (Fixico 1990; Rosenthal 2012; Chudacoff, Smith, \& Baldwin 2016; Pollak 2016). In Australia and Canada, the majority of First Nations peoples who relocated to cities did so of their own accord. Cities offered an escape from the surveillance, monitoring, and poverty of reservations. Still, the 1950s to the 1970s was particular in time in Australia, Canada, and the United States in which forms of accelerated Indigenous relocation to cities occurred. The Urban Indian Relocation Program began in the United States in 1954. The Indian Placement and Relocation Program began in Canada in 1957. The federally funded Indigenous Family Resettlement Scheme began in the Australian State of New South Wales in 1971. The policy intent of voluntary and forced relocation was to assimilate First Nations people socially, culturally, and economically into mainstream settler-colonial societies (Weaver 2012, 472). First Nations peoples were encouraged to lead middle-class lives and shed many parts of their cultural identity in cities (Newhouse \& Fitzmaurice 2012, xi).

Relocation programs and migration saw populations of First Nations peoples increase quickly in the cities of Australia, Canada, Aotearoa New Zealand, and the United States. Benevolence aside, social engineering was at the centre of urban relocation programs. The majority of First Nations peoples who moved to the cities of Chicago, Denver, Los Angeles, Minneapolis, San Francisco, San Jose, St. Louis, Cincinnati, Cleveland, and Dallas in the United States did so under the Urban Indian Relocation Program. The United States federal government had dissolved federal recognition of nearly all tribes. It withdrew federal reservations funding, which had funded reservation schools, hospitals, and other essential services that had also provided employment.

Relocation was a significant moment. Relocation did not lead to assimilation but saw settler-colonial cities become significant sites of Indigenous resurgence. A powerful First Nations account of how the urban space became a space of 
resurgence, and one that challenges taken-for-granted assumptions about Indigenous identities in the city, is that of Apache, Osage, and Cherokee woman, Laura Furlan. In her book Indigenous Cities: Urban Indian Fiction and the Histories of Relocation, Furlan explores the texts of American Indian writers, which she describes as urban Indigenous literature about the American cities in the relocation era. In the context of the United States, Furlan points out that 'taken together these texts demonstrate an arc that radiates from the relocation era through Alcatraz and other political actions of the 1970 s, the identity politics of the 1980 s, concerns about citizenship and federal recognition in the 1990s, and negotiations of nation and nationhood that continue in the present' (Furlan 2017, 9).

Furlan observes 'a radical shift in the often-discussed people and place, a shift in Indian identity - in the way that people think about themselves' associated with relocation (Furlan 2017, 8). Furlan applies her observations to challenge what she considers the perception of First Nations peoples as a 'rooted people' and 'a rooted subjectivity [that] stems from narratives constructed around the relationship between Indians and place' (Furlan 2017, 8). Furlan articulates well an Indigenous experience that is not unique to First Nations peoples living off-nation in urban areas of the United States. It is the experience of First Nations peoples who relocated to the settler-colonial cities across all four settler-colonial states. It is Furlan's observation that First Nations peoples who relocated to cities 'carry with them their connections to their homeland, ties of tradition and kinship, but they also create new diasporic communities in the cities, complicating what it means to be [Indigenous]' (Furlan 2017, 9). The texts Furlan analyses provide an alternative way of seeing First Nations peoples who relocated to the city. Furlan explains how relocation narratives 'highlight communities in cities' and 'a kind of tribal cosmopolitanism as a replacement for a more rooted tribal subjectivity' (Furlan 2017, 9). Relocation narratives renarrate US history (Furlan 2017, 9).

Furlan points to the significance of the relocation period in the US as a turning point in history - as a 'period of rupture' (Furlan 2017, 10). The relocation period is an example of what sociologist Stephen Cornell refers to as a 'critical narrative site' as 'events or sequences that carry rare emotional power for group members and, as critical moments in their version of their story, [that] shape the tale that they tell' (Cornell 2000a, 2000b cited in Furlan 2017, 14). This 'period of rupture' is not unique to the United States but occurred in Australia and Canada, too, and later Aotearoa.

Relocation is the subject of Chapter 2. While relocation entailed further Indigenous dispossession and loss, it is a turning point in the settler-colonial history of cities as places of dispossession. Relocation saw a gradual uprising of Indigenous resurgence in settler-colonial cities. Indigenous resurgence came out of this moment. The chapter contextualises the realities of First Nations peoples relocating to the city of Newcastle as a process that involved the relocation of life projects to cities.

What happened next in Newcastle has many parallels with what happened in Auckland, Brisbane, Chicago, Los Angeles, Melbourne, Minneapolis, New York, 
Oakland, Phoenix, Sydney, Toronto, and Vancouver (Lobo 2002; Peters 2002; Barcham 2004; Williams 2015; Furlan 2017). Kooris who relocated to Newcastle came to pursue interests, aspirations, needs, goals, and objectives offered within the urban landscape, resulting in strong and diverse Indigenous identities existing in Newcastle (Newhouse \& Peters 2003, 10). First Nations peoples' resurgence in this urban context occurs from settler colonisation and dispossession. While there are variations in events, it is the life story of many local Koori Elders in Newcastle.

\section{The invisible histories of Indigenous cities}

Settler-colonial cities are ontologically distinct from colonial cities - the settler colonists came to stay, and colonisation entailed explicit forms of First Nations peoples' territorial alienation (Wolfe 2006; Hugill 2017). The history of settler colonisation development in cities has entailed the 'deterritorialisation of First Nations peoples' (Tomiak 2013, 2-3). As Julie Tomiak reminds us, settlercolonists pursued a diverse range of expulsive tactics from denying Indigenous Title and the entrenchment of a private property system to the creation of a network of reserves and/or missions (Tomiak 2013, 2-3).

The Black Hawk War of 1832 and the 1833 Treaty of Chicago saw First Nations peoples forced out of the area around Chicago (McMullen 1997, 37; Keating 2012). The Potawatomi were forced to walk thousands of miles from their traditional lands of the western Great Lakes in Michigan to the foreign lands of the Prairies of Oklahoma in the United States, making way for the settler city building of Chicago (McMullen 1997). The Potawatomi First Nations people, the Ohlone First Nations people, and the Awabakal First Nations people were dispossessed from their nations to make way for the settler-colonial enterprise of building what are now known as the cities of Chicago, Oakland, and Newcastle.

While there is a level of acknowledgement of the settler-colonial projects of British settler-colonial nations, the history of settler-colonial cities and city building has often been hidden in what Hugill and others describe as 'a mantle of colonial amnesia ... rather than spaces of conquest, eviction, and resettlement' (Hugill 2017, 5). Settler-colonial narratives are purposeful in their rendering invisible Indigenous histories, which allow for their own relocation and the making of new settler-colonial homelands. There is a single-mindedness in depicting the dying out of First Nations peoples in cities as a result of the settlercolonial project. There is an intent to rendering invisible the Indigenous histories of cities. There is a reason for wilfully ignoring settler-colonial cities as Indigenous cities. The object of settler-colonial narratives is to eliminate Indigenous histories and construct settler-colonial cities as relocated and transformed British homelands bonded to the British nation. It is for this reason that the effects of settler colonialism continue to reverberate today in possessive investment in settler-colonial whiteness that is threatened by a return home and Indigenous claims to the city. 
In 1804, what was to become the Australian city of Newcastle, which is two hours north of Sydney, became a harsh penal colony for convict recidivists who worked on extracting coal from the banks of the Coquun (Hunter) River. The region was already occupied. The Awabakal First Nation people occupied what later came to be known as the Newcastle region on the southern side of Coquun River. The Worimi First Nation people occupied the northern side of the Coquun River. The Awabakal people initially co-existed with the penal settlement established on the southern side of the Coquun River until the 1820s. Newcastle's status as a penal settlement prevented large land grants in the area (Brayshaw 1986). In 1826, the first mission in Australia was set up by Reverend Threlkeld on what is now known as the historical Gunya Hotel site at Belmont - a gathering place for Awabakal people - almost 20 kilometres south of Newcastle (Carey 2010; Johnston 2012; Keary 2009). While still on country, the Awabakal First Nation people were gathered up and contained within the site of the mission. The Awabakal First Nation people's language was documented and published by Reverend Threlkeld in 1827, making it the first First Nations language to be written down (Threlkeld 1834). In successive years, as the land of the Bahtabah mission too became valuable, the Awabakal First Nations people were displaced and dispersed, and this is documented as resulting in a rapid decrease in numbers (Threlkeld 1834).

Similar to many other stories about the decline of First Nations peoples, smallpox, dispossession, and violent conflict led to a significant decrease in the number of Awabakal people in the Hunter region during the 1800s (Blyton 1995; Roberts 2008). Worimi First Nations scholar Professor John Maynard provides a compelling but distressing account of the history of massacres, brutality, and horrific experiences of the Awabakal First Nations people during the invasion of Awabakal nation (Maynard 2001). The settler-colonial establishment enacted various horrific acts and did not consider that it was they who were in fact, trespassing and violating Indigenous land tenure (Maynard 2001, 255). Maynard recounts Reverend Threlkeld's story of an Awabakal First Nation man who 'was shot while attempting to steal some corn' (Threlkeld in Maynard 2001, 254). He notes that 'The farmer, in an attempt to dissuade other First Nation people from theft, hung the body from a branch of a nearby tree with a corn cob stuck in the lifeless mouth. It was a case of using a human scarecrow' (Threlkeld in Maynard 2001, 254).

While the logic was elimination and settler-colonists believed that the Awabakal First Nations peoples were eliminated, historical evidence shows this not to be the case. There were Awabakal First Nation people who ended up on the Karuah Mission on Worimi nation a short distance from Awabakal nation. There were Awabakal First Nations people relocated further south and north. Indigenous historian and Worimi woman Victoria Grieves details the movements of Queen Margaret, who was born at Bahtabah mission and briefly relocated to Norah Head on Guringai nation, which is 35 kilometres south on what is now known as the Central Coast. She lived on or on the fringes of Awabakal nation throughout her lifetime (1827-1894) (Grieves 2002). Queen Margaret and her husband King Ned, as well as their children Ellen and William Henry, had a reserve set aside for 
them in 1871, which is now known as Black Ned's Bay (Grieves 2002). Queen Margaret's children and her children's children remained on Awabakal nation. Aunty Nola Hawken is a descendant of Queen Margaret of the Awabakal people. Queen Margaret and King Ned as they are known in historical documents are Aunty Nola's great-great grandparents, and her relationship to them is through her mother, Thelma Powell; her father, Billy Williams; and his mother, Ellen, the daughter of Ned and Margaret.

During the 19th century, the First Nations peoples of New South Wales were gathered up and moved onto reserves and missions contained within smaller parcels of traditional land or removed from their traditional land onto reserves and missions located on the traditional land of neighbouring allies or rivals. Racialised segregation on missions and reserves was becoming a way of life for First Nations peoples. This occurred until the post-World War II period. The state funded an assortment of tightly regulated missions and reserves. Reserves and missions served the purpose of detribalisation. As Blake notes, while 'the reserve system had a profound impact on First Nations peoples ... it did not leave them hapless victims, cultureless or bereft of identity' (Blake 2001, 244).

Australian statute law contributed significantly to the institutionalisation of settler-colonial norms (Russell 2005; Rifkin 2009; Morgensen 2011), operating as a formal mechanism for curtailing the power of First Nations peoples to make decisions in relation to place and land, for example. The issues of land appropriation and racialisation converged in the laws of Australia's newly formed state of New South Wales, as it did in the other federated states and territories of Australia (Banivanua \& Edwards 2010). The authoring of the NSW Aborigines Protection Act of 1909 served such ends. The NSW Protection Act provided for the political and economic domination of the First Nations peoples of New South Wales and their incarceration into a permanent 'state of exception' (Agamben 2005) on reserves and missions, which allowed for the securing of land for colonial settlement and economic expansion. Those on managed reserves were educated and trained in Christianity. Those on unmanaged reserves were only provided rations and came under the control of the police. In the 1950s and 1960s, First Nations peoples were moved of these reserves onto even smaller reserves on the edge of townships and the original areas of reserve land allocated to First Nations peoples were revoked.

The regulated and controlled environment of reserves and missions sought to produce dependent peoples whose affairs and every decision were managed by state-appointed 'Aboriginal protection officers' and administrators under Protection laws. Protection facilitated the settler-colonial preoccupation with subjugation, regulation, and discipline. With Indigenous autonomy and interests erased from the settler-colonial imagination, the ongoing behavioural manifestations of autonomous Indigenous living systems were now constructed in terms of deviance from the norms of the white settler-colonial population. From within this regime of truth, the persistence of distinctly Indigenous ways of life, and the development of strategies in what Scott (2009) has termed 'the art of not being governed', were 
perceived as an enduring deficiency and indicative of a failure of settler-colonial government. Kooris endured racialised projects that sought to shape, normalise, and instrumentalise their conduct, thoughts, decisions, aspirations, oppressing kinship, language, culture, and cultural identity.

The late 1940s marked the end of protectionism and the beginning of an era of assimilation. Like protectionism, assimilationism was a product of settlercolonialism's twin logics of progress and elimination (Wolfe 1999). With Indigenous interests and autonomy erased, assimilation was to progress the socially and economically deficient Indigenous individual toward the norms of white settler-colonial society. With both protectionism and assimilationism, authoritarian measures that limited the liberty of First Nations peoples aimed to cultivate the civilised habits and pre-requisite liberal techniques of government within a market economy. The white civilising lens through which life is viewed was a paternalistic lens of white western modernity. The objective was to assimilate the individual Indigenous subject into the mainstream economy and Australian way of life, a political rationality that still creeps into the twin logics of neoliberal poverty governance as it is applied to First Nations peoples.

\section{Renewing Indigenous life projects: the failure of post-World War II Indigenous relocation programs}

The 1950s to 1970s was a significant period of Indigenous relocation to cities across Australia too. George Morgan observes, 'Aboriginal communities were established in places like Fitzroy and Footscray in Melbourne, Fortitude Valley in Brisbane, Adelaide's West End and in Allawah Grove and to the east of Perth. ... Aboriginal people were relocating to the older inner Sydney suburbs of Redfern, Waterloo, Surry Hills, Erskineville and Newtown' (Morgan 2006, 47).

Relocation to cities was the effect of earlier acts of dispossession and policies of relocation. Interviews, oral histories, and historical documents indicate that the slow relaxing of Aboriginal protection laws in New South Wales in the 1950s initially led to greater mobility and relocation to cities. While the details of each story may vary, the reasons that Kooris relocated from the rural and regional parts of the Australian state of New South Wales to cities like Sydney, Newcastle, and Wollongong are similar. Inability to access employment, housing, adequate education, and the apartheid system in rural and regional localities are the primary reasons that Kooris gave for relocating to cities. Cities offered a means of escaping the assimilative oppression of government control and surveillance on reserves and missions, the poverty in the camps on rivers on the edge of townships, and the apartheid in rural and regional townships of northern and western New South Wales. Morgan expands on this in the context of First Nations peoples who relocated to the inner western Sydney suburb of Redfern, noting that cities were places where Kooris 'were not watched so intensively by police and welfare authorities' (Morgan 2006, 46). Kooris who came to cities were escaping the institutionalised 
system of racialised segregation and discrimination that meant that they had no choice but to live in poverty with very little chance of social mobility.

The city of Newcastle, like the cities of Auckland, Chicago, New York, Sydney, Toronto, and Vancouver, became a place where First Nations peoples with varying life stories migrated and engaged in the renewal of Indigenous life projects and new visions of the world (Blaser 2004). Over the last seven decades, First Nations peoples relocating to Newcastle include direct descendants of the Awabakal traditional owners, who were displaced and dispossessed by historical laws, policies, and practices. A young Awabakal woman grew up in Australia's most north-eastern coastal city of Cairns but decided to relocate nearly $3,000 \mathrm{~km}$ south to the north-eastern coastal city of Newcastle. Awabakal nation is where her great-grandfather, in her own words, 'had been one of the last Awabakal descendants who lived unrestricted on country' (transcript 51). As she says: 'Yeah, things happened back in the days where all of my family had been born and raised in Far North Queensland ... that's the life we know up there' (transcript 51). As this young Awabakal woman declared, when she came to Newcastle an opportunity opened up for her as a language researcher at a community-based and controlled First Nations organisation engaged in language resurgence. She relocated her life project to Awabakal nation, engaging in the resurgence of her identity and connection with country. She now speaks her great-grandfather's language and officiates with her grandmother, an Awabakal Elder, at many local events giving the 'Welcome to Country', which is a ceremony at the beginning of an event where a traditional Indigenous custodian or Elder welcomes people to their nation.

In December 2013, the young Awabakal woman and her grandmother opened the Special Olympics Asia Pacific Games in Newcastle with a Welcome to Country in Awabakal language. Reclaiming her great-grandfather's language is significant. This, and working for a highly successful, internationally recognised First Nations organisation that facilitates Awabakal and other First Nations language resurgence, makes her proud. In moving to the city of Newcastle, her life project diverged from the universalist visions imposed on her by the state (Blaser 2004, 27). She was not looking for the opportunity to get a 'real job' (former Prime Minister Abbott 2015). She was already training for a qualified trade and had a job. In making the journey back to the matrilineal nation of her direct descendants, she has had the opportunity to heal her family and to reclaim her Awabakal culture, identity, and language - something that was stolen from her family in previous generations. She is engaged in the revival of Awabakal language and is a language research officer. This young Awabakal woman's story about relocation is a localised, deontological process of cultural strengthening that operates along familial and kinship lines (Bargh 2007, 17). It is a story of a distinctive agent in a progressive history (Blaser 2004, 27).

Relocating to Awabakal nation from other parts of the Australian state of New South Wales, Kooris relocated their life projects to this city. Returning to her homeland is part of the life journey of Aunty Sandra Griffin, who was born in Taree in 1946. Aunty Sandra has always identified as a descendent of the Pambalong clan of 
the Awabakal people through her great-great grandmother, who was born in Newcastle (Gregory 2018, 1). Aunty Sandra has played a significant role in First Nations resurgence and recovery in Newcastle. She was the first Elder in residence at the University of Newcastle's Wollotuka Institute and has been involved in many community organisations, including the Awabakal Cooperative, at the Elders service, and the Awabakal Medical Centre (Gregory 2018, 1). As Gregory notes, Aunty Sandra has also 'worked at Warlga Ngurra Women and Children's Refuge, as a cleaner and cook at Durungaling and occasionally at Kirinari' (Gregory 2018, 1).

\section{Koori relocation from the rural areas to cities}

The pressure on Aboriginal people to leave their country and community became acute during the 1950 s and $1960 \mathrm{~s} . .$. The need for jobs was an important pressure on rural Aboriginal people as it was for white workers. . . Aboriginal frustration with the suffocating racism of country towns. . . [T] $]$ here were fewer and fewer jobs ... in rural areas, but there were increasing opportunities in factories in the industrial cities on the coast. . . [T] he white working class abandoned rural areas far more quickly than did Aboriginal workers, and for a while this eased the job situation. ... [T] he pressure of economic need began to draw Aboriginal workers and their families too.

(Goodall 2008, 345-384)

Post-World War II cities like Sydney, Newcastle, and Wollongong were industrial areas of importance. The industrial post-World War II city offered new economic, political, and social opportunities. Industries provided dependable, long-term employment. Labour shortages in industrial cities meant First Nations peoples could secure employment in the burgeoning industries, such as the Eveleigh Railway Yards in Sydney or the BHP Steelworks in Newcastle.

Newcastle was a thriving port and industrial city (Brayshaw 1986). Newcastle's economic growth was stimulated during World War II, making it a key industrial area of importance and an essential Australian post-war city whose economy had been strengthened and diversified as a result of World War II (Suters Architects 1997). One of Newcastle's economic strengths was that it was a major port city. It was formed on the backbone of coal and copper mines and steel and soap industries in the second half of the 20th century. Coal, copper, steel, and soap were its major industries. BHP had made Newcastle the centre of industry and the largest employer ahead of the State Dockyards. The city also had other smaller manufacturing sectors, including the William Arnott's Biscuit Factory and Eastern Nitrogen. Employment was a big drawcard.

The draw card was employment and I think this is a big centre, like Redfern was, as a draw card to people coming from other places here. Now with that, there - you got people that are coming here primarily, they're looking for work. 
I think we've been luckier here in Newcastle. There's been employment going back - we've had BHP here for what? Two generations, could be even longer. So - and for Aboriginal families, I think - and not just from the Newcastle area, but a lot of people came from out of the region as well, and were able to get employment there. ... I think we have opportunities for want of anything else. We've had employment. We've had tube makers; we've had the wharfs here. So, I think when you don't have the struggle, as some other Aboriginal communities have had - there's just that constant daily struggle of putting food on the table. When that's not such a huge stress - and I know it's still stressful, and it hasn't been easy for all families. But when that's not such a huge stress in your life, there are other things that you can manage to get done.

(transcript 4)

The Newcastle BHP Steelworks was a major employer of Kooris up until the end of the 20th century. As one prominent Koori noted, 'BHP was a spring of life.... It was not racist or biased. There were no barriers, BHP did that' (Bill Smith, cited in Maynard 2001, 264).

In 1943, certificates of exemption were created in the Australian state of New South Wales by the 'Aboriginal Welfare Board' under the NSW Aborigines Protection (Amendment) Act 1943. Those Kooris who relocated to cities from reserves received from the government a certificate of exemption that Aboriginal people called 'dog tags'. This certificate of exemption gave Kooris citizenship rights and exempted them from the restrictions of state protection laws. They had to agree to adopt a 'white' lifestyle and values, to not associate with those on the reserve except their immediate family, and to give up their culture. Kooris had to carry their exemption certificate with them all the time. It could be revoked at any time. The certificates were no longer needed in 1967 and were abolished in 1969 under the NSW Aborigines Act 1969.

Those who relocated to Newcastle did not merely become 'urban workers' to improve their economic circumstances. They migrated their life projects to urban contexts (Blaser 2004; Barras 2004). Similar to other urban localities, Kooris who migrated to Newcastle came to pursue interests, aspirations, needs, goals, and objectives offered within the urban landscape, resulting in strong and diverse First Nations identities existing in Newcastle (Newhouse \& Peters 2003, 10). Relocation entailed resilience from the historical injustices of dispossession, removal, oppression, and racism and cultural, social, political, and economic resurgence. Resurgence from historical injustices involves the resurgence of cultural, political, and social agency.

Reserve life, and transience, then later a new life in the city did not equate to a loss of culture. Kooris who relocated to Newcastle maintained strong connections with kin and country in rural localities predominately in the west and north-west of New South Wales - areas with high levels of racism and high unemployment rates. As local Elders explain in later quotes, Kooris who relocated to Newcastle 
continued to engage in cultural practices. They were raised in culture and continued to return to country to maintain connections with matrilineal and patrilineal kin and nations.

Koori Elder narratives about living in a dispossessed state during the protection era in New South Wales and shortly after represent the experience of loss associated with a cumulative series of events and policies (Turner et al. 2008). ${ }^{1}$ These Elders also describe efforts to survive - revealing a theme of cultural resilience and later recovery. Within the narratives is a sustained and fluid sense of cultural identity. Resilience is not expressed as an individual trait, as a predisposition to succeed despite adversity, but instead it is voiced as the persistence of cultures and collectivities (Thomas, Mitchell, \& Arseneau 2016, 116). It is sociological in character and associated with cultural identity. Koori narratives echo First Nations peoples narratives in Canadian contexts concerning loss in which culture and language are articulated as essential resources of resilience for individuals and communities (Thomas, Mitchell, \& Arseneau 2016, 3).

What follows, then, identifies that Indigenous loss and struggle are central to Koori Elder relocation narratives, as too is the resilience of culture and identity. Loss, cultural resilience, and recovery relate to the social practices of retaining and maintaining culture and identity in the face of adversity. What the narratives express is how the resurgence of cultural identity is critical to individual Koori Elders. Indigenous resilience and cultural resurgence later shape community building and development. A community movement for Indigenous resurgence emerges out of relocation, a community movement grounded in Indigenous knowledge (Simpson 2011).

Here are the brief life histories of five Kooris Elders who relocated to Newcastle and who later went on to contribute in their own ways to Indigenous community building and development in this city, becoming prominent Elders in the Newcastle community.

\section{The Smith brothers: Uncle Bob and Uncle Bill's story}

The Smith Brothers, Robert and William, came to the Newcastle region from Uralla to take up opportunities for work 'on the badly damaged rail lines after the 1955 Maitland flood' (Maynard cited in Lake Macquarie history 2017). The brothers were born in Tamworth in the early 1930s, and their family had lived at the small village of Woolbrook in the New England area before they moved to Uralla at an early age as their father secured employment on the local railway gang (Maynard 2001, 259).

The Smith brothers won a big contract with BHP in 1969 and started Smiths General Contracting Pty. Ltd. From the 1950s to 1980s, the Smith brothers brought Koori men and women from all over New South Wales to Newcastle. They provided them with regular employment and opportunities to acquire specialised job skills in railway engineering and large industry, especially with BHP. During its 
heyday, the company Smith General Contracting employed over 130 men: 70 per cent were Koori men (Maynard cited in Lake Macquarie history 2017). The Smith brothers were also Indigenous activists and community entrepreneurs, setting up a funeral fund and credit funds - 'the company was ahead of its time' (Interview with Ray Kelly Senior in Maynard 1999). The company sponsored Koori workers through technical college and university. The Smith brothers become the largest private employer of Indigenous labour in Australia. As Dhungutti man Ray Kelly Senior notes of his own interactions with the Smith brothers - 'these men were great role models - inspirational experience' (Interview with Ray Kelly Senior in Maynard 1999).

\section{Uncle Gerry Edwards' story}

Uncle Gerry Edwards is a Bunjalung man (Edwards, cited in Koori Elders 2013). He was born in the regional town of Grafton in NSW (Edwards, cited in Koori Elders 2013). His father is a Kamilaroi man from Caroona Mission near Tamworth, and his mother comes from Armidale (Edwards, cited in Koori Elders 2013). Uncle Gerry's mother and grandmother were born in Cherbourg (Edwards, cited in Koori Elders 2013), which was one of the largest Aboriginal missions in the Australian state of Queensland, with one of the most fraught histories of Australian missions. It has been called a 'Dumping Ground' (Blake 2001). Its occupants were segregated into dormitories, which included a separate dormitory for children (Blake 2001). They were also hired out for casual labour. At one stage, it is believed there were 28 First Nations groups from Queensland and NSW in Cherbourg Mission (Blake 2001). As Blake writes, 'Cherbourg was a social experiment in institutional control that was to impact on the lives of thousands of Aboriginal families'. And, as Blake goes on to note, 'in attempting to destroy cultural forms, the reserve system instead prompted greater cultural resilience. ... [T] he place that was a dumping ground . . . also became a place of resistance and survival' (Blake 2001, 245). Today, Cherborg is an Aboriginal community town. Uncle Gerry Edwards tells his story as follows:

We used to eat wild food. The little berries along the creeks. Lilly pillie and wattle gum. Then we used to eat what we call witchetty grubs. We call them Jubal in Bunjalung language. Parrots. . . . We ended up going to Tabulam Aboriginal Reserve. There was no electricity on that mission either. They used to have to get rations. A lot of them used to come home with Kangaroos and clean Kangaroos. ... Turtle divers came home with fresh water turtles. From there I went to a little place called Tingha. You could get around in those days and find a bit of tin and saphires ... and sell them for money. My brother ended up going to Tenterfield and he got a job at the meatworks. My mum ended up following him there. We all ended up in Tenterfield. That was my first job. I ended up working in Andersons Meat Works in Wallengarah. Then I got a car. I ended up at 20 at a place called Ashford and I got married 
and I had a few kids. I ended up coming to Newcastle in 1971. I got a job at Eastern Nitrogen [producers of fertilisers] at Kooragan Island. (Interview with Uncle Gerry Edwards, Koori Elders 2013)

Uncle Gerry's account of relocation explains how First Nations peoples not only came to Newcastle for employment, but they were trying to escape chronic poverty, transience, and apartheid experienced in rural New South Wales. What is embedded in this brief extract from Uncle Gerry's life story is his matter-of-fact reference to his engagement in cultural practices as a child, particularly the eating of bush foods to supplement rations. Uncle Gerry was NAIDOC week Elder of the Year in 2015. He sadly passed in 2016.

\section{Uncle Jimmy's story}

Uncle Jimmy was born in a segregated section of Taree hospital (Elsworthy 2014, 1). While he grew up on nation, his family lived in the mission of Purfleet, which was one of the Aboriginal reserves in the state. Uncle Jimmy's family experienced extreme poverty. He received a very poor level of education provided at the Aboriginal School at Purfleet (on the Purfleet Aboriginal reserve, which was located on the edge of the Australian coastal town of Taree in the state of New South Wales) and later the mainstream education system. His father experienced difficulties getting regular work. These are the reasons he gives for his family relocating to Newcastle in the 1950s.

I was born in the Australian regional town of Taree back in 1942 and lived my younger life at Purfleet [Aboriginal mission]. Growing up at Purfleet was different. We lived on a lot of bush tucker to supplement our rations that would come around every fortnight with the flour, tea, sugar, bread, meat. We did a lot of fishing. Our Elders used to take us around the creeks getting Cobra, which is long white bora grub that lived in the salt water log. They were quite a delicacy. We went to a mission school to start with in Taree and the teacher there was the bloke who runs the show's wife. She was about as educated as we were. Then we went to Taree Public School. We never learnt much there. They stuck us in a corner. They didn't have to teach us. We more or less taught ourselves to read and write. Dad came down to Newcastle because he was a bit fed up with the apartheid system where you couldn't go to a pub, you couldn't do this, you couldn't do that. ...

(Interview with Clifford James Ridgeway, Uncle "Jimmy" Ridgeway, Koori Elders 2013)

In relocating to Newcastle, Uncle Jimmy's family did not isolate themselves from nation or kin. Uncle Jimmy's mother was born in Karuah, which is Worimi country, on the edge of Awabakal nation to the north-west of Newcastle, and his father was born in Foster and lived most of life in Taree. Jimmy identified "with the 
Biripi mob more so than the Worimi mob but by Aboriginal lore I should take my mother's side, but I do in one way but my father's side is stronger because I lived in his country - that's where I grew up' (Interview with Clifford James Ridgeway, Uncle Jimmy, Koori Elders 2013).

Uncle Jimmy comments that on coming to Newcastle he saw no in-your-face racism like you saw in the regional town of Taree; he could go to the movies or get on a bus and sit anywhere. While he did not encounter the racism that he had encountered in the town of Taree, Uncle Jimmy explains that life was not that great in Newcastle. His family lived in Platt's Estate - a shantytown in the heart of Newcastle. Uncle Jimmy explains that a better life was not in the middle-class suburbs of cities. The capacity to secure housing or accommodation was a major issue because of the racism and prejudice (Guth \& Vallance 1972, 46-48). That is, racism still existed in the cities, and access to housing was where it became most obvious. Racism and segregation had made it difficult to find housing in cities. First Nations peoples either lived in the 'notorious slums areas' (Morgan 2006, 48) or in the shanty towns of cities. In the inner Sydney suburbs, they lived in the 'much decaying nineteenth-century housing, large terraces which had been neglected by their slum landlords' (Morgan 2006, 47). In Newcastle, the shantytown of Platt's Estate in the Newcastle suburb of Waratah or the shantytown of Texas in the Newcastle suburb of Carrington were two inner-city localities where First Nations peoples ended up living when they relocated to Newcastle from the 1940s to 1970s. What happened in many cases, though, was that those who took up residence in the "notorious slum areas ... were doubly marginalised ... both on their basis of race and because they were associated with the "undeserving poor" who inhabited these regions' (Morgan 2006, 48). First Nations peoples living in Sydney suburbs were identified as a distinctive, pathologised sub-culture who were 'represented in the popular press (and in some academic accounts) as a deviant and potentially subversive presence' (Morgan 2006, 48) and later heavily policed.

Relocation to the city led Uncle Jimmy on a continuous search for something better and a personal journey of engagement in resurgence practices through music and re-learning his patrilineal First Nations language. While he grew up on country, he lived on a reserve and his life was managed for him. Jimmy's family left his patrilineal nation, moving closer to his matrilineal nation, because of the racism in Taree and the way that his family was treated in Taree and on the Purfleet reserve. Uncle Jimmy's Elders taught him about his culture, and he continued to carry their stories and cultural practices with him. Uncle Jimmy's childhood narrative and his narrative about his early movement from one job to another reflect a theme of alienation from his first job in the circus. Uncle Jimmy later became an Aboriginal relocation officer on the NSW Aboriginal Family Relocation program in Albury. He was proud to be the first Koori 'to be employed as a prison guard in NSW, but he left the position because he was saddened by the number of Indigenous inmates' (Elsworthy 2014, 1). After meeting his wife, he resettled in Newcastle, pursuing a career in music and then 
becoming a successful local artist. Uncle Jimmy re-connected with his patrilineal First Nation language. He went on to become a respected Koori Elder in the greater Newcastle region, performing Acknowledgements of Country in his own language.

\section{Aunty Zelma Moran's story}

Aunty Zelma Moran is (still alive) a descendent of Aniawan clan from the New England area and 'both parents were Aboriginal and working class people and they reared us to be workers to get educated and to respect other people' (interview with Aunty Zelma Moran, Koori Elders 2013). She grew up on pastoral land in Nowendoc, outside of Tamworth in NSW. They lived off the land. Her father was a drover, and her mother did housework for other families in the area. When her brothers grew up and had to get jobs, they moved to Aberdeen. Her mother worked in the hotel as a cleaner. In 1957, Aunty Zelma, who worked in a Greek Café in Scone, went on to get a job as 'a waitress on the Armidale Express, the Grafton Express, the Albury Express and was trained on the old Newcastle flyer' (Interview with Aunty Zelma Moran, Koori Elders 2013). In 1972, 'we moved to Newcastle and I got a job at the Awabakal Co-op. I was employed as a field officer' (Interview with Aunty Zelma Moran, Koori Elders 2013). 'Then I got a job in 1978 in the Health Commission NSW. I worked for 20 years in my job in the Health Department. I retired when I turned 60. Toronto [on the western side of Lake Macquarie] has since become my home' (Interview with Aunty Zelma Moran, Koori Elders 2013).

Like many others, Aunty Zelma did not disclose that she was a First Nations woman of Anaiwan descent when she applied to work for the railway. If she had, she believed she would not have gotten the job (Interview with Aunty Zelma Moran, Koori Elders 2013). As Worimi historian Professor John Maynard comments in relation to Kooris who hid their identity or attempted to adopt another identity passing themselves off as Indian, Maori, Jewish, Islander, or European to escape the enforced stigma and limited ability to provide for their families caused by being seen or perceived to be Aboriginal, 'the levels of this identity persecution and character assassination to which Aboriginal Australians were subjected is today little understood or recognised' (Maynard 2001, 249). Author and Birpai man, John Heath also comments on the fact that, while such events were at odds with legal restrictions, they were also 'an illustration of the benevolence of some or perhaps the willingness to "turn a blind eye" if the situation was of benefit to the [non-Indigenous] community' (Heath 1998, 60).

Aunty Zelma went on to become an important figurehead locally. She was one of the first Kooris to be employed at the first local community-based First Nations organisation to be established in Newcastle. She has since been active locally in the greater Newcastle community and is an Elder in the community. 


\section{The Indigenous family resettlement program}

There was a shift in state policy toward urban integration in the 1960s (Morgan 2008 , 1). For example, 'initially, in response to Indigenous population pressures in rural areas, the Aboriginal Welfare Board sought to relocate "worthy" Aboriginal families to suburban homes, some in country towns but many in Sydney' (Morgan 2008, 1). The city of Newcastle was a site of a government relocation program and social experiment designed in collaboration between government departments and researchers at the University of New England to 'rehabilitate' Aboriginal people (Guth 1971). In 1971, the Federal Office of Indigenous Affairs embarked on the pilot voluntary-assisted Aboriginal resettlement program from disadvantaged rural areas of New South Wales to the non-metropolitan cities (Gorring 1991); this program was known as the Indigenous Family Resettlement Scheme. It relocated 28 Koori families from rural NSW to the then non-metropolitan city of Newcastle, including 17 families from Bourke (five of which returned to Bourke) and two families from Wilcannia. The program was based on an experimental design aimed at 'rehabilitation with sufficient funding to ensure individual success [that] appears to offer long-term financial, social and moral appeal' (Mitchell 1978, x). That is, 'Aborigin[al people] in unviable country areas might be induced to come to an urban area where their life chances could be considerably enhanced' (Mitchell 1978, x). It was designed and overseen by a researcher from New England University who documented the intent of the project, the process of choosing Kooris families and individuals, and the relocation of the Koori families and individuals to Newcastle (Mitchell 1978, x). While urban areas offered greater opportunities, Mitchell also recognised that urban areas could potentially create adversity and trauma and replicate the difficulties experienced by Kooris in rural areas (Mitchell 1978). The idea of the project was to assist with successful transition (Mitchell 1978; Gorring 1991). The Interim Report: Newcastle Research Project indicates that the project chose Kooris who would be 'prepared to function in middle-class Australia', as the project objective was to assimilate young Kooris and their families into middle-class Australia of which 'Newcastle offered many of the pleasant things that are part of middle-class Australia' and apparently had 'no slums' (Guth 1971, 2).

Kooris who participated in the resettlement program were motivated by apartheid, chronic poverty, white apathy, intermittent employment, and the lack of opportunities for children in the rural areas of the Australian state of New South Wales. This is represented in the following quotes from those who participated in the program.

Things weren't real good for Aboriginal kids because they were discriminated against all the time. Nobody really cared about how we (were) going or even if we stayed. 
There was no work and I had the kids to look after as well. They needed a future you know, rather than being stuck in a place like Bourke. . . . [T] he kids are the main reason for coming because they had no opportunities otherwise.

(Respondent 8 in Gorring 1991, 88)

There was a real feeling of apartheid. A lot of people don't realise that you know. What was going on in this country in those days made it very difficult to get a schooling of any sort under conditions based on colour. . . . When you turned eighteen back home, you were picked up by the police because they had records on us. That was your introduction to jail mate. See, because the registry books of births and deaths was always kept at the police station. What they would do was go through and see who was turning eighteen. They knew who you were. They would come along and pick you up and help you 'celebrate'. Good life eh?

(Respondent 7 in Gorring 1991, 83-85)

Relocation to the city came from a history of dispossession and relocation. Some Kooris were living on their homelands on reserves, but they were still dispossessed from them. They were escaping the apartheid that now existed in rural and regional areas in New South Wales.

In the 1950s, 1960s, and 1970s, Newcastle was a thriving port and industrial city (Brayshaw 1986). Relocation offered a means of escaping the poverty on missions, reserves or camps on the edge of townships. Aboriginal people who came to the industrial city of Newcastle worked in its burgeoning industries. BHP Steelworks in Newcastle became one of the biggest employers of First Nations peoples. It was also the first to pay equal wages to First Nations peoples.

It was not easy adjusting to life in the city. This better life was not in the middleclass suburbs of cities. Many also experienced social isolation in this city.

By 1974, about 1,000 Kooris 'had come to Newcastle to escape the appalling conditions on reserves' (Jonas 1991, 52). This is a pivotal moment in terms of not only Koori connection to the railway in the Australian state of New South Wales, but also Indigenous resurgence and community development in the Australian city of Newcastle and its surrounding areas from Toronto, on the western side of Lake Macquarie, to Karuah, north of Maitland, and the south on the Central Coast.

\section{Notes}

1 The context in which they are discussing Indigenous loss differs, but the basic premise that they put forward holds constant. They call for invisible loss to be made transparent and then identify eight forms of invisible loss. The eight forms include cultural and lifestyle losses, loss of identity, health losses, loss of self-determination and influence, emotional and psychological loss, loss of order in the world, knowledge losses, indirect 
economic loss, and lost opportunities. The eight forms of invisible loss have historical and contemporary dimensions. Furthermore, Turner et al. illustrate how the eight themes overlap, explaining how 'most are exacerbated by the compounding of two or more effects in a turmoil of interlinked causes and effects that are exceedingly difficult to distinguish' (Turner et al. 2008).

\section{References}

Abbott, T (2015). 'Transcript of Joint Doorstop Interview: Kununurra, WA: 23 August 2015: Development of Northern Australia; Ord Stage 3; Prime Minister's Visit to the Torres Strait; Cashless Welfare card; Daesh Death Cult; Syria', http://parlinfo.aph.gov.au/parlInfo/ search/display/display.w3p;query=Id\%3A\%22media $\%$ 2Fpressrel $\% 2 \mathrm{~F} 4032659 \% 22$, accessed 3 December 2015.

Agamben, G (2005). 'State of exception', Nova srpska politička misao, Vol. 12, No. 4, pp.135-145.

Banivanua Mar, T \& Edwards, P (2010). Making Settler Colonial Space: Perspectives on Race, Place and Identity. New York: Palgrave Macmillan.

Barcham, M (2004). 'The Politics of Maori Mobility', Population Mobility and Indigenous Peoples in Australasia and North America, pp. 163-183.

Bargh, M (2007). Resistance: An Indigenous Response to Neoliberalism. Wellington: Huia Publishers.

Barras, B (2004). 'Life Projects: Development Our Way', in In the Way of Development: First Nations Peoples, Life Projects and Globalization. London: ZED Books, pp. 47-51.

Blake, T (2001). A Dumping Ground: A History of the Cherbourg Settlement. Brisbane: University of Queensland Press.

Blaser, M (2004). 'Life Projects: First Nations Peoples' Agency and Development', in Blaser, M, Feit, H \& McRae, G (eds.), In the Way of Development: First Nations Peoples, Life Projects and Globalization. London: ZED Books, pp. 23-43.

Blyton, G (1995). 'First Contact', in Turner, J \& Blyton, G (eds.), The Aboriginal of Lake Macquarie: A Brief History. Lake Macquarie, NSW: Lake Macquarie City Council.

Brayshaw, H (1986). Aborigines of the Hunter Valley: A Study of Colonial Records. Scone, NSW: Scone \& Upper Hunter Historical Society.

Carey, H M (2010). 'Lancelot Threlkeld, Biraban, and the Colonial Bible in Australia', Comparative Studies in Society and History, Vol. 52, No. 2, pp. 447-478.

Chudacoff, H, Smith, J \& Baldwin, P (2016). The Evolution of American Urban History, 8th Edition. New York: Routledge.

Cornell, S (2000a). 'Discovered Identities and American Indian Supratribalism', in Spickard, P \& Jeffrey Burroughs, W (eds.), We Are a People: Narrative and Multiplicity in Constructing Ethnic Identity. Philadelphia: Temple University Press, pp. 98-123.

Cornell, S (2000b). 'That's the Story of Our Life', in Spickard, P \& Jeffrey Burroughs, W (eds.), We Are a People: Narrative and Multiplicity in Constructing Ethnic Identity. Philadelphia: Temple University Press, pp. 41-53.

Elsworthy, E (2014). 'Obituary: Clifford James “Jimmy” Ridgeway', The Newcastle Herald, 11 May.

Fixico, D (1990). Termination and Relocation: Federal Indian Policy, 1945-1960. Albuquerque, NM: University of New Mexico Press. 
Furlan, L M (2017). Indigenous Cities: Urban Indian Fiction and the Histories of Relocation. Lincoln and London: University of Nebraska Press.

Goodall, H (2008). Invasion to Embassy: Land in Aboriginal Politics in New South Wales, 1770-1972. Sydney: Sydney University Press.

Gorring, B T (1991). Sponsored Aboriginal Resettlement to Newcastle and Albury. PhD Thesis, University of Newcastle, Newcastle.

Gregory, H (2018). 'Because of Her, We Can: Celebrating the Hunter's Aboriginal Women of Influence', The Newcastle Herald, 8 July 2018, www.newcastleherald.com.au/ story/5509019/because-of-her-we-can-celebrating-the-hunters-aboriginal-women-ofinfluence/.

Grieves, V (2002). 'Margaret of the Awabakal (c.1829-1894)', in Roberts, D A, Carey, H M \& Grieves, V (eds.), Awaba: A Database of Historical Materials Relating to the Aborigines of the Newcastle-Lake Macquarie Region. University of Newcastle, www. newcastle.edu.au/group/amrhd/awaba/.

Guth, S O (1971). Interim Report: Newcastle Aborigine Research Project. Armidale: The University of New England.

Guth, S O \& Vallance, G A (1972). Aboriginal Rural-Urban Migration: The Newcastle Project. Armidale: University of New England.

Heath, J (1998). 'Muloobinbah: The Contributions of Aboriginal People to the Resources of the Hunter Region', in Hunter, C (ed.), Riverchange. Newcastle: Newcastle Region Public Library.

Hill, G \& Cooke, M (2014). 'How Do You Build a Community? Developing Community Capacity and Social Capital in an Urban Aboriginal Setting', Pimatisiwin, Vol. 11, No. 3, pp. 421-432.

Hugill, D (2017). 'Colonial and Postcolonial Cities', in Turner, B S (ed.), The WileyBlackwell Encyclopedia of Social Theory. London: Wiley-Blackwell.

Johnston, A (2012). 'Religion and Law in Colonial New South Wales: Lancelot Threlkeld and Settler-Colonial Humanitarian Debates', in Kirby, D (ed.), Past Law, Present Histories. Canberra: ANU Press, pp. 23-38.

Jonas, W (1991). Awabakal, Bahtabah, Biripi, Worimi: Four Successful Aboriginal Organisations. Newcastle: University of Newcastle.

Keary, A (2009). 'Christianity, Colonialism, and Cross-Cultural Translation: Lancelot Threlkeld, Biraban, and the Awabakal', Aboriginal History, pp. 117-155.

Keating, A D (2012). Rising Up from Indian Country: The Battle of Fort Dearborn and the Birth of Chicago. Chicago: University of Chicago Press.

Keenan, S (2014). 'Moments of Decolonization: Indigenous Australia in the Here and Now', Canadian Journal of Law and Society, Vol. 29, No. 2, pp. 163-180.

Koori Elders (2013). Stories from Past to Present (Videorecording). Aboriginal Affairs, Office of Communities, NSW Government, Sydney.

Lobo, S (2002). Urban Voices: The Bay Area American Indian Community. Arizona: University of Arizona Press.

Maynard, J (2001). 'Muloobinbah (Newcastle) an Aboriginal Industrial Presence: Past and Present', Journal of Royal Australian Historical Society, Vol. 87, No. 2, pp. 248-266.

McMullen, S (1997). Disunity and Dispossession: Nawash Ojibwa and Potawatomi in the Saugeen Territory, 1836-1865. Calgary: University of Calgary.

Mitchell, I S (1978). Aborigines on the Move: Personal Adjustment in the Resettlement of Aboriginal Families: A Psychosocial Study. Sydney: University of New South Wales. 
Mixed Mobs Exhibition (2001). 'Aboriginal Dreamtime of the Hunter Region Mixed Mobs Exhibition', Aboriginal collections held by the University of Newcastle.

Morgan, G (2006). Unsettled Places: Aboriginal People and Urbanisation in New South Wales. Adelaide: Wakefield Press.

Morgan, G (2008). 'Aboriginal Migration to Sydney Since World War II', Dictionary of Sydney, http://dictionaryofsydney.org/entry/aboriginal_migration_to_sydney_ since_world_war_ii.

Morgensen, S L (2011). 'The Biopolitics of Settler Colonialism: Right Here, Right Now', Settler Colonial Studies, Vol. 4, p. 54.

Newhouse, D R \& Peters, E (2003). Not Strangers in These Parts: Urban Aboriginal Peoples. Ottawa: Policy Research Initiative.

Newhouse, D \& Fitzmaurice, K (2012). 'Introduction: Aboriginal People in the City: From the Study of Problems to Community Engagement and the Fostering of MinoBiimaadiziwin', Well-Being in the Urban Aboriginal Community: Fostering Biimaadiziwin, a National Research Conference on Urban Aboriginal Peoples, Toronto, Canada.

Nikora, L et al. (2004). 'Indigenous Psychologies Globally - A Perspective from Aotearoa/ New Zealand', www.researchgate.net/publication/33051133_Indigenous_psychologies_ globally_a_perspective_from_AotearoaNew_Zealand.

Norris, M J, Clatworthy, S \& Peters, E (2013). 'The Urbanization of Aboriginal Populations in Canada: A Half Century in Review', in Peters, E \& Andersen, C (eds.), Indigenous in the City: Contemporary Identities and Cultural Innovation. Vancouver: UBC Press, pp. 29-45.

Peters, E J (2002). 'Our city Indians: Negotiating the Meaning of First Nations Urbanization in Canada, 1945-1975', Historical Geography, Vol. 30, pp. 75-92.

Peters, E \& Andersen, C (2013). Indigenous in the City: Contemporary Identities and Cultural Innovation. Vancouver: UBC Press.

Pollak, M (2016). 'Reflection on Urban Migration', American Indian Culture and Research Journal, Vol. 40, No. 3, pp. 85-102.

Rifkin, M (2009). 'Indigenizing Agamben: Rethinking Sovereignty in Light of the "Peculiar" Status of Native Peoples', Cultural Critique, Vol. 73, Fall, pp. 88-124.

Roberts, D A (2008). “ "Language to Save the Innocent”: Reverend L. Threlkeld's Linguistic Mission', Journal of the Royal Australian Historical Society, Vol. 94, No. 2, p. 107.

Rosenblatt, D (2002). 'Titirangi Is the Mountain: Representing Maori Community in Auckland', Pacific Studies, Vol. 25, No. 1, pp. 117-140.

Rosenthal, N G (2012). Reimagining Indian Country: Native American Migration and Identity in Twentieth-Century Los Angeles. Chapel Hill: University of North Carolina Press.

Russell, P (2005). Recognising Indigenous Title: The Mabo Case and Indigenous Resistance to English-Settler Colonialism. Toronto: University of Toronto Press.

Ryks, J, Howden-Chapman, P, Robson, B, Stuart, K \& Waa, A (2014). 'Maori Participation in Urban Development: Challenges and Opportunities for Indigenous People in Aotearoa New Zealand', Lincoln Planning Review, Vol. 6, No. 1-2, pp. 4-17.

Ryks, J, Pearson, A \& Waa, A (2016). 'Mapping Urban Māori: A Population-Based Study of Māori Heterogeneity', New Zealand Geographer, Vol. 72, No. 1, pp. 28-40.

Scott, J C (2009). The Art of Not Being Governed. New Haven: Yale University Press.

Simpson, L B (2011). Dancing on Our Turtle's Back: Stories of Nishnaabeg Re-Creation, Resurgence, and a New Emergence. Winnipeg, MB: Arbeiter Ring Publishing. 
Suters Architects (1997). 'Newcastle City Wide Heritage Study by Suters Architects', prepared on behalf of Newcastle City Council 1996/7.

Thomas, D, Mitchell, T \& Arseneau, C (2016). 'Re-Evaluating Resilience: From Individual Vulnerabilities to the Strength of Cultures and Collectivities Among Indigenous Communities', Resilience, Vol. 4, No. 2, pp. 116-129.

Tomiak, J (2013). 'Challenging the Neoliberal Settler City: The Urban Aboriginal Strategy, the Politics of Displacement, and Indigenous Resistance', paper presented at the annual conference of the Canadian Political Science Association.

Turner, N J, Gregory, R, Brooks, C, Failing, L \& Satterfield, T (2008). 'From Invisibility to Transparency: Identifying the Implications', Ecology and Society, Vol. 13, No. 2, pp. 7-21.

Weaver, H N (2012). 'Urban and Indigenous: The Challenges of Being a Native American in the City', Journal of Community Practice, Vol. 20, pp. 1-19.

Williams, M M (2015). Panguru and the City: Kãinga tahi, kāinga rua: An Urban Migration History. Wellington: Bridget Williams Books.

Wolfe, P (1999). Settler Colonialism. London: Cassell.

Wolfe, P (2006). 'Settler Colonialism and the Elimination of the Native', Journal of Genocide Research, Vol. 8, No. 4, pp. 387-409. 


\title{
Indigenous resurgence in settler-colonial cities
}

\author{
From social movements to \\ organisation building
}

[E]specially through the seventies and I think - and through the eighties and parts of the nineties - I think there was this concept of unity within the community and that we need to be united people in order to advance the cause.

(transcript 57)

Post-war relocation saw the co-location of First Nations peoples in specific localities in cities, such as Little Earth in Minneapolis, the Block in Redfern, and Uptown in Chicago. In other cases, communities of association in cities like Newcastle and Oakland were not located within a specific clustered residency or neighbourhood but somewhat widely scattered, and they came together at critical locations. These localities became small communities within themselves. They mobilised resources (people, ideas, and funds). They were part of post-war projects of Indigenous resurgence. They arose from urban relocation programs and voluntary migration in the four settler nation-states of Australia (Morgan 2006), Canada (Peters \& Andersen 2013; Norris, Clatworthy, \& Peters 2013; Hill \& Cooke 2014), Aotearoa New Zealand (Rosenblatt 2002; Ryks et al. 2014, 2016; Keenan 2014), and the United States (Fixico 1990; Rosenthal 2012; Chudacoff, Smith, \& Baldwin 2016; Pollak 2016).

Chapter 3 frames the post-war relocation period as a turning point in history - a 'period of rupture' (Furlan 2017, 10). It reflects on the critical moment in which First Nations peoples came together in cities and created community-organisations to serve precisely the purpose of rupture and resurgence. What remains hidden in plain sight is the significance of this moment of rupture in terms of the creation of inter-nation or inter-tribal tight-knit communities in cities of Australia, Canada, Aotearoa New Zealand, and the US - a moment that saw the formation of some of the first, now longstanding, First Nations organisations in cities of four settlercolonial states. First Nations peoples in cities restored their capacity to be responsible for their future (Ahmet 2001).

American, Australian, Canadian, and Aotearoan New Zealand scholarship reveals comparative features to resurgence of cultural identity crafted in cities through reconnections with homelands, language and cultural practices, protocols, 
and governance (Morgan 2006; Maddison 2013; Furlan 2017). Coming together to create First Nations organisations in cities was a social movement activated through the freedom, capacity, and power of First Nations peoples. Urban Indian Centres started in the US in the 1950s. Aboriginal Friendship Centres started in Canadian cities in the late 1950s and 1960s. Aboriginal cooperatives and foundations formed in Australian cities in the 1970s. This urban social movement arose in the wake of the political movements of the time, including the Black Power movement in the US in the 1950s and the Indigenous land rights movement in Australia in the early 1970s. It was in this moment that the Awabakal Newcastle Aboriginal Cooperative was established.

The first section broadly describes this moment of rupture. The second describes the Australian political context. The penultimate section describes the recrafting of Indigenous identity in the Australian context - that is, how First Nations peoples crafted or more aptly re-crafted the self in cities, a self originally crafted by the settler nation-state (Sissons 2005, 71, 154). It describes briefly how the suburb of Redfern in inner-western Sydney became the 'birthplace of self-determination' in Australia (Burney, quoted in Morgan 2006, 63). The last section is a detailed discussion about how Kooris came together in the Australia city of Newcastle to create the Awabakal Newcastle Aboriginal Cooperative.

\section{Relocation and the formation of Indigenous community movements in cities}

The rise of Indigenous civil society institutions in cities was not detached from the localised and national struggle for Indigenous rights, self-determination, recognition, and empowerment. It occurred at a striking period of crisis, eruption, and social change in Indigenous/settler-colonial state relations (Cornell 1984, 47). First Nations peoples across Australia, Canada, Aotearoa New Zealand, and the United States were mounting a challenge to the historical structure of Indigenous-white relations. Confrontations were becoming more assertive there was an eruption of land occupations, rapid growth in Indigenous-initiated litigation, and the emergence of a host of Indigenous political organisations (Cornell 1984, 47).

In part, the localised struggle in cities can be read in the context of Miller's notion of 'Awakening' (Miller 1985) as the formation of a 'community of resistance' (Havemann 1999) deeply entrenched in the struggle for Indigenous rights (Yashar 1999, 2005; Petray 2010, 2012; Dahl 2012). Indigenous grassroots movements in cities were on the rise. So too were Indigenous occupations, protests, marches, and commemorations in cities. The civil rights movement that had taken a collective turn in cities in the 1960s with rights protests for workers, women, lesbians, gays, bisexuals, transgenders, and minorities coming to the fore (Harvey 2008).

Civil disobedience itself was on the rise in cities. In May 1968, student occupations in Paris were followed by two months of civil society unrest and general 
worker strikes. Escobar describes the aim of the struggle of grassroots movements as 'not power per se, especially not "state power", but the establishment of conditions' (Escobar 1992). Those 'conditions usually include non-formal or non-conventional forms of power in which [people] can have greater autonomy over the decisions that affect their lives' (Escobar 1992, 421). Occupy Alcatraz occurred at the peak of this movement.

The formation of Indigenous social movements in cities was an international phenomenon in which Indigenous activists brought together culturally and politically alienated and dispossessed First Nations peoples living in settler-colonial cities. They developed progressive alternative projects of their own, generating modified forms of formal and informal Indigenous institutions, vibrant infrastructures of community, youth and cultural centres, and other self-managed projects (Marcuse, Brenner \& Mayer 2012; Mayer 2017, 171). The city of Newcastle, like the cities of Auckland, Chicago, Oakland, Phoenix, Sydney, Toronto, and Vancouver, became a site of Indigenous resurgence.

\section{Indigenous community building in settler-colonial cities}

First Nations peoples who relocated to cities established a strong community base of culturally and socially enterprising First Nations organisations in the cities of Australia, Canada, Aotearoa New Zealand, and the United States. In the late 1950s and early 1960s, Aboriginal Friendship Centres were established by First Nations peoples in Canadian cities. First Nations peoples established Indian Centres in the United States. Aboriginal cooperatives and foundations were established by First Nations peoples in Australian cities, like Sydney in the 1960s and Newcastle in the mid-1970s. Organisations formed in this period include the Intertribal Friendship Centre in San Francisco Bay, the American Indian Centre in Chicago, the Phoenix Indian Center, the Vancouver Aboriginal Friendship Centre, the Native Canadian Centre of Toronto, the Awabakal Newcastle Aboriginal Cooperative, and the Manukau Urban Maori Authority. Their function has been particularly critical for urban localities in which First Nations peoples have made that locality their home. These organisations were set up to provide 'culturally vital' Indigenous spaces in cities and to create a sense of belonging and place for First Nations peoples. They also led to the explicit development of urban Indigenous self-government, urban Indigenous social infrastructure, and control over service delivery (Fitzmaurice, McCaskill, \& Cidro 2012, 19).

It is the history of the formation of First Nations organisations that reveals much about the history of Indigenous community development in cities over this time. The struggles of these organisations are the struggles of First Nations peoples in cities.

Indigenous scholars describe urban community building practices as practices rooted in Indigenous life projects (Blaser 2004; Barras 2004). Practices aimed at 'transforming the structures of power that constrain First Nations 
peoples to act and live according to criteria of Indigenousness that have no regard for their ways of conceiving themselves and their being-in-the-world' (Blaser 2004, 53), practices aimed at 'achieving autonomy in deciding their own future' (Barras 2004). Life projects and cultural strengthening in cities had local, deontological, or familial purposes (Bargh 2007, 17). The distinctly enterprising nature of First Nations organisations was their cultural and social objectives.

Over the last 75 years, Indigenous communities of association in cities have gone on to create their own institutions, social infrastructure, and social economies. The building of Indigenous social infrastructure in the form of community facilities, community services, and supporting physical infrastructure in cities channelled much of the earlier activism of urban Indigenous movements. The organisations First Nations peoples established became important expressions of Indigenous agency, empowerment, autonomy, and self-determination. First Nations peoples who came together in cities like Chicago, Oakland, Newcastle, Phoenix, Sydney, Toronto, and Vancouver created their own Indigenous space that allowed for the participation of First Nations peoples in society on more equal terms. They proved a critical democratic apparatus for social change.

Urban Indigenous self-determination in cities was achieved via the formation of organisations that involved 'the development of voice through which all of these things can be done' (Beck 2002, 118). Self-governing institutions became the standard model of Indigenous self-determination in cities (Walker 2006). Indigenous communities of interest (associational communities) created systems of self-governing institutions to take care of the 'housing, health, educational, spiritual and economic needs of First Nations peoples in urban areas, without regard to tribal origin' (Walker 2006, 2348). They became a means through which urban 'communities of interest or association' (Walker 2005) could be formed and defined and a means through which their needs and abilities to advocate for themselves in the larger society could be achieved, to a degree, under their own terms (Beck 2002, 118).

This objective comes through in reading the oral histories of First Nations peoples involved in the formation of the Vancouver Aboriginal Friendship Centre, the Chicago American Indian Centre, the Native American Centre of Toronto, the Phoenix Indian Center, the Oakland Intertribal Friendship House, and other urban Indigenous organisations in settler nation-states. For example, the Phoenix Indian Center was started by American Indians in a downtown storefront in the American city of Phoenix in 1947 and is the oldest non-profit and first American Indian Centre in the United States of America. The Phoenix Indian Center was formed out local Indigenous activism. It was first established as a drop-in centre run by volunteers to assist American Indians coming to Phoenix to look for work under the United States Federal Government's Indian Relocation Act during the 'termination period', which was not dissimilar to Australia's assimilation period. The Phoenix Indian Center became a meeting place, and 
volunteers worked to assist American Indians relocated to Phoenix. It operated on a volunteer workforce for many years. To this day, its mandate is empowerment, cultural enrichment, and community engagement and support services. It now offers workforce development, broad-based social services, educational support, and language and cultural revitalisation. The Phoenix Indian Center has been the cultural heart of this community of association for 73 years now (Phoenix Indian Center 2017).

The American Indian Centre of Chicago was set up in 1953 in response to the relocation program of the 1950s, which brought thousands of American Indians from all over the country to metropolitan Chicago (American Indian Centre of Chicago 2017). As Hautzinger notes:

Chicago was one of those relocation cities, so quite a few Native folks from all across the country ended up here. Our older folks came together and said, 'We need our own place, we need a gathering spot for connecting Natives who are coming to the city. We can provide them with resources, with education, and just be a place where everyone can come and hang out'. So, the Indian Center was born.

(Hautzinger 2018, 1)

The original objective of the Chicago American Indian Centre was 'to help families cope with the transition from reservation to urban life' (American Indian Centre Chicago 2017). Today, it is 'the primary cultural and community resource for over 65,000 [First Nations peoples] in the greater Chicago metropolitan area' (American Indian Centre Chicago 2017).

The Inter-tribal Friendship House was established in 1955 in the city of Oakland in the San Francisco Bay area. Its initial purpose was holding community dinners, drum circles, and pow wows, which were an indispensable part of the resurgence of Indigenous culture in the San Francisco Bay area in the 1970s after the Alcatraz occupation (Lobo 2002). It aimed to nurture a sense of belonging and community among newly relocated First Nations peoples (Lobo 2002). It served as a cultural meeting place for many First Nations peoples, a strong expression of the new intertribal identity that the Intertribal Friendship House was forging (Lobo 2002). It was a place to come together and participate in culture (Lobo 2002).

Likewise, Aboriginal Friendship Centres, such as the Vancouver Aboriginal Friendship Centre Society established in 1963 and the Native Canadian Centre of Toronto established in 1962, were created with a similar purpose. As FitzMaurice, McCaskill, and Cidro note, in providing a range of services to First Nations peoples living in the city, Friendship Centres and other urban First Nations organisations succeeded in creating 'culturally vital' Aboriginal communities that created a sense of place and belonging for Aboriginal people. In addition to the explicit development of Aboriginal peoples' councils as a form of urban self-government, 
these individual organisations provided varying degrees of Aboriginal control within their respective sectors of service delivery (FitzMaurice, McCaskill, \& Cidro 2012, 19).

Urban relocation saw the establishment of urban marae and pan-tribal support groups in the cities of Aotearoa New Zealand, such as Auckland and Wellington (Rosenblatt 2002, 2011; Tapsell 2002). Maori organisations such as the Maori Women's Welfare League and Maatua Whangai (whether by policy or by sheer Aroha) were set up to assist Maori in the cities (Hohepa 1978). Urban relocation also saw the creation of 'Maori enclaves' in city areas, such as West Auckland and Porirua and Otara in greater Wellington (Moeke-Pickering 1996, 6). The Te Whanau O Waipareira was established in West Auckland in the mid-1980s after 'decades of high unemployment, poor housing, low education and other social factors were seriously undermining the potential of urban Maori' (Te Whanau O Waipareira 2017). Today, it provides health, social and family services, legal support and youth justice programs, and alternative education programs for young Maoris, for example (Barnes 2000; Levine 2001; Rosenblatt 2002, 2011; Gagne 2013, 2016).

There are differences in these stories. How First Nations peoples in different localities within and across nations leveraged funds in cities differs from place to place. For example, the fight for operating funds for the Vancouver Friendship Centre was protracted involving 'letter after letter, contact after contact' (Marjorie Cantryn-White, quoted in Lindsay 1998, 29).

Through rebuilding processes, First Nations peoples have been successful at creating models of urban self-determination in cities. Forming new organisations and negotiating new identities in cities are acts of freedom and autonomous acts of self-governing citizenship. These practices existed beyond the binary of the colonial/anti-colonial as exercises of power and resistance, evidencing processes of decolonisation and self-determination (Bargh 2007, 17).

\section{Brief insights about the changing Australian political landscape}

Australian scholarship predominately implies that the formation of First Nations organisations in the cities of Australia was primarily a product of policy and a structural phenomenon. It often overlooks the most important factor, which was the rise of Indigenous social movements and politics, including the Indigenous civil society and community development models that emerged in the cities of the settler-colonial nations of Australia, Canada, Aotearoa New Zealand, and the United States. It often ignores the complex web of sociopolitical relations of that time. It misses the agency of First Nations peoples on the ground. It misses the fact that the formation of First Nations organisations in Redfern and Newcastle predated the legislative instruments of the policy of self-determination. It misses the fact that this was a time in which 
First Nations peoples, environmentalists, and women's groups were creating community-based, not-for-profit, non-governmental advocacy organisations in Australia.

The Australian 1967 federal referendum resulted in a Constitutional amendment giving power to the Commonwealth, concurrent with the states' already existing powers, to make laws concerning Aboriginal people, with the Commonwealth having precedent in the event of inconsistency. Previously Commonwealth responsibility had been limited to the Northern Territory and the Australian Capital Territory. In 1972, the Whitlam government abolished the White Australia policy, and the first Commonwealth Department of Aboriginal Affairs was established, marking the beginning of a new national legislative and policy framework for managing the affairs of First Nations peoples.

The handing back of land to Vincent Lingiari by the Whitlam Labor Government marked the end of the Gurindji strike and a shift in federal policy direction to recognise Aboriginal rights to land through the development of the Northern Territory Land Rights Act 1975 (ALRNT Act) and responded to Aboriginal aspirations of self-determination. The Second Reading speech accompanying the bill through federal Parliament indicates that the objective of the ALRNT Act was to grant traditional First Nations owners inalienable freehold titles to land on reserves and to 'provide machinery for them to obtain title to traditional land outside reserves' (Viner 1976, 3081). The intent of the statute was not merely for traditional owners to use the land for economic and social purposes. However, as stated in the Second Reading speech, it was also to 'allow and encourage Aboriginal peoples in the Northern Territory to give full expression to the affinity with land that characterised their traditional society and gave a unique quality to their life' (Viner 1976, 3082). Vesting inalienable freehold title in land trusts on behalf of the traditional owners of the land via the ALRNT Act was a significant repositioning of First Nations peoples of the Northern Territory and Indigenous land in the settler-state imaginary. The handing back of the land significantly resituated modes of occupancy in the Northern Territory.

The National Aboriginal Consultative Committee (NACC) was established in 1973 under the Labor government with Aboriginal and Torres Strait Islander representatives from 40 electorates representing 800 First Nations communities to advise the Minister on Aboriginal Affairs. Its successor, the Fraser Government, replaced the NACC with the National Aboriginal Council (NAC) in 1977, which had elected state representatives where a ten-member national executive was drawn. The NAC had a prominent role advocating for Indigenous political rights, including the promotion of a treaty agenda in the late 1970s to early 1980s.

The federal Fraser Coalition government ratified the Convention on the Elimination of all Forms of Racial Discrimination and passed national race discrimination laws in 1975. That same year, it also introduced into federal Parliament 
Aboriginal Councils and Associations Bill 1975, as well as Aboriginal land rights laws for the Northern Territory. It was complemented by the Aboriginal development approach of the day promoted through the Department of Aboriginal Affairs and later the Aboriginal and Torres Strait Islander Commission. Policy processes were intended to support the creation of 'autonomous de-colonised self-governing [Aboriginal] entities' so that Aboriginal peoples could manage 'their lives in culturally appropriate ways' (Moran 2012, 1).

The Aboriginal Councils and Associations Act 1976 (Cth), like the NSW Aboriginal Land Rights Act 1983 and later the Aboriginal and Torres Strait Islander Commission Act 1989 (Cth), imposed white systems of governance on First Nations peoples. Government funding and legislation mandated the creation of Indigenous legal entities in the form of cooperatives or not-for-profit corporations. That is, if an organisation wanted to do business with the state or in the state, it needed to be recognised under state law, and the only way to do this was to become a legal entity, such as a cooperative or non-profit corporation. What the Councils and Corporations Act did was to bring corporations to Aboriginal culture and communities in Australia. However, the creation of legal entities afforded a greater degree of self-governance and self-control.

The passing of the Aboriginal Associations and Corporations Act 1976 (Cth) did not suddenly see Aboriginal associations and councils form. Aboriginal activism in urban areas in the Australian state of New South Wales had already led to the establishment of Aboriginal legal services in Redfern (1970) and Newcastle (1974), an Aboriginal medical service in Redfern (1971), and the establishment of the Awabakal Newcastle Aboriginal Cooperative (the Awabakal Coop) in Newcastle (1975), for example.

The requirement to become a legal entity either in the form of a business, not-for-profit corporation, or cooperative was not unique to Australia. While the notion that 'tribes' had an inherent right to govern themselves is at the foundation of their constitutional status in the US, legislation established Indigenous corporations in the 1930s with the passing of the US Indian Reorganization Act of 1934, or the Wheeler-Howard Act, turning reservations into tribal corporations. This law was one of many laws and executive orders that formed the US New Deal Programs following the Depression. The objective of the Act was to provide a means for American Indians to re-establish sovereignty and self-government. However, it imposed a white western style of governance on First Nations tribes in the form of city-council styles of governance. The American Congress sought to 'permit Indian tribes to equip themselves with the devices of modern business organisation, through forming themselves into business corporations' (Section 17, US Indian Business Corporation Act 1934). The purpose of a tribal corporation was to facilitate the economic wellbeing of communities and nations, which was accomplished by creating standards that govern the business entity itself and by relationships between business entities. It became the mechanism through which some tribes successfully achieved tribal sovereignty in the United States. 
From the 1970s onwards, community-based First Nations organisations were created in major cities across Australia such as Sydney, Brisbane, Adelaide, and Newcastle. They were formed in urban localities like Mount Druitt and Dubbo. Individuals, families, and communities were at the centre of this. Organisations became the only structures of urban Indigenous self-governance in Australia to which powers, functions, and resources could be devolved (Moran 2006, 2012). Over the last 40 years, community-based First Nations organisations in cities have gone on to play a distinctive role in Australian society.

\section{The birthplace of Indigenous self-determination in Australia}

[I]t is long past the time when we can make the mistake of perceiving [urban Aboriginal peoples] as vestiges of missives of some more legitimate landbased community. ... They are the source of new forms of culture, association and self-perception - both individual and collective - about what it means to be Aboriginal.

(Andersen \& Denis 2003, 385)

In the wider Australian context, the period of rupture is described by Aboriginal activist James Miller as 'the Awakening' (Miller 1985, 192). Likewise, Professor Heidi Norman, a descendant of the Gomeroi nation, observes that, 'For the new generation of activists, the emerging claim of "Aboriginality" was informed by strategy: Aboriginal peoples emphasised the retrieval of Indigenous tradition and the spiritual rejuvenation as necessary for the rebuilding of an Aboriginal national conscious' (Norman 2015, 17). Norman argues it was 'a kind of radical decolonisation of the mind and self in which many young Aboriginal activists, and their supporters, were in engaged in the 1970s' (Norman 2015, 18). This was not unique to Australia. Maori scholar Manuhuai Barcham describes how the rising urban politicisation entailed the 'imagining of a wider pan-Maori community' (Barcham 2004, 168). Maori scholar Tahu Kukutai states too that 'the plight of racial and Indigenous minorities in the United States, and the subsequent rise of new social movements, including Black Power and Red Power, . . . provid[ed] a backdrop for the rise of Maori' (Kukutai 2013, 317).

Australian historian Russell McGregor describes the late 1960s and early 1970s as a time that witnessed a profound change in the character of Indigenous activism in Australia and that saw the emergence of Aboriginal nationalism, despite Indigeneity and Aboriginality being a social construct of the settlercolonial state, and an associated decline of activist interest in securing Aboriginal inclusion in the Australian nation (McGregor 2009, 343). McGregor argues that Aboriginal nationalism at this time was 'a predominantly cultural nationalism that sought to transcend the colonial subordination of Aboriginal people through a rejuvenation of Aboriginality' (McGregor 2009, 343). A generation of young Aboriginal activists emerged who regarded the whole of Australia as the national 
homeland of Aboriginal people (McGregor 2009, 358). McGregor argues that 'What was new, was the extent to which the recovery of culture was harnessed to the building of an Aboriginal national consciousness' (McGregor 2009, 356).

Cities and non-metropolitan urban areas in Australia, like Newcastle, were important spaces in which the Awakening played out. Cities produced new solidarities (Morgan 2006, 63) in which 'Indigeneity was the common point of discursive and institutional contact' (Maddison 2013, 295). George Morgan argues that there was a critical element of solidarity to this period of rupture. Morgan asserts, 'Solidarity was built on a realisation that what had happened on the reserve was not peculiar but was part of a more generalised set of experiences to those Aboriginal people who had come from elsewhere' (Morgan 2006, 63). In the context of cities, as Sarah Maddison notes, 'The new groups and organisations that formed did not just reflect an "urban Aboriginal" identity, they constructed it' (D'Arcus 2010, 1245-1246, 1252 cited in Maddison 2013, 295).

The inner western Sydney suburb of Redfern was an important site of urban Aboriginal social mobilisation in Australia. Aboriginal activists agitated for Aboriginal housing and legal and medical services. Local police were 'enforcing a curfew from $9.30 \mathrm{pm}$ onwards targeting Aboriginal people in inner Sydney' and targeting particular areas where Aboriginal people were congregating, blocking off streets, and arresting Aboriginal people (Aboriginal Legal Service NSW/ACT Ltd 2017). The origins of the first Aboriginal Legal Service came out of this moment:

On Thursday and Saturday nights when Aboriginal people congregated at the Clifton and the Empress Hotel, the police often blocked off the streets of Redfern with police bull wagons a half hour before closing time. They moved into the hotels and forced Aboriginal people out onto the streets. Police officers would then indiscriminately arrest individual Kooris who then spent the night in the cells. Kooris who were arrested were later charged under the Summary Offences Act 1970 with a basic trespass offence, charged with drunkenness, offensive behaviour and offensive language.

(Aboriginal Legal Service NSW/ACT Ltd 2017, 1)

Then law student Peter Tobin approached then professor of law, later Supreme Court judge, Hal Wootten 'to attend meetings with this group of Aboriginal people to see what help and advice he could give' (Aboriginal Legal Service NSW/ACT Ltd 2017, 1). The history of the Aboriginal Legal Service describes this as follows:

Justice Wootten enlisted the aid of several prominent lawyers to attempt to change State Government policy towards Aboriginal people, in particular, the police activities around the inner city area. They attended hotels on Thursday, Friday and Saturday nights as observers to ascertain and establish the truthfulness of the claims being made by Aboriginal people, and whether their presence there would deter police from arresting large numbers of Aboriginal 
people arbitrarily. What they observed confirmed the degree of abuse and intimidation by the police.

(Aboriginal Legal Service NSW/ACT Ltd 2017, 1)

It was this series of events that culminated in 'Aboriginal activists and lawyers set[ting] up the Aboriginal Legal Service in Redfern in 1970, staffed by volunteers' (Aboriginal Legal Service NSW/ACT Ltd 2017, 1). In early 1971, the Aboriginal Legal Service in Redfern 'received a government grant of $\$ 24,500$ for the salaries of a full-time solicitor, a field officer and a secretary' (Aboriginal Legal Service NSW/ACT Ltd 2017).

In 1971, the first community-controlled Aboriginal medical service was established in Redfern as the Aboriginal Medical Service Cooperative Ltd. It was established by a small group of concerned Aboriginal people and their supporters as a small shopfront clinic with a volunteer doctor and Koori nurse/ receptionist (Foley 1991, 4). As Morgan writes, 'in 1973 Aboriginal activists and supportive local priests conducted a campaign to counteract the problem of homelessness in Redfern [which] led ... to the federal Labor government purchasing a section of terraced housing around Everleigh Street, that later became known as The Block' (Morgan 2006, 59). The Block 'was allocated for Aboriginal housing and was eventually owned and managed by the Aboriginal Housing Company' (Anderson 1993, 2000, cited in Morgan 2006, 59).

This 'became the heart of the Indigenous community in Sydney' (Morgan 2006, 61). As the once state and now federal Labor politician and Wiradjuri woman Linda Burney observed in a statement to the New South Wales Parliamentary Standing Committee in 2004, the Redfern-Waterloo area became 'the birthplace of self-determination in Australia' (Burney 2004, cited in Morgan 2006, 63).

\section{Coming together: the formation of the Awabakal Aboriginal Cooperative in Newcastle}

[I]t's a resettlement area and people have come here for opportunities.

(transcript 2)

[T] here [were] a whole host of people. Aunty Gloria Smith, Uncle Bill Smith, Aunty Dorothy Wotherspoon, Uncle Ron Gordon, Uncle Ray Kelly, Aunty Colleen Perry, Aunty Louise Campbell, Uncle Jim Wright, Uncle Bill Jonas, Uncle Kevin McKenny. There's a host of names and too many to mention but all have played a role - Uncle John Heath - all have played a role at various stages in the evolution of the [Awabakal Cooperative]. I don't think any of them ever anticipated that it would be the size it is today. I think the evolution of the organisation is a testament to the board members of the time and the CEOs of the time. [They] started - set the course, I guess, of the organisation, especially in those early formative years of the organisation.

(transcript 57) 
What was happening in other local contexts occurred in Newcastle. Read together, interviews with local Kooris reveal that urban Indigenous social organisation and community building is expressed as agency, and as something more than resistance. In a sociological sense, it is a form of social organisation, coming together to improve First Nations peoples' 'purposive ability to influence their own social world' (Petray 2012, 1). It evidences the 'carving out of a degree of local autonomy' (Yashar 2005, 63). Local Kooris defined selfdetermination as the pursuit of social and cultural development. It was a reconfiguring of the terrain of self-determination in cities that differed to the coupling of self-determination from land for First Nations peoples who had been dispossessed but remained on homelands. However, there was also a strong notion of territoriality. That is, the creation of a new community of association in the city was the creation of an Indigenous space as 'extraterritorial' in that local Kooris were exercising their rights beyond the boundaries of their own First Nations. Like many others, they sought to transcend the colonial subordination of First Nations peoples through the expression of an Indigenous cultural nationalism. However, self-determination was grounded in the Awabakal nation where they now lived. Pre-contact history and the sacredness of the land as Awabakal nation is significant to the grounding of this new relational community in place. Heather Howard makes a similar observation about the Toronto Aboriginal community (Howard 2004).

One prominent local Koori activist describes this as occurring 'especially through the $70 \mathrm{~s}$, and I think - and through the $80 \mathrm{~s}$ and parts of the $90 \mathrm{~s}-\mathrm{I}$ think there was this concept of unity within the community and that we need to be united people in order to advance the cause' (transcript 57). This theme of 'community' - unity, working together, and community-led empowerment - is evident in the following interview extracts:

I think there's probably been a strong history of political activism and some really strong leaders in this community, that got together to make a change themselves.

(transcript 1)

[F]rom [Aboriginal] workers from BHP donating money each week and stuff to form Awabakal, just as always committed to their heritage, to work, to their families.

(transcript 22)

That is one of the things that Aboriginal people have been very good at. We do not always get along, but when it comes down to the crunch, all of us are black (sic), and we will all stick together when it counts. So, that concept of unity still exists. 
As Heather Howard observes in the context of the community building in Toronto and Susan Lobo observes in the context of community building in San Francisco Bay, community is built as a relationship space (Howard 2004, 3). Kooris describe community building as a social process of coming together around a shared sense of belonging within society. Community building has a cultural, social, as well as a political purpose - it is about unifying and working together to bring about social change. Community is imagined and constructed (Howard 2004). It is grounded in place in Awabakal nation.

Kooris relocated from other First Nations - such as Dunghutti, Gamilaroi, Wonnarua, and Wiradjuri nations. Kooris shared a deep epistemological empathy and appreciation of the effects of the imposition of 'Aboriginality' as a socially constructed settler category. Its imposition entailed everyday life experiences, across nations and peoples, with colonisation, dispossession, child removal, racism, discrimination, and exclusion from the state.

Paul Collis, who spent much of his younger adult years in Newcastle, refers to this process entailing the sharing of memory, the telling of stories, and the conscious claiming and naming of an identity (Collis \& Webb 2014, 504). Like elsewhere, Indigenous identity in Newcastle was a rich, mixed tapestry (Turner et al. 2008). As one local Koori notes, 'We're all Aboriginal, but we all have many languages, many Dreamings, the whole thing. ... The biggest quality we have in here is our knowledge of who we are, knowledge of community and communication being open and being very transparent' (transcript 55). Local Kooris are a 'dynamic and vibrant people who are truly a "Mixed Mob"' (Mixed Mob Exhibition, Newcastle Regional Museum 2001). Kooris who shared similar knowledge systems, kinship arrangements, ways of doing business, and ways of being in the world unified as self-determining people to seek solutions to their own problems (Heritz 2012, 43). This model of self-governance and community control emulates what Stephen Cornell identifies as forms of nation building (Cornell 2002); the intent has been to increase the capacity for self-governance, self-determination, and community development, taking authority away from the state and replacing it with community-control. Koori leaders served as nation builders in the city.

\section{The creation of the Awabakal Aboriginal cooperative}

[G]oing back to - and it is probably the late 70 s early 80 s where there was an opportunity to set up Aboriginal organisations. Our intentions were good, and it was about setting up organisations that add value to community.

(transcript 58)

Many people were working together to try and do a lot of better things for people or get better outcomes for Aboriginal people.

(transcript 17) 
Since its inception, more than 50 persons have served on its Board of Directors. Early directors include Clem Sands and his sister Lillian, Aunty Amy Ridgeway who had lived at Platts Estate, Jack Thorpe who fought at the Stadium and his wife June, Ted and Dot Wotherspoon, Robert and Shirley Smith, Zelma Moran, Victoria Matthews, and George and Ann Ritchie. Victoria Matthews and Zelma Moran were later to work for the co-op as secretary and field officer respectively. Among the other early field officers were Amy Trindall, John Ferguson, Wayne Nean and George Griffiths. Wayne was instrumental in the setting up of the Hunter Aboriginal Children's Service in 1984, while George was a member of the NSW Aboriginal Lands Trust before the handing over of reserves to communities through the NSW Aboriginal Land Rights Act 1983.

You had blackfellas and whitefellas (sic) coming together and saying, 'We have to do something about the disadvantage that is occurring here in the Aboriginal community within Newcastle'. Very humble beginnings and I guess, probably unique, in the fact that it was, I guess, the first test of genuine reconciliation, the fact that you have blackfellas and whitefellas (sic) coming together to establish an organisation.

(transcript 57)

Civil disobedience, social and political movement formation, and unionism were all part of Newcastle's political landscape in the 1970s. While what happened in Newcastle reflected the agendas of the national Indigenous resurgence movement, the city became a significant locality in which Kooris consciously engaged in resurgent Indigenous world-making, making space for themselves, and re-weaving the fabric of Indigenous society. The Smith brothers, Dot and Ted Wotherspoon, Aunty Zelma Moran, and other local Kooris who were 'deeply involved in local community affairs through the Newcastle Aboriginal Advancement Association' (Maynard 2001, 73) got together to push for social change for local Kooris living in the greater Newcastle region (as far north as Karuah and as far west as Toronto that is, within the boundaries of Awabakal nation). The Smith brothers and their company Smith's General Contracting had played a significant role in advancing the social and economic situation of Kooris. They were involved in the development of 'infrastructure that would help meet their needs, including the retention of some traditional practices' (Heath 1998, 66). John Maynard comments that 'Bob and Bill Smith and Bob Sampson were instrumental and heavily involved in establishing a local branch of the Aboriginal Legal Service and initiating the Newcastle All Blacks football team' (Maynard 2001, 74).

Indigenous community building in Newcastle was not the 'catalytic effect' of what Max Weber (1978) described as charismatic leaders (Purdue 2001, 2215). Young Koori activists who directed their attention to community building did not only project themselves into roles of Indigenous leadership. A group of young innovative and successful Kooris 'came together for the greater good of the 
community' (transcript 2). Coming together involved the formation of an urban Indigenous social and political movement - a movement for rights, recognition, reconciliation, and social change. It was a group of Aboriginal activists who drove and brought about significant change locally. However, they also came together with non-Indigenous activists from the Labor and union movement - members of the Newcastle Trade Hall Council (NTHCAAC 1968, A7046 ii) - to form an Aboriginal Advancement Society in Newcastle and later the Awabakal Cooperative, the first First Nations organisation in Newcastle alongside state-wide Indigenous services, such as Aboriginal legal services and Durangaling and Kirinari Hostel, which were already in operation in Newcastle. The Awabakal Cooperative was the first community-owned and run First Nations organisation. Influential Kooris became leaders and later Elders, creating a new network of leaders that took on critical roles within First Nations organisations. They established cultural legitimacy among local Kooris. Local Koori leaders created powerful social networks including connections with other communities in the region and local, state, and federal bureaucrats and officials. They led through an approach to decisionmaking based on the consensus of the community, managing factional interests, and pursuing a common good. These young and innovative Kooris moved into a normative role in Indigenous society as community leaders, caring for their new associational community, creating consensus, and earning the respect of this newly formed community. Their role, and those who followed, as Indigenous community leaders was earned through their demonstrated commitment to the community and the movement and through their various altruistic endeavours and innovative projects that aimed to transform the conditions of local Kooris.

It was in this early moment of local activism and social mobilisation that the Awabakal Newcastle Aboriginal Cooperative (the Awabakal Cooperative) was established in 1975. Its founding president was Bill Smith, who was later elected to the National Aboriginal Conference in 1981 and served as its New South Wales state chairperson (Maynard 2001, 74). The use of the name Awabakal acknowledged the nation on which the organisation was formed. It also signalled that Kooris who relocated to the Awabakal nation had come together on Awabakal nation and that they would respectfully follow the traditions of the nation on which they now lived. The Awabakal Newcastle Aboriginal Cooperative was not established as an Aboriginal company or business under the Aboriginal Councils and Association law. It was first registered as a Community Advancement Cooperative Society in 1977 and later as an organisation under the Charitable Collections Act (Heath 1998, 66). The term cooperative was used to reflect the fact that the organisation was a cooperative or an autonomous association of First Nations peoples united voluntarily to meet their common economic, social, and cultural needs and aspirations through a jointly owned and democratically controlled community collective. As Heath notes, 'The decision to register under the Cooperative Societies Act was based on the feeling that the spirit of cooperative societies better-reflected philosophies of traditional [Aboriginal] societies than that of other incorporated bodies which reflect competition' (Heath 1998, 66). Its registration 
reflected the fact that it emerged from the endeavours of local activism and its communal intent. It was formed from local donations, such as 'workers from BHP donating money each week' (transcript 22). Its purpose was 'to provide empowerment to the Aboriginal communities of the Hunter' (transcript 59). The Awabakal Cooperative was at the service of this newly formed community of association, conducting the political work on behalf of it from below. It created a space for meaningful participation. It also created a space for local Kooris to further anchor themselves in Indigenous culture and ways of knowing and being. It maintained Indigenous socio-cultural practices within the local Koori community. Social and cultural activities created a sense of community and belonging. It was a social movement, a political and economic advocacy organisation, community gathering place, and cultural hub - all at once.

The Awabakal Cooperative was a community-owned and run organisation. Its formal incorporation and governance structures not only reflected this arrangement but also reflected the fact that it was community-based cooperative. It is membership-based. While assimilation moved forward through the replication of white organisational models, the Awabakal Cooperative's sound governance structure not only conformed to a western incorporated associations model but also drew on Indigenous cultural and governance principles. Local Kooris, who came from many different nations, had created a new relationship based on a shared cultural nationalism. It was reflected in the governance structure of the organisation. So too was the fact that their cultural geography centred around Awabakal nation, which created new obligations and responsibilities. It was this cultural nationalism, but also the cultural geography, that became a basis for rebuilding governance structures locally through community-based organisations. The Awabakal Cooperative's formal incorporation and governance structures reflected this arrangement with local Kooris elected by the Awabakal Cooperative membership, holding positions on its board. It also reflected formalised western structure of separation of powers between the elected board and the Chief Executive Officer, annual general meetings, etc. The Chief Executive Officer and the Board were elected by the community, who were members of the organisation, and took on a leadership and representative role within the community. It was also very much a political role with wider mainstream society. As a former chief executive officer of the Awabakal Cooperative noted in an interview, the establishment of the Awabakal Cooperative and later community-based organisations was about 'being equal to the white people and running [our] country, organisations, programs and services the way we want to' (transcript 64).

It differed too from the Aboriginal Christian Cooperative Movement, which led to the establishment of various cooperatives on missions in New South Wales and Queensland, as well as the Tranby Aboriginal Cooperative College in Glebe in 1958 (Loos \& Keast 1992). It differed too from the political Aboriginal Associations formed earlier to progress the rights of Aboriginal people, such as the Aborigines Protection Association (sic) an all-Aboriginal body formed in 1937 with the three aims of full citizenship rights for Aboriginal Australians, Aboriginal 
representation in Parliament, and the abolition of the New South Wales Aborigines' Protection Board (sic).

The establishment of the Awabakal Cooperative functioned as a way of building community locally and creating a level of social cohesion among First Nations peoples living in Newcastle. Those elected to the position of Chief Executive Officer and the Board built a sense of community ownership of the Awabakal Cooperative, and the programs and services it created, through close engagement with the local community in the development of the organisation and its programs and services. Many interviewees make the point that 'that's one thing that Aboriginal people have been very good at' (transcript 2), creating 'a really good base here ... a social base within our community' (transcript 58). Bridging social capital is mobilised through Aboriginal committees too. It is reflected in the following interview extract.

They have been the middle man between the Aboriginal community and governments. To get communication from the Aboriginal community back to the government on what they want. To take the core business of government and communicate that to the Aboriginal community. They're kind of that glue and that communication channel. They connect the community to the government.

(transcript 56)

Along with the required meetings of the organisation, there were regular community meetings to engage the community in identifying the function of the Awabakal Cooperative. The local Aboriginal community identified the need for an Aboriginal medical centre, skills training, and preschools (Hall \& Jonas 1985a, 1985b). The community-identified activities of the Awabakal Cooperative were mostly cultural and social economy activities.

Like elsewhere, the Awabakal Cooperative aimed to sustain culture and to recuperate and revitalise what had been lost. It delivered cultural activities to the community, which included Awabakal Cultural Camps for young people. The diversity of its cultural and social agenda is documented in the minutes of the first Awabakal Cooperative Annual General Meeting in 1977. In that meeting the community identified the following objectives: hold a cultural camp for 9- to 15-year-olds at Rathmines the week before Christmas; establish an Aboriginal Health Centre; reclaim the Sacred sites at the Watagans and establish a permanent reserve and cultural centre; establish an Aboriginal Pre-school; obtain an Aboriginal legal-service field officer to work from the Cooperative; set up a loaning and Homework Centre that would include such teaching programs as the teaching of the Awabakal dialect; establish our own club; and, set up our own housing co-op. (Awabakal Newcastle Aboriginal Co-operative 1977).

Local Kooris did not have statutory property rights, and their revenue-raising capacity for community social and cultural development was highly restricted 
(Dodson \& Smith 2003). While community donations allowed for basic programs, the Awabakal Cooperative relied on voluntary staff and needed funding for space. The only viable funding option was to seek out government support. State and federal Indigenous policy and funding arrangements from the 1970s offered a mechanism for achieving a separate Indigenous domain; the policy of the day encouraged control in local and community government. Government funding was a way of circumventing mainstream social, educational, employment, housing, and health services, providing culturally centred programs and services, and 'doing business the Aboriginal way' (transcript 53). The Awabakal Cooperative 'seized the moment' (transcript 17), securing grants under different government schemes. The Awabakal Cooperative's first government grant was under $\$ 15,000$. The grant was to carry out a cultural awareness program in Newcastle.

As one interviewee notes, 'I think because of the community involvement, the Aboriginal community involvement, . . . that's been successful and I think that's because we have been working together' (transcript 17). It is further illustrated in the following account given by local Worimi man, Dr. Bill Jonas, who was also the second federal Aboriginal and Torres Strait Islander Social Justice Commissioner.

The Awabakal Cooperative successfully submitted for funds and, more importantly, successfully used them. It meant that further applications for funds were successful. It also meant that the Awabakal Cooperative began to show evidence of successful growth, it established excellent relations with the New South Wales Ministry for Aboriginal Affairs and the Commonwealth Department of Aboriginal Affairs [at that time]. Both of these Governments were bodies looking for successful role models, and both were willing to back winners. Awabakal began to attract resources and projects, and the process of successful development became cumulative. Success breeds success!

(Jonas 1991, 77)

As Jonas notes, in those days, state and Australian governments were willing to back winners, and successful development attracted resources and projects. In social capital terms, success also bred trust, enhancing 'linking social capital' (Putnam 2000). The Awabakal Cooperative established a high degree of 'competence trust' among governments, government departments, and funding bodies to the point that 'government departments wanted to give Awabakal projects because the management and the governance was good' (transcript 55).

Successive CEOs and board members were attuned to the conditions of the bureaucratic field. For example, Jonas comments on how Jim Wright, the first Chief Executive Officer of the Awabakal Cooperative, who later went on to successfully establish Yarnteen and Yamalong, built, accumulated, and mobilised 
communal social capital for the community, and thereby earned respect and recognition locally:

One of Jim Wright's strengths and one who had positive effects for the Co-op was his awareness of, and willingness to participate in, the broader Aboriginal community and movement. It earned him wide respect and enabled him to tap into events, which benefited the Co-op. For example, at the time when Awabakal was establishing a medical centre, he was a member of the National Aboriginal and Islander Health Organisation (NAIHO), and he was the inaugural Convener of their Aboriginal Health and Resources Committee. When the Co-op was developing expertise in sites survey work, he was a member of the NSW National Parks and Wildlife Service Advisory Committee and a member of the Central Region Site Committee. He was Chairperson of the Newcastle Aboriginal Home Care Service Committee, Chair of the Hunter Aboriginal Inter-Agency Group, and has served on both Aboriginal Cricket and Football Committees from their inception.

(Jonas 1991, 76)

Successive CEOs have had what Purdue describes as both transformational and transactional leadership qualities. They were competent 'in the acquisition and management of resources, and goodwill by their attributes of vision, commitment and energy [transformational leaders] ... [and] they earned the goodwill and trust of local Aboriginal people [transactional leaders]' (Purdue 2001, 2215).

Successive CEOs and board members have had to navigate the many shifts in policy at the state and federal levels, including the waxing and waning support at both levels and attempts to box in their identity and function from the very early days. Resistance through protest was used as a powerful political tool to influence government. For example, the New South Wales Department of Aboriginal Affairs changed its policy in 1977, as it would repeatedly do on successive occasions over the next 40 years. At this moment, the Department attempted to define Awabakal Aboriginal Cooperative's mandate, which was established in 1975 to meet the everyday economic, social, and cultural needs and aspirations of local First Nations peoples through a jointly owned and democratically controlled community collective, like that of an Aboriginal referral agency. It has the power to do so because of the dependency the Awabakal Cooperative had on it for funding. In its response to an application for funding, it stated that it was rejecting the application because the Department was no longer funding 'pure welfare activities'. The Department noted in its response that: 'You are an Aboriginal referral agency'. In this policy moment, the Department attempted to define and box in the societal function of the Awabakal Cooperative.

Again, in 1980, when the New South Wales Department of Aboriginal Affairs cut the funding of the Awabakal Cooperative, it 'closed its office doors' and began operations from a tent in Civic Park opposite Newcastle City Hall (Beale 1980). The NSW Department of Aboriginal Affairs had previously agreed to a budget of $\$ 46,000$ for $1980-1981$, but it was cut to $\$ 13,000$ (Beale 1980,1). The main 
reason for the protest was that the cut in funding would severely restrict the Awabakal Cooperative five-year development plan for 'setting up a permanent cultural centre, a medical service, a preschool, and an Aboriginal housing company' (Dawson 1980, 1). This protest saw funding successfully reinstated. The Awabakal Cooperative continued to engage in political protest.

By the mid-1990s, the Awabakal Cooperative had 'several hundred members' and 'its wages and salary expenditure was over $\$ 1.1$ million and ... spent in the local area ... making an important contribution to the Newcastle economy' (Heath 1998, 68). The Awabakal Cooperative was at the centre of resurgent activities directed at building the political and cultural identity and wellbeing of local Kooris. Events such as

National Aboriginal Week activities, especially the NAIDOC Ball; providing children's Christmas parties; running sports days; sponsoring coaching clinics; liaising with the Newcastle Aboriginal Support Group; speaking at a whole host of forums; lobbying politicians; and sponsoring Aboriginal sports-people and students who travel within Australia and overseas.

(Jonas 1991, 68)

While it had started as a gathering place for Kooris relocating to Newcastle, the social innovation and entrepreneurship of its successive CEOs and boards saw it go on to create the Awabakal Medical Centre, Awabakal preschools, and early childhood and childcare services. It became the glue that held the community together, and its communal cohesiveness has enabled it to leverage resources from governments to build Indigenous social infrastructure locally. It organises and sponsors community culture, wellbeing, and sporting events. It provides social housing, transport, and Elders services. In 2012, the Awabakal Cooperative became 'the single largest employer of Aboriginal people in Newcastle and the Hunter region. ... A hundred and twenty-seven staff. Ninety-seven per cent of the workforce is Aboriginal' (former CEO Awabakal Ltd). The Awabakal Cooperative went on to become 'a leading example of Aboriginal community power in Australia' (Awabakal Ltd 2016). Today it has an annual turnover of $\$ 10$ million (Awabakal Annual Report 2014).

\section{References}

Aboriginal Legal Service NSW/ACT Ltd (2017). 'Arbitrary Curfews and Discrimination', www.alsnswact.org.au/arbitrary_curfews_and_discrimination.

Ahmet, R (2001). 'Taking Back Responsibility and Restoring Aboriginal Capacity in Cape York Peninsula', Opening address to the Northern Summit 11 September, Cape York Partnerships, Queensland.

American Indian Centre of Chicago (2017). 'History', https://aicchicago.org/history/.

Andersen, C \& Denis, C (2003). 'Urban Natives and the Nation: Before and After the Royal Commission on Aboriginal Peoples', The Canadian Review of Sociology and Anthropology, Vol. 40, pp. 373-390. 
Awabakal Annual Report (2014). www.acnc.gov.au/charity/040be78b68da9fce67c071d64 faa12e4\#financials-documents.

Awabakal Ltd (2016). 'History', www.awabakal.org/our-past-and-future/history-video.

Awabakal Newcastle Aboriginal Co-operative (1977). Awabakal Newcastle Aboriginal Cooperative Annual General Meeting Minutes, Newcastle, NSW.

Barcham, M (2004). 'The Politics of Maori Mobility', Population Mobility and Indigenous Peoples in Australasia and North America, pp. 163-183.

Bargh, M (2007). Resistance: An Indigenous Response to Neoliberalism. Wellington: Huia Publishers.

Barnes, H M (2000). 'Kaupapa Maori: Explaining the Ordinary', Pacific Health Dialog, Vol. 7, No. 1, pp. 13-16.

Barras, B (2004). 'Life Projects: Development Our Way', in In the Way of Development: First Nations Peoples, Life Projects and Globalization. London: ZED Books, pp. 47-51.

Beale, B (1980). 'Awabakal to Close Office: Co-op Rejects Cut in Budget', Newcastle Morning Herald, 16 July.

Beck, D (2002). 'Developing a Voice: The Evolution of Self-Determination in an Urban Indian Community', Wicazo Sa Review, Vol. 17, No. 2, Sovereignty and Governance, II (Autumn), pp. 117-141 (25 pages).

Blaser, M (2004). 'Life Projects: First Nations Peoples' Agency and Development', in Blaser, M, Feit, H \& McRae, G (eds.), In the Way of Development: First Nations Peoples, Life Projects and Globalization. London: ZED Books, pp. 23-43.

Chudacoff, H, Smith, J \& Baldwin, P (2016). The Evolution of American Urban History, 8th Edition. New York: Routledge.

Collis, P \& Webb, J (2014). 'The Visible and the Invisible: Legacies of Violence in Contemporary Australian Aboriginal Contexts', Journal of Australian Studies, Vol. 38, No. 4, pp. 490-503.

Cornell, S (1984). 'Crisis and Response in Indian-White Relations: 1960-1984', Social Problems, Vol. 32, No. 1, pp. 44-59.

Cornell, S (2002). 'Nation-Building and the Treaty Process', Indigenous Law Bulletin, Vol. 5, No. 17 , p. 7.

Curthoys, A, Genovese, A \& Riley, A (2008). Rights and Redemption: History, Law and First Nations Peoples. Sydney: UNSW Press.

Dahl, J (2012). The Indigenous Space and Marginalized Peoples in the United Nations. New York: Palgrave Macmillan.

D'Arcus, B (2010). 'The Urban Geography of Red Power: The American Indian Movement in Minneapolis-Saint Paul, 1968-70', Urban Studies, Vol. 47, No. 6, pp. 1241-1255.

Dawson, D (1980). 'Aboriginal Co-Operative Mounts Protest for Funds', Newcastle Morning Herald, 30 July.

Dodson, M \& Smith, D E (2003). 'Governance for Sustainable Development: Strategic Issues and Principles for Indigenous Australian Communities', Discussion paper No. 250, Centre for Aboriginal Economic Policy Research, The Australian National University.

Escobar, A (1992). 'Reflections on "Development": Grassroots Approaches and Alternative Politics in the Third World', Futures, Vol. 24, No. 5, pp. 411-436.

FitzMaurice, K, McCaskill, D \& Cidro, J (2012). 'Urban Aboriginal People in Toronto: A Summary of the 2011 Toronto Aboriginal Research Project (TARP)', in Newhouse, D et al. (eds.), Well-Being in the Urban Aboriginal Community: Fostering Biimaadiziwin, 
a National Research Conference on Urban Aboriginal People. Toronto: Thompson Educational Publishing.

Fixico, D (1990). Termination and Relocation: Federal Indian Policy, 1945-1960. Albuquerque, NM: University of New Mexico Press.

Foley, G (1991). Redfern Aboriginal Medical Service 1971-1991: Twenty Years of Community Service. Redfern, NSW: Aboriginal Medical Service Co-operative.

Furlan, L M (2017). Indigenous Cities: Urban Indian Fiction and the Histories of Relocation. Nebraska: University of Nebraska Press.

Gagne, N (2013). Being Māori in the City: Indigenous Everyday Life in Auckland. Toronto: University of Toronto Press.

Gagne, N (2016). 'The Waxing and Waning of the Politics of Authenticity: The Situation of Urban-Based Māori Through the Lens of Municipal Politics', City \& Society, Vol. 28, No. 1, pp. 48-73.

Hall, M R \& Jonas, W J (1985a). On the Fringes of Newcastle Society. Newcastle, NSW: Awabakal Newcastle Aboriginal Co-operative Limited in association with the NSW Ministry of Aboriginal Affairs.

Hall, M R \& Jonas, W J A (1985b). Almost Out of Sight, Almost Out of Mind: Aboriginal Reports of Aboriginal Basic Needs New South Wales 1983. Geography Department, University of Newcastle, Newcastle, Australia.

Harvey, D (2008). 'The Right to the City', The City Reader, Vol. 6, No. 1, pp. 23-40.

Hautzinger, D (2018). 'We're Still Here: Chicago's Native American Community', WTTW Chicago, https://interactive.wttw.com/playlist/2018/11/08/native-americans-chicago.

Havemann, P (1999). First Nations People's Rights in Australia, Canada and New Zealand. Oxford: Oxford University Press.

Heath, J (1998). 'Muloobinbah: The Contributions of Aboriginal People to the Resources of the Hunter Region', in Hunter, C (ed.), Riverchange. Newcastle: Newcastle Region Public Library.

Heritz, J (2012). The Inclusion of Atypical Minorities in Public Policy: Urban Aboriginal Peoples in Canada and Travellers in Ireland. PhD Dissertation, McMaster University, http://digitalcommons.mcmaster.ca/opendissertations/7308/.

Hill, G \& Cooke, M (2014). 'How Do You Build a Community? Developing Community Capacity and Social Capital in an Urban Aboriginal Setting', Pimatisiwin, Vol. 11, No. 3, pp. 421-432.

Hohepa, P (1978). 'Maori and Pakeha: The One-People Myth', in King, M (ed.), The Mauri Ora: Aspects of Maoritanga. Wellington: Methuen.

Howard, H A (2004). Dreamcatchers in the City: An Ethnohistory of Social Action, Gender and Class in Native Community Production in Toronto. Toronto: University of Toronto.

Jonas, W (1991). Awabakal, Bahtabah, Biripi, Worimi: Four Successful Aboriginal Organisations. Newcastle: University of Newcastle.

Keenan, S (2014). 'Moments of Decolonization: Indigenous Australia in the Here and Now', Canadian Journal of Law and Society, Vol. 29, No. 2, pp. 163-180.

Kukutai, T (2013). 'The Structure of Urban Maori Identities', in Peter, E \& Andersen, C (eds.), Indigenous in the City: Contemporary Identities and Cultural Innovation. Vancouver: UBC Press, pp. 311-333.

Levine, H B (2001). 'Can a Voluntary Organisation Be a Treaty Partner? The Case of the Whanau O Waipareira Trust', Social Policy Journal of New Zealand, Vol. 17, pp. 161-170. 
Lindsay, W G (1998). A History of the Vancouver Aboriginal Friendship Centre in an Age of Aboriginal Migration and Urbanization. Vancouver: UBC Press.

Lobo, S (2002). Urban Voices: The Bay Area American Indian Community. Arizona: University of Arizona Press.

Loos, N \& Keast, R (1992). 'The Radical Promise: The Aboriginal Christian Cooperative Movement', Australian Historical Studies, Vol. 25, No. 99, pp. 286-301.

Maddison, S (2013). 'Indigenous Identity, "Authenticity" and the Structural Violence of Settler Colonialism', Identities: Global Studies in Culture and Power, Vol. 20, No. 3, pp. 288-303.

Marcuse, P, Brenner, N \& Mayer, M (2012). Cities for People, Not for Profit: Critical Urban Theory and the Right to the City. New York: Routledge.

Mayer, M (2017). 'Whose City? From Ray Pahl's Critique of the Keynesian City to the Contestations Around Neoliberal Urbanism', in Marcuse, P, Brenner, N \& Mayer, M (eds.), Cities for People, Not for Profit: Critical Urban Theory and the Right to the City. New York: Routledge.

Maynard, J (2001). 'Muloobinbah (Newcastle) an Aboriginal Industrial Presence: Past and Present', Journal of the Royal Australian Historical Society, Vol. 87, No. 2.

McGregor, R (2009). 'One People: Aboriginal Assimilation and the White Australia Ideal', History Australia, Vol. 6, No. 1, pp. 03.1-03.17.

Miller, J (1985). Koori: A Will to Win. Sydney: Angus \& Robertson.

Mixed Mobs Exhibition (2001). 'Aboriginal Dreamtime of the Hunter Region Mixed Mobs Exhibition', Aboriginal collections held by the University of Newcastle.

Moeke-Pickering, T (1996). Maori Identity Within Whanau: A Review of Literature. Hamilton: University of Waikato.

Moran, M F (2006). Practising Self-Determination: Participation in Planning and Local Governance in Discrete Indigenous Settlements. PhD Thesis, University of Queensland, Brisbane.

Moran, M F (2012). 'Bridging the Gap of Indigenous Development', The Drum, ABC, 30 May.

Morgan, G (2006). Unsettled Places: Aboriginal People and Urbanisation in New South Wales. Adelaide: Wakefield Press.

Norman, H (2015). 'What Do We Want?': A Political History of Aboriginal Land Rights in New South Wales. Canberra: Aboriginal Studies Press.

Norris, M J, Clatworthy, S \& Peters, E (2013). 'The Urbanization of Aboriginal Populations in Canada: A Half Century in Review', in Peters, E \& Andersen, C (eds.), Indigenous in the City: Contemporary Identities and Cultural Innovation. Vancouver: UBC Press, pp. 29-45.

NTHCAAC (Newcastle Trades Hall Council Aboriginal Advancement Committee) (1968). Constitution and Policy Statement [ca 1968], A7046(ii). Newcastle: University of Newcastle Archives Section.

Peters, E \& Andersen, C (2013). Indigenous in the City: Contemporary Identities and Cultural Innovation. Vancouver: UBC Press.

Petray, T L (2012). 'Can Theory Disempower? Making Space for Agency in Theories of Indigenous Issues', Theorising Indigenous Sociology: Australian Perspectives Workshop Proceedings. From: Theorising Indigenous Sociology: Australian Perspectives Workshop, 22-29 November 2012, Brisbane, QLD, Australia, pp. 1-6.

Phoenix Indian Center (2017). 'Phoenix Indian Center', https://phxindcenter.org/.

Pollak, M (2016). 'Reflection on Urban Migration', American Indian Culture and Research Journal, Vol. 40, No. 3, pp. 85-102. 
Purdue, D (2001). 'Neighbourhood Governance: Leadership, Trust and Social Capital', Urban Studies, Vol. 38, No. 12, pp. 2211-2224.

Putnam, R D (2000). Bowling Alone: The Collapse and Revival of American Community. New York: Simon \& Schuster.

Rosenblatt, D (2002). 'Titirangi Is the Mountain: Representing Maori Community in Auckland', Pacific Studies, Vol. 25, No. 1, pp. 117-140.

Rosenblatt, D (2011). 'Indigenizing the City and the Future of Maori Culture: The Construction of Community in Auckland as Representation, Experience, and Self-Making', American Ethnologist, Vol. 38, No. 3, pp. 411-429.

Rosenthal, N G (2012). Reimagining Indian Country: Native American Migration and Identity in Twentieth-Century Los Angeles. Chapel Hill, NC: University of North Carolina Press.

Ryks, J, Howden-Chapman, P, Robson, B, Stuart, K \& Waa, A (2014). 'Maori Participation in Urban Development: Challenges and Opportunities for First Nations Peoples in Aotearoa New Zealand', Lincoln Planning Review, Vol. 6, No. 1-2, pp. 4-17.

Ryks, J, Pearson, A \& Waa, A (2016). 'Mapping Urban Māori: A Population-Based Study of Māori Heterogeneity', New Zealand Geographer, Vol. 72, No. 1, pp. 28-40.

Sissons, J (2005). First Peoples: Indigenous Cultures and Their Futures. London: Reaktion Books.

Tapsell, P (2002). 'Marae and Tribal Identity in Urban Aotearoa/New Zealand', Pacific Studies, Vol. 25, No. 1, pp. 141-171.

Te Whanau O Waipareira (2017). 'Kia Pū te Wai o Pareira: Catalysts of Whānau Health and Wellbeing in West Auckland', Te Whanau O Waipareira, www.waipareira.com/wpcontent/uploads/2017/11/W1.Kia_Pu-te_Wai_o_Pareira_\%E2\%80\%93_Catalysts_of_ Wh_nau_Health_and_Wellbeing_in_West_Auckland.pdf.

Tomiak, J (2011). Indigenous Self-Determination, Neoliberalisation, and the Right to the City: Rescaling Aboriginal Governance in Ottawa and Winnipeg. PhD Thesis, Faculty of Graduate and Postdoctoral Affairs, Carleton University, Ottowa, Canada, https:// curve.carleton.ca/system/files/etd/33cddc38-7654-41ed-bde5-f80d1afe5a32/etd_pdf/ 2ad9fc09862ae03cd51050e1210684ee/tomiak-indigenousselfdeterminationneoli beralization.pdf.

Turner, N J, Gregory, R, Brooks, C, Failing, L \& Satterfield, T (2008). 'From Invisibility to Transparency: Identifying the Implications', Ecology and Society, Vol. 13, No. 2, pp. 7-21.

Viner, I (1976). 'Second Reading Speech, Aboriginal Land Rights (Northern Territory) Bill 1976, House of Representatives', Hansard, 4 June, pp. 3081-3084.

Walker, R C (2005). 'Social Cohesion? A Critical Review of the Urban Aboriginal Strategy and Its Application to Address Homelessness in Winnipeg', The Canadian Journal of Native Studies, Vol. 25, No. 2, pp. 395-416.

Walker, R C (2006). 'Searching for Aboriginal/Indigenous Self-Determination: Urban Citizenship in the Winnipeg Low-Cost-Housing Sector, Canada', Environment and Planning A: Economy and Space, Vol. 38, pp. 2345-2363.

Weber, M (1978). Economy and Society: An Outline of Interpretive Sociology. Berkley, CA: University of California Press.

Yashar, D J (1999). 'Democracy, Indigenous Movements, and the Postliberal Challenge in Latin America', World Politics, Vol. 52, No. 1, pp. 76-104.

Yashar, D J (2005). Contesting Citizenship in Latin America: The Rise of Indigenous Movements and the Postliberal Challenge. Cambridge: Cambridge University Press. 


\title{
Indigenous social economies \\ hidden in plain sight
}

\author{
Organisations, community \\ entrepreneuring, development
}

The original intent of the Awabakal Cooperative was more around preservation of culture. It was more about social activities and cultural activities and crafts and things like [that] - it was a way of preservation.

(transcript 57)

Organisations have a leading role in facilitating Aboriginal resurgence and recognition. They need to lead the way. . . - we need to be able to lead the way and have a forum for sharing and this facilitating Aboriginal recognition; it's really important that we are able to do that because we want to be passing on our culture to our children and children's children. It is really important to have that opportunity. People's potential is closely linked to their identity, confidence, and ability to be reaching that potential comes out of a community, and a community that's given an opportunity to filter out into having a place where they can be seen and recognised for their contribution.

(transcript 56)

We all have a commonality in what we are here for and what we are trying to achieve. I think that makes a real difference. No one is here because they just need a job, and this is the job that was available. They are here because it is about capacity building within their community.

(transcript 14)

On visiting the Native Canadian Centre of Toronto in September 2019, I was struck by its similarities to the Awabakal Cooperative in Newcastle. The building it is located in is a heritage building constructed in 1928 as McNicol Hall, Toronto Bible College. It is in a prime location in the city. It is in the same precinct as the University of Toronto and a short walk from the University of Toronto's Department of Sociology. Like the Awabakal Cooperative, the heritage façade of the building conceals a highly successful Indigenous community institution and enterprise created in 1962 by First Nations peoples for all First Nations peoples living in Toronto. 
It is Toronto's oldest Indigenous community institution and enterprise - one of the original Friendship Centres in Canada. Like the Awabakal Cooperative, the Native Canadian Centre of Toronto has been an incubator for Toronto's Indigenous social infrastructure, such as Anishnawbe Health, Aboriginal Legal Services of Toronto, Native Child and Family Services, Wigwamen Housing Corporation, and more (Native Canadian Centre of Toronto 2020). Sixty years on, it is a highly successful community cultural centre that does business the Indigenous way, making an essential contribution to the Indigenous care economy in Toronto.

Like the Awabakal Cooperative, the Native Canadian Centre of Toronto began as a meeting place and cultural centre for First Nations peoples relocating to the city (Obonsawin \& Howard-Bobiwash 1997). The Native Canadian Centre of Toronto and the Awabakal Cooperative are more than membership based - they are meeting places. For example, the Meeting Place documents how a 'tightknit' community was formed in Toronto around the Native Canadian Centre of Toronto (Bobiwash 1997, 3) Like the Awabakal Cooperative, the Native Canadian Centre of Toronto became 'the center or metaphorical town-square of the community' (Howard 2004, 102). Like the Awabakal Cooperative, its first programs were directed at cultural resurgence in the city; it provided social, recreational, cultural, and spiritual services (Native Canadian Centre of Toronto 2020). Historically, like those who worked in the Awabakal Cooperative, those who worked in the Native Canadian Centre of Toronto saw themselves as "political leaders in the "continued growth and sustainability of the community"' (Howard 2004, 96). As Howard notes, 'the Centre is important symbolically as the "heart" or "mother" of organisations that form the infrastructure of what is called "the Toronto Native community", (Howard 2004, 102). It is 'referred to as "home" for many people' and 'there is a strong sense of community ownership of the centre' (Howard 2004, 102). They are the 'homes' and 'the heart' of community in the city. There is a strong sense of community ownership over the Native Canadian Centre of Toronto and the Awabakal Cooperative. Their purpose being to serve community needs.

Today, while there are similarities and differences in the programs and services they provide, community and culture are at the heart of the activities and programs that take place within the Awabakal Cooperative and the Native Canadian Centre of Toronto. The Native Canadian Centre of Toronto provides free daytime meals for First Nations peoples who are on social services and/or homeless. It has a large commercial kitchen and dining room. On Friday mornings, Elders gather at the Awabakal Cooperative to connect and engage in traditional art and craft, yarning over activities like basket weaving. The Native Canadian Centre of Toronto has weekly classes in Kanyenkeha (Mohawk) Language, Oneida Language, and beginner Anishnawbemowin Language classes. The Native Canadian Centre of Toronto has a weekly pow wow dance class where participants learn various styles of pow wow dancing and their meaning and purpose. The Awabakal Cooperative and Native Canadian Centre of Toronto have Men's Circles and Women's Circles. 
Unlike the Awabakal Cooperative, the Native Canadian Centre of Toronto offers a program called The Indigenous Marketplace, which is a community economic development initiative that pairs small business and entrepreneurial training, growth supports, and infrastructure with the intent of building a stronger, more diversified Indigenous economic presence in the city of Toronto (Native Canadian Centre of Toronto 2020). Yartneen Aboriginal and Torres Strait Islander Corporation, which formed out of the Awabakal Cooperative, was established to provide this support to Kooris in the City of Newcastle. Also unlike the Awabakal Cooperative, the Native Canadian Centre of Toronto has a youth program. Wandiyali Aboriginal and Torres Strait Islander Corporation was initially established to develop Indigenous youth programs for local Kooris in the City of Newcastle in 1998.

The history of the two organisations is not dissimilar. Neither are they dissimilar to that of the Vancouver Friendship Centre (Lindsay 1998; Reynolds 2015; Langford 2016), the Intertribal Friendship House in San Francisco Bay (Lobo 2002), the American Indian Centre in Chicago (La Pier \& Beck 2015), the Phoenix Indian Center (Sage 2016; Martinez 2016), the Manukau Maori Authority (Ryks et al. 2014; Gagne 2013, 2016), and Te Whanau O Waipareira (Barnes 2000; Levine 2001; Rosenblatt 2002; Tamihere 2015; Gagne 2016) in Auckland. I have drawn parallels from visits to the Vancouver Aboriginal Friendship Centre in 2013, the Phoenix Indian Center in 2014, the Manakau in Auckland in 2015, and the Oakland Intertribal Friendship House in 2019.

First Nations peoples came together to make a difference in the lives of other First Nations peoples, creating meeting places and nurturing Indigenous culture in the creation of grassroots First Nations organisations to assist First Nations peoples who had relocated to the city to adjust to their new lives. First Nations peoples were not merely engaged in building civil societies, but in activating Indigenous agency and forming civil society institutions through activism and grassroots movements. Indigenous grassroots movements came together to form communities of association, social relations, networks, and institutions focused on the reinvigoration of culture and cultural identity and the creation of culturally vibrant meeting places that supported relocated First Nations peoples. Political and material conditions were necessary, but Indigenous social relations, governance, language, culture, and cultural identity were embedded in First Nations organisations and the programs and services created. Community development fostered active Indigenous participation whereby First Nations peoples worked together to improve the social, cultural, economic, and political conditions of First Nations peoples in cities.

In this chapter, I focus on Indigenous practice and governing established through community-owned and community-based First Nations organisations. It is important to distinguish Indigenous practice and governing through communityowned and community-based organisations from the wider urban Indigenous governance that has come to operate in urban contexts in the present moment. The chapter explains how the creation of First Nations organisations in cities was 
a means of establishing Indigenous self-government and autonomy in cities. Urban Indigenous governance itself is a distinct form of Indigenous governance. Katherine Graham defines urban Indigenous governance as the 'institutions, services and political arrangements dedicated to meeting and representing the needs and interests of the urban Indigenous population' (Graham 1998, 2). This model extends beyond the function of organisations established by First Nations peoples in cities to include state and non-state actors. I deal with this complexity later in the book. For now, though, I focus on the intent of the models of Indigenous selfgovernment and the intent of Indigenous self-government established through the process of organisation building that led to the building of Indigenous social infrastructure in cities. All told, Koori leaders have formed a system of governing grounded in a subjectivity emulated as ethics of collective Indigenous social and cultural wellbeing. Like Anderson, Honig, and Peredo observe elsewhere, First Nations peoples have built a culturally grounded foundation, while simultaneously improving the social and economic circumstances of many Kooris (Anderson, Honig, \& Peredo 2006, 56).

By the turn of the 21 st century, a concentration of service, advocacy, and socialchange organisations existed in many cities. Indigenous community development had turned to a form of communal entrepreneuring in Australia, Canada, Aotearoa New Zealand, and the United States. Loose confederations of multiple Indigenous communities, social relations, health organisations, employment and training programs, educational resources, transportation agencies, justice groups, cultural clubs, and recreational utilities and assets were created. Many settler cities now have the most developed Indigenous community infrastructure within settler nation-states. Thirteen Indigenous organisations were created in the city of Newcastle; 16 in the suburb of Redfern in Sydney's inner west; 20 each in the cities of Brisbane, Chicago, and the region of Western Sydney; 25 in Vancouver.

There is a complexity to the creation of First Nations organisations in settlercolonial cities not previously explored or understood. Indigenous community entrepreneuring in the city of Newcastle was directed at restoring and healing Indigenous lifeworlds, addressing the complex economic, racial, social, and cultural disadvantage local Kooris experience in this city. Organisation building was also a means for revitalising local Indigenous practices, including culture, knowledge, and language, as well as improving the wellbeing of local First Nations peoples. Indigenous culture, ways of doing business, governance, ownership, and control are at the centre of Indigenous community development. It is an example of bottom-up, community-driven, and controlled development and community agency grounded in Indigenous cultural and social norms and ways of doing business. The nuances and complexity behind the creation of a loose alliance of community-based First Nations organisations in Newcastle is the focus of Chapter 4.

Relational autonomy allowed First Nations organisations to pursue a path to community development on behalf of First Nations peoples. The governance structures of urban First Nations organisations were designed to be responsive to the demands and expectations of First Nations peoples. They became the mediators 
between First Nations peoples and local, state, and federal governments, and their agendas extended beyond service delivery to advocating for structural change and a politics of recognition. While service delivery has been an essential part of the solution, the bigger picture was Indigenous community development and resurgence in cities. First Nations organisations facilitated community efforts for community development, self-determination, and local governance in the city. As I discuss in Chapter 5, First Nations organisations were a vehicle through which First Nations peoples endeavoured to access their right to the city.

A strong social fabric, community building, and place-based economy of exchange and reciprocity were facilitated and nurtured by Koori leaders. This enabled Kooris to achieve a form of Indigenous community development and self-determination in this city. The formation of a loose alliance, or what Arthur observes as a 'loose confederation', of First Nations organisations led to the creation of a social economy of care, education, and training (Arthur 1994; HowardWagner 2017). Local Kooris had successfully tackled an extraordinary range of needs: providing Indigenous medical, dental and other associated health services; educating children through preschool and young adults through an Indigenous institute at the local university; providing human services, such as day care, housing, transport for Elders, meals on wheels, out-of-home care children's services, job training, job placement, alcohol and drug services, and family violence prevention; strengthening cultural life through various community activities, men's programs, women's programs, and Elder's programs; and promoting Indigenous arts and cultural activities generally.

\section{Beyond invisibility: Indigenous governing and institution building}

I was involved in a lot of cultural camps. Awabakal Cooperative was wonderful in the cultural opportunities they offered kids. . . I I can see the value in young people, in particular, being able to be proud of their identity and how that builds their confidence, just opens the door for them to do well.

(transcript 56)

Like Maraes in Aotearoa, Indian Centres in the US, and Friendship Centres in Canada, the Awabakal Cooperative acted as 'the heart of the community, pumping blood through the veins and arteries, maintaining and upholding Indigenous identity' (Puketapu-Dentice, Connelly, \& Thompson-Fawcett 2017, 11). It created a refuge for local Kooris and allowed them a space to be themselves (PuketapuDentice, Connelly, \& Thompson-Fawcett 2017, 11).

The Awabakal Cooperative was the only community-based First Nations organisation in Newcastle for many years. At first, it was a meeting place, hosting community cultural activities and linking Kooris relocating to Newcastle with services. It slowly developed a range of social and health services in response to what local 
Kooris identified were their needs in this city, expanding with the establishment of the Awabakal Medical Centre, Awabakal Childcare Centres and Preschools, and later the Awabakal Disability Service.

At first, the Awabakal Cooperative operated alongside other local First Nations organisations established under national Indigenous and state initiatives. The Aboriginal Legal Service also established a branch in Newcastle in the early 1970s. The Kirinari Aboriginal Secondary Students Hostel and Durungaling Aboriginal Tertiary Students Hostel were established in the early 1970s by the Aboriginal Children's Advancement Society. They later came under the auspices of the national body known as Aboriginal Hostels Limited. The local Aboriginal hostels provided accommodation and support to young Aboriginal males from remote localities on sporting scholarships studying at Newcastle's high schools, and later university. The Wollotuka Institute at the University of Newcastle came out of the 1970s and aimed to have 1,000 Aboriginal teachers by 1990 (transcript, Founder of the Wollotuka Institute at the University of Newcastle).

Bob Morgan and I, who were then on NAEC, visited many universities. Offering - we came with a bag of Commonwealth monies and encouraged universities like this one to get involved. Primarily to establish an enclave they were referred to in those days. So Wollotuka was an enclave. That was somewhere where Aboriginal students could feel safe, secure and well supported on campus. It's grown from that development. We've just celebrated 30 years. It didn't happen overnight. We stood on the shoulders of many before us to get to the stage, where we've got this wonderful building, the wonderful commitment of the university. Hopefully this year, we'll go close, if we don't get 1,000 Aboriginal students enrolled at the university. In terms of growth, an amazing growth process. During that process, we moved to - as many other universities did - not just being a support program, but we started to create our own educational delivery. So, we created jobs for lecturers, et cetera. We have a very strong grow-your-own quality.

(transcript, Founder of the Wollotuka Institute at the University of Newcastle)

The Wollotuka Institute, for example, went on to become an important 'home' for Koori higher education in the city, encouraging young people to finish year 12 and get a tertiary education. Many local Kooris also got a degree as matureage students. It established an Elders-in-Residence program involving eight local Koori Elders. The Elders-in-Residence were those foundational leaders involved in bringing this new community of association together. The Wollotuka Institutes present home is the Birabahn building, which was purposely built and, like Yallarwah Place, is architecturally designed with the roof span as the wings of the Eagle Hawk in commemoration of Birabahn (meaning Eagle Hawk), a wellknown Awabakal man who tutored the first missionary Reverend Threlkeld. The Eagle Hawk is a significant Awabakal totem. 
Its connection to community and place has been critical to Wollotuka's success. It has also created trust among local Kooris in the higher education system:

The connection of community to the government or the government institutions really makes a difference. For the university that's been integral to their growth over the last 30 years, the connection to community and the community interest in the growth of success in Aboriginal education. So, from other - I think that the community stuff has been the strongest. Because from that community then you get community encouraging participation for other young people as well. So, you have that generational trust in the education system. So, therefore, our Elders or our older generations will be saying to the younger people you should go to the university in Newcastle. You should take on further education because it's really valuable. So, we've been able to develop a culture of the valuing of education and I think that's another strong point in success. We have the largest numbers of Aboriginal students in any university in Australia.

(transcript 59)

The Awabakal Local Aboriginal Land Council was established in 1984. Although its Chief Executive Officer (CEO), board, and members are local Kooris, it sits under the NSW Aboriginal Land Rights Act 1983. It has a specific statutory purpose: to make claims to acquire vacant Crown Land under the Act, as well as to protect Awabakal cultural heritage and sites within its specific jurisdictional boundary, which does not cover the whole of Awabakal nation. It is to play a vital role in creating economic opportunities for Aboriginal people within its boundary (NSW Ombudsman 2011, 49) and to be a local agent of economic development (Rowse 2012, 76).

The Hunter Aboriginal Children's Service was established in 1984 as a subproject of the Aboriginal Legal Service. It was set up under a 12-month Commonwealth Employment Program grant to promote the care and fostering of Aboriginal children in Aboriginal homes.

The Awabakal Cooperative went on to become a local 'hub' (Jonas 1991) or 'incubator' (Smith 2008) for significant initiatives because governments would only invest in new programs if they were under its umbrella (Jonas 1991). While governments wanted the Awabakal Cooperative to be a 'one-stop-shop' for Indigenous social and health service delivery, community leaders did not wish to create a centralised council or body that concentrated and unified power. Instead, local Koori leaders set about creating a dispersed organisational and governance model through the establishment of a 'loose confederation' (Arthur 1994) or loose alliance of First Nations community corporations and enterprises that operated as self-governing institutions. They created an 'elaborate network of organisational governance and senior leaders whose focus was on community service delivery, economic development, cultural identity, language and land' (Smith 2008 , 4). A loose confederation or alliance of community-owned organisations 
created diverse employment opportunities and pathways for local Kooris. Different members of the community became involved in different aspects of Indigenous-driven community development. They sat on boards or managed different community-owned organisations. It allowed local Kooris to access specialised culturally centred, culturally safe services and programs well-targeted to their needs. It worked to mitigate experiences of racism often associated with accessing mainstream programs and services. It was the innovative phase of community development.

This process of organisation building among key Kooris leaders is expressed in the following interview extract:

Yarnteen came out of the Awabakal Cooperative. The then administration for Awabakal Cooperative, Jim Wright, is the chairperson of Yarnteen. At the time, Awabakal was very successful and had 12 projects, one hub administration. I was working with the administrator at Awabakal back then as project coordinator, so I was overseeing the projects and communicating back through to him. Government departments wanted to give Awabakal projects because the management and governance were good. However, it got really heavy with projects, and they wouldn't give enough percentage to maintain a hub that could oversee all of that, I guess, reporting and governance across all the projects. So, what happened was six of the projects were trained up in governance and financial management. They had their own boards, and they became their own individual organisations. A lot of those organisations still exist today, and Yarnteen was one of the organisations started because where Awabakal was culture and welfare focused; the need was identified for that self-determination around steering our own training and our own employment opportunities and our business inclusion. So that's why, I guess, Yarnteen was registered in 1991. It was to enhance that economic inclusion of Aboriginal people and to do that, that was done by employment training and business development. Yamuloong is a social enterprise which gives people the opportunity for employment, training and brings our community together. It's a community-based centre that also is about sharing without the wider community, corporate and schools. Yarnteen also has a commercial arm so Yarnteen's independent with government funding through its business operations, investment. So, I guess it's a little bit unique in that regard, and they set some precedent for how Aboriginal organisations can become, I guess, independent and self-sufficient while still running programs that, yeah and meet the needs of our community.

(interview, former CEO of Yarnteen)

Organisations created an elaborate web and a kind of bottom-up government where rights and interests, decision-making powers, leadership roles, responsibilities, and accountabilities spread across different organisations. Organisations shared political power and authority, decision-making processes, roles 
and responsibilities, and mutual accountability to the broader local Koori community. Their mandate came from the community, and they represented the community in interactions with local, state, and federal governments and departments.

First Nations organisations took on complex social, political, and economic functions locally. Local leaders engaged in creating innovative Indigenous corporations and enterprises that, in turn, created Indigenous community infrastructure, services, and programs. The corporations and community enterprises established played a significant governance function, took on the role of community political representation and advocated for a right to the city, and engaged in cultural resurgence (see Chapter 5).

What facilitated community development was the creation of a national statutory authority and peak representative body for Aboriginal and Torres Strait Islander peoples, known as the Aboriginal and Torres Strait Islander Commission (ATSIC) in the early 1990s, as well as ad hoc state funding that provided for the establishment of organisations such as the Awabakal Aboriginal Cooperative (Awabakal Co-op). In later years, First Nations organisations accessed funding through the Aboriginal Development Commission, ATSIC, the federal Wage Pause Program, the Community Development Employment Program (CDEP), and later the NSW Two Ways Together Regional Action Plan for the Hunter, for example. Some organisations were in a position to build up assets, create social enterprises, and partner with or apply for funding from private enterprises such as Yarnteen Limited (Smith 2008; Howard-Wagner 2017). ATSIC funded Aboriginal development and infrastructure initiatives, which saw the creation of Yarnteen Limited in 1991, Muloobinba Aboriginal Corporation in 1991, Wandiyali Aboriginal and Torres Strait Islander Corporation in 1998, and Miromaa Language and Technology Centre in 2002.

Yarnteen Aboriginal and Torres Strait Islander Corporation came out of the Awabakal Cooperative in 1991. From the onset, the business of Yarnteen was distinct from that of the Awabakal Cooperative. The name Yarnteen is an Awabakal word meaning 'all/everybody'. Yarnteen's vision and objectives focus solely on the enhancement of employment, training, and enterprise development opportunities for Kooris and on helping them prosper within the whole community system (Yarnteen 2020). Yarnteen went on to initiate several communitybased services and programs, including cultural maintenance activities and sporting, youth, and women's programs. From the beginning, Yarnteen saw the need to become a player in the mainstream economy of our region (Yarnteen 2020). It was an important strategy to ensure the sustainability of the organisation and to create long-term employment for local Kooris. Yarnteen Limited replicated more of a venture-capital-supported business than a not-for-profit charity organisation that served First Nations peoples. It has taken pride in its contribution to community, commercial and social entrepreneurship, and asset building, which came out of the Commonwealth Development Employment 


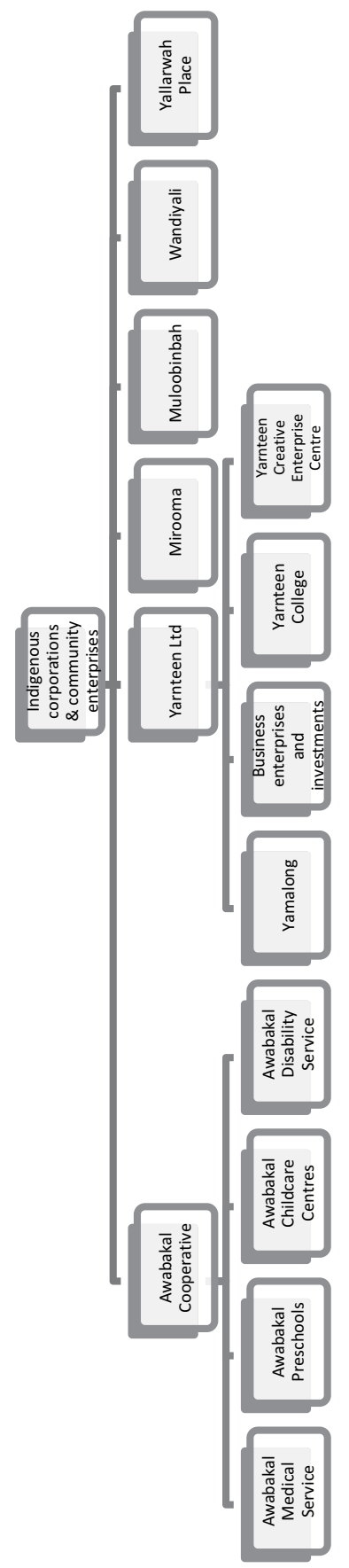


Program (CDEP) (Howard-Wagner 2017). This attitude is reflected in the following interview extract.

One of the best projects that ever came about was CDEP, Commonwealth Development Employment Program, [work for the dole]. Initially, Yarnteen was not interested because a section of our board felt that it was just another prop. Once we investigated it, Yarnteen took it on because we could see that there was so much flexibility. There was capital input. There was money towards each - for participants to just work two days for the goal.

My role back then was employment manager. I could have a young person come in to say I'd like to be a florist. So, I can take that two-day incentive or that two day's work for the dole; I'd use that as an incentive to an employer. I'd say to that employer, let us build a training plan, you've got to add at least a third day and a training plan, and it's got to be a pathway with an outcome for this person. We'd be like - we'd be the employer. We'd pay their wages; we'd bill the employers. So, we had programs like that happening everywhere. We had projects with John Hunter Hospital, maintenance with parks, Housing Commission, cleaning out of the houses. We had a landscape company, building company. We had over 240 participants at any one time. We did not ignore our other organisations in the area. We would have agreements and partnerships with land councils where they might take six people from their community to be on a project.

The CDEP also gave capital expenditure, so we were able to go, well this is what equipment is needed for that particular business opportunity, so we'll invest in that. I guess it was great - used correctly CDEP was an excellent program, and it was the thing that made the difference for Yarnteen in going forward and being wise about, from there, having opportunity to be a part of the regular business opportunities available. Banking loans to purchase premises, to house these programs and to build up an asset base. Where partnership was not only mainstream but also government departments. Yamuloong was built, and people got their trades so started to do first-year trades, do landscaping and seeding of indigenous plants.

We ran kitchens where they were doing hospitality, catering and product we had a business - I forget the exact name for it, but the ideas were all around bush tucker. So, the participants would come in and learn about business plans and how do you establish a business, let's actually do it and run the business from here.

We always see new governments, new policy, new . . When the CDEP closed, it was disappointing because we could see the great success and the opportunity. ... We were particularly, I guess, smart in - it's like being smart in the good times so we were quite well established, and we were able to continue to operate. 
The then administrator for Awabakal Cooperative, Jim Wright, became the first Chairperson of Yarnteen, holding that position for over 25 years. Yarnteen went on to operate several business enterprise development initiatives, including Port Hunter Commodities (a commercial storage facility at Kooragang) and Yarnteen College Incorporated (vocational education and training) (Yarnteen Annual Report 2019, 2). It too has incubated several community enterprises (Smith 2005, 3) such as Yarnteen Creative Enterprises. It also acquired a large well-appointed, renovated building to accommodate Yarnteen Creative Enterprises in March 2006. The Yarnteen Creative Enterprises Centre was funded by the Commonwealth Department of Education, Science and Training - VET Infrastructure for First Nations peoples program; the Department of Transport and Regional Services Regional Partnership program; and the Microsoft Unlimited Potential program, as well as substantial capital funds provided by Yarnteen (Yarnteen 2020). Yarnteen Creative Enterprise Pty Ltd is registered as a Public Benevolent Institute and is a Cultural Diversity Awareness Training Centre (Yarnteen Annual Report 2019 and ACNC Charity Register). In 2007, Yarnteen transferred the incorporation of Yarnteen Aboriginal and Torres Strait Islander Corporation to Yarnteen Limited. Today, around 10 per cent of its revenue comes from grant funding only (Yarnteen Annual Report 2019, 16). Yarnteen Ltd was thus highly successful in leveraging CDEP funds (Smith 2008; Howard-Wagner 2017).

This is consistent with Di Smith's more detailed discussion of the formation and governance of Yarnteen as an enterprise (Smith 2005). Yarnteen 'successfully leveraged various forms of capital (e.g. institutional, human, cultural and natural)' (Smith 2005, 2). Capital created assets, business enterprises, and community social and cultural enterprises. For example, the Chief Executive Officer of Yarnteen noted that

Yamuloong is a social enterprise which gives people the opportunity for employment, training and brings our community together. It's a communitybased centre that also is about sharing without the wider community, corporate and schools. Yarnteen [an economic enterprise] and is the commercial arm so Yarnteen's independent with government funding through its own business operations, investment.

(transcript former CEO, Yarnteen)

It was also successful in securing a Microsoft grant under the Microsoft Unlimited Potential community program to provide increased access to ICT training and develop software programs that support the reclamation, revitalisation, and recording of Indigenous languages (interview, CEO Miromaa). It led to the establishment of the Miromaa Aboriginal Language and Technology Centre (interview, CEO Miromaa). Miromaa started on two small grant programs - a language recovery program and an associated cultural program. It has gone on to become a separate organisation in its own right, and one that is an internationally 
recognised success - its founder and CEO has created an international Indigenous language database that is now used by Indigenous communities around the world.

Community-owned organisations were created to meet the cultural, social, economic, and political needs of Kooris. Robert Smith, who had taken on the role of Managing Director of the Awabakal Medical Service, was a strong advocate for the improvement of the provision of Aboriginal health services in the region (Maynard 2001). Yallarwah was one of his many achievements in this regard (see also Chapter 5). In fact, Yallarwah Place at Hunter Hospital (created in 1999) was even referred to as 'Uncle Bob's place'.

\section{Koori leadership: 'coming together for the greater good of the community'}

Look I think when you've got organisations like the Awabakal Coop. I think when you've got that strong network of Aboriginal organisations. Providing transport, getting people to services. I think having the Wollotuka Institute and the programs that Newcastle Uni has run. Because there are a number of Aboriginal students who are graduating from Newcastle Uni and they're getting out there into teaching and health and other professions. I think that's been very positive. . . . Having Aboriginal doctors has made a difference. . . . There is an Aboriginal specific out of home care service. In terms of trying to ensure that cultural connections are maintained [for Aboriginal children] . . the, another thing at the moment is, the work of some of the land councils has been very positive.

(transcript 3)

I think a major contributor [of local resurgence and success] would be actually the establishment of such organisations as the Aboriginal Cooperative. They have the Elders program, the Aboriginal medical service, the Aboriginal Medical Centre and lots of stuff, so a lot of associated programs with that; the Aboriginal Co-op and the Aboriginal Lands Council, so they've been a leading sort of organisation at the front that has been more or less a flagship as to addressing all these issues and that sort of stuff on Closing the Gap.... You have got a fair few organisations that have sort of stood up and said, yeah, look, this is what we want to do.

(transcript 2)

We have been one of the major forerunners in looking at the future and knowing what we want and how we were going to get there. ... It goes back to the way we work together and the way we plan together.

(transcript 6)

That's what people want to do around here, I think. They want to be a part of building on what's been started and supporting community. 
What's the best outcome for a community, being able to work together to bring a good outcome for Aboriginal people is the main thing.

(transcript 56)

Key Koori leaders played a vital role in setting up First Nations organisations such as Yarnteen Limited, Wandiyali Aboriginal and Torres Strait Islander Corporation, and Miromaa Aboriginal Language and Technology Centre. Local Kooris became members of self-governing institutions, electing the boards and setting organisational mandates. This entailed the devolution of local power to this loose alliance of First Nations organisations. Appointed Chief Executive Officers and elected board members were formally and informally accountable to local Kooris, who were constituents or members of these organisations. The Chief Executive Officers and Chairs of Boards negotiated directly with politicians, bureaucrats, and funders on behalf of local Kooris, and as such, self-governing institutions took on a representative role in the local area and in relations with the three levels of government in relation to Indigenous governance in the city and further afield to the level of the state of New South Wales and federally. It was a groundbreaking period of innovation and success. Local Kooris describe those involved in institution building as leaders who utilised their epistemological understanding of the world as a means to create community cohesion and belonging. Kooris leaders are also described as not only 'com[ing] together for the greater good of the community', but also 'working together'. Working together has factored significantly in the community's capacity.

Koori leaders were agents of innovative social change, and they proficiently mobilised the community in pursuing enterprising endeavours, creating and building new First Nations organisations. Importantly, First Nations organisations were not only intrinsically communal enterprises with an underlying mandate of bringing the community together but also cultural institutions that embed culture in the way they do business. They were not merely providing culturally appropriate social and health services for local Kooris. There was a cultural complexity that epistemologically and ontologically distinguished them from white mainstream organisations. A cultural complexity manifested as a form of cultural resurgence that activated the capacity to practise one's culture in everyday contexts such as 'doing business the Aboriginal way' (transcript former CEO Yarnteen), particularly the regenerating of specifically Indigenous practices and values.

Community leaders earned their authenticity through accumulating communal social capital in their transactions with their own community (Purdue 2001, 2218). They stepped into critical social roles within Indigenous society, demonstrating good community governance practices, earning the goodwill and trust of local First Nations people. They achieved goodwill by operating within an Indigenous ethics of care, meeting their cultural obligations to this new associational community. Leaders endeavoured to transform the conditions of local Kooris. Leaders built and strengthened associational bonds, creating the glue that held this 
associational community together (Putnam and Feldstein (2003). Their status as leaders also became a resource used to leverage their community's social capital in dealings with peak Aboriginal bodies, governments, government departments, and funding bodies, which in turn maintained their leadership status (Purdue 2001, 2218). Working together and having high levels of bonding social capital has factored significantly in the community's capacity to build relationships with government departments.

Koori leaders took on a critical function in representing Kooris living in this city in government at the local, state, and federal level. Senior position holders represented their organisations, and the local community, on various committees from state policy committees to local government committees. Chief Executive Officers and Chairs of community-owned First Nations organisations in this city became the legitimate representatives of Indigenous interests. They would regularly be found in attendance at official city events and in conversation and having the ear of the Mayor; local councillors; local, state, and federal members of Parliament; and local clergy. It meant that CEOs and Chairs of Boards held a level of power in their relationships with politicians, bureaucrats, and funders. They were quoted often in the media. They were given a seat at the table in discussions about local and state Indigenous governance matters. However, they also delegated this power to other position holders within the organisation, including program managers and other board members. Elders too took on important representative roles in relations with the three levels of government. Power was not concentrated in one organisation or one individual but dispersed among several organisations and individuals. So, when Newcastle City Council first formed its Indigenous Advisory Committee, there were representatives from all organisations on this committee along with several Elders. This also took place in the day of the Aboriginal and Torres Strait Islander Commission (ATSIC), and local Kooris elected an ATSIC Regional Councillor. It was a highly effective model of Indigenous governance in this city.

By 2002, there were 13 Indigenous organisations managed by and employing local Kooris. Six had been established locally. The other seven organisations had been established under the umbrella of state or national Indigenous statutory bodies: the Awabakal Local Aboriginal Land Council, the Aboriginal Legal Service, the Aboriginal Tenancy Advice Service, Durungaling Hostel, Kirinari Hostel, the Hunter Aboriginal Children's Service, and the Aboriginal Employment Service. These seven worked closely with community-based First Nations organisations and employed local Kooris, including in senior positions. By 2010, in the context of urban Indigenous governance in this city, these organisations sat alongside various government departments that oversaw Indigenous programs and services in this city, including the Newcastle regional branch of the New South Wales Department of Aboriginal Affairs and Aboriginal Housing and the federal department of Families, Housing, Community Services and Indigenous Affairs.

There is an important distinction, though, between Indigenous governing and Indigenous governance in this city as it looks today. Community and culture 
lay at the heart of Indigenous governing and organisation building. Community informed the rules and values about the 'right way' of exercising power and governing. There was a cultural legitimacy in the governance arrangements including the rules, structures, and processes of First Nations organisations. Organisations embodied Indigenous values and norms about how power and authority should be shared and put into practice. While Kooris created strong social networks and engaged in sharing knowledge, urban Indigenous governance in this city (in terms of the space in which community-based First Nations organisations; local, state, and federal bodies; and mainstream organisations work together to deliver services to First Nations peoples or engage First Nations peoples in relevant Indigenous business of the city) has gone on to emulate western models of governance.

\section{Indigenous community entrepreneuring}

First Nations organisations are communal social structures, and the social fabric of the community is the vehicle for entrepreneurship (Peredo \& Chrisman 2010; Hindle \& Lansdowne 2005; Hindle \& Moroz 2010; Pearson \& Helms 2013). Community entrepreneuring created a separate Indigenous domain within civil society - a domain that is separate from the state (Cho 2006, 38). The following interview extract, which is indicative of a theme running through all transcripts, demonstrates the specific entrepreneurial endeavours of organisation building and how this extends to program development and delivery within organisations.

So, there's that entrepreneurial stuff; I can make a difference by forming this corporation and we can do something together about drug and alcohol abuse, about domestic violence, about cultural heritage, and talk about the cultural heritage and language and history and that kind of stuff. That's all real strong. There is a real strong basis, so that we can tap into that strengthbased approach.

(transcript 7)

That is, local Kooris use the terms entrepreneuring and enterprise frequently to explain the actions of organisation building by local Kooris. Community entrepreneuring is an act, rather than an entity.

We create! First Nations peoples - local First Nations peoples come into the area, who were quite entrepreneurial, developed employment prospects [for First Nations peoples] in that regard.

(transcript 58 - emphasis added)

Aboriginal entrepreneurs and enterprises are part of the community.

(transcript, General Manager Indigenous organisation) 
The term entrepreneuring emphasises this phenomenon 'as a complex web of intertwined socio-economic and politically framed activities constructed by contextualised institutional frameworks' (Tedmanson et al. 2012, 533). Here community entrepreneurship epistemologically and ontologically differs from standard definitions of social entrepreneurship. Awabakal Cooperative, Yarnteen, Miromaa, Wandiyali, the Wollotuka Institute, and the Awabakal Local Aboriginal Land Council are anchored in the community. Community entrepreneurship implicitly advances Indigenous community interests. That is, community entrepreneuring activities, processes, and projects were communal social processes that have not only a social and cultural function but also a civil society function (Cho 2006, 37-39; Steyaert \& Hijorth 2007; Hjorth 2007). Entrepreneuring became a 'catalyst for social transformation' (Alvord, Brown, \& Letts 2004, 262). Community entrepreneuring advanced a sociological, 'sui generis vision of the "social" good, one irreducible to and greater than the sum total of individual welfare functions' (Thornton 1999; Cho 2006, 37). Community entrepreneuring was focused on community development (altruism, improving social conditions, rights, self-determination, and empowerment) (Rindova, Barry, \& Ketchen 2009). The political context is critical, as too is the historical and cultural context from which First Nations organisations arise. Yarnteen's vision, for example, was to become a 'full free agent in our own development' (Jonas 1991, 12).

Paul Tapsell and Christine Woods define social entrepreneurship in Indigenous contexts as follows: 'the construction and pursuit of opportunities for transformative social change through innovative activities occurring within or across economic and social communities in a historical and cultural context' (Tapsell \& Woods 2010, 149). That is, 'rather than profit or wealth creation; the social enterprise seeks to create something of value that is congruent with the social cause and the social community' (Tapsell \& Woods 2010, 149; Overall, Tapsell, \& Woods 2010). Community entrepreneuring does more than 'effect social change by altering the social, economic, political day-to-day realities at the local level' (Mair 2010,4). It is also the local context that determines the strategies and tactics employed, which 'reflect an entrepreneurial approach to action characterised first by resourcefulness (without necessarily having the resources in hand); second by the ability to recombine new value-creating configurations ('bricolage' of material, institutional, and cultural resources); and finally, by creative and innovative, that is novel ways of doing things' (Mair 2010, 4).

\section{Creating an Indigenous social economy in the city: an Indigenous ethic of care in cities}

Today, in the Australian city of Newcastle, an Indigenous care economy sits alongside an Indigenous education and training economy. It includes the Awabakal preschools, the Yarnteen College, and an Indigenous institute at the local university. These programs and initiatives have been grounded in social and 
cultural norms, supporting cultural activities, cultural maintenance, and community building. Such initiatives sit alongside language resurgence programs, Elders programs, and arts and crafts programs. Collectively, the corporations and community enterprises local Kooris have set up have created appropriate jobs for First Nations peoples in this city where there were increasingly high rates of unemployment and limited employment opportunities. Community-owned and community-based organisations have directed their attention toward addressing social problems experienced by local Kooris in constructive ways that have created economic opportunities and benefits for local Kooris.

Indigenous care ethics are practised through Indigenous institutions. Building on Tronto's concept of an ethics of care, Indigenous care is about maintaining, continuing, and repairing Indigenous lifeworlds, bodies, selves, and country/ nation and place (Tronto 1993, 113). Indigenous care ethics has developed in response to dispossession, displacement, and relocation. It involves Indigenous practices. It 'emerges from the values and expectations inherent within extended family models of care that are formed through kinship ties, obligatory practices, expectations and the roles and responsibility of care by siblings, parents and aunties and uncles' (MacGill \& Blanch 2013, 146).

It is through Indigenous ethics of care that First Nations organisations have catalysed the economic prosperity of the community. It has created economic benefits and net returns to the city of Newcastle. The community entrepreneuring that local Kooris engaged in has been directed at building an economy of care, education, and training in this city. Local Kooris created a medical service, disability service, housing services, Elders services, day care centres, and preschools. Colleges and training programs created. Indigenous centres within universities created. They created employment services that assist with placing First Nations peoples in various sectors of employment within cities. This social infrastructure sits alongside legal services, refuges, hostels, social housing, affordable housing services, language services, transport services, youth services, justice services, and child protection and out-of-home care services. While creating economic benefits and net returns, the formation of Indigenous social infrastructure has improved the quality of life of Kooris living in this city.

Like David Newhouse observes elsewhere in the context of Canadian cities, Indigenous social infrastructure has created jobs; improved educational outcomes; improved health and wellbeing; encouraged social inclusion; created sustainable communities of association; improved First Nations peoples' access to facilities, services, and programs; reinvigorated culture; and increased Indigenous social mobility (Newhouse 2003). ${ }^{1}$ Like elsewhere, it has allowed local Kooris to access specialised culturally centred, culturally safe services and programs that are well targeted to their needs as well as to mitigate experiences of racism often associated with accessing mainstream programs and services (Newhouse 2003, 13).

Koori leaders and Elders have been mindful too of the interconnections between different social problems, such as how family violence has far-reaching effects on 
homelessness among Indigenous women, children, and men. Family violence is considered a major contributor to social problems among young people living in Newcastle, affecting school attendance and resulting in out-of-home care and contact with the justice system. The complex layers of Indigenous disadvantage experienced by Kooris living in Newcastle, including discrimination and cultural alienation, would not be experienced by non-Indigenous Novocastrians. Kooris experience a constellation of disadvantage 'that is an artefact and legacy of Australia's settler-colonial history and the institutionalised structuring of Indigenous/ settler social relations in Australia over 200 years' (Howard-Wagner 2018a, 1338). Kooris leaders created an interconnected social and health service system that could provide holistic support to local First Nations peoples. Indigenous underrepresentation at the frontline in social service system mattered. It was a move away from the models of delivery employed defined and shaped by government bureaucrats and administrators within the social and health systems, including education, housing, and health services. It was a move away from conventional Western social and health service delivery and work to create a space imbued with values of community and cultural governance, collective ownership, and shared identity. The creation of Indigenous social infrastructure was a means of overcoming disadvantage as a racialised experience. Indigenous social infrastructure is the foundation that supports socio-economic improvements, including skills development and jobs and the growth of Indigenous business and entrepreneurship. The creation of Indigenous social infrastructure has been a step-by-step process. Local Kooris built strong, leading First Nations organisations and programs to meet the pressing local needs of First Nations peoples, nurturing those programs, starting with a vision and progressing toward realising it. It is these programs that have actually improved socio-economic outcomes for Kooris in this city.

The strong social fabric, community building, and place-based economy of exchange and reciprocity that had been facilitated and nurtured by collective entrepreneuring have enabled Koori leaders to mobilise as agents of social change and to build Indigenous social infrastructure in this city. Social change was as much about improving the wellbeing of the whole community as it was about cultural resurgence in this city. Culture, community, and cultural governance have been critical factors in the creation of successful First Nations organisations that have tackled Indigenous disadvantage as experienced by First Nations peoples.

\section{Indigenous practices and governance}

Our organisation plays a key role in this community because it touches on well, it impacts on the community at a range of different levels, basically from birth through to Elders and at some point, at some stage, any member of this community will have a relationship with the organisation.

(transcript Program Manager, Indigenous organisation 3) 
We engage with the community and the importance of engaging with the community is about having a joint vision with the community for cultural empowerment and self-determination.

(transcript former CEO, Indigenous organisation 2)

\begin{abstract}
A strong social or communal base drove the establishment of Aboriginal community enterprises locally. There's a really good base here and it's a social base within our own community. There are some very big, dominant, longstanding organisations that the community respond to and have very significant cultural processes.
\end{abstract}

(transcript 58)

Culture, knowledge of community, the mandate of the community, the cultural advice of Elders forefront the practice of Indigenous organisations in this city. This is reflected in the following interview extract:

Knowledge of community, Knowledge of who's in the community and understanding of our own culture first. . . . You learn from your Elders. . . . You work through the different things in your community. That's leadership. . . . As long as that culture's taken into consideration and it's respected, then your governance and leadership will follow.

(transcript 55)

First Nations organisations not only operate as an autonomous or safe 'Indigenous space'. Indigenous knowledges, systems, and practices operate as a positive, active, and empowering tool for change. Wandiyali is not a participant in the Indigenous child wellbeing and protection system; rather, it has taken control of the many dimensions of Indigenous child wellbeing to provide a holistic service for Koori children in Newcastle and regionally (Howard-Wagner 2015). It is an agent for Indigenous empowerment, social change, and self-determination. Wandiyali also operates as an autonomous or safe 'Indigenous space', which is a restricted cultural and social space in the sense that it is restricted to Aboriginal and Torres Strait Islander peoples. Wandiyali is deeply situated in and part of the local community, and it adheres to Indigenous protocols in the development of its organisational practices and programs: 'If there is anything that we need that is cultural, we do not just make decisions in here, our Elders are consulted and asked because they are the most important people in our community to us' (transcript, General Manager Wandiyali). Wandiyali's programs and services forefront the role of Elders as teachers and healers, and they are underpinned by a culture-based philosophy - incorporating Indigenous knowledges, systems, and teachings. Indigenous knowledges, systems, and practices of culture operate as a positive, active, and empowering tool for change. 
It situates the child and young persons' wellbeing and care in community using cultural resources to respond to the needs of the child and young person, connecting the child or young person to community, and replicating or reproducing some of the core cultural and kinship functions of the Indigenous community and Indigenous culture to respond to the needs of the child and young person. It nurtures the child and/or young person and assists the child and/or young person to heal.

The General Manager of Wandiyali has developed several innovative programs to achieve this vision, including its Respectful Relationships program for young people and Burri, a parenting program for young, homeless, pregnant Koori women. Historically, government funding facilitated its capacity to do so, allowing it to develop locally specific, culturally safe programs. Wandiyali's operational principles - which could not be replicated in the mainstream because they are epistemologically and ontologically different - forefront Indigenous culture and ways of doing business; the significance of First Nations peoples and Elders designing programs for their children, young people, parents and families; and community accountability, collective responsibility, and community involvement (Howard-Wagner 2015).

In the era of state recognition, Indigenous organisations became important expressions of Indigenous agency, empowerment, autonomy, and selfdetermination. Their objectives have been complementary to the business of the state, but they intend to do business their way and in accordance with the real needs of First Nations peoples at a local level.

This history is not unique to Newcastle.

\section{Note}

1 Australia Bureau of Statistics data between 1996 and 2006 demonstrate marked improvements in education and employment among local Kooris. Today, according to the Australian Bureau of Statistics Census data, to quote one local Koori, the Newcastle Indigenous population 'sits at the top of the bottom socio-economic pile' (interview 53).

\section{References}

Alvord, S, Brown, D \& Letts, C W (2004). 'Social Entrepreneurship and Societal Transformation: An Exploratory Study', The Journal of Applied Behavioural Science, Vol. 40, No. 3, pp. 260-282.

Anderson, R, Honig, B \& Peredo, A (2006). 'Communities in the Global Economy: Where Social and Indigenous Entrepreneurship Meet', in Steyaert, C \& Hijorth, D (eds.), Entrepreneurship as Social Change: A Third Movements in Entrepreneurship Book. Northampton, MA: Edward Elgar Publishing.

Arthur, B (1994). The Same but Different: Indigenous Socio-Economic Variation. Canberra: Australian Institute of Aboriginal and Torres Strait Islander Studies.

Barnes, H M (2000). 'Kaupapa Maori: Explaining the Ordinary', Pacific Health Dialog, Vol. 7, No. 1, pp. 13-16. 
Blyton, G (1995). 'First Contact', in Turner, J \& Blyton, G (eds.), The Aboriginal of Lake Macquarie: A Brief History. Lake Macquarie, NSW: Lake Macquarie City Council.

Bobiwash, A R (1997). 'The History of Native People in the Toronto Area: An Overview', in The Meeting Place: Aboriginal Life in Toronto, Toronto: Native Canadian Centre Toronto, pp. 5-24.

Cho, A H (2006). 'Politics, Values and Social Entrepreneurship: A Critical Appraisal', in Mair, J et al. (eds.), Social Entrepreneurship. London: Palgrave Macmillan.

Gagne, N (2013). Being Māori in the City: Indigenous Everyday Life in Auckland. Toronto: University of Toronto Press.

Gagne, N (2016). 'The Waxing and Waning of the Politics of Authenticity: The Situation of Urban-Based Māori Through the Lens of Municipal Politics', City \& Society, Vol. 28, No. 1, pp. 48-73.

Graham, KA (1998). 'Urban Aboriginal Governance in Canada: Paradigms and Prospects', Zeitschrift Fur Kanada Studien, Vol. 18, pp. 77-89.

Hindle, K \& Lansdowne, M (2005). 'Brave Spirits on New Paths: Toward a Globally Relevant Paradigm of Indigenous Entrepreneurship Research', Journal of Small Business and Entrepreneurship - Special Issue on Indigenous Entrepreneurship, Vol. 29, No. 1-2, pp. 1-23.

Hindle, K \& Moroz, P (2010). 'Indigenous Entrepreneurship as a Research Field: Developing a Definitional Framework from the Emerging Canon', International Entrepreneurship and Management Journal, Vol. 6, No. 4, pp. 357-385.

Hjorth, D (2007). 'Lessons from Iago: Narrating the Event of Entrepreneurship', Journal of Business Venturing, Vol. 22, No. 5, pp. 712-732.

Howard, H A (2004). Dreamcatchers in the City: An Ethnohistory of Social Action, Gender and Class in Native Community Production in Toronto. Toronto: University of Toronto.

Howard-Wagner, D (2015). 'Child Wellbeing and Protection as a Regulatory System in the Neoliberal Age: Forms of Aboriginal Agency and Resistance Engaged to Confront the Challenges for Aboriginal People and Community-Based Aboriginal Organisations', Australian Indigenous Law Review, Vol. 19, No. 1, pp. 88-102.

Howard-Wagner, D (2017). 'Successful Urban Aboriginal-Driven Community Development: A Place-Based Study of Newcastle', CAEPR Discussion Paper.

Howard-Wagner, D (2018). 'Governance of Indigenous Policy in the Neo-Liberal Age: Indigenous Disadvantage and the Intersecting of Paternalism and Neo-Liberalism as a Racial Project', Ethnic and Racial Studies, Vol. 41, pp. 1132-1151.

Jonas, W (1991). Awabakal, Bahtabah, Biripi, Worimi: Four Successful Aboriginal Organisations. Newcastle: University of Newcastle.

Langford, W (2016). 'Friendship Centres in Canada, 1959-1977', American Indian Quarterly, Vol. 40, No. 1, pp. 1-37.

La Pier, R \& Beck, D (2015). City Indian: Native American Activism in Chicago, 18931934. Lincoln and London: University of Nebraska Press.

Levine, H B (2001). 'Can a Voluntary Organisation Be a Treaty Partner? The Case of the Whanau O Waipareira Trust', Social Policy Journal of New Zealand, Vol. 17, pp. 161-170.

Lindsay, W G (1998). A History of the Vancouver Aboriginal Friendship Centre in an Age of Aboriginal Migration and Urbanization. Vancouver: UBC Press.

Lobo, S (2002). Urban Voices: The Bay Area American Indian Community. Arizona: University of Arizona Press. 
Macgill, B M \& Blanch, F (2013). 'Indigenous Students' Wellbeing and the Mobilisation of Ethics of Care in the Contact Zone', Australian Journal of Teacher Education, Vol. 38, No. 2, p. 10.

Mair, J (2010). 'Social Entrepreneurship: Taking Stock and Looking Ahead', IESE Business School Working Paper No. WP-888.

Martinez, D (2016). 'Building an Urban Rez: American Indian Intertribal Organizations in the Twentieth Century', in Martinez, D, Sage, G \& Ono, A (eds.), Urban American Indians: Reclaiming Native Space, pp. 63-84.

Maynard, J (2001). 'Muloobinbah (Newcastle) an Aboriginal Industrial Presence: Past and Present', Journal of Royal Australian Historical Society, Vol. 87, No. 2, pp. 248-266.

Native Canadian Centre of Toronto (2020). 'About Us, Native Canadian Centre', https:// ncct.on.ca/about-us/, accessed 10 July 2020.

Newhouse, D R (2003). 'The Invisible Infrastructure: Urban Aboriginal Institutions and Organizations', in Newhouse, D \& Peters, E (eds.), Not Strangers in These Parts: Urban Aboriginal Peoples. Ottawa: Policy Research Initiative, pp. 243-253.

NSW Ombudsman (2011). 'Addressing Aboriginal Disadvantage: The Need to Do Things Differently', A Special Report to Parliament Under s 31 of the Ombudsman Act 1974, October 2011. http://alc.org.au/media/73895/sr_aboriginal\%20disadvantage $\% 20$ report\%20oct11.pdf.

Obonsawin, R \& Howard-Bobiwash, H (1997). 'The Native Canadian Centre of Toronto: The Meeting Place for Aboriginal People for 35 Years', in The Meeting Place: Aboriginal Life in Toronto. Toronto: Native Canadian Centre of Toronto, pp. 25-59.

Overall, J, Tapsell, P \& Woods, C R (2010). 'Governance and Indigenous Social Entrepreneurship: When Context Counts', Social Enterprise Journal, Vol. 6, No. 2, pp. 146-161.

Pearson, C A \& Helms, K (2013). 'Indigenous Social Entrepreneurship: The Gumatj Clan Enterprise in East Arnhem Land', Journal of Entrepreneurship, Vol. 22, No. 1, pp. 43-70.

Peredo, A M \& Chrisman, J J (2010). 'Toward a Theory of Community-Based Enterprise', The Academy of Management Review, Vol. 31, No. 2, pp. 309-328.

Puketapu-Dentice, K, Connelly, S \& Thompson-Fawcett, M (2017). 'Towards Integrating Indigenous Culture in Urban Form', Justice Spatiale Spatiale Justice, Vol. 11, pp. 2-19.

Purdue, D (2001). 'Neighbourhood Governance: Leadership, Trust and Social Capital', Urban Studies, Vol. 38, No. 12, pp. 2211-2224.

Putnam, R D \& Feldstein, L M (2003). Better Together: Restoring the American Community. New York: Simon \& Schuster.

Reynolds, L (2015). Transformative Planning Practice and Urban Indigenous Governance in Vancouver, British Columbia. Vancouver: Simon Fraser University.

Rindova, V, Barry, D \& Ketchen, D (2009). 'Entrepreneuring as Emancipation', The Academy of Management Review, Vol. 34, No. 3, pp. 477-491.

Rosenblatt, D (2002). 'Titirangi Is the Mountain: Representing Maori Community in Auckland', Pacific Studies, Vol. 25, No. 1, pp. 117-140.

Rowse, T (2012). Rethinking Social Justice: From 'Peoples' to 'Populations'. Canberra: Aboriginal Studies Press.

Ryks, J, Howden-Chapman, P, Robson, B, Stuart, K \& Waa, A (2014). 'Maori Participation in Urban Development: Challenges and Opportunities for First Nations Peoples in Aotearoa New Zealand', Lincoln Planning Review, Vol. 6, No. 1-2, pp. 4-17. 
Smith, D (2005). 'Indigenous Households and Community Governance', in Austin-Broos, D \& Macdonald, G (eds.), Culture, economy and governance in Aboriginal Australia. Sydney: Sydney University Press.

Smith, D (2008). 'The Business of Governing: Institutional Capital in an Urban Enterprise', in Hunt, J, Smith, D, Garling, S \& Sanders, W (eds.), Contested Governance: Culture Power and Institutions in Indigenous Australia. Canberra: CAEPR Monograph, ANU Press.

Steyaert, C \& Hijorth, D (2007). Entrepreneurship as Social Change: A Third Movements in Entrepreneurship Book. Northampton, MA: Edward Elgar Publishing.

Tamihere, C (2015). "Kōkiritia i roto i te kotahitanga": A Process Evaluation of a Wraparound Programme at Te Whānau o Waipareira Trust. Doctoral Dissertation, ResearchSpace@Auckland.

Tapsell, P \&Woods, C R (2010). 'Social Entrepreneurship and Innovation: SelfOrganization in an Indigenous Context', Entrepreneurship \& Regional Development, Vol. 22, pp. 535-556.

Tedmanson, D et al. (2012). 'Critical Perspective in Entrepreneurship Research', Organization, Vol. 19, No. 4, pp. 531-541.

Thornton, P H (1999). 'The Sociology of Entrepreneurship', Annual Review of Sociology, Vol. 25, No. 1, pp. 19-46.

Tronto, J (1993). 'A Political Argument for an Ethic of Care', in Moral Boundaries. New York: Routledge.

Yarnteen (2020). www.yarnteen.com.au/.

Yarnteen Annual Report (2019). www.acnc.gov.au/charity/128f0a1aa368368d87b6cc871 7 eedb19. 


\section{A 'renewed right to urban life' Reconciliation and Indigenous political agency}

Ray Kelly of the Awabakal Aboriginal Cooperative, Michael Eckford originally of Brewarrina, Jeff Bradford of Worimi Local Aboriginal Land Council and Bill Smith of Kumpahtoo Local Aboriginal Land Council were among those who urged us to stand alongside Kooris and work for a local treaty, not necessarily a legal document, but a moral commitment that could find support at a local government level. ...

Signatories to the Commitment were invited to take part in the Coming Together ceremony on Newcastle Foreshore an especially significant site: in the story of the Awabakal people a giant black kangaroo jumped from the headland of Fort Scratchley to Nobby's across to Stockton. It is also significant as a place where the Awabakal people first encountered the colonisers. ...

[At] Horseshoe Beach ... [w] waited. Every so often when another friend arrived and greeted me, the media asked if this was the messenger. I could only tell them that Ray Kelly had told me ... "You will know"... . Suddenly the messenger was unmistakably there, body paint, loincloth motioning us with a fan of eucalyptus leaves for about twenty metres, only to be signalled to sit down again. As we came closer to the amphitheater, we caught sight of a huge crowd, the other group of supporters some distance away towards the Customs House. . .

We walked in a snake formation and passed through eucalyptus smoke as a purifying before shaking hands with the Aboriginal Elders. . . . None of us had dreamt of that day some two thousand non-Aboriginal people would pass through the smoke and join the celebrations together with about five hundred Aboriginal and Torres Strait Islander people.

(Farrell \& Meehan 1997, 345-347)

Twenty years after Kooris leaders had gathered for the signing of a local document of reconciliation and Coming Together Day in the city of Newcastle, Elders gathered in the city of Vancouver to discuss reconciliation. Coming Together Day, described here, marked the signing of the first local document of reconciliation in Australia. Over 2,000 non-Indigenous and 500 First Nations peoples attended. 
The account briefly describes the process leading to the development of the Commitment to Indigenous Australians. The Commitment marked the United Nations Year of the World's Indigenous Peoples.

Over two days in November 2012, First Nations Elders had gathered for an Elders Circle on traditional Musqeuam Nation to discuss reconciliation in the city of Vancouver (Reconciliation Canada 2013a). The Elders called on 'all Canadians to become engaged in reconciliation to validate the experience of First Nations peoples and to embrace the notion that we can vision a future together as a society' (Chief Dr Robert Joseph 2012, quoted in Reconciliation Canada 2013). Six months later, a Reconciliation Dialogue Workshop was held on 1 May 2013 at the Musqueam Cultural Centre (Reconciliation Canada 2013b). Participants engaged in Indigenous practices of dialogue and storytelling, and among the participants were the Chief Dr Robert Joseph of the Gwawaenuk First Nation and Vancouver Mayor Gregor Robertson (Reconciliation Canada 2013b). Chief Joseph declared that:

This is a pivotal moment in time and an opportunity for all the peoples of Canada to come together to build new relationships that are supported on a foundation of openness, dignity, understanding and hope. We are taking the diversity dialogue to a new level - engaging our youth with a positive message that inspires a hopeful outlook in their everyday life.

(Reconciliation Canada 2013b)

On the eve of National First Nations Peoples Day, the then Mayor of Vancouver proclaimed 21 June 2013 to 20 June 2014 a year of reconciliation. The then Mayor declared that: 'Vancouver's Year of Reconciliation is about building a common future together - one that acknowledges the historic impacts that have shaped the experiences of Aboriginal peoples across Canada' (Bergen 2013, 1). A growing social movement and a groundswell of events led up to a week of reconciliation in September 2013, which would include the All Nations Canoe Gathering at False Creek and the Walk for Reconciliation.

Twenty years earlier, the same agents of Indigenous community development in Newcastle had mobilised the federal reconciliation agenda to assert an Indigenous right to the city. It was the Chief Executive Officers of First Nation organisations in the region, like Ray Kelly (then Chair of the Awabakal Cooperative), Bill Smith (Chair of Koompahtoo Local Aboriginal Land Council in the Lake Macquarie region), and Jeff Bradford (Chair of the Worimi Local Aboriginal Land Council), who drafted the first local document of reconciliation in Australia. Reconciliation began with a vision of a treaty for the greater Hunter Region, which included the cities of Newcastle, Lake Macquarie, and Maitland, as well as the area of Port Stephens and Hunter Valley. The international focus of the United Nations Year of the World's Indigenous peoples was on Indigenous/state relations with the theme being 'Indigenous peoples - New Partnerships'. Over 3,000 nonIndigenous peoples and the local government signed the document in October and 
November 1993. Coming Together Day marked the signing of the document. The earlier account is an extract from a chapter authored by local activist Moira Farrell and local Koori woman Donna Meehan about Coming Together Day in 1993.

Coming Together Day formed part of the annual Mattara festival. The Mattara Festival first commenced in 1961. It is most aptly described as a festival of origins. The name Mattara is Awabakal for hand, and, in this context, denotes the hand of friendship. In 1993, Coming Together Day formed part of weeklong events for the Mattara Festival. Coming Together Day not only functioned as a heterotopic social space and performative politics, reflecting Indigenous protocols, but also as a performative dialogue with non-Indigenous Novocastrians (Henry 2008, 53). Indigenous protocols illustrated how the production of public spaces could be decolonised. The enactment of Indigenous protocols also operated to challenge, contest, invert, and reverse conventional and received understandings of social spaces of whiteness and social relations between First Nations peoples and nonIndigenous Novocastrians traditionally constituted within those spaces (Danaher, Moriarty, \& Danaher 2006). It was a reclaiming and reimagining of the social space and social relations, and it was an opportunity for non-Indigenous members of the community to bear witness to First Nations peoples' visions for an alternative future.

Coming Together Day was a turning point in the struggle for an Indigenous right to the city of Newcastle. Kooris mobilised reconciliation to change their relationship with non-Indigenous Novocastrians. Two years earlier, the Australian federal government had established a Council for Aboriginal Reconciliation in 1991. Reconciliation was a recommendation of the Royal Commission into Aboriginal Deaths in Custody (Johnston 1991). From 1993 to 2001, reconciliation became a people's movement in Newcastle. In 2000, it culminated in a Hunter Peoples' Inquiry into a Treaty. The Inquiry recognised the right of Indigenous communities to control their own affairs and called for the establishment of an elected Indigenous community council to control government funds allocated to organisations and services (Extract from the Hunter Peoples' Inquiry into a Treaty 2000, Newcastle Aboriginal Support Group 2001, 13-14). Reconciliation became a means to intervene in systemic processes that had marginalised Indigeneity in the city and to strengthen the position of First Nations Peoples.

Before I left Australia for Vancouver, I attended the launch of Newcastle City Council's Reconciliation Action Plan (RAP) at Newcastle's City Hall on Monday, 3 June 2013. Reconciliation Action Plans had become a strategic document to support an organisation's business plan in relation to reconciliation, outlining practical actions that determine an organisation's contribution to Closing the Gap.

The moment marked the fragility of hopeful spaces. The launch of the Newcastle City Council Reconciliation Action Plan was a stark contrast to Coming Together Day. It took place in Newcastle Town Hall in 2013. It opened with a Welcome to Country performed by a local Awabakal Elder. The RAP was then 
officially launched by the then Chair of Reconciliation Australia, Leah Armstrong a Torres Strait Islander woman who has lived in Newcastle since the 1980s. Armstrong had first worked at the Awabakal Cooperative, then she became the CEO of Yarnteen and later went on to become the Chair of Reconciliation Australia. Aside from the presence of Armstrong, the then CEO of the Awabakal Local Aboriginal Land Council, a local Elder and two Koori staff then employed by Newcastle City Council, those present were mostly Newcastle City Council staff and officials. The moment rendered invisible the historical aspirations for reconciliation in Newcastle - that is, Indigenous aspirations for recognition, a right to the city, and a treaty.

Having started with Closing the Gap, 20 years later the City of Vancouver was turning to reconciliation. In June and July 2013, while in Vancouver comparing Indigenous relocation and community development in the two cities, I observed that governments had already been partnering with community-based First Nations organisations in Closing the Gap in Vancouver. In the early 1990s, communitybased First Nations organisations in Vancouver had supported a strategy to address the long-term systemic challenges faced by First Nations peoples living in this city through a Metro Vancouver Aboriginal Strategy. It was part of Canada's Urban Aboriginal Strategy. The objective of the Metro Vancouver Aboriginal Strategy was to renew the relationship between governments and Indigenous peoples through an urban Aboriginal strategy focused on service delivery. Community-based First Nations organisations had committed to working more closely together with governments in a coordinated approach to close gaps and better advance the needs of the communities they serve. Over time, the Metro Vancouver Aboriginal Strategy had become increasingly neoliberal in its governance of First Nations organisations (Bellerose 2017, 5). Government departments controlled First Nations organisations through forms of funding accountability and targeted programs 'highly specified' by government (Bellerose 2017, 6). Increasingly community-based First Nations organisations were referred to as Indigenous service delivery organisations. Mutual responsibility had replaced self-determination.

The observations revealed how cities fail to grapple with the complexities and meaning of reconciliation, particularly in the context of recognition, relationship building, and overcoming Indigenous disadvantage. The complexity of Indigenous identities, practices, and agendas had become invisible in Vancouver. The great pride in First Nations/Métis/Inuk and their collective Aboriginal identities in Vancouver and the very strong sense of cultural vitality, self-determination, community building, and development were hidden in plain sight. Communitybased First Nations organisations and their communities had become invisible. Community-based First Nations organisations were now only seen as Indigenous service organisations. The communities they served were merely seen by the city and the state as urban Aboriginal people who experienced disadvantage.

By way of further illustration, Vancouver is undergoing significant urban renewal and touts itself as a leader in reconciliation. At the same time, it is 
marginalising and displacing First Nations peoples through its management of the housing and social service crisis in the city. In March 2019, the city counted 2,223 homeless people in its annual homelessness count with Indigenous people making up 39 per cent, and possibly higher, despite only accounting for 2 per cent of Vancouver's overall population (Howell 2019). Indigenous homelessness is concentrated in the downtown Eastside of Vancouver. This is also the location of many of the community-based First Nations organisations that have been established in the city, including the Vancouver Aboriginal Friendship Centre, Aboriginal Front Door Society, Vancouver Aboriginal Health Service, Vancouver Native Housing Society, Urban Native Youth Association, and Vancouver Aboriginal Policing Centre Society. The stark reality of this confronts you if you go to Oppenheimer Park or East Hastings Street in Downtown Eastside Vancouver, as homeless camps have popped up in the park and down alleys, and almost half of those camping in tents are First Nations people. On 20 July 2014, Vancouver issued an eviction notice to homeless First Nations peoples living in Oppenheimer Park in Downtown Eastside Vancouver, which is not only on Musqueam Territory but the heart of inter-nation community building and development over the last 60 years. The issuing of 24-hour eviction notices to homeless First Nations peoples evoked outrage by the Musqueam, Tseil-Waututh, and Squamish Traditional owners in the Vancouver region, who stepped forward to challenge the city's right to issue the eviction orders. The Musqueam, TseilWaututh, and Squamish Traditional owners issued an eviction notice of their own on the city. First Nations protestors moved in and erected a camp alongside the homeless camp.

The city has since built temporary modular housing with studio apartments in the outer areas of the inner city, relocating those who are homeless to the temporary modular dwellings away from East Hastings Street and Downtown Eastside Vancouver. It evicted and relocated those living in the tent city in Oppenheimer Park on 21 August 2019. First Nations tenants now occupy 40 per cent of Vancouver's new temporary modular housing and now live a 30- to 40-minute public transport ride away from Indigenous social infrastructure in East Hastings Street.

While reconciliation has been mobilised by First Nations peoples as a means for actualising a right to the city, there are deeply ingrained disconnects between Indigenous standpoints about what reconciliation is compared to the perspectives of those governing cities. Chapter 5 reflects on how local Kooris attempted to mobilise reconciliation as a political means for asserting an Indigenous right to the city of Newcastle. It is not my aim to analyse to what extent reconciliation adheres to an ideal type of participation or recognition, or to define reconciliation, but to describe reconciliation in practice - that is, how it was mobilised as a means of enacting an Indigenous right to the city. The chapter continues to examine how Indigenous resurgence in the city of Newcastle was a practical, grounded mode of being and resistance (Simpson 2011, 17; Elliott 2018, 64). Resurgence is directed toward positive alternative social realities and entails direct discursive engagement with settler society (Elliott 2018, 61). Local Kooris were not turning 
away from the institutions of the state or disengaging with the state order (Alfred 2009a, 2009b, 2013; Alfred \& Corntassel 2005; Corntassel 2012; Coulthard 2014; Simpson 2011, 2014; Coulthard \& Simpson 2016).

The complexities of transforming Indigenous/settler relations in settler-colonial cities are discussed in Chapter 6, which follows. I provide a more detailed analysis of the effects of rendering community-organisations as service delivery organisations on Indigenous agendas, practices, and governance in Chapter 7, focusing on this neoliberal way of seeing as it has played out more recently in Newcastle.

\section{Eight years of reconciliation: from coming together to the Currawong Project}

In June 2013, the then Mayor of Vancouver Gregor Robertson had made a statement committing his local government and the City of Vancouver to reconciliation in the presence of 'Squamish, Musqueam and Tsleil-Waututh First Nations, as well as Reconciliation Canada, the First Nations Leadership Council and the Metro Vancouver Aboriginal Executive Council' (Bergen 2013, 1). The then Mayor stated that:

It's important that all Vancouver residents build our understanding of the histories, contributions, and persistent challenges faced by Aboriginal people in Canada, and that City Hall continues to strengthen relationships and dialogue with the Musqueam, Squamish, and Tseil-Waututh Nations.... The Year of Reconciliation in Vancouver will provide an opportunity for people of all cultures to engage in dialogue and work together for a shared future that fully supports the rights and aspirations of Aboriginal people living in and around Vancouver.

The then Mayor Robertson proclaimed on 23 February 2013 that 21 June 2013 to 20 June 2014 would be a Year of Reconciliation, following a unanimous motion from the Urban Aboriginal Peoples' Advisory Committee (UAPAC) that passed on 23 January 2013. The UAPAC unanimously carried a motion to recommend to Vancouver City Council that (1) a Year of Reconciliation occur, (2) Vancouver be named the City of Reconciliation, (3) 'the City of Vancouver recognise the United Nations Declaration of Indigenous Right in light of Idle no More and Reconciliation Canada', and (4) Council support teach-ins throughout the City of Vancouver regarding the rights of First Nations peoples to bridge the gaps between First Nations and other Canadians. The UAPAC also recommended that teach-ins should include the Canadian government changes to bills C45 and C38, and any other changes that affect Aboriginal people.

In 2014, the City of Vancouver also appointed a Manager of Aboriginal Relations in the city, whose 'job it is to ensure policies, practices and decisions incorporate the understanding of whose land the city rests upon and what needs to be done to address the wishes and concerns of the local First Nations governments'(Canadian Broadcasting Commission 2016). In 2017, Aboriginal people in Vancouver 
celebrated $150+$ years of colonisation with the theme of 'Strengthening Our Relations'. Its point was to acknowledge the colonisation but also to 'affirm Aboriginal peoples' place in the city' (Gosnell-Myers, cited in Canadian Broadcasting Commission 2016). The year-long Strengthening Our Relations project is 'one of the responses to the Truth and Reconciliation Commission's Calls to Action: to use Canada's 150th anniversary as a time for Indigenous recognition and celebration with all Vancouverites' (Canadian Broadcasting Commission 2016).

The words of the then Vancouver Mayor on 21 June 2013 reminded me of the words used by local white author and activist Paul Walsh and Dhunghutti playwright and local Koori activist Ray Kelly Senior 13 years earlier to represent reconciliation in Newcastle through a local initiative known as the Currawong Project in 2000. At the time, Kelly was also the General Manager of the Awabakal Cooperative and Aboriginal and Torres Strait Islander Commission (ATSIC) Regional Councillor. The 2001 Currawong Project was launched on Australia Day, 2001 in Newcastle's King Edward Park. The year was symbolic in several ways in that it was the Australian Centenary of Federation and the final year in the ten-year lifespan of the Council for Aboriginal Reconciliation. The Council for Aboriginal Reconciliation had been established by the Commonwealth Parliament as a statutory body under the Council for Aboriginal Reconciliation Act 1991. The Council's role had been to promote a process of reconciliation between Aboriginal and Torres Strait Islander peoples and the wider Australian community.

In Newcastle, Coming Together Day had marked the beginning of a decade of federally legislated reconciliation in Australia, and the Currawong Project marked the end of that formal decade (1991-2001). The theme for the Currawong Project was 'Planting a Shared Future Together'. The Currawong Project formed part of a broader vision for Kelly and Walsh to find ways to symbolically and practically mark the 'reconciliation of blacks and whites'. As Walsh stated: 'The currawong was chosen as a symbol because of its "double call in the bush: it's a double call to black and white" '(Kirkwood 2001, 8). The Currawong Project involved a series of events that took place throughout 2001, commencing with the building of Uncle Bob's Yallarwah Place at the John Hunter Hospital. This proceeded a Year of Reconciliation initiative that began with the launch of the project in King Edward Park. A couple of months later, the public was invited to Uncle Bob's Yallarwah Place at the John Hunter Hospital to plant native seedlings in the bushland around Yallarwah Place to commemorate both the Australian Centenary of Federation and the final year of the Council for Aboriginal Reconciliation. Over the next 11 months, various dignitaries would plant one of the seedlings at the Circle of Reflection behind Yallarwah Place, which had grown from the seeds sewn earlier in the year. Later in the year, there was the launch of a photographic exhibition titled 'Black Feather/White Feather'.

The building of Uncle Bob's Yallarwah Place was an act of convivial reconciliation between Indigenous and non-Indigenous Australians (Bell 2016). In this case, though, Yallarwah was built by Indigenous and non-Indigenous prison detainees. 
Uncle Bob's Yallarwah Place was also the first facility of its kind. Yallarwah Place is an Indigenous accommodation centre on the grounds of the John Hunter Hospital, which is a major regional hospital. Yallarwah Place has been designed to accommodate First Nations families coming from outside of Newcastle to be with a family member who is receiving medical care at the hospital. It was another significant contribution of the Smith brothers to not only the local Koori community but First Nations peoples living in the Hunter and Northern New South Wales.

Bob's great love was certainly the Aboriginal hostel based at John Hunter Hospital. He encouraged people from his community who had broken the law and were in custody to work on the hostel and give it a proper Aboriginal accent. We recently walked around the hostel thinking of Bob. The trees that have been planted in the grounds of the hospital are living testimony to Bob's tenacity. Aboriginal ceremonial stones have also been placed below the hospital. Bob was extremely concerned about Aboriginal health generally and established the Awabakal Aboriginal Medical Centre in the Newcastle area, with which he was involved until his retirement.

(Jack Face, NSW Hansard 24 October 2001 - item 45 of 52) ${ }^{1}$

At the opening of Uncle Bob's Yallarwah Place, on our arrival, guests were invited to pass through the smoke of the Yallarwah campfire as a ritual of purification and unity. The Smoking Ceremony was performed by the respected Aboriginal Elder Uncle Bill Smith, Bob's brother.

Behind Yallarwah Place there is Yallarwah Bicentennial Walk, which weaves down through the valley (like a Rainbow Serpent) into the bushland. The Rainbow Serpent has been appropriated as a symbol of reconciliation because it is depicted in Dreaming Stories across Australia. As Paul Walsh noted in an interview: 'While the Rainbow Serpent is not part of Awabakal dreaming, Ray and I made a conscious decision to put the Rainbow Serpent in at Yallarwah Place ... because Yallarwah Place is a place for all the tribes of Northern NSW. It was a symbol of reconciliation between the tribes as well' (Walsh 2003 cited in Howard-Wagner 2006).

Making the walk (down the path shaped in the form of the Rainbow Serpent) symbolises rowing the Coquun (Hunter) River (Stace 1999). Participants in official processions that take the walk down the path to the Rainbow Serpent's head enter an imaginary canoe containing various dignitaries who are paddled down the river. At the end of the walk, at the Rainbow Serpent's head, is the 'Yallarwah Circle of Reflection'. Six large rocks mark the circle, which is said to be indicative of the Awabakal stone circle. In the centre is another large rock. This seventh rock has a memorial bronze book placed on its flat surface, which reads: 'Yallarwah Circle of Reflection. In memory of the Aboriginal people, European settlers and convicts who lived and died in our shared Hunter History 1797-1997'. The shared history is not about the recognition of Indigenous dispossession but is about recognising the shared Hunter history of First Nations peoples, European settlers, and convicts. 
At the opening, Walsh publicly stated: '[Yallarwah] is regarded as the first united memorial in Australia built by black and white people working together'. ${ }^{2}$ Kelly and Walsh spoke of past difficulties encountered in accommodating the Koori families of loved ones in the hospital. They acknowledge that a purpose-built accommodation had been an essential aspiration of Uncle Bob's for 15 years. Uncle Bob told those attending the opening ceremony of how he once asked the government for a 'house and a bus', and they refused. Yallarwah was built from funds raised from the sale of Novocastrian Tales, a book written by Paul Walsh (that was funded under the Newcastle-Hunter Bicentenary 1797-1997 program), along with funds from the State Government of NSW and corporate and community benefactors. The facility utilised Awabakal design elements in its construction. Yallarwah Place is shaped in the form of an Eagle Hawk in commemoration of Birabahn (meaning Eagle Hawk), a well-known Awabakal man who tutored the first missionary Reverend Threlkeld. The building of new architecture in the form of Yallarwah Place illustrated ways that modern forms and landscapes could be decolonised, respecting the Awabakal nation on which they were built.

Over 11 months in 2001, as part of the Currawong Project, various dignitaries were invited to officially plant a tree for reconciliation near Yallarwah Circle of Reflection. During this time, the former Governor-General (Sir William Deane), the then Governor of NSW (the Hon Marie Bashir), the former Premier of NSW (Bob Carr MP), and the then federal Shadow (Opposition) Minister for Aboriginal and Torres Strait Islander Affairs (the Hon Bob McMullan MP) were among the dignitaries that planted a tree for reconciliation.

Coming Together Day, the drafting of the Hunter Peoples' Commitment to Indigenous Australians, and the Currawong Project were a 'genuinely selfdetermining practice of resurgence and transformative form of reconciliation' (Borrows \& Tully 2018, 9). The Currawong Project and Coming Together Day rendered First Nations peoples visible in the city and created the possibilities of everyday decolonisation (Gilroy 2004; Back 2009; Bell 2016). Coming Together Day and the Currawong Project were 'teachable moments' (Corntassel 2012, 98) that operated to counter the forces of colonial and racial domination (Bell 2016, 1182). Coming Together Day was a public Corroboree that served as a public performance of resurgence, illustrating the inherent social transformations required of reconciliation. The social space illustrated a reconciled societal form (Trimikliniotis 2012, 254). It is what Foucault describes elsewhere as a productive 'counter-conduct' (Foucault 2007). It disrupted the dominance of whiteness and dominant power relations and practices that generally transpired when local Kooris engaged with local government and the broader non-Indigenous community about Indigenous issues. Indigenous practices and protocols dominated the public space, illustrating an ethical code of conduct and set of expectations, which inculcated ways of being and creating opportunities for non-Indigenous Novocastrians to learn how to do business with local Kooris (Elliott 2018, 71). Non-Indigenous Novocastrians 
were shown 'a new path and offered the chance to join in a new relationship' (Alfred 2009a, 35). Politicians, bureaucrats, and the non-Indigenous Novocastrians were actively engaged in the process of convivial decolonisation between Indigenous and non-Indigenous Novocastrians and bringing about social change.

\section{A right to the city ${ }^{3}$}

The concept of reconciliation in Australia and Canada has often been associated with addressing the historical injustices perpetrated against First Nations peoples. ${ }^{4}$ It is invoked in discussions about the relationship between First Nations and nonFirst Nations peoples in both countries. Nonetheless, reconciliation had a limited mandate in Canada in relation to the removal of Aboriginal children from their families and their involuntary placement in residential schools between 1870 and 1996 (Bergen 2013). One of the key Year of Reconciliation events in Vancouver was its hosting of the sixth of seven National Truth and Reconciliation Commission Events for Aboriginal Residential School survivors. The event included hearings and testimonies from Aboriginal Residential School survivors and their family members.

In the Australian context, reconciliation at the outset was 'a policy instrument for addressing white European possession and Aboriginal dispossession in contemporary Australia' (Wadham 2004, 192). In 1992, then Australian Prime Minister Paul Keating's now-famous Redfern speech captured harsh truths about Australia's settler-colonial history. He acknowledged the embittered damage in Australia's relationship with its First Nations peoples. ${ }^{5}$ Keating was concerned with relationship building. His speech was used as a basis for building trust with First Nations people, and it marked a turning-point for non-Indigenous understandings about reconciliation's place in changing this relationship (Clark 2013). White Australians generally recognised the significance and importance of establishing a new relationship with First Nations peoples and meaningful reconciliation. In 1993, 20 years before Vancouver, local Kooris had enacted transformative reconciliation from below. They had not turned to the transitional practices of courts and commissions, but the transformative practices of communities and social relations. Kooris shifted the focus of reconciliation to the social and political and from the state and solely government institutions to the community and the local as well as the everyday. It was a bottom-up agenda of relationship building that would envisage transformations in the social and political status of Kooris in this city.

While Coming Together Day played an essential role in making visible an Indigenous presence in the city, one of the critical objectives of reconciliation was to reinstate a visible, marked Awabakal presence in the city. A right to the city was about reasserting Indigenous authority over land and territory in the city (Rose-Redwood 2016, 187). A right to the city had been exercised with the establishment of organisations, social infrastructure, and community development. A right to the city had been established through land claims. Now a 
right to the city was to be established through a treaty, a place for Indigenous governance in matters relating to the city, and recognition of Awabakal placeidentities in everyday spaces. The practical goal of a reconciliation agenda was the regeneration of Awabakal language, the recognition of Awabakal sites, place names, and Stories.

The same movement that had established much-needed community economic, social, and cultural infrastructure now used reconciliation for decolonising the relationship between Kooris and the city. Koori leaders were looking to the future. The commitment reflected a transformative ethos. It made a claim on society and the city as the reproducer of social relations of power. The claim was for the right to participate in the political, social, cultural, and economic oeuvre of the city. Koori leaders were asking the local government and non-Indigenous Novocastrians to commit to changing the realities of this racist society (Feagin 2014, 268). They wanted respect. Koori leaders were also attempting to unsettle the social, cultural, and political dominance of settler-colonial whiteness in this city. They wanted to restore Awabakal history, culture, and language. In making these claims, local Kooris were exercising not only their urban citizenship rights through democratic practice, or their individual rights to an education, job, and housing, but exercising their unique rights as First Nations peoples to participate. That is, a right to the city went beyond the right to equal access to housing, employment, transportation, infrastructure, and government services. The right to the city was a distinctive and consciously adopted position defined by Koori leaders in the public realm. They mobilised the obligations and responsibility of local government to do so.

The right to the city is more than a claim for access to urban life, property, space, and place. The right to the city is also a struggle to 'de-alienate' urban space, to reintegrate it into the web of Indigenous social connections; and in this regard, dealienation is about re-appropriation (Lefebvre, 1943, 1996, 174; Purcell 2014, 149). It concerns, for example, the ways that urban Indigenous inhabitants re-appropriate space in the city, remaking it their own (Lefebvre 1943, 1996, 174; Purcell 2014, 149). It concerns the indispensable element of Lefebvre's right to the city, participation (Purcell 2014, 150), but the claim went beyond autogestion or self-management and the taking control of one's own existence in the form of recognition of Indigenous governance and communities in the city (Purcell 2014, 150) to inclusion and participation in the oeuvre of the city as First Nations peoples.

There is a long list of Indigenous and non-Indigenous scholars who have demonstrated how further problems arise from attempts to invert settler-colonial power within the precepts of liberalism during the recognition era (Kowal 2008, 341; Howard-Wagner \& Kelly 2011; Rowse 2012, 76; Howard-Wagner 2006, 2012; Smith 2012; Coulthard 2014; Coulthard \& Simpson 2016; Simpson 2016). The idea that liberal pluralism leads to forms of adjudicated recognition is taken up in the work of Iris Marion Young, particularly in the context of self-determination (Young 1990). Isabella Altamirano-Jimenez (2004), Paul Nadasdy (2005), Taiaike Alfred and Jeff Corntassel (2005), Colin Samson and Damien Short (2006), and 
Glen Coulthard (2007) point to the deficiency of liberalism and the politics of recognition, which they all argue have failed First Nations peoples. Colin Samson talks about the wilful ignorance of settler states and how this wilful ignorance is perpetuated through the framework of liberal pluralism. Indigenous scholars point to direct damage or harm that liberalism causes (Turner 2006), including the further acts of injustice, alienation, and violence that have been created by states through white liberal models of recognition (Turner 2006; Coulthard 2007). The effects of liberal acts of recognition are captured well in Dale Turner's reference to 'White Paper Liberalism' in his book This Is Not A Peace Pipe (Turner 2006). Recognition becomes symptomatic of what Farmer refers to as the 'deeper pathologies of power' or structural violence (Farmer 2004, 21).

Julie Tomiak considers the politics of recognition in the context of the city, arguing that it is important to interrogate and understand the relationship between cities, the state, and First Nations peoples (Tomiak 2016, 8). Tomiak problematises the settler city as a socio-spatial technology of colonialism, which operates through a range of interrelated strategies of erasure but also highlights Indigenous struggles for self-determination that include asserting the right to (be in) the city (Tomiak 2016). This concerns how cities are:

not only on deeply contested ground, but also the terrain of persistent anticolonial Indigenous struggles for life, land, and self-determination, which include struggles over the meanings and definitions of territory, place, scale, identities, and modes of governance. This is multi-scalar in that this struggle is in relation to the city itself and a politics of recognition and a right to the city, but at the same time the city is also a site of struggle that can be regional, national and international.

(Tomiak 2016, 8)

Reconciliation has proved to be yet another example of the problems that arise from attempts to invert settler-colonial power within the precepts of liberalism during the recognition era.

\section{Why reconciliation failed: white tokenistic gesturing}

I think local governments have been really progressive in terms of efforts toward reconciliation. In my experience, that's been going on for - until 1997 - quite some time. Mid-nineties, even to now, most local governments have got reconciliation action plans. They tend to all have Aboriginal employment strategies. They typically have acknowledgement to traditional owners. There's acknowledgement to country. I think local government has done a good job of bringing back a little bit of that respect.

Sometimes it flies in the face a bit, I think because it's - it comes off a little bit and smacks a little bit of being a little bit too tokenistic, I guess because 
it's like they're attempting to do a - they're trying a little bit too hard but I think local government has made progress on that issue but I - I think Newcastle's got a long way to go. I think, in terms of its view towards Aboriginal people, I think there's still some very old - yeah, I think there's still a fair bit of racial profiling that still goes on within Newcastle.

... [A]nd it was my experience from working in reconciliation that there was a lot of people in that baby boomer generation that were keen to seek out and understand and appreciate how Aboriginal people were involved in their history and acknowledged that they only knew one side of the story and were keen to embrace that part of our society and our country.

(transcript 57)

The non-Indigenous community has to give and make sacrifices. How else will we build a better world?

In 1993, the city of Newcastle had embraced its leadership role in reconciliation and signed the Commitment to Indigenous Australians. This historic commitment reflected Newcastle's ambition to become a city of reconciliation and to implement a paradigm shift by including Indigenous protocols, place names, and signage in the city's action plans and policies. The negotiations with Newcastle City Council that followed the signing of this document were anticipated as a positive move toward cultural resurgence and the recognition of Indigenous rights. The Newcastle City Council's symbolic signing of a 'Commitment to Indigenous Australians' was a commitment to rectifying past wrongs, acknowledging the contribution of the local Awabakal peoples and subsequent Indigenous populations to the history of Newcastle. The document committed the local government to a 'practical' program recognising Indigenous rights.

The Commitment drew attention to the white settler-colonial landscape and ongoing colonisation of social spaces and public places. Koori leaders intended for a deracialisation of the production of space, which concerned a deracialisation of the protocols around the way space is produced in Newcastle. The Commitment was about a right to Awabakal visibility in the city through the acknowledgement and recognition of unmarked sites and events in the cities racialised colonial history.

The protocols of whiteness had dominated those spaces. The Commitment set out protocols for this new relationship. It drew attention not only to everyday racism, but how whiteness governed Indigenous incorporation in Newcastle, be it the benevolent acts of goodwill or tolerance or overt acts of discrimination (Howard-Wagner 2009). Still today, local Koori discourses provide examples of stereotyping, marginalisation, exclusion, and discrimination as well as white surveillance, power relations, and race privilege. For local Kooris, race difference is not obscured or masked; it is deeply entrenched in society's psyche.

Representatives from local Indigenous organisations established an identifiable and robust presence in the political circles of local government through the Guraki 
Advisory Committee, development of protocols, and self-government models that created a tangible Indigenous political presence in the city and drove tangible change locally. Reconciliation became a means of restructuring the power relations that underlie the production of urban space and reproduced Indigenous/ settler relations within that space. This political strategy of co-option is one that is demonstrated time and again over the years.

The key practical outcome of reconciliation in this city was to be a local treaty. In 1995, the local Indigenous community and Newcastle City Council worked collaboratively to develop a list of proposed actions to implement the Commitment to Indigenous Australians. The historical notes from the discussion forum between Newcastle City Council staff and Indigenous community members held on 31 May 1995 listed 32 issues raised by the Indigenous communities within the Newcastle region and 40 proposed actions. ${ }^{7}$ These came under six headings: land/sacred/development/environment, council services, employment and training, cultural awareness, Aboriginal communities/council liaison, and visibility of the Aboriginal community. The list of practical measures for recognising Indigenous rights locally included the resurgence of the Awabakal language and cultural practices, the conservation of Aboriginal sites and significant places, and the recognition of Awabakal sites, place names, and stories through signage throughout Newcastle. The then Lord Mayor of Newcastle and the general manager of the Awabakal Cooperative 'stressed the importance of turning the intent of the commitment document into practical outcomes for all people of Newcastle'. He agreed that visible plaques would be erected around Newcastle recognising significant local Awabakal sites, names, and stories, and dual signage that used the Awabakal name for places, such as Muloobinbah, alongside the Anglo-Australian place names, such as Newcastle, would be implemented. Actions included the appointment of a Newcastle City Council Indigenous liaison officer, the establishment of an Indigenous consultative committee (initiatives of the previous Council and Lord Mayor), the flying of the Aboriginal flag on Council flagpoles, and the development of an Aboriginal employment strategy (Newcastle City Council 2003). At that time too, local Kooris stressed the need to develop Welcome to Country signs at city gateways and to note Worimi and Awabakal place names on location signs to engender a sense of belonging.

In May 1997, Newcastle City Council commenced drafting a new Commitment to Indigenous Australians known as the Statement of the Commitment by Newcastle City Council to the Indigenous Australians of the community of Newcastle (Newcastle City Council 1998). The document was strengthened in light of federal policy shifts around the time of the 1997 Reconciliation Convention. The document was finalised and signed in April 1998. The document built on the original Commitment to Indigenous Australians that had been developed as a community initiative in 1993. The statement acknowledged that recognition of the history of dispossession and the grief experienced by First Nations peoples as a result of dispossession was a 'vital step towards building a just, common future'. Reconciliation was constructed as those ethical practices that work 
toward 'healing past wounds'. Reference was made to the continuing dispossession of the Awabakal and Worimi peoples. The document also acknowledged the effects of dispossession. It echoed earlier discourses. Reconciliation and Indigenous rights, in the form of a treaty, were discursively constructed as mutually constitutive.

The draft document took nearly 12 months to finalise. The then Lord Mayor Cr Heys and Indigenous Elders signed the document on the steps of Newcastle City Hall. It was a stand at the local level against then Prime Minister John Howard's 'practical' reconciliation espoused by the federal Howard government, which separated the symbolic from the practical. The then Prime Minister's historic speech at the Reconciliation Convention in 1997 was as much a criticism of separate Indigenous rights, such as native title rights, as it was a repositioning of reconciliation. It confirmed the significant shift that had been occurring in not only Federal reconciliation policy, but Indigenous affairs policy more generally. Reconciliation was limited to the issue of Indigenous disadvantage in terms of social and material/structural indicators (Howard-Wagner 2006). Reconciliation policy and discourses also isolated and reconstructed some of the objectives of reconciliation related to Indigenous aspirations as divisive. The then Prime Minister refused to apologise to the generations of First Nations peoples who had been removed from their families and communities as children ('the Stolen Generation'). For example, at the signing of the document, former Lord Mayor Heys, stated: 'I do not find it hard to say sorry for particular sins perpetrated by my culture, including the stolen generation issue.' The statement was in stark contrast to the Australian federal Howard government's refusal to apologise to the 'Stolen Generation' at that time. Reconciliation, as part of the People's Movement for Reconciliation, was discursively linked to reconciling Australia's past concerning the generations of Aboriginal children removed and separated from their families and communities.

It was not until 1 June 1999 that the Guraki Aboriginal Strategic Advisory Committee of Newcastle City Council was established (under s355 of the Local Government Act, 1993). Guraki was given broad terms of reference that underpinned its role as a strategic advisory committee of the Council. The Koori Chair of the Committee described this as furthering of local Commitment, establishing 'a sound and rewarding relationship between Aboriginal peoples and the City of Newcastle' (transcript, former Chairperson Guraki Committee). Guraki's vision and purpose was to facilitate the implementation of the commitment to Aboriginal and Torres Strait Islander Peoples of the City of Newcastle and the process of reconciliation in Newcastle. While Guraki gave Kooris a voice in local affairs and connected First Nations peoples, organisations, and communities to local government, Newcastle City Council has never had a Koori councillor, an associate councillor in charge of reconciliation like Montreal, or Manager of Aboriginal Relations in the city like Vancouver. There has never been a Koori who has held a senior position within the local government. 


\section{Dual signage}

Newcastle City Council committed to recognising Awabakal place names, Stories, and sites through signage. Signage had the capacity to convey Indigenous belonging. Signage had the capacity to increase the visibility of Awabakal place names, stories, and sites important to local First Nations people. By 2001, Council's efforts to erect visible plaques in Newcastle had been fraught with problems. Numerous attempts had failed to get Council to act, so the petitioning of the local Council was decided. ${ }^{8}$ At a Forum on Local Aboriginal Stories, Places, and Names held by the Newcastle Aboriginal Support Group in June 2001, the then Newcastle City Council Indigenous Liaison Officer pointed out that the action plan outlining 'practical' measures for recognising Indigenous rights, put to Council in 2000 along with previous documents, had not been implemented. At that forum it was decided that local government would be petitioned on the matter. The petition read:

To the Lord Mayor and other Councilors of Newcastle City, the petition of particular residents of Newcastle draws to the attention of the Council our concerns about the lack of Commitment on the part of the Council to make visible significant local Aboriginal sites, names and stories for the Newcastle Region. Newcastle City Council has been a leader in Australia with its Commitment to Reconciliation, and action must be taken to ensure this Commitment is visible to residents and visitors. In the spirit of reconciliation, we challenge the Council to act now. We, therefore, request that Council (1) erect visible plaques in Newcastle recognising significant local Aboriginal sites, names and stories; and (2) use the Aboriginal name for places around Newcastle (dual signage), such as 'Muloobinba' as well as 'Newcastle', in appropriate signage.

While gathered at Newcastle's Christ Church Cathedral for the commencement of the annual NAIDOC week march, the petition was signed by over 500 Kooris and non-Indigenous supporters, signatures continued to be collected. Finally, the petition was submitted to Newcastle City Council. On receiving the petition, Newcastle City Council restated its commitment to making visible local Aboriginal sites, names, and Stories and is now undertaking a project to erect dual signage around Newcastle. ${ }^{9}$

In 2013, the Newcastle City Council unanimously supported the Guraki Committee's proposal for eight features of Newcastle, including Nobby's Head, Hunter River, and the port to be given dual names under a plan to recognise Awabakal history.

In 2018, Newcastle City Council trialled dual signage using Awabakal words for landmarks in public signage on the Harbour foreshore. Twenty-five years after the signing of the local document of reconciliation, there is still no dual signage on the sign, including on the sign telling motorists they are entering the city of 
Newcastle. Newcastle was the first city to sign a document of reconciliation. Today, it lags behind Adelaide, Canberra, Montreal, Toronto, and Vancouver in its recognition of significant local Awabakal sites, names, and Stories.

\section{The fragility of hopeful spaces: a 'treaty of the heart'}

Now, I'm absolutely delighted to see that the issue [of a treaty] is being aired here in Newcastle. As I said on radio yesterday, I'm not surprised that it's being aired in Newcastle because so many areas to do with reconciliation and to do with the advancement of Aboriginal people which have started in Newcastle and in which Newcastle has led the way, and absolutely delighted that that's happening here and of course when I was asked to come chair it I was absolutely delighted to do that as well because it's great to be coming home.

If there is going to be reconciliation there must be full acknowledgement of Indigenous rights in this country.

Two of the big problems we've got at the moment are a need to change the Constitution because we don't have any entrenched guarantee against racism in this country. We have a Racial Discrimination Act which is just any ordinary act of Parliament which can be over-ridden by any subsequent acts of Parliament. We also have a clause in our Constitution which allows the Commonwealth to legislate with respect to a race of people and what that constitution doesn't say is that legislation has to be beneficial for that race of people and it can be used to the detriment of people as happened in the Hindmarsh Island Bridge case.

(then Aboriginal and Torres Strait Islander Social Justice Commissioner and Racial Discrimination Commissioner Bill Jonas Hunter Peoples' Inquiry into a Treaty, cited in Newcastle Aboriginal

Support Group 2001)

In this local area we all seem to work together. We always seem to take the first step in bettering people's lives. I'd like to empower you people out there now to all come together and take this big challenge on. We do need a treaty. If we've got to start at a local level, well, let's begin it. I think that's our first step, getting a treaty.

(Zelma Moran Hunter Peoples' Inquiry into a Treaty, cited in Newcastle Aboriginal Support Group 2001)

There's a balance somewhere between the treaty of the heart and the treaty on paper, and I think that it's a part of the community responsibility, at a very local level to work as groups to try and flesh that out. . . . We have to enact that treaty in the community as a group of people and start to stand up.

(Fred Maher Hunter Peoples' Inquiry into a Treaty, cited in Newcastle Aboriginal Support Group 2001) 
The tenuous nature of reconciliation in Newcastle is an example of the fragility of what Coombes, Johnson, and Howitt refer to as 'geographies of hope' or hopeful spaces of postcolonial reconciliation, belonging, and place (Coombes, Johnson, \& Howitt 2013). Twenty-six years on, Coming Together Day and the signing of the first document of local reconciliation are momentary points in Australian settlercolonial history in which Kooris attempted to establish a rights-relationship at the local level. What Koori leaders attempted to achieve was a form of socio-political and cultural osmosis in the governance of the city of Newcastle. They had a vision for enshrining this in a treaty.

In the final year of the federal Council for Reconciliation, and with no progress on a local treaty, a Hunter Peoples' Inquiry into a treaty was called. A one-day event took place at the Newcastle Regional Museum on 4 November 2000. It was the first 'black/white' public inquiry into a treaty at the local level in Australia. ${ }^{10}$ On that day, there was a call for a 'treaty of the heart'. It was envisaged that this could possibly be the first stage in the development of the first treaty at a local level and would also implement one of the 'practical' measures outlined in Newcastle City Council's 'Commitment to Indigenous Australians'. The Lord Mayor and other Councillors were invited to attend the Inquiry. However, only one Greens Councillor attended. For local Kooris, the poor turnout of Councillors confirmed their suspicion that there had been a shift in the local government's support for Indigenous rights, compared to the support received in previous years. For some, the fact that Councillors and Council staff had not attended the forum also suggested that Council had 'reneged' on its commitment.

Dr Bill Jonas, a local Worimi man, who has strong affiliations with the Indigenous community in Newcastle and was the then Aboriginal and Torres Social Justice Commissioner and Racial Discrimination Commissioner, chaired the Forum. ${ }^{11}$ Attendees were invited to talk about their visions, concerns, and any issues relating to a treaty. Written submissions from Indigenous and nonIndigenous organisations that were unable to be represented at the Inquiry were also received. ${ }^{12}$

That day marked a critical moment in Indigenous/state relations and First Nations peoples' relations with the city. It captured the changing political climate in Australia that had been occurring with a conservative government under the administration of then Prime Minister John Howard. While the magnitude of the issues discussed and their significance over the next 20 years could not be foreseen, three very critical matters in Indigenous/state relations were discussed that would play out in ways that never could have been foreshadowed that day: the dire need for a heartfelt treaty; the issue of Constitutional amendment; and how the law, such as the Racial Discrimination Act 1975 (Cth), could be used to the detriment of First Nations peoples.

The report titled 'Let's Get on With I $^{13}$ - Report of the Hunter Peoples' Inquiry into a Treaty' was handed to the three tiers of government on 3 June 2001 (Mabo Day) in a ceremony held in the Lord Mayor's Function Room. Local Elders and 
Indigenous spokespeople addressed officials and handed over the document to the Lord Mayor of Newcastle and local state and federal members of Parliament. In handing the document over to the three levels of government, politicians were brought into the process, and politicians became actively engaged in the issues. By engaging with the political at this level, the media's attention was also engaged positively. The media was drawn into the process because of its attraction to events involving public figureheads and local initiatives.

The Council took no further action after it was presented with the report, a document generated from statements made at and submissions made to the inquiry. While the handing over of the treaty report to the three levels of government took place at an event held in the Lord Mayor's reception room, this was the extent of the then Lord Mayor John Tate's support for a local treaty. At the event, Indigenous Elders and local Indigenous spokespeople encouraged Council to develop a local treaty and reminded the Lord Mayor of Council's 'Commitment to Indigenous Australians'. The Lord Mayor promised to 'give copies of the Report to all Councilors and to discuss the report in Council and look at ways of putting suggestions into action' (Wurreker 2001, 1). The Lord Mayor tabled the treaty report in a Council meeting, and the Council took no further action on the issue of a local treaty. The majority of non-First Nations peoples may attribute this to a shift in leadership and styles of leadership. It could be argued that the bureaucratic process and governmental change stymied outcomes. However, for local Kooris, and some white activists, it was representative of shifting agendas in the governance of Indigenous affairs in the contemporary period.

\section{Moving to 'practical' reconciliation}

While reconciliation could address the enduring invisibility of Indigenous histories, place, and belonging in the city, actions over the last 25 years reveal the struggle and complexities of everyday place-making and transformative reconciliation as a form of resurgent reconciliation (Borrows \& Tully 2018). Reconciliation became a ubiquitous initiative. A benevolent whiteness crept back into reconciliation activities in which Indigenous culture has continued to be trotted out and celebrated in community events. Newcastle City Council now has a Reconciliation Action Plan (RAP), which provides a structured plan to advance the organisation's (or workplace) reconciliation agenda.

While First Nations peoples were looking at reconciliation through the lens of In Newcastle today, the earlier commitments made and documents developed by Newcastle City Council are seen by the local Kooris as largely figurative and historical now. Local Kooris pointed out that the mayor and other officials use elaborate and positive rhetoric in their public speeches about Indigenous issues, including Indigenous rights, referring to the 'Commitment to Indigenous Australians', yet there is little action. One Koori Elder stated that: 'The local Council rather sadly develop these magnificent documents that say all the right words, but when you look at the action there's nothing there' (transcript 1). ${ }^{14}$ Others agreed, and on interviewing local Kooris, this was a common complaint made about the 
Commitment to Indigenous Australians and other symbolic gestures, including speeches, made by the local Council. Koori discourses are critical of the extent to which Indigenous rights to the city have been recognised. As one local Koori stated: 'The non-Indigenous community has to give and make sacrifices, how else will we build a better world?'15

As mentioned earlier, there was a national shift in reconciliation policy, and the meaning of reconciliation had changed at the federal level. In 1997, then Australian Prime Minister John Howard criticised appeals to the past as a precursor for bringing about contemporary change (Brawley 1997). Reconciliation was reconstructed within such precepts. It was no longer about reparations for past wrongs or symbolic and practical gestures recognising Indigenous rights. The old symbolism of reconciliation that recognised separate rights was constructed as divisive. Reconciliation was now limited to symbolic gestures of goodwill, such as the Reconciliation Walk across Sydney Harbour Bridge or Corroboree 2000. Reconciliation was about moving forward as a united nation. Yes, we have a shared history, but 'we' move forward together in unity. Symbolic acts of reconciliation were now those acts that united all Australians. It is the classical liberal principles of tolerance that were enacted in the Howard years. It was an ethics of white Australia. Moreover, the practical measures that put in place Indigenous rights were now obsolete.

Howard went as far as to bring into effect a new policy known as 'practical reconciliation', separating what he referred to as the symbolic and divisive claims of Indigenous rights from the practical needs of First Nations peoples, such as health, education, and employment. Practical reconciliation later came to be described as overcoming Indigenous disadvantage, committing to 'practical programmes of action' that had 'measurable outcomes' (Howard 1997). Howard's positioning of practical reconciliation and disadvantage as the cornerstone of Indigenous policy (Hunter \& Schwab 2003, 83) in the late 1990s forewarned of significant shifts in the governance of Indigenous affairs in Australia. However, no-one foresaw the extent to which the Howard government and successive Australian federal governments would reform Indigenous law and policy and intervene in the lives of Aboriginal and Torres Strait Islander peoples from 1996 onwards. As the former Chairperson of the Council for Aboriginal Reconciliation, Yawuru man and now federal Senator, Patrick Dodson noted, 'a political backlash where reconciliation was redefined by those with political power to mean improved services and economic participation for Indigenous peoples - reconciliation on settler Australia's terms' (Dodson 2018, 5).

Reconciliation had shifted to closing the education, employment, housing, and health gap. The focus turned to Indigenous service delivery. Federal, state, and local governments were partnering with Indigenous organisations to create better services for Closing the Gap. Central to the Australian government's strategy was a new partnership with Indigenous Australians based on mutual responsibility and mutual respect. The Newcastle City Council's RAP instituted into eff ect a policy of 'practical reconciliation' directed at Closing the Gap, particularly in the areas of employment and 'mutual responsibility'. In Newcastle, mutual respect, 
relationships, and engagement were now expressed through the Hunter Aboriginal Interagency Network, the Aboriginal Employment Network, the Muloobinbah Aboriginal Education Consultative Group, and the Muloobinbah Aboriginal Education Consultative Group.

Howard wilfully ignored the constellation of disadvantage experienced by First Nations peoples that are an artefact and legacy of Australia's settler-colonial history and the institutionalised structuring of Indigenous/settler-colonial social relations in Australia over two hundred years (Samson 2013). This act of wilful ignorance denied difference, erased Indigenous agency, invalidated Indigenous histories, and subjected First Nations peoples to further injustices. It did not end with ignoring history and the constellation of transgenerational disadvantage First Nations peoples experience. Fresh wounds were inflicted.

\section{Notes}

1 As Indigenous historian John Maynard notes, 'Robert Smith was heavily involved in trying to improve the provision of Aboriginal health services and was the managing director of the Awabakal Medical Service until ill health forced his premature retirement' (Maynard 2001). Maynard, J. (2001) Muloobinbah (Newcastle) an Aboriginal Industrial Presence: Past and Present, Accessed 24 October 2012 www. thefreelibrary.com/Muloobinbah $+\% 28$ Newcastle $\% 29+$ an + Aboriginal + industrial + pr esence $\% 3 \mathrm{~A}+$ past+and . . . -a080678928 The information contained here is from oral interviews conducted by Professor John Maynard, the Wollotuka Institute, University of Newcastle.

2 Extract from an in-depth interview conducted as part of $\mathrm{PhD}$ research 2000 to 2005.

3 Lefebvre 1943, 1968.

4 While reconciliation in Canada came out of a process of litigation and combining of a number of class actions in which First Nations, Inuit, and Metis peoples mounted legal case against the Canadian federal government and four national churches concerning the longstanding residential school system, reconciliation in Australia came out of the Royal Commission into Aboriginal Deaths in Custody. In 2008, the Truth and Reconciliation Commission in Canada culminated from the largest class action and largest out of court settlement in Canadian history. The Truth and Reconciliation Commission provided a detailed account of what happened to Indigenous children who were physically and sexually abused in government boarding schools. In 2015, it also issued 94 calls to action, including the call for a Royal Proclamation of Reconciliation and the establishment of a National Council for Reconciliation.

5 Nearly 40 years earlier, the Royal Commission into Aboriginal Deaths in Custody (RCIADIC) in 1987 investigated the high rates of Indigenous deaths in custody over ten years following public agitation from First Nations peoples. Its report included 339 recommendations (Johnston 1991). The RCIADIC called for sweeping changes to health, housing, education, access to justice, and even research practices (Johnston 1991). The recommendations of the RCIADIC were extensive, covering selfdetermination to land rights to reconciliation (Johnston 1991). The final recommendation was that the state initiate a formal process of reconciliation between Aboriginal people and the wider community. It set out that 'That all political leaders and their parties recognise that reconciliation between the Aboriginal and non-Aboriginal communities in Australia must be achieved if community division, discord and injustice to Aboriginal people are to be avoided. To this end, the Commission recommended that political leaders use their best endeavours to ensure bi-partisan public support 
for the process of reconciliation and that the urgency and necessity of the process be acknowledged' (Recommendation 339). Following the Council for Aboriginal Reconciliation Act (Cth) coming into force in 1991, which had a ten-year mission, a reconciliation movement that was driven at the federal level took shape. The legislation set out five reasons why the Act had been established, which included that: '(a) Australia was occupied by Aboriginal people (Aborigines is offensive to Aboriginal people) and Torres Strait Islanders who had settled for thousands of years, before British settlement at Sydney Cove on 26 January 1788; (b) many Aboriginal people (Aborigines is offensive) and Torres Strait Islanders suffered dispossession and dispersal from their traditional lands by the British Crown; and (c) to date, there has been no formal process of reconciliation between Aboriginal people (Aboriginnes is offensive to Aboriginal peoples) and Torres Strait Islanders and other Australians.' As set out in the function of the Act, a vital intent of the legislation was 'to promote, by leadership, education and discussion, a deeper understanding by all Australians of the history, cultures, past dispossession and continuing disadvantage of Aboriginal people (Aborigines is offensive to Aboriginal peoples) and Torres Strait Islanders and of the need to redress that disadvantage'. Robert Tickner MP, the then Federal Minister for Aboriginal and Torres Strait Islander Affairs, envisaged a community-based movement for reconciliation and Indigenous social justice (Tickner, 2001, 29). It was also envisaged that a national reconciliation document would be developed, as well as local reconciliation documents.

6 The statement was also made at the HREOC community consultation on racism.

7 The Newcastle Aboriginal Support Group has retained historical documents, letters, briefings, etc., on negotiations over the local Document of Reconciliation and subsequent meetings, as well as various forums, including forums on racism. I was given access to such documents for this research.

8 I attended wearing my researcher's hat and had the consent of all attendees to record and document the event as part of my $\mathrm{PhD}$ research.

9 In 2003, the Local Government Association called on all Councils to display Aboriginal and Torres Strait Islander flags, as appropriate, in the place where the Australian flag was flown (Newcastle City Council, City Strategy Group 2003 - Item 45). In 2003, The Newcastle City Council adopted a motion to fly the Aboriginal flag alongside the Australian flag at City Hall and to permanently display the Aboriginal flag in Council Chambers (Newcastle City Council, 2003 - Item 45). Council also adopted an official Acknowledgement Statement to recognise the dispossession of Traditional Custodians in 2003. An Aboriginal Employment Strategy for the Newcastle City Council was also developed in consultation with the Newcastle City Council Indigenous Consultative Committee. All members of Council endorsed the Aboriginal Employment Strategy in early 2003.

10 Newcastle Aboriginal Support Group (2001) 'Let's Get on With It': The Hunter People's Inquiry into a Treaty, prepared by the Newcastle Aboriginal Support Group. I attended wearing my researcher's hat and had the consent of all attendees to record and document the event as part of my $\mathrm{PhD}$ research.

11 Dr Bill Jonas was a lecturer at Newcastle University and has worked with the local community in a study titled: On the fringes of Newcastle: a matter of people (Hall and Jonas, 1985). Dr Jonas is a Worimi man. The Worimi land is north of Newcastle across the Hunter River, and includes the Newcastle suburb of Stockton within its boundaries.

12 All speeches and submissions were transcribed, coded and presented in a report.

13 'Treaty - Let's Get on With It' was the NAIDOC week theme in 2001.

14 The Human Rights and Equal Opportunity Commission (2001) Racism and Civil Society: A Community Consultation for the World Conference on Racism, Racial 
Discrimination, Xenophobia, and Related Intolerance was held at Newcastle City Hall, Newcastle, on 27 July 2001. The community consultation was part of a national round of consultations in the lead up to the United Nations World Conference on Racism, Racial Discrimination, Xenophobia and Related Intolerance held in Durban, South Africa from 31 August 2001 to 7 September 2001. I attended wearing my researcher's hat and had the consent of all attendees to record and document the event as part of my $\mathrm{PhD}$ research.

15 The statement was also made at the HREOC community consultation on racism.

\section{References}

Alfred, G T (2005). 'Being Indigenous: Resurgences Against Contemporary Colonialism', Government and Opposition, Vol. 40, No. 4, pp. 597-614.

Alfred, G T (2009a). Peace, Power, Righteousness: An Indigenous Manifesto, 2nd Edition. Oxford: Oxford University Press.

Alfred, G T (2009b). 'Colonialism and State Dependency', International Journal of Indigenous Health, Vol. 5, No. 2, pp. 42-60.

Alfred, G T (2013). 'Being and Becoming Indigenous: Resurgence Against Contemporary Colonialism', in 2013 Narrm Oration. Melbourne: Murrup Barak, Melbourne Institute for Indigenous Development at the University of Melbourne.

Alfred, G T \& Corntassel, J (2005). 'Being Indigenous: Resurgences Against Contemporary Colonialism', Government and Opposition, Vol. 40, No. 4, pp. 597-614.

Altamirano-Jimenez, I (2004). 'North American First Peoples: Slipping into Market Citizenship?' Citizenship Studies, Vol. 8, No. 4, pp. 349-365.

Back, L (2009). 'Researching Community and Its Moral Projects', Twenty-First Century Society, Vol. 4, No. 2, pp. 201-214.

Bell, A (2016). 'Decolonizing Conviviality and "Becoming Ordinary": Cross-Cultural Face-to-Face Encounters in Aotearoa New Zealand', Ethnic and Racial Studies, Vol. 39, No. 7, pp. 1170-1186.

Bellerose, B (2017). Neoliberalism and the Evolution of the Urban Aboriginal Strategy in Metro Vancouver. Urban Studies Thesis (M.Urb), Simon Fraser University, Vancouver.

Bergen, R (2013). 'Vancouver Proclaims a Year of Reconciliation with Aboriginal Peoples', CTV News, http://bc.ctvnews.ca/vancouver-proclaims-a-year-of-reconciliation-withaboriginal-peoples-1.1335127\#ixzz2XA0pkmNM, accessed 21 June 2013.

Borrows, J \& Tully, J (2018). 'Introduction', in Asch, M, Borrows, J \& Tully, J (eds.), Resurgence and Reconciliation: Indigenous-Settler Relations and Earth Teachings. Toronto: University of Toronto Press.

Brawley, S (1997). " "A Comfortable and Relaxed Past": John Howard and the "Battle of History", Electronic Journal of Australian and New Zealand History, published online 27 April, http://www.jcu.edu.au/aff/history/article/brawley.htm.

Canadian Broadcasting Commission (2016). 'Making Truth and Reconciliation a Reality in Vancouver, in the Canadian Broadcasting Commission', 13 November, www.cbc.ca/ news/canada/british-columbia/making-truth-and-reconciliation-a-reality-in-vancouver1.3845796, accessed 15 November 2016.

Clark, T (2013). 'Keating's Redfern Speech Is Still Worth Fighting Over', The Conversation, 9 December, https://theconversation.com/keatings-redfern-speech-is-still-worthfighting-over-21118, accessed 7 June 2020. 
Coombes, B, Johnson, J T \& Howitt, R (2013). 'Indigenous Geographies II: The Aspirational Spaces in Postcolonial Politics - Reconciliation, Belonging and Social Provision', Progress in Human Geography, Vol. 37, No. 5, pp. 691-700.

Corntassel, J (2012). 'Re-Envisioning Resurgence: Indigenous Pathways to Decolonization and Sustainable Self-Determination', Decolonization: Indigeneity, Education \& Society, Vol. 1, No. 1, pp. 86-101.

Coulthard, G (2007). 'Subjects of Empire: First Nations Peoples and the "Politics of Recognition” in Canada', Contemporary Political Theory, Vol. 6, No. 4, pp. 437-460.

Coulthard, G (2014). Red Skin, White Masks: Rejecting the Colonial Politics of Recognition. Minneapolis, MN: University of Minnesota Press.

Coulthard, G \& Simpson, L B (2016). 'Grounded Normativity/Place-Based Solidarity', American Quarterly, Vol. 68, No. 2, pp. 249-255.

Danaher, G, Moriarty, B \& Danaher, P (2006). 'Challenging Heterotopic Space: A Study of the Queensland School for Travelling School Children', Studies in Learning, Evaluation, Innovation and Development, Vol. 3, No. 1, pp. 40-51.

Dodson, P (2018). 'Foreword', The State of Reconciliation in Australia: Our History, Our Story, our Future, Reconciliation Australia, Canberra.

Elliott, M (2018). 'Indigenous Resurgence: The Drive for Renewed Engagement and Reciprocity in the Turn Away from the State', Canadian Journal of Political Science/Revue canadienne de science politique, Vol. 51 No. 1, pp. 61-81.

Face, J (2001). Parliamentary Speech NSW Hansard 24 October 2001 - item 45 of 52.

Farmer, P (2004). Pathologies of Power: Health, Human Rights and the New War on the Poor. Berkley, CA: University of California Press.

Farrell, M \& Meehan, D (1997). 'Coming Together Day: Two Looks', in Walsh, P (ed.), Novocastrian Tales. New Lambton, NSW: Elephant Press.

Feagin, J R (2014). Racist America: Roots, Current Realities, and Future Reparations. New York: Routledge.

Foucault, M (2007). Security, Territory, Population: Lectures at the Collège De France, 1977-1978. London: Palgrave Macmillan.

Gilroy, P (2004). After Empire: Melancholia or Convivial Culture. London: Routledge.

Hall, M \& Jonas, W J A (1985). On the Fringes of Newcastle Society-a Matter of People, with a note/by J Doherty. Newcastle, NSW: Awabakal Newcastle Aboriginal Cooperative Ltd in association with the NSW Ministry of Aboriginal Affairs.

Henry, R (2008). 'Engaging with History by Performing Tradition', in Kapferer, J (ed.), The State and the Arts: Articulating Power and Subversion. New York: Berghahn Books, pp. 52-69.

Howard, J (1997). 'Speech Given at the 1997 Reconciliation Convention in Melbourne', 27 May.

Howard-Wagner, D (2006). Post-Indigenous Rights - The Political Rationalities and Technologies Governing Federal Indigenous Affairs in the Contemporary Period. PhD Dissertation, University of Newcastle, Newcastle.

Howard-Wagner, D (2009). 'Whiteness, Power Relations, Resistance and the "Practical” Recognition of Indigenous Rights in Newcastle', Theory in Action, Vol. 2, No. 1, pp. 40-65.

Howard-Wagner, D (2012). 'Reclaiming the Northern Territory as a Settler Colonial Space', Arena Journal, Vol. 37/38, pp. 220-240.

Howell, M (2019). 'Vancouver's Record-Breaking Homeless Population at 2,223 People', The Vancouver Courier, www.vancourier.com/news/vancouver-s-record-breakinghomeless-population-at-2-223-people-1.23853962, accessed 10 October 2019. 
Hunter, B H \& Schwab, R G (2003). 'Practical Reconciliation and Continuing Disadvantage in Indigenous Education', The Drawing Board: An Australian Review of Public Affairs, Vol. 4, No. 2, pp. 83-98.

Johnston, E (1991). Royal Commission into Aboriginal Deaths in Custody: Report and Recommendations. The Commission.

Kirkwood, I (2001). 'Seeds to Form Symbol of Unity', Newcastle Herald, 27 January, p. 8.

Kowal, E (2008). 'The Politics of the Gap: Indigenous Australians, Liberal Multiculturalism, and the End of the Self-Determination Era', American Anthropologist, Vol. 110, No. 3, pp. 338-348.

Lefebvre, H (1943). 'Right to the City (1968)', Writings on Cities, pp. 61-181.

Lefebvre, H (1996). 'The Right to the City', Writings on Cities, pp. 63-181.

Maynard, J (2001). 'Muloobinbah (Newcastle) an Aboriginal Industrial Presence: Past and Present', Journal of Royal Australian Historical Society, Vol. 87, No. 2, pp. 248-266.

Nadasdy, P (2005). Hunters and Bureaucrats: Power, Knowledge, and Aboriginal-State Relations in the Southwest Yukon. Vancouver: UBC Press.

Newcastle Aboriginal Support Group (2001). 'Let's Get on With It': The Hunter People's Inquiry into a Treaty', prepared by the Newcastle Aboriginal Support Group.

Newcastle City Council (1998). 'Statement of a Commitment by Newcastle City Council to Indigenous Australians of the City of Newcastle', http://www.ncc.nsw.gov.au/council/ plans/statements/indigenous.cfm, accessed 2 April 2005.

Newcastle City Council City Strategy Group (2003). 'Item-45 CST 9/12/2003 Permanently Fly the Aboriginal Flag at City Hall', www.newcastle.nsw.gov.au/council/ meetings/papers/mee03_12_09/City\%20Strategy\%20Item\%2045.pdf, accessed 2 April 2005.

Newcastle Herald (1998). 'City Marks Historic Commitment', Newcastle Herald, 15 April, p. 4. www.ncc.gov.au/council/plans/statements/indigenous.cfm.

Purcell, M (2014). 'Possible Worlds: Henri Lefebvre and the Right to the City', Journal of Urban Affairs, Vol. 36, No. 1, pp. 141-154.

Reconciliation Canada (2013a). 'The Language of Reconciliation', https://reconciliationcanada.ca/the-language-of-reconciliation/.

Reconciliation Canada (2013b). 'Leaders Gather in Vancouver for Historic Call to Action for Reconciliation', 1 May, https://reconciliationcanada.ca/leaders-gather-in-vancouverfor-historic-call-to-action-for-reconciliation/.

Rose-Redwood, R (2016). "Reclaim, Rename, Reoccupy”: Decolonising Place and the Reclaiming of PKOLS', ACME: An International E-Journal for Critical Geographies, Vol. 15, No. 1, pp. 187-206.

Rowse, T (2012). Rethinking Social Justice: From 'Peoples' to 'Populations.' Canberra: Aboriginal Studies Press.

Samson, C (2013). A World You Do Not Know: Settler Societies, First Nations Peoples and the Attack on Cultural Diversity. London: Human Rights Consortium, School of Advanced Study, University of London.

Samson, C \& Short, D (2006). 'The Sociology of First Nations Peoples' Rights', in Morris, L (ed.), Rights: Sociological Perspectives. Oxon and New York: Routledge.

Simpson, A (2014). Mohawk Interruptus; Political Life Across the Borders of Settler States. London: Duke University Press.

Simpson, A (2016). 'Whither Settler Colonialism?' Settler Colonial Studies, Vol. 6, No. 4, pp. 438-445.

Simpson, L B (2011). Dancing on Our Turtle's Back: Stories of Nishnaabeg Re-Creation, Resurgence, and a New Emergence. Winnipeg, Manitoba: Arbeiter Ring Publishing. 
Simpson, L B (2016). 'Indigenous Resurgence and Co-Resistance', Critical Ethnic Studies, Vol. 2, No. 2, pp. 19-34.

Stace, T (1999). 'Opening of Yallarwah Place', Worker, Newcastle Aboriginal Support Group Newsletter No. 116, April, p. 1.

Tickner, R (2001). Taking a Stand: Land Rights to Reconciliation. Crows Nest, NSW: Allen \& Unwin.

Tomiak, J (2016). 'Navigating the Contradictions of the Shadow State: The Assembly of First Nations, State Funding, and Scaled of Indigenous Resistance', Studies in Political Economy: A Socialist Review, Vol. 97, No. 3, pp. 217-233.

Trimikliniotis, N (2012). 'Sociology of Reconciliation Learning from Comparing Violent Conflicts and Reconciliation Processes', Current Sociology, Vol. 61, No. 2, pp. 244-264.

Turner, D A (2006). This Is Not a Peace Pipe: Towards a Critical Indigenous Philosophy. Toronto: University of Toronto Press.

Wadham, B A (2004). Differentiating Whiteness: White Australia, White Masculinities and Aboriginal Reconciliation. Canberra, Australia: Aboriginal Studies Press.

Wurreker (2001). Newcastle Aboriginal Support Group Newsletter No. 129, June.

Young, I M (1990). Justice and the Politics of Difference. Princeton, NJ: Princeton University Press. 


\section{White spaces and white adaptive strategies}

\section{Visibility and aesthetic upgrades and Indigenous place and space in the post-industrial city in the neoliberal age}

On 28 August 2017, Montreal City Council unanimously adopted a resolution to endorse the United Nations Declaration on the Rights of First Nations peoples. Montreal, Toronto, and Vancouver were among several Canadian cities to adopt UNDRIP, setting a benchmark for the right to the city. The adoption of UNDRIP was associated with reconciliation. The then mayor of Montreal declared that 'More than ever, cities have a crucial role to play in reconciliation with First Nations peoples, and there can be no reconciliation without respect for rights' (Deer 2017, 1). One month later in September 2017, Montreal's then Mayor Denis Coderre had declared the city a Metropolis of Reconciliation. That day, the mayor and First Nations Chiefs unveiled Montreal's new coat of arms and flag (Ville Montreal 2017). The flag and coat of arms were changed to reflect the city's origins, better establish a 'nation-to-nation' relationship with First Nations peoples, and recognise their importance and fundamental historical contribution (Ville Montreal 2017). The new flag and coat of arms, which included the addition of a white pine tree, was chosen by an advisory committee designated by the Assembly of First Nations of Quebec and Labrador to reflect the history of First Nations peoples and their contribution to the city (Ville Montreal 2017). The pine tree sits alongside the representations of those who founded the city: Fleur-de-lis (French), the thistle (the Scottish), the rose (the English), and the shamrock (the Irish).

In 2018, Montreal elected a First Nations person to Council, Marie-Josée Parent, who was appointed the role of associate councillor in charge of reconciliation (CBC News 2018). Her appointment occurred alongside the renaming of Amherst Street, which is named after the British general who supported giving smallpox-laced blankets to the First Nations peoples living in Montreal in the 1700s (CBC News 2018). The Mayor created a committee of First Nations people to help choose the new name for the street. It preceded a Quebec Summit of First Nations and Municipalities on Reconciliation held on 30 August 2018, which brought together about 50 mayors from across the province along with more than half of the province's First Nations Chiefs.

The participation of First Nations peoples in the removal of symbols of colonial oppression was a powerful gesture of reconciliation. The City of Montreal collaborated with the Mohawk First Nations traditional owners and the wider urban 
First Nations community in the renaming of Rue Amherst or Amherst Street. The collaboration saw the street now bear the name Rue Atateken (Mohawk for 'brothers and sisters'). The city of Montreal had already undertaken other actions within the framework of its reconciliation strategy, such as the naming of Park Tiohtià:ke Otsira'kéhne, toponym in the Kanienke'ha language, following consultation of speakers on behalf of Mohawk communities. It had also declared its plan to increase the use of Mohawk place names in Montreal, support Montreal's Indigenous cultural events, and recognise non-surrendered Indigenous ancestral territory in pronouncements by the Mayor and other city elected officials. Montreal intended to create the position of Commission for First Nations peoples.

The reclaiming of place-identities and reinstating of Storyscapes in everyday spaces and the recognition and protection of significant sites are not merely symbolic acts but an integral part of the reassertion of Indigenous authority over lands and territories in cities (Rose-Redwood 2016, 187). The actions of the City of Montreal are a step toward rectifying the absence of visible Mohawk signifiers (Nesbitt 2017). However, the renaming of signage and recognising First Nations places does not disrupt the dominance of settler-colonial whiteness in this city. Aside from the Hochelaga Rock at the left of the Roddich Gates, which commemorates the Iroquois settlement that stood on the very land that McGill University sits on today, what remains hidden in plane sight is that something lies beneath this modern city (Behrendt 2006, 1). While place names express and insert a regulated Mohawk presence back into place, the act of reconciliation does not restore what lies beneath - Mohawk sovereignty. It does not decolonise the city, bringing about the repatriation of Indigenous land and life. Land rights remain contested.

Carleton notes that 'since the 17th century, Mohawks have attempted all means - from petitions and land claims to blockades - to have their land returned, without success (Carleton 2019, 1). The Oka Land Dispute west of Montreal on the north side of the Ottawa River is a stark reminder of the ongoing conflict and struggle of First Nations peoples. In 1990, the Mohawks of Kahnawake and Kanesatake near Montreal participated in a 78-day revolt known as the Oka Crisis, over the planned expansion of a golf course on to a burial ground. Carleton explains how the provincial conflict escalated, leading to a federal government intervention in which it deployed 2,500 troops (and tanks) to the area as a show of force (Carleton 2019, 1). Carleton also notes that 'the conflict cost Canadian taxpayers an estimated \$200 million' (Carleton 2019, 1). In February 2020, the Mohawks Kahnawake and Kanesatake blocked Canadian roads, joining a national revolt across Canada triggered in support of the Wet'suwet'en's opposition to the construction of a gaslink pipeline through their territory. The revolt included blocking rail tracks across Canada. The mantra was 'Reconciliation is dead, revolution is alive' (Lindeman 2020,1). Protestors drew attention to the 'double speak of the nation' (Lindeman 2020, 1).

The aim of the chapter is to reflect in more depth about the contradictions in relation to reconciliation. I consider what remains hidden in plain sight in terms of the struggle that First Nations peoples engage in around reclaiming, belonging, 
and Indigenous landscape-shaping for and by First Nations peoples in the city of Newcastle (Fenster 2004, 2005a, 2005b). I situate the struggle for First Nations visibility back in place alongside the struggle for the protection of significant sites and land claims to reveal how the recognition of place names does not necessarily entail a re-seeing of the land and a respecting of First Nations homelands. In this chapter, I illustrate this point through reference to the re-development of Newcastle's previously disused and industrial foreshore.

The chapter contends with the other side of reconciliation not discussed in Chapter 5, which is the white settler-colonial city and the practices of those who govern it, providing some insight as to how the possessive investment in whiteness hinders transformative reconciliation in the city of Newcastle. The chapter aims to explain how the city operates as what sociologist Elijah Anderson refers to as an 'overwhelmingly white space' (Anderson 2015). Whiteness is deeply entrenched in the psyche of this city. It is a wider reference to urban transformation of the city in the neoliberal age, while at the same time rendering visible the social practices of whiteness in settler-colonial cities. The chapter demonstrates that settler colonialism in cities is not a historical artefact or part of a nowconcluded historical past (Coulthard 2014; Hugill 2017, 5). Settler cities remain settler-colonial entities today in which 'settler-colonial dynamics continue to shape interactions between settler and Indigenous constituencies in the present' (Hugill 2017, 5). First Nations peoples continue to be displaced by development in cities.

Indigenous invisibility and alienation also concerns how city polities are governed. There are associated complexities in terms of how law and policy are administered in cities. The central point of analysis in this chapter is how Indigenous sovereignty continues to be disregarded, displaced, invisibilised, alienated, and estranged in the governing of settler-colonial cities. Of course, who governs, how cities are governed, and the dynamics with First Nations peoples can shift and change over time. Formally too, while cities are a single administrative division that has corporate status and power of self-government and jurisdiction, they are subordinate to state or provincial and/or federal laws, policies, and institutions. For example, development in cities is regulated differently across states/ provinces in the federal systems of government in Australia, Canada, and the United States. There are many activities carried out by public authorities that do not require development consent. Depending on the development, there are development assessments and decisions that occur at either the local or state level. There are some circumstances in which developments can trigger federal laws. City development on significant Indigenous sites in and of itself remains a highly complex and contested space. An important aspect of the work of making these processes and their outcomes visible lies in critically examining how the settlercolonial city is constituted and normalised. It requires exposing the processes and outcomes of meaning-making and space-making that displace Indigenous knowledges and territorialisations (Tomiak 2016, 11). It does so while rendering First Nations peoples as agents of territorial contestation and telling those stories too. 
It avoids what Glen Clouthard describes as an 'urbs nullius' perspective - 'urban space void of Indigenous sovereign presence' (Coulthard 2014, 176). While more often than not, Indigenous sites do not get protected, and development goes ahead, there are the exceptions. However, in most cases, development and planning in cities continue to dispossess traditional owners of their land and to create tensions (Porter \& Barry 2016). Janoschka and Sequera expand the concept of displacement as a process of dispossession. Displacement as dispossession is not limited to the loss of place, but also involves the destruction of cultural practices, reappropriation of heritage, and marketisation of commonising practices (Janoschka \& Sequera 2016).

\section{The possessive investment in whiteness as property in a post-industrial neoliberal city}

With the closure of the major industry BHP Steelworks in 1999, the Australian city of Newcastle launched into the new century as a post-industrial city, ending an era of heavy industry. While it remained a major Australian coal mining and export hub, it was to transform from a working-class, former steelworks town into a smart, liveable, and sustainable global city with the focus on markets, business, enterprise, entrepreneurialism, and the redevelopment of land. The purpose of urban renewal has been to facilitate Newcastle's economic survival in a postindustrial 21 st century in the neoliberal age. Newcastle's competitive edge is its waterfront foreshore and the cultural activities of young activists and the enterprising heterotopic festival spaces they have created in this city, such as This Is Not Art, Cultural Stomp, Shoot Out, and other events. Within 11 years, Newcastle would become one of Lonely Planet's top ten global travel destinations in 2011 (Westbury 2015). Cultural spaces had become one of Newcastle's commodities. Like Perth and Canberra, Newcastle's planners and local government set about bringing people back into an abandoned city of empty shopfronts. The city created three distinct culture precincts, including the existing civic and cultural precinct, the foreshore, and the University of Newcastle. Public spaces were commercialised. Urban renewal saw 50 hectares of uninhabited industrial dockland reclaimed as foreshore living, like Liverpool and Manchester in the United Kingdom. The transformation of Newcastle has centred around replacing the wasteland of heavy industry including railway workshops, wool stores, cargo sheds, and warehouses along Newcastle's Hunter River foreshore with 50 hectares of new multi-story residential and commercial buildings with ground-floor retail and restaurant/cafe space. Mixed-purpose buildings line the foreshore with between 10 and 20 metres of public space between the buildings and the riverfront. Cultural revival and associated commodified activities were central to the process in Newcastle. The Honeysuckle Development, as it is formally known, has been funded with $\$ 100$ million from the Commonwealth/State Building Better Cities program. The formerly disused foreshore was 'rejuvenated'. It is now the city's 'harbour front playground'. ${ }^{1}$ Alongside the Honeysuckle precinct are the city and 
cultural precincts, which have themselves gone through a significant transformation. There is now a light rail system and buzz of activity along Newcastle's main Hunter Street.

Public art, signage, and recognition of Awabakal place names add value to the cultural precinct and foreshore. The occasional reference to Awabakal occupation and history can be found on a few official interpretive signs alongside detailed white histories at local monuments. If one catches the ferry across the harbour from Newcastle to Stockton, one's attention may be drawn to the decorative sign with the word Muloobinba written on it. Muloobinba is the Awabakal name for Newcastle. Walking along the newly gentrified Honeysuckle precinct foreshore you may notice the public art shaped in the form of cement ships with Awabakal place names carved into them. Walking along the foreshore you may trigger the sensor in the smart technology used to capture recordings that pronounce the Awabakal words for landmarks as you pass signs listing their Awabakal names including the harbour, Whibayganba (Nobby's Headland), Coquun (Hunter River), Khanterin (Shepherds Hill) - and traditional stories of each place. ${ }^{2}$

At the end of the Honeysuckle foreshore precinct, on the corner of Stewart Avenue and Hunter Street, you will see a mural painted by Melbourne artist Matt Last. It is an image of Aunty June Rose with her granddaughter Nayeli Green. The mural was unveiled in December 2018 - 25 years after Newcastle City Council signed the Commitment to Indigenous Australians. It reflects 'the passing on of culture, generation to generation'. Aunty June Rose is the main subject of the artwork in recognition of the decades of volunteer service she has performed as one of the founders of the Awabakal Cooperative. The mural incorporates into its backdrop the art of Raymond Kelly Jnr, Ms Rose's grandson. The backdrop painted by Raymond Kelly Jnr depicts the lakes, rivers, and ocean in the Newcastle region. The word Thirrilmun is written in large letters in the top left-hand corner of the mural, which means 'Brown Treecreeper', a type of woodpecker, in the language of the Awabakal people and is a women's spiritual totem. The main Awabakal totem of the area, the Eagle Hawk or wedge-tailed eagle, which has special significance for the Awabakal people, is also depicted. The revitalisation of public space in Newcastle is not only cast as a place to remember but also a place to recognise the ongoing connection of First Nations peoples to the city and their significant place within the city. Public art, signage, and recognition of place names is a gesture toward recognition that brings First Nations peoples back onto the land they were historically vanished from, making visible First Nations peoples' relationship with and to place in the present moment. Awabakal nation and First Nations peoples become visible in their own territory once again. It also value adds to the neoliberal city.

What is wilfully ignored is how the reclaiming of place-identities and reinstating of First Nation presence in everyday spaces and the recognition and protection of significant sites are not merely symbolic acts but an integral part of the reassertion of Indigenous authority over lands and territories in cities (Rose-Redwood 2016, 187). The localised, situated struggles that involve active engagement in 
the exercising of an Indigenous right to the city through the reconstruction and decolonisation of urban spaces and the surrounding landscape. The acts of placemaking that are political and key strategic devices in the assertion of a right to the city involve the resistance of whiteness, power, domination, and racism (HowardWagner 2006).

In Newcastle, monumental 'white' sites have been built on significant unmarked Awabakal sites. Local Kooris give many examples of contemporary architecture built on Awabakal sites that have their own significant Awabakal history. Newcastle's Christ Church Cathedral is built on Newcastle's pinnacle in a prime location that looks out over the harbour and ocean. If you approach Newcastle from the water you can see that it holds the most dominant place on Newcastle's landscape. The same site was a significant Awabakal Corroboree site. Local Kooris refer to it as a site of dispossession. One local Koori woman noted: 'It was a Corroboree site, and the Church took the land to stop what they saw as Awabakal paganism. The Church often did this' (Howard-Wagner 2009, 43). However, there is no recognition of such.

Newcastle, like all other settler-colonial cities, has a passionately guarded settler-colonial presence embedded in the built environment. This is represented by First Nations peoples as a 'colonisation of the landscape' (transcript 1). The Obelisk in Newcastle, statues, and monuments commemorate fallen soldiers, mercantile marines, and the deeds of British and Australian explorers and governors. Koori discourses mark practices of settler colonisation, explaining how settler-colonial whiteness has imposed itself on the history and landscape of the Awabakal nation for over 200 years in a way that marks itself as legitimate and normative.

The seemingly crucial act of naming and recognising Awabakal sites as an act of reconciliation implores acknowledgement not simply of cultural diversity but of the originating act of colonisation. Newcastle was not just an empty space waiting to be named. As Carter reminds us, the act of naming renders spaces habitable, establishes boundaries and markers, the grid on which European history is grounded (Carter 1987). The recognition of Awabakal sites, Stories, and place names will reveal the markers that map an Awabakal presence. It will render Newcastle or Muloobinbah a different socially inhabited space: a humanised space, not an unknown void. The demand for recognition of Awabakal sites, Stories, and place names challenges the fact that the mapping of modern Australia took place on empty ground: terra nullius. The act of naming and recognition of Awabakal sites, Stories, and places contests domination because it involves recognising that there exists a history before colonisation and that occupation of the land is based on dispossession of the Awabakal people. The act of naming for local Kooris is a 'practical' measure for recognising Indigenous rights. From an Indigenous standpoint, this process entails 'articulating an explicitly normative spatial politics of toponymic activism with the aim of "doing something about injustice in a real sense" (Alfred \& Corntassel 2005, 105; Rose-Redwood 2016, 201-202). 
The signage and public art along the Honeysuckle foreshore have not come easily. Their presence also obscures the broader dynamic taking place between First Nations peoples and the city. In 2001, Newcastle City Council built Bather's Way, a walk along the coastal foreshore of Newcastle' major beaches. In the lead-up to the building of the site, the Guraki Committee informed the Council that there was a significant Awabakal history of connection to the area depicted in a number of Awabakal Stories, and it recommended that Council provide interpretation signs that informed users and visitors of this. According to one local Koori's account of the discussion, it was suggested that the known Awabakal Story about the giant black kangaroo be referenced in interpretive signage. A large interpretive sign at Nobby's Beach marking 'Bather's Way' was erected stating that 'the local Aboriginal people, the Awabakal, believe Nobby's Island was created in the Dreaming by the great Rainbow Serpent as it pushed itself onto the land after it had dropped from the sky into the oceans'. The signage was wrong. According to many local Kooris, the Rainbow Serpent myth is not a known Awabakal story:

Interviewee: Newcastle City Council, totally well-intentioned I'm sure, put signage up along the coast.

Interviewer: Is that part of the Bather's Way project?

Interviewee: Yeah! They have a lovely sign up at Nobby's Beach telling people that the Awabakal people believe the Rainbow Serpent came down and created the harbour. It's bullshit. It's not true. It's not true at all. The Awabakal peoples, as far as we are aware, didn't have a consciousness of the rainbow spirit. They had a consciousness of the giant black kangaroo inside Nobby's.

Pan-Aboriginal myths were substituted for local Awabakal Dreaming Stories. The visible signs of this reconciliatory act mask how the development of the foreshore has played out in complex ways with First Nation peoples. Local Koori discourses render dominant accounts of history as problematic through an effective history, exampling how 'The history of some is not the history of others' (Foucault 1976, 69).

Paradoxically, while Newcastle's foreshore development has made visible Awabakal history, language, and place names, it has also desecrated Awabakal sites and artefacts. The redevelopment of post-industrial Newcastle has created new forms of displacement and is a new site of struggle and source of territorial contestation and conflict.

\section{The politics of Indigenous land claims}

The excavation of many of the development sites along the Honeysuckle has unearthed significant Awabakal artefacts. The Ibis hotel, the Kentucky Fried Chicken fast-food restaurant, the new inner-city university site, and the Newcastle light rail corridor are all separate sites on the main street along the city 
foreshore where significant Awabakal artefacts, such as stone tools and campsite remains have been discovered during the excavation phase of development (Kelly 2011a, 2011b, 2015). ${ }^{3}$ The site on which Kentucky Fried Chicken fast-food restaurant is now located on Hunter Street is 'one of the country's most significant cultural heritage sites' (Kelly 2011a). The restaurant was built at 684 Hunter Street on the former Empire Palais Royal site. The Palais had been demolished in 2008 after it was damaged during the 1989 earthquake and a severe storm hit and flooded Newcastle in 2007. In 2011, archaeologists recovered over 5,534 Awabakal artefacts, representing three Aboriginal occupation periods dating from 6,716 to 6,502 years BP (before present) (Archaeological and Heritage Management Solutions 2011). They identified the site of 'high to exceptional cultural and scientific significance', drawing on historical paintings to identify the site connection with Awabakal people at the time of colonisation (Archaeological and Heritage Management Solutions 2011). After the Awabakal people had been removed from the land and placed on the first government mission, a government farm had been established on this significant Awabakal site, then a Meatworks and Elite Skating Rink (later the Empire Palais Royale dance hall) was built on it.

Despite the existence of significant Awabakal artefacts, the construction of a Kentucky Fried Chicken restaurant went ahead. It is next door to the Ibis Hotel, which also had been built on Awabakal artefacts. In 2001, on the same site, the Ibis Hotel would be built on, there had been a comprehensive archaeological test and salvage excavation at 700 Hunter Street in Newcastle, which found a large number of Aboriginal stone artefacts, including 'upwards of 4,000 flaked stone artefacts' (Douglas, Tuck, \& Steele 2001, 12). Douglas, Tuck, and Steele suggested that 'the excavated site evidence demonstrated the place was subject to repeated Aboriginal visitation and use in the past for a range of purposes including tool manufacture, maintenance and/or replacement, along with a range of other activities including food procurement, consumption and discard' (Douglas, Tuck, \& Steele 2001, 13). ${ }^{4}$ There are powerful racialised messages conveyed about the ongoing practices of settler-colonial whiteness in cities in the buildingover of Indigenous sites.

The excavation of the former convict lumberyard in inner Newcastle city at the eastern end of Hunter Street uncovered remnants of the convict-built brick walls from the early 19th century. Hundreds of artefacts dating back to the first days of the Newcastle Penal Settlement were found during an extensive archaeological dig between 1989 and 1992. The site was turned into a historical site of significance and listed on the New South Wales State Heritage Register and listed on the Register of the National Estate. The City of Newcastle now owns the site as an urban park. In 2001, the Newcastle City Council erected large interpretive signs around the heritage-listed convict forge site. During the 1989 archaeological dig, Awabakal tool-making objects were discovered in a small section of the site (Bairstow 1989, 18). The site itself is a known Awabakal tool-making site. 
However, as the following account given by one community spokesperson demonstrates, the original interpretive sign made no mention of this:

I said to $\mathrm{Y}$ the other day, I said what's that sign up there $\mathrm{Y}$, it does indicate they also found a campsite over there. And he said: "Only because I got up them. They had to have the time changed." The first sign made no mention of Aboriginal people, and what he was upset about was that the claim was that it was the first site of industry in Australia because of the convict forge, etc. Well it was the first site in European history. So, he had that changed for a start because Aboriginal people were making spears, etc., at that site.

What this example demonstrates is how the Newcastle City Council has placed white history above and beyond Awabakal history. The convict artefacts are memorialised and turned into a park. Awabakal artefacts become secondary and an add-on or, as in the case of 684 and 700 Hunter Street, again desecrated by Western architecture. The settler-colonial city not only engaged in act of erasure, building western architecture over Awabakal artefacts but also economically benefitted from this act.

\section{Aboriginal land rights}

Disrupting the excavation of the sites containing Awabakal artefacts and the broader economic benefits associated with their destruction, the Awabakal Local Aboriginal Land Council placed several land claims over the foreshore areas, including the Newcastle port entrance and the Newcastle-Wickham rail corridor where the new light rail infrastructure was about to be built. As the then CEO of the Awabakal Local Aboriginal Land Council stated, this was 'not a land grab; [local First Nations people were] simply using the Land Rights legislation to claim back land and water that was taken from [them] when white settlement occurred' (Slee cited in Kelly 2015, 1). While claiming the rail corridor was to protect significant Awabakal sites, claiming control of Newcastle's harbour entrance concerned financial independence for local First Nations peoples. The claim made visible how laws pertaining to both Aboriginal Land Rights and Aboriginal heritage protection in the state of New South Wales had failed First Nations peoples in regard to both protecting Aboriginal cultural heritage and economically compensating First Nations peoples for dispossession, highlighting how local First Nations peoples continued to be invisible in relation to the "millions of dollars in royalties from coal sourced from traditional lands and exported through the port' (Slee cited in Kelly 2015, 1). The land claim drew attention to the contemporary paradox of urban transformation in the neoliberal age, illustrating how it has produced Indigenous displacement from land and economic processes. It continues to perpetuate the historical injustice of the economics of settler colonialism in that the flow of development and capital continues to feed the economy of the coloniser while continuing to displace First Nations peoples. 
The claim also brought to the fore how spatial jurisprudential injustice played out through the contradictions of urban land development and urban land rights. Local land disputes continued. While land and title could potentially be powerful mechanisms for changing the political positionality of First Nations peoples in this city, they lacked land development rights over wider public assets. The efforts of the Awabakal Local Aboriginal Land Council to claim vacant crown land as reparation for historical dispossession of land under the NSW Land Rights Act 1983 remained highly contentious. The vacant crown land that was available to be claimed as compensation for land dispossession under the Act did not consist of undeveloped and unused land. The Awabakal Local Aboriginal Land Council found itself in a position of making claims of over historic buildings and iconic sites, such as the Old Sailor's Home on Scott Street in 2001, the former Newcastle Post Office building in 2014, Newcastle's King Edward Headland Reserve, and the former Burwood Colliery Bowling Club site. These disused heritage-listed buildings or sites were in major disrepair. It was estimated that the restoration of the Old Newcastle Post Office would cost approximately $\$ 15$ million. The transfer of the ownership of the Old Sailors' Home and the Old Newcastle Post Office into the hands of the Awabakal Local Aboriginal Land Council also caused major tension within the wider mainstream community. It was only after 17 years of major conflict in the case of the Old Sailors' Home and four years in the case of the Old Newcastle Post Office that the Awabakal Local Aboriginal Land Council was able to sell the two heritage-listed buildings. The Awabakal Local Aboriginal Land Council sold the Old Newcastle Post Office to a developer for \$3.5 million. It was only made possible with a unanimous vote by Awabakal Local Aboriginal Land Council members. Today, $\$ 3.5$ million equates to the capacity to purchase approximately six or seven houses as First Nations community housing properties.

Land ownership in this context emerges from the compensatory system of land rights in New South Wales established under the NSW Aboriginal Land Rights Act in 1983, which differs from land rights in, say, Australia's Northern Territory and Australia's native title regime. The abbreviate NSW Aboriginal Land Rights Act was a legislative space aimed at providing justice to the Aboriginal peoples in the state of New South Wales in Australia. As an economic model, its intent was to provide for economic development through the acquisition of land. At the time of its introduction, the NSW Aboriginal Land Rights Act was considered to be 'an important milestone in the recognition of NSW Aboriginal peoples' rights to land and to compensation for the dispossession of that Land' (NSW Aboriginal Land Rights Act Review 2012 Working Group Report). Its intent was to enable economic development through land. In regard to the management of acquired resources and wealth, the legislated owning bodies of the freehold land acquired under the Act are Local Aboriginal Land Councils.

Many land councils have found themselves asset rich but cash poor. The scheme has only achieved its objectives in limited cases. The Worimi Local Aboriginal Land Council, the Darkinjung Local Aboriginal Land Council, and the Gandangara Local Aboriginal Land Council are the only local Aboriginal Land Councils 
to have established viable enterprises (NSW Ombudsman 2011, 49). The Worimi Local Aboriginal Land Council has invested in local tourism and sand mining on its freehold land. The sand mine 'has the potential to provide income to the LALC for the next 70 years' (NSW Ombudsman 2011, 49).

Recognition of their economic acumen also positions successful local Aboriginal Land Councils as major industry stakeholders and affords them a high degree of political power in their local areas. The Darkinjung Local Aboriginal Land Council is the largest landholder in the two local government areas that its boundaries encompass. The Darkinjung Local Aboriginal Land Council has established a large residential subdivision on an area of land that it owns, which will lead to the sale of over 100 residential lots of land. The Darkinjung Local Aboriginal Land Council has also initiated a significant housing development in the area for nearly 300 manufactured homes. The total equity of the Darkinjung local Aboriginal land council is around $\$ 50$ million (Darkinjung Financial Report 2018). Its mandate under the NSW Aboriginal Land Rights Act 1984 is to use the gains generated from the acquisition of land to overcome Aboriginal disadvantage and promote Aboriginal wellbeing locally.

The Darkinjung Local Aboriginal Land Council also holds a prominent place in the psyche of the mainstream community in the local government areas have since amalgamated into one, and its Chief Executive Officer is regularly quoted in the local media. The Darkinjung Local Aboriginal Land Council is considered the go-to body for Aboriginal governance in the area. It has forged significant relationships with business leaders in the area. It has, for example, entered into a Memorandum of Understanding or Principle of Cooperation's Agreement with Gosford Local Government, recognising the local Aboriginal land council as a key decision-maker within the local community. It has negotiated land claims with the state and local government. It has entered into cooperative management agreements about the management of local reserves. Its engagement with development processes in the region has nonetheless been fraught. Its capacity to engage in development has been mired by red tape imposed on it under the Land Rights Act, and it has missed many development opportunities. It has also had significant opposition to development. One of its proposed housing developments received the greatest number of objections. Many of those objections contained racist content.

In Newcastle, the emancipatory possibilities of land rights claims have been predominately countered with oppositional discourses. The mainstream media has constructed local Aboriginal land claims as ruptures within society. ${ }^{5}$ Crown land was seen as a public asset. Headings such as, 'City under siege', 'Sacred sites - Land claims may tie up waterways', 'Handover of disused building sparks row on native title', 'A fear of friction', and 'Fighting on the beaches' have dominated print media headlines about local Aboriginal land claims. It has exposed a form of hypocrisy in reconciliation in a city that apologises for the past, while its non-Indigenous occupants continue to object to Indigenous land rights in its complicated, imposed western liberal form. 


\section{Invisibility, displacement, alienation, and estrangement in place}

There are not only deep wounds and unfinished business in cities, but injustice and racism that go with 'the possessive investment in whiteness' (Lipsitz 1995). Colonialism is maintained with the ongoing presence of statues and memorials that commemorate figures who engaged in not only atrocities but also those who brought into place oppressive and racist policies during the history of the nation. Yet, injustice and colonialism are also perpetuated through the building of modern architecture over Indigenous sites. Cities not only have a deeply racialised settler-colonial histories, but they remain contested spaces in which there is ongoing conflict over development, which creates new racial dynamics that reinforce the marginalisation of First Nations peoples. Today, the extraction of resources and construction of stadiums to commercial development to housing developments continue to destroy tangible and intangible Indigenous cultural heritage from artefacts to burial sites to cultural landscapes in cities. The privileging of what Cheryl Harris refers to as 'whiteness as property' continues to colonise Indigenous sites in cities (Harris 2003).

However, there are moments of contestation that successfully disrupt the essentialised episteme of judicial and political imaginations, setting a new precedent (Andersen 2005). In 2012, the NSW Joint Regional Planning Panel approved a housing development abutting the Awabakal Butterfly Cave, which has been a significant women's meeting and ceremonial site for thousands of years. Awabakal women still use the cave and the area around the cave for women's business. The site is located in the local government area of the City of Lake Macquarie; Awabakal nation encompasses two local government areas. There are a traditional journey path and Songline with traditional stone arrangements, healing plants, herbs, and seeds in the area surrounding the Butterfly Cave. The Awabakal Butterfly Cave was given a 20 -metre radius from the housing development, and a road was to be constructed 10 metres from the cave. The traditional journey path to the cave and the Songlines were to be built over. Traditional stone arrangements would be destroyed. Awabakal women pointed out that the bushland would go and 'all the healing plants, herbs and seeds on the way that are important to us . . . and the stories that go with them' (Brown cited in McMillan 2017, 1). In 2013, the Awabakal Butterfly Cave was declared an Aboriginal Place under the NSW National Parks and Wildlife Act 1974, as the state of New South Wales did not have separate Aboriginal cultural heritage legislation at that time (McMillan $2017,1)$. It was the first women's place to receive such recognition. It was also the smallest Aboriginal place recognised under the Act. Later, the relevant NSW Minister made a declaration of protection over the site, which only protected the cave within 20 metres of its centre and not its cultural context (McMillan 2017, 1). While the action to protect the Awabakal Butterfly Cave was the first time in 17 years that a Minister has issued a declaration under the Act, the declaration did not protect the traditional journey path and Songlines or the bushland; nor did it 
afford the women's privacy at the cave. Awabakal women wanted an extension of the curtilage. The Awabakal women launched a national campaign on change.org, Facebook, Twitter, and Instagram, seeking public support for the protection of the site. The change.org petition attracted over 30,000 supporters. The Awabakal Local Aboriginal Land Council became involved, and the state floated proposals to exchange the land for other Aboriginal land held by the Land Council. The NSW Environmental Defenders Office also became involved and engaged a heritage expert to prepare a report (McMillan 2017, 1). At one stage, there was a proposal for the state to buy back the land from the developer, but this never eventuated (McMillan 2017, 1). In 2018, the NSW Aboriginal Land Council lodged an application for protection under the Aboriginal and Torres Strait Islander Heritage Protection Act 1984 (Cth) with the federal Minister for the Environment. On 31 January 2019, the federal Minister for the Environment made a section 10 declaration under the Aboriginal and Torres Strait Islander Heritage Protection Act 1984 (Cth) (Kelly 2019, 1). The declaration extends to activities outside the area of the cave that could impact on the cave and the women's ability to conduct ceremonial business on the site, including drilling and land clearing that could disturb soil or vegetation and the removal of vegetation around the cave that would increase the visibility of the area. The declaration has a sunset clause dated 1 April 2029.

In 2015, if it had not been for a landmark judgement of the NSW Land and Environment Court, overturning the NSW government's approval of the development, the extension of the Rocla Calga Sand Quarry in the Gosford city area would have been built on a 'Songline superhighway' ${ }^{6}$ In that case, Rocla had proposed expansion of its Calga sand mine located in what was then the local government area of the City of Gosford to the immediate south of Newcastle. It was not the then local council of the City of Gosford that granted approval for development. The development had been approved by the NSW Planning and Assessment Commission on the recommendation of the NSW Department of Planning. It was the Commission's decision that was challenged in the NSW Land and Environment Court by the Darkinjung Local Aboriginal Land Council.

The development itself had attracted significant social protest, including Blockades at the gates of Rocla's Calga sand mine and a Save the Walkabout Park Festival. The development was contested for its potential impact on the environment too, including the water table and a local aquifer. It posed a threat to the endangered spot-tail quoll. It posed a threat to popular tourism attraction and business in the region - the adjoining Australian Walkabout Wildlife Park. Those matters had been well articulated at a public hearing of the NSW Planning and Assessment Commission that I attended in Peats Ridge in November 2013. However, it was the impact that the development posed to a significant Indigenous cultural landscape that led to the court upholding the Darkinjung Local Aboriginal Land Council's appeal under the Environmental Planning and Assessment Act 1979 (NSW).

In Darkinjung Local Aboriginal Land Council v Minister for Planning and Infrastructure \& Anor [2015] NSWLEC 1465, Dixon C and Sullivan AC of the 
Land and Environment Court of NSW recognised that the site is part of an Aboriginal cultural landscape. The site is immediately connected both spatially and symbolically with other significant sites, such as sites at Mooney Mooney, Baiame Cave, and Mt Yengo. It is a significant site of women's business and is also part of a larger significant symbolic and ritualised cultural landscape associated with Dreaming Stories (NSW Government 2020). It is known as the site where Daramulan came into being and is connected with the belief systems of Baiame, Bootha, and Daramulan. Baiame, Bootha, and Daramulan are significant to First Nations peoples across much of south-eastern Australia as the Creator God and Sky Father who came from the sky and the Mother and Son who created the earth and other beings who passed down sacred law to First Nations peoples (NSW Government 2020). The 2015 judgement of the NSW Land and Environment Court overturned the NSW Government's approval of the development. The evidence given by First Nations women, specifically that given by Guringai First Nations woman Tracey Howie, factored significantly in the Court's findings (Howie, quoted in Dixon \& Sullivan 2015, 4). The decision set a historic landmark precedent in the way that Aboriginal cultural landscapes with tangible and intangible values are recognised and protected in law in the state of NSW (Gordon cited in Barnes 2015, 1).

Again, if it had not been for an Alameda County judge denying a petition for a mandate in October 2019, a developer would have built on about 28,000 square feet at the city of Berkeley's 1900 Fourth Street location, also known as the West Berkeley Shellmound. In Ruegg \& Ellsworth v City of Berkeley and City of Berkeley Department of Planning and Development, Superior Court of the State of California County of Alameda, the city was sued for rejecting a development project in 2018. ${ }^{7}$ The applicant declared the City of Berkeley's decision was 'unlawful'. The decision of the City of Berkeley to list the West Berkeley Shellmound as a City of Berkeley landmark had already been challenged in 2000. The City's decision to designate the West Berkeley Shellmound as a City 'landmark' did not in itself prevent any development or use of the property affected; instead, it prevented additional mechanisms for any new building or alterations to the buildings in relation to the protection of the area.

The West Berkeley Shellmound is a sacred Ohlone burial site. The Ohlone peoples in the San Francisco Bay area have long struggled for the protection of Shellmounds in the area of West Berkeley (McLeod 2018). The West Berkeley Shellmound covers a two-block area that stretches from Berkeley's Hearst Avenue to University Avenue and Fourth Street to Second Street. In 2000, the site was landmarked a Shellmound by the City of Berkeley. A larger area extending west toward the Bay and east to Fifth Street is listed in the California Register of Historical Resources because archaeologists had found cultural and natural deposits that indicated an Ohlone Village settlement. The West Berkeley Shellmound and Village Sacred site date as far back as 5,700 years old.

Over centuries, despite concerted struggles to protect their ancestral burial grounds, sacred graves have been destroyed, subjected to toxic waste dumps, and 
shrunken to a small 2.2-acre area of what is now the parking lot (McLeod 2018). The site is located in a newly gentrified part of Berkeley, which now houses upmarket restaurants, retails shops, and office spaces. In the late 1800s, the mounds were partly destroyed to make way for an amusement park and dance pavilion (McLeod 2018). In the 1920s, a paint factory was built on top of the mounds (McLeod 2018). Toxic waste produced by the factory was left in the ground even after the factory was removed (McLeod 2018). In 1997, a mall was proposed on top of the remains of the Shellmounds, and despite protests, a retail mega-centre was built and continues to be in use today (McLeod 2018). Developers applied to build a five-story mixed-use building on the 2.2-acre Shellmound site on which a carpark and Berkeley's oldest restaurant, Sprengers Seafood, stood. The land was covered but undisturbed. In 2016, it became known to the Ohlone people that the developers planned to turn the current site and adjacent building into apartments, stores, restaurants, and a six-level parking garage. Ohlone remains had been found during a pre-development excavation of the site next to Sprengers Seafood Restaurant at 1919 Fourth Street in March and April 2016 (McLeod 2018). In the 1950s too, a University California Berkeley archaeological dig had unearthed 94 human remains and thousands of artefacts at the site (McLeod 2018). The site had been listed in 2003. With their ancestors remains again disturbed in 2016, the Ohlone First Nations people engaged in a struggle to protect the site from further disturbance. The latest struggle began with a prayer vigil in March 2016 following the pre-development excavation of the 'cemetery of their ancestors'. While it had remained confidential that more than 450 burials had been unearthed and documented all around the area, the obligation to protect the site from further desecration necessitated a public disclosure. In their application to the court, the developers indicated that they were going to build a social housing complex on the site. The court transcript illustrates how disclosure in itself has had implications for the Ohlone First Nations people. In the efforts to protect their ancestors and the site from disturbance, Corrina Gould and other Ohlone First Nations people had to disclose information to counter information provided by the developers and the archaeological report prepared as part of the approval process. The court transcript reveals how the petitioner and applicant (the developer) sought to characterise the claims of local Ohlone First Nations people as inauthentic.

First Nation peoples in cities continue to engage in a struggle around reclaiming, belonging, and Indigenous landscape-shaping for and by First Nations peoples (Fenster 2004, 2005a, 2005b), but there is also a struggle around claiming land and place and protecting significant Indigenous sites in cities in the neoliberal age.

This chapter has illustrated how urban transformation confounds Indigenous placelessness in the contemporary moment. Indigeneity risks simply being an aesthetic commodity or becoming harnessed for cultural upgrades or branding assets in redevelopment programs in the reimagined culturally and historically vibrant neoliberal settler city layered alongside Newcastle's convict, industrial history and its festival culture as a happening place (Mayer 2017). There is an opening 
up of the city spaces for Indigenous history and places in the new post-industrial consumer city in the building of new city cultural landscapes, but these processes are complex and fraught.

They go only a little way toward actualising a right to the city and reconciliation as envisaged nearly 30 years ago.

\section{Notes}

1 Newcastle Now, www.newcastlenow.org.au/discover-tile-places/honeysuckle-promenade

2 Twenty five years after Newcastle City Council signed the Commitment to Indigenous Australians and 17 years after local Kooris petitioned council, the current Lord Mayor Nuatali Nelmes unveiled its trials of dual-name signs using Awabakal and Worimi words for landmarks. Council used Smart City technology to bring Awabakal language to life.

3 Information about the artefacts and the significance of the site to Awabakal people is contained in an interpretive sign in the Ibis hotel foyer.

4 The known destruction of Awabakal significant sites has a long history in Newcastle. In 1971, basic archaeological research conducted by LK Dyall identified knowledge about site types and site locations. At the time, Dyall observed that shell middens that had been documented in earlier references along the Hunter River had been severely impacted by industrial activity and that "prior to the establishment of heavy industry in Newcastle, shell middens extended all the way from Port Waratah to Sandgate and along the riverfront' (Dyall 1971,155). By the turn of the century, a number of those areas investigated had already been destroyed or impacted by development.

5 I also conducted keyword searches of all articles referencing 'land rights', 'land claims' and 'native title' printed in the Newcastle Herald between January 1998 and December 2002. There were 75 different references to local Indigenous land or native title claims. These included letters to the Editor, editorials and actual articles on either local Indigenous land or native title claims.

6 Darkinjung Local Aboriginal Land Council v Minister for Planning and Infrastructure \& Anor; Australian Walkabout Wildlife Park Pty Limited (ACN 115 219 791) as Trustee for the Gerald and Catherine Barnard Family Trust $\mathrm{v}$ Minister for Planning and Infrastructure \& Anor [2015] NSWLEC 1465.

7 Ruegg \& Ellsworth $\mathrm{v}$ City of Berkeley and City of Berkeley Department of Planning and Development, Superior Court of the State of California County of Alameda, Case No. RG189930003.

\section{References}

Alfred, T \& Corntassel, J (2005). 'Being Indigenous: Resurgences against Contemporary Colonialism', Government and Opposition, Vol. 40, No. 4, pp. 597-614.

Andersen, C (2005). 'Residual Tensions of Empire: Contemporary Métis Communities and the Canadian Judicial Imagination', in Reconfiguring Aboriginal State Relations. Canada: The State of the Federation, pp. 295-325.

Anderson, E (2015). 'The White Space', Sociology of Race and Ethnicity, Vol. 1, No. 1, pp. 10-21.

Archaeological and Heritage Management Solutions (2011). 'Palais Royale Final Excavation Report for SBA Architects'.

Bairstow, D (1989). 'Newcastle Lumber Yard: 1989 Excavation Report', Unpublished report for The Heritage Council of NSW and Newcastle City Council. 
Barnes, D (2015). 'Rocla's plan to expand Calga sand quarry rejected by Land and Environment Court', The Daily Telegraph, 19 November, www.dailytelegraph.com.au/ newslocal/central-coast/roclas-plan-to-expand-calga-sand-quarry-rejected-by-landand-environment-court/news-story/be26bc5b860507b928a0695575940d80, accessed 19 November 2015.

Behrendt, L (2006). 'The Urban Aboriginal Landscape', in Anderson, K, Dobson, R, Allon, F \& Neilson, B (eds.), After Sprawl: Post-suburban Sydney. E-Proceedings of the 'PostSuburban Sydney: The City in Transformation' Conference, 22-25 November 2005. Sydney: Centre for Cultural Research, University of Western Sydney, p. 1.

Brawley, S (1997). " "A Comfortable and Relaxed Past": John Howard and the "Battle of History" ', Electronic Journal of Australian and New Zealand History, published online 27 April, http://www.jcu.edu.au/aff/history/article/brawley.htm.

Carleton, S (2019). 'The Legacy of Oka in an Era of Supposed Reconciliation', The Conversation, 25 September, https://theconversation.com/the-legacy-of-oka-in-an-eraof-supposed-reconciliation-123150, accessed 26 September 2019.

Carter, P (1987). The Road to Botany Bay. London: Faber \& Faber.

CBC News (2018). 'Montreal Names Councillor in Charge of Reconciliation with Indigenous People', $C B C$ News, www.cbc.ca/news/canada/montreal/marie-josee-parentmontreal-indigenous-reconciliation-1.4792087, accessed 20 September 2020.

Coulthard, G (2014). Red Skin, White Masks: Rejecting the Colonial Politics of Recognition. Minneapolis, MN: University of Minnesota Press.

Dankinjung Local Aboriginal Land Council (2018). 'Financial Report 2018', www.acnc. gov.au/charity/79d2e678ccb84b78588798fc2d8419ed\#financials-documents, accessed 20 February 2020.

Deer, J (2017). 'Montreal Takes One Step Closer to Reconciliation', The Eastern Door, www.easterndoor.com/2017/08/28/montreal-takes-one-step-closer-to-reconciliation/, accessed 3 January 2019.

Dixon C \& Sullivan, A C (2015) 'Judgment', Darkinjung Local Aboriginal Land Council v Minister for Planning and Infrastructure \& Anor [2015] NSWLEC 1465.

Douglas, P, Tuck, D \& Steele, D on behalf of Accor Asia Pacific (2001). Accor Ibis Hotel site 700 Hunter Street Newcastle, NSW: Interim Report on Archaeological Test \& Salvage Excavations at the Site. Stanmore, NSW: Archaeological \& Heritage Management Solutions.

Dyall, L K (1971). 'Aboriginal Occupation of the Newcastle Coastline', Hunter Natural History, Vol. 3, No. 3, pp. 154-168.

Fenster, T (2004). 'Belonging, Memory and the Politics of Planning in Israel', Social \& Cultural Geography, Vol. 5, No. 3, pp. 403-417.

Fenster, T (2005a). 'Identity Issues and Local Governance: Women's Everyday Life in the City', Social Identities, Vol. 11, No. 1, pp. 21-36.

Fenster, T (2005b). 'The Right to the Gendered City: Different Formations of Belonging in Everyday Life', Journal of Gender Studies, Vol. 14, No. 3, pp. 217-231.

Foucault, M (1976). The History of Sexuality. Paris: Hachette.

Harris, C I (2003). 'Whiteness as Property', Harvard Law Review, Vol. 106, No. 8, pp. $1710-1791$.

Howard-Wagner, D (2006). Post-Indigenous Rights - The Political Rationalities and Technologies Governing Federal Indigenous Affairs in the Contemporary Period. PhD Dissertation, University of Newcastle, Newcastle.

Howard-Wagner, D (2009). 'Whiteness, Power Relations, Resistance and the Practical Recognition of Indigenous Rights in Newcastle', Theory in Action, Vol. 2, No. 1, pp. 40-65. 
Hugill, D (2017). 'Colonial and Postcolonial Cities', in Turner, B S (ed.), The WileyBlackwell Encyclopedia of Social Theory. Hoboken, NJ: Wiley Blackwell, pp. 1-3.

Janoschka, M \& Sequera, J (2016). 'Gentrification in Latin America: Addressing the Politics and Geographies of Displacement', Urban Geography, Vol. 37, No. 8, pp. $1175-1194$.

Kelly, M (2011a). 'History Junked', Newcastle Herald, 21 May 2011, p. 1.

Kelly, M (2011b). ‘6500-Year-Old Heritage Junked', Newcastle Herald, 21 May 2011, p. 7.

Kelly, M (2015). 'Awabakal Aboriginal Group Lodge Harbour Land Claim', The Newcastle Herald, 15 January, www.newcastleherald.com.au/story/2819554/awabakal-lodgesharbour-land-claim/, accessed August 2016.

Kelly, M (2019). 'Environment Minister Melissa Price Issues Declaration to Protect West Wallsend Butterfly Cave Site', The Newcastle Herald, 14 February, www. newcastleherald.com.au/story/5903335/commonwealth-protection-for-butterfly-cavesite/, accessed 20 February 2019.

Lindeman, T (2020). 'Revolution Is Alive: Canada Protests Spawn Climate and Indigenous Rights Movement', The Guardian, 28 February, www.theguardian.com/world/2020/ feb/28/canada-pipeline-protests-climate-indigenous-rights, accessed 4 July 2020.

Lipsitz, G (1995). 'The Possessive Investment in Whiteness: Racialized Social Democracy and the "White" Problem in American Studies', American Quarterly, Vol. 47, No. 3, pp. 369-387.

Mayer, M (2017). 'Whose City? From Ray Pahl's Critique of the Keynesian City to the Contestations Around Neoliberal Urbanism', in Marcuse, P, Brenner, N \& Mayer, M (eds.), Cities for People, Not for Profit: Critical Urban Theory and the Right to the City. New York: Routledge.

McLeod, T (2018). 'We Can Save the West Berkeley Shellmound', https://sacredland.org/ we-can-save-the-west-berkeley-shellmound/, accessed 10 September 2019.

McMillan, M (2017). 'Butterfly Cave Under Threat', The Newcastle Herald, 25 October, www.newcastleherald.com.au/story/5012027/butterfly-cave-threat/.

Newcastle Aboriginal Support Group (2001). Let's Get on with It: Report of the Hunter People's Inquiry into a Treaty, prepared by Newcastle Aboriginal Support Group. Broadmeadow, NSW: Newcastle Aboriginal Support Group.

Nesbitt, S (2017). En/countering the Colonial: Aiako'nikonhraién: ta'ne and You Are on A Mohawk Land. Two Case Studies on Art, Refusal and Recognition in Montréal. Doctoral Dissertation, Concordia University, Montreal.

NSW Government (2020). 'Calga Aboriginal Cultural Landscape', www.environment.nsw. gov.au/heritageapp/ViewHeritageItemDetails.aspx?ID=5064142, accessed 30 October 2019.

NSW Ombudsman (2011). 'Addressing Aboriginal Disadvantage: The Need to Do Things Differently', A Special Report to Parliament Under s 31 of the Ombudsman Act 1974, October. http://alc.org.au/media/73895/sr_aboriginal\%20disadvantage\%20report\%20oct11.pdf.

Porter, L \& Barry, J (2016). Planning for Coexistence? Recognizing Indigenous Rights Through Land-Use Planning in Canada and Australia. New York: Routledge.

Rose-Redwood, R (2016). " Reclaim, Rename, Reoccupy": Decolonising Place and the Reclaiming of PKOLS', ACME: An International E-Journal for Critical Geographies, Vol. 15, No. 1, pp. 187-206.

Sage, G (2016). 'Building Relationships and Mapping Community in the Urban Environment', in D Martinez, G Sage \& A Ono (eds.), Urban American Indians: Reclaiming Native Space. Santa Barbara: Praeger. 
Tatz, C (1995). Obstacle Race: Aborigines in Sport. Sydney: University of New South Wales Press.

Tomiak, J (2016). 'Navigating the Contradictions of the Shadow State: The Assembly of First Nations, State Funding, and Scaled of Indigenous Resistance', Studies in Political Economy: A Socialist Review, Vol. 97, No. 3, pp. 217-233.

Ville Montreal (2017). 'Reconciliation with Indigenous Peoples: Montréal Unveils Its New Coat of Arms and Its New Flag', 13 September, http://ville.montreal.qc.ca/portal/ page?_pageid $=5977,43117560 \&$ dad=portal\&_schema=PORTAL\&id=29176\&ret $=\mathrm{h}$ ttp://ville.montreal.qc.ca/pls/portal/url/page/prt_vdm_en/rep_annonces_ville/rep_communiques/communiques, accessed 20 September 2020.

Westbury, M (2015). Creating Cities. Melbourne: Niche Press. 


\section{Neoliberal poverty governance and the consequent effects for Indigenous community development in the city}

\section{Introduction: the imperceptibility that cloaks the journey}

In the 21st century, Miromaa Language and Technology Centre secured a ground floor inner-city business premise with a shopfront in the heart of Newcastle's historic business district. It established a gallery and gift shop in the shopfront of its new premises. The passer-by could choose to see Miromaa as a small Indigenous art gallery/gift shop, which sells everything from possum skin cloaks to didgeridoos that are wholly the work of First Nations artists. What remained hidden in plain sight was a highly successful community enterprise that has been instrumental in Indigenous cultural resurgence in this city, bringing Awabakal language back into place and space. Today, Miromaa occupies its own significant and prominent place in Indigenous cultural resurgence in the post-industrial city, including the renewal and revival of cultural practices and the speaking of Awabakal language within the boundaries of the traditional Awabakal nation. The CEO has mobilised Awabakal language as an apparatus for cultural resurgence in Newcastle. The revitalisation of Awabakal language is about empowering a community and reclaiming Indigenous cultural identity.

Miromaa began with a highly successful vision of 'reclaiming, finding, revitalising, and bringing back Awabakal language' (transcript, CEO Miromaa). Miromaa is a 'local Awabakal word; roughly translated [it] means saved' (transcript, CEO Miromaa). Miromaa's success sits within the context of Indigenous community building and development in the city of Newcastle. Miromaa came out of Yarnteen, which came out of the Awabakal Cooperative. Miromaa started on 'two $\$ 25,000$ grants awarded to Yarnteen through federal government grants administered through the then Aboriginal and Torres Strait Islander Commission' (transcript, CEO Miromaa). In 2002, Miromaa was formally formed as Awabakal Cultural Resource Association, moving the language program and cultural program out of Yarnteen into a newly established community organisation. It took over the two funding projects committed to cultural and language awareness across Awabakal nation. That same organisation has operated under the trading name of Miromaa Aboriginal Language and Technology Centre since 2008. It 
remains a small organisation with one full-time and three part-time staff members who are committed to cultural and language revitalisation. Business activities are a means of achieving community benefit through the reclamation of Awabakal language. Miromaa has been instrumental in conducting education in preschools, primary schools, and high schools in the region, raising awareness of the importance of Awabakal language to cultural identity. It has created Awabakal language resources.

Miromaa dedicates its work to not only recovering Awabakal language, but recovering Indigenous languages internationally. Its CEO created the Miromaa languages and education program utilised globally to conserve over 150 Indigenous languages/dialects in Australia and many more internationally. Miromaa provides support nationally and globally to First Nations peoples in the reclaiming of their language. Its contribution to society was acknowledged in a public address at the White House Tribal Youth Ambassador Awards in the United States in 2016. Jayden Lim, a Pomo Indian youth, and descendent of a group of First Nations people who barely survived colonisation of California (Lim 2016) described how a group of Pomo Newark Indian youth from Santa Rosa city in California came together with Miromaa in 2010 to create six language apps for the different Pomo language groups to assist with the resurgence and learning of Pomo language (Lim 2016).

Miromaa is one of a loose alliance of First Nations organisations that have been the apparatus for Indigenous community development in this city. Kooris mobilised Indigenous models of social relations, governance, and culture in creating institutions and activating local participation (Radcliff \& Laurie 2006, 244). This model of fore-fronting Indigenous social relations, governance, language, culture, and cultural identity in community development has been critical to overcoming Indigenous disadvantage in its full complexity. For the CEO of Miromaa, and other Koori leaders, the revitalising and strengthening of Indigenous social relations, governance, language, culture, and cultural identity is intertwined with and indivisible from overcoming Indigenous disadvantage in this city. That is, Indigenous social relations, governance, language, culture, and cultural identity are vital community resources in overcoming Indigenous disadvantage.

Like Ralph Ellison's Invisible Man, local Kooris struggle with the imperceptibility that cloaks their journey in pursuing Indigenous community development and reterritorialisation in this city (Ellison 1952). Invisibility concerns the desire to be socially seen in regards to rebuilding and reclaiming First Nations peoples' rightful place within the city. Having a voice, being heard, being seen or understood is the desired state. Seeing the institutions and governance structures created is the desired state. Recognising the social capabilities of the community to mobilise Indigenous social relations, governance, language, culture, and cultural identity to overcome the disadvantage that First Nations peoples experience is the desired state. Instead, Indigenous community development and reterritorilisation are ignored, marginalised, and made insignificant through contestation and the imposition of pervasive neoliberal rationalities governing Indigenous policy 
in the contemporary moment. The whiteness of the system, the law, the settler city, and the politicians and bureaucrats are instead continually imposed on First Nations peoples in this city. It is not only First Nations peoples' community development in the city of Newcastle that is invisible. Community development and Indigenous resurgence are invisible in other localities like Chicago, Oakland, Redfern, and Vancouver.

Invisibility plays out in many ways. It is not only the success of urban Indigenous community development that is invisible. The intrinsic value of culture and language as community resources to overcoming disadvantage are not understood. Bringing language back onto country goes beyond investing in the documenting of Awabakal language, creating resources, and educating teachers so they can teach a few words of Awabakal language in state preschools and schools. It requires bringing Awabakal language into the daily experience of Novocastrians through signage, civic events, and other public means. It requires governments investing in the capacity of Miromaa to work with the community, especially other community-based organisations, to embed Awabakal language in their programs, such as the Awabakal pre-school program and the Awabakal Medical Centre's mental health program. As the CEO of Miromaa points out, it is about investing in organisations so that they can 'use language and identity as a means of psychological healing and so forth and strengthening identity and self-esteem' (transcript, CEO Miromaa).

Organisations like Miromaa, Wandiyali, the Awabakal Cooperative, and Yarnteen remain successful organisations. Yet, policymakers and bureaucrats fail to comprehend or see the primary role that these organisations play in mobilising Indigenous social relations, governance language, culture, and cultural identity to overcome disadvantage through the specific programs that local Kooris have designed. ${ }^{1}$

Community organising and community development is the process and product of Indigenous agency in cities. Indigenous social relations, governance, language, culture, and cultural identity are at the heart of community development. This has led to empowerment, self-determination, and improved community wellbeing. It led to the development of significant social support networks. It has assisted with overcoming the complex disadvantage that First Nations peoples experience. It has seen the creation of an Indigenous social economy with the flow of economic benefits and improvements in socio-economic outcomes for First Nations peoples in this city. While there are lower levels of individual and community pathology, racism, homelessness, incarceration, and family violence, they still exist. There are bona fide community accomplishments that one can point to, and tangible improvements are in place.

Indigenous community development has become, as it will be argued, in a purposeful and critical sense wilfully invisible in policy spaces in the neoliberal age. The wilful and pernicious political and social practices that operate to render Indigenous community development invisible at the same time regulate the regimes of visibility circulating throughout the political and social body itself, 
determining what can legitimately be rendered visible, and how. Invisibility concerns the wilful ignorance of the success of Indigenous community development, the significant Indigenous social infrastructure, and even the success of Indigenous organisations in cities. That is, it is a mentality of rule that ignores a preexisting, self-determining subjectivity in which Indigenous organisations operate as social, political, and economic entities charged with progressing community development and the right to self-determination in this city.

Since 2004, the Australian government has seen successive moves to change the way it does business with First Nations organisations and social delivery more widely, which sits alongside a major policy shift in the governance of Indigenous poverty. A market-based logic has been applied to the delivery of services and programs designed to overcome disadvantage, and now First Nations organisations compete with mainstream not-for-profit organisations to deliver government commissioned social services to overcome individual disadvantage. This concerns the ways that successive Australian federal governments have seen, understood, controlled, and governed the 'Indigenous population' in the neoliberal age (Howard-Wagner 2018a). All areas of Indigenous policy have been reformed - from early childhood education to Aboriginal and Torres Strait Islander legal services, to Indigenous housing, to benefits for the long-term unemployed, to support for older adults, and First Nations peoples with disability.

The broader literature on the effects of neoliberal poverty governance on community development illustrate how the community action/participation/development elements of anti-poverty governance programs 'enrol' disadvantaged/poor communities as both subjects and objects of social policy delivery as people who are incentivised to change and act (Clarke 2010, 639; Meade 2018, 225). The literature illustrates the inherent conflicts in reconciling the competing identities of community development/poor communities, active subject/biddable object (Meade 2018,225). Mead notes that as programmes were operationalised, issues of dispute emerged between communities and policy-makers that still vex community development processes: the depth and scope of popular participation, appropriate chains of accountability and control, the respective roles and authority of the local and national state, constructions of poverty and its causes, and the relative weighting afforded to personal and structural change' (Meade 2018, 225). Poverty and community development become a technology of government in which communities are problematised, targeted, and mobilised in the name of outcomes such as empowerment, social inclusion, or labour market participation (Meade 2018, 226).

Around the turn of the 21 st century, wider changes to social welfare and social policies had already begun to impact on Indigenous social development in Newcastle.

Today, the neoliberal state governs Indigenous poverty and the economics of 'disadvantage' in ways that are limited to overcoming the individualised socioeconomic disadvantage that First Nations peoples experience. Since 2004, the 
Australian government has made successive moves to change the way it does business with Indigenous organisations and social delivery more widely, which sits alongside a major policy shift in the governance of Indigenous poverty. Australian scholars, like Patrick Sullivan (2015) and others, draw our attention to the changing rules through an analysis of the economics of social policy in the neoliberal age in which markets rather than basic rights began to forefront Indigenous policy agendas (Howard-Wagner 2006; Sullivan 2009, 2015).

This new way of seeing First Nations organisations and the various Indigenous policy and government service delivery reforms over this period have accentuated the tenuous and precarious nature of the relationship of dependency that First Nations organisations have on what Iris Marion Young calls 'the state' in the context of self-determination and state dependency (Young 1990).

A new politics of non-recognition has meant that First Nations organisations in the city of Newcastle and elsewhere face new challenges in the neoliberal age. For example, organisations like the Awabakal Cooperative, Yarnteen, Wandiyali, and Miromaa find themselves marked today, not as successful self-governing Indigenous institutions in the city, but as Indigenous social service organisations operating within the wider social service market. It is through processes and practices of governing through disadvantage that the neoliberal state has perpetuated the 'domestication' and 'assimilation' of First Nations peoples via their incorporation into the mainstream society in a way that limits their own 'practices of freedom' (Foucault 2000).

What remains hidden in plain sight is the societal function of First Nations organisation as a social and political apparatus through which much of the social processes of Indigenous resurgence and survivance have occurred (see chapters three and four).

Before moving forward with the analysis, however, it should be noted that, while this analysis is in the context of Newcastle, its implications are not limited to this city. The chapter offers a better understanding of how poverty governance functions through a market logic that effectively renders Indigenous social development, community, and ways of being in the city absent from policy solutions in the neoliberal age- policy solutions that, for example, lead to the individualisation of Indigenous poverty and the suburbanisation of First Nations poverty. The consequent effect has been a disempowering of local First Nations organisations, associative communities, and Indigenous civil society in cities. Indigenous social infrastructure has deteriorated with the mainstream marketisation of social service delivery in settler nations. In some localities, like Western Sydney, many First Nations organisations no longer exist, and other longstanding organisations remain on tenterhooks waiting nervously for the next policy iteration. First Nations organisations that remain have been co-opted in service delivery, losing their capacity to meet the local needs of the community. Communal spaces and community hubs have been lost. Community has broken down, and the Indigenous communities of association that once existed around the region no longer exist. 
The chapter examines the effect of this significant policy shift on Indigenous community development in the city of Newcastle, but also Indigenous adaptation, agility, and resilience.

\section{Overcoming Indigenous disadvantage: policy silence, omission, and absence}

Indigenous disadvantage is a complex social phenomenon as experienced by local Kooris living in this city. There have been relative socio-economic improvements in employment and education. Local Kooris frame Indigenous disadvantage as 'operate[ing] outside the usual theoretical understandings of poverty and social stratification' (Walter 2009, 5). Like Indigenous sociologist and Palawa woman Maggie Walter observes elsewhere, 'Aboriginality is at the crux' of Indigenous disadvantage in Newcastle (Walter 2009, 5). Local Koori discourses give prominence to and draw attention to the deeply racialised dimensions of Indigenous disadvantage in this city (Howard-Wagner 2019). They expose and illustrate how Indigenous disadvantage is associated with past policies of racial ordering, dispossession and trauma, and contemporary racism (Howard-Wagner 2019). Partly, this concerns a long-held proposition that socio-economic accounts of Indigenous disadvantage ignore individual and institutional racism and that multiple forms of racism are determinants of disadvantage (Hummer 1996, 110, 112). It is a proposition that challenges the Australian national (federal and state) Indigenous policy in the 21 st century.

Kooris living in Newcastle refer to the importance of kinship, language, culture, and cultural identity to overcome the deeply embedded social suffering, unresolved psychophysical and psychosocial harms of historical trauma, and cultural dislocation associated with Indigenous disadvantage. Kooris not only deal with the legacies of dispossession, alienation, racism, and discrimination, but they experience social structural injustice in the present moment. That is, the disadvantage First Nations peoples experience in the present moment is an 'enduring injustice' (Spinner-Halev 2007, 2012). It is associated with historically entrenched injustice, displacement, racialisation, and social disadvantage (Ivison, Patton, \& Sanders 2000) and exclusion from social, cultural, and political processes in the society in which First Nations peoples live. The contextualising of disadvantage in this way connects the present to temporal, spatial, and racial practices that came before. It also reveals how racialised structural disadvantage continues to impinge on individual, family, and community wellbeing (Evans-Campbell 2008; Walls \& Whitbeck 2012a, 2012b). Local Kooris also interpret their disadvantage in relation to the state and the society in which they live. Historical racialised projects resulted in fractured kinship, language, culture, and cultural identity, which has had a devastating impact on First Nations peoples. Local Kooris thus explain Indigenous disadvantage in Newcastle as a highly racialised social phenomenon. They associate it with racialised exclusion (Goldberg 1993), as opposed to the effects of social externalities, such as standard indicators of poverty, place effects, 
or postcodes (zip codes) (Hunter 2007; Price-Robertson 2011, 2). Local Kooris draw attention to what sociologist Joe Feagin refers to as the distinctive social worlds that have been created by racialised oppression since colonisation (Feagin 2006, 2).

Local Kooris experience disadvantage as a community or collective social phenomenon that stems from historical racialised relations and racialised projects. Indigenous philosophies situate individual wellbeing as invariably connected to, and interdependent with, community wellbeing. Indigenous community building and development in this city has been directed at addressing this community disadvantage. Community development has targeted the effects of historical racialised social projects and the constellation of racialised disadvantage experienced by First Nations peoples. Overcoming the silence of generational disadvantage associated with racialised social projects and relations has been a critical objective of community development in this city. For example, a principal aim of Koori leaders has been to heal the fractures in culture through mobilising kinship, language, culture, and cultural identity to build community and develop community social infrastructure. Indigenous community development is aimed at alleviating the constellation of racialised disadvantage experienced by First Nations people that is an artefact and legacy of Australia's settler-colonial history and the institutionalised structuring of Indigenous/settler social relations in Australia over 200 years (Howard-Wagner 2018a, 1338).

Indigenous organisation building in Newcastle was not economically driven, but instead served a societal function. It was about Indigenous control, autonomy, and self-determination. Yarnteen's vision, for example, was to become a 'full free agent in our own development' (Jonas 1991, 12). Organisation building offered a mechanism for achieving a separate Indigenous domain. It offered a way of circumventing mainstream social, educational, employment, housing and health services, building Aboriginal social infrastructure, providing culturally centred programs and services, and 'doing business the Aboriginal way' (interview 53). It was also a means for revitalising culture, knowledge, and language, as well as improving the wellbeing of local First Nations peoples. Local Kooris created 'a really good base here ... a social base within our community. There are some very big, dominant, longstanding organisations that the community respond to and have very significant cultural processes' (transcript 58).

Indigenous community development in the city of Newcastle has achieved many enviable successes. It has improved employment and education outcomes among local Kooris. As one local Koori points out, "statistically speaking the "Aboriginal and Torres Strait Islander population" in the Newcastle Local Government Area sits at the "top of the bottom socio-economic pile" (transcript 58). The Australian Bureau of Statistics (ABS) Census data from 2001 to 2011 confirmed the assertion. In 2001, unemployment rates were over 25 per cent higher than both the state and national averages (NSW: 23.1 per cent; Australia: 20.0 per cent) (ABS Census 2001, 2006, 2011, 2016). By 2011 this unemployment rate had dramatically decreased, halving to 13.4 per cent, a figure below the state and national averages 
(NSW: 16.9 per cent; Australia: 17.1 per cent). Importantly, between 2001 and 2011, unemployment rates for Aboriginal and/or Torres Strait Islander peoples in Newcastle not only declined but declined faster than that of the general population. Therefore, the gaps between unemployment rates between First Nations peoples and general population also decreased. Despite Newcastle transitioning from an industrial to post-industrial city, although it has a mixed economy relying on its position as a regional service centre, the Australian mining boom buffered its economy. Again, the ABS census 2016 recorded unemployment rates as slightly higher for Aboriginal and/or Torres Strait Islander people in Newcastle (15.3 per cent) and the general population ( 7.4 per cent). It was lower than the national unemployment rate for Aboriginal and/or Torres Strait Islander peoples ( 18.3 per cent), but higher than the national ( 6.9 per cent) and state (6.3 per cent) rates for the general population. The end of the mining boom may account for the recent creep in unemployment rates in both the Aboriginal and Torres Strait Islander and wider population in Newcastle.

According to data from the first three Australian Bureau of Statistics census periods in the 21 st century $(2001,2006$, and 2011), the 'Indigenous population' in Newcastle has fared better than the overall 'Indigenous population' of NSW, more generally, in comparison to 23 urban NSW localities with populations of 2,000 or more. It also fares better than the national 'Indigenous population' across a range of indicators. The Newcastle 'Indigenous population' has the second-lowest unemployment rate in 2011 at 13.4 per cent, and the second smallest gap (10 per cent) in unemployment rates between Indigenous (13.4 per cent) and non-Indigenous populations ( 3.4 per cent) compared with the other 23 urban localities. First Nations people in this city receive the second-highest median personal income at AU\$411 per week. They have the second-highest median household income at AU $\$ 1,044$ per week. They have the third-highest rate of year 12 completions at 31.6 per cent. It also has the second-highest rate of tertiary (university or other) completion at 13.7 per cent. Newcastle stands out as a locality that is successfully reducing Indigenous unemployment and additionally closing the unemployment and education gap between First Nation peoples and the wider population.

Relative improvements in urban Aboriginal and/or Torres Strait Islander education and employment outcomes in Newcastle, however, only tell part of the story. For example, while individuals are 'doing okay' (transcript 66), local Kooris consider the gap in terms of the community as a whole, which is struggling, thereby mitigating an individualised socio-economic success narrative.

Contemporaneous understanding of Indigenous disadvantage is a policy approach that ignores different social histories and different social locations and past and present effects of racial and discriminatory treatment (HowardWagner 2018a, 1334). Today, policymakers and bureaucrats wilfully ignore the Indigenous philosophies that forefront social practices. Indigenous worldviews provided the structure for an epistemic, social system in which First Nations peoples assert their ways of being. Indigenous values were operationalised as 
social and political apparatuses to better the collective wellbeing of their new communities of association. Policymakers and bureaucrats wilfully ignore the Indigenous values that provide the societal rules of engagement for co-operating and building communities of association. They wilfully ignore the Indigenous philosophies that define the rules of engagement for building institutions and social infrastructure to meet the collective needs of First Nations peoples in this city. They wilfully ignore how kinship, language, culture, and cultural identity remain paramount to the functioning of urban First Nations organisations. Indigenous disadvantage has instead been interpreted as a social product of contemporary socio-economic inequality. It is situated within a political economy of poverty (Howard-Wagner 2019; Walter 2009; Walter \& Saggers 2007). Silence occurs not only through the absence of considerations of past racialised projects and relations and structural violence. It is also the tendency to ignore past racialised projects and relations and structural violence as a problem in favour of more obvious contemporaneous socio-economic indicators as explanations for Indigenous disadvantage.

\section{'Practical reconciliation', Closing the Gap, and overcoming Indigenous socio-economic disadvantage}

My government is steadfast in its commitment to the process of reconciliation between [I]ndigenous Australians and the wider Australian community. We want higher living standards and greater economic independence for Aboriginal and Torres Strait Islander people. We will work with states and territories and with ATSIC to achieve practical outcomes designed to overcome the undoubted social and economic disadvantage of our [I]ndigenous people.

(Howard 1996, 8218)

Neoliberalism has taken many twists and turns in Australia, and arguably the neoliberal age was upon Australia well before the election of the federal Howard Coalition government. Increasingly, the federal government, under the leadership of Prime Minister Hawke followed by Prime Minister Keating, began to adopt neoliberal solutions to address Australia's economic problems, and although mostly an economic project, some social policies changed, such as the abandonment of full employment policies (Karumaratnes \& Tisdell 1998).

Neoliberalism as a social and racial project became clearly evident under the leadership of the former federal Howard Coalition government. The federal government, through the intervention of then Prime Minister John Howard, reformed welfare state processes and reframed social policy. While an enduring feature of social policy discourses in Australia under Howard, for example, was the prominence given to the interpreted 'failure' of social welfarism, particularly its 
failure in relation to Indigenous Australians, then Prime Minister John Howard asserted in an interview on national television that the: 'pendulum has swung too far in favour of Aboriginal people' (Howard 1997a cited in Howard-Wagner 2006, 2008, 2018a). Indigenous affairs became a conflictual neoliberal arena in which the then Prime Minister alleged that no one group should have separate 'rights' (Howard 1997b). Howard wound back the special measures in Australian law and policy aimed at addressing past injustices and granting Aboriginal and Torres Strait Islander peoples separate Indigenous rights (Howard-Wagner 2008). While the winding back of Indigenous rights in Australian law happened fairly swiftly, changes to Indigenous policy, programmes, and services came more slowly (Howard-Wagner 2008).

In 1996, the focus shifted to 'practical reconciliation', or those practical and effective measures that address the legacy of profound economic and social disadvantage and close the socio-economic gap between Indigenous and nonIndigenous Australians to overcome Indigenous disadvantage. The federal government began to restrict its Indigenous policy approach to measures that fell within its 'practical reconciliation' approach. It left significant issues of 'unfinished business in abeyance' (Jonas 2003, 54).

Australia's Indigenous policy approach now began to align with the global focus on poverty reduction, good governance, and new social service delivery markets in the neoliberal age. Neoliberal conceptions of market competition, good governance, and a new social service delivery market now dominated government development and poverty reduction programs in Australia. While partnership and agreement-making were part of government discourses, the focus was on Shared Responsibility Agreements that delivered essential services in remote localities. Australia's Indigenous policy agenda of Overcoming Indigenous Disadvantage foreshadowed a shift in the liberal project that underpinned Indigenous development as self-determination and autonomy from the 1970s to the 21 st century.

This policy lens sees individual Indigenous socio-economic disadvantage as a phenomenon in its own right. The solution is essentially a large-scale anti-poverty program. The solution operates within a redistributive paradigm that prescribes to an 'atomic individualist ontology' (Mills 2015, 84), which addresses disadvantage through an individualistic framework of individual rights - the rights to a job, education, and housing - and targets individual agency (Howard-Wagner 2018a, 1339). That is, it offers the individual Indigenous citizen, as the beneficiary of redistribution, the opportunity to become part of the mainstream economy (Howard-Wagner 2018a, 1340). It constructs the individual 'Indigenous citizen' solely as a player in a free enterprise economy, reducing her/him to a participant in a transactional world. It is a world in which First Nations people have little power - conceiving the individual as a free agent whose primary responsibility is to herself/himself - and no-one else significantly impacts on understandings of the philosophy of the communal and community in Indigenous practices. It is also an assimilatory policy premised on the notion that Indigenous disadvantage will 
be eliminated once material inequality is overcome and the conditions that produce socio-economic inequality among individual Indigenous citizens are eliminated (Maciel \& Vine 2012, 7). So, like poverty governance in the United States, Indigenous poverty governance in Australia ignores the radically disparate impact of past history of racially differentiated and discriminatory treatment (HowardWagner 2017; Mills 2015, 84). It dissociates Indigenous disadvantage from an understanding of past policies of racial ordering, dispossession, and trauma and contemporary forms of racism (Bodkin-Andrews \& Carlson 2016, 784; HowardWagner 2009, 41).

This individualisation of the system has its effects at several levels, breaking down the relational aspects of the system created locally, promoting individual Indigenous freedom to overcome one's individual disadvantage by increasing skills and independence to participate in society, and reducing what were community-based organisations to individual service providers. This policy approach renders invisible the complex Indigenous disadvantage that First Nations peoples experience. It also ignores how socio-economic disadvantage is improved via cultural contexts, social structures, accentuated relationality, and Indigenous political processes.

It sat alongside a neoliberal policy approach that involved the marketisation of individualised social service delivery, as well as wider reforms to Indigenous policy in the neoliberal age. It is an era marked by austerity, conditionality, and expansive welfare reforms. In Australia, Canada, Aotearoa New Zealand, and the United States, a key marker is the restructuring of welfare and social services achieved through new public management reform and market managerialism.

\section{Contextualising the Australian policy of overcoming Indigenous disadvantage}

In the 21st century, the Australian state has largely sought to erase those limited Indigenous domains of autonomous power that were (re)constructed to accommodate post-settler-colonial relations (Howard-Wagner 2006, 2015, 2018a). Howard's guiding principles of 'accountability', 'improving outcomes in key areas', 'practical reconciliation', and 'promoting economic independence' (Gardiner-Garden 1999, 23) became the driving force for changes in Indigenous affairs and federal policies, programmes, and practices and funding of services for Aboriginal and Torres Strait Islander peoples (Howard-Wagner 2018a). Political discourses have discursively constructed decolonising institutions of Indigenous autonomy as 'failed experiments' (Howard-Wagner, 2008, 2010a, 2010b). Carefully calculated tactics such as audits, competitive tendering, and outcome-based performance indicators worked to problematise the management of incorporated Aboriginal and Torres Strait Islander organisations, Aboriginal legal services, and ATSIC, which were subject to widespread political accusations of Aboriginal nepotism, corruption, and poor governance arrangements (Howard-Wagner 
2006). Significant reforms to the structure and delivery of Aboriginal and Torres Strait Islander services were foreshadowed. Australia did not see a decentralisation or a minimisation of government, but a highly interventionist approach to Indigenous affairs through reforms to the provision of services and programmes to Indigenous communities. Federal Indigenous laws, institutions, and programs (such as Native Title legislation, the former Aboriginal and Torres Strait Islander Commission, Reconciliation, and Indigenous service delivery in education, housing, and health) were heavily scrutinised and restructured in the first two terms of the Howard government (1996-2001) (Howard-Wagner 2006). Urban First Nations peoples were perniciously constructed as living in a culture of poverty, a logic that imputes First Nations people as not only welfare-dependent but also pathologises poverty. Consecutive Prime Ministers have also continuously differentiated between the authenticities of remote First Nations peoples compared to urban First Nations peoples - suggesting urban First Nations peoples lack culture (Abbott 2015). The organisations that First Nations peoples created in the era of self-determination have been problematised as 'gravy trains', 'inefficient', 'lacking accountability', and 'receiving generous government funding' (Pyne 2003a, 2003b; Pyne cited in Shaw 2003).

While a key group of local Kooris started First Nations organisations in the city of Newcastle, and they and their families are associated with First Nations organisations locally, they have (contra, Vanstone 2004) historically been a model of accountability, transparency, and equity (Smith 2008, 206). Nor have select local Koori families employed by these organisations been the only ones to have access to the Indigenous social infrastructure, programs, and services they provide. Despite their dependency on government funding and its coercive effects in other contexts, community-based First Nations organisations in Newcastle maintained their creativeness and innovation from the 1970 s through to the early 21 st century.

The Australian government's rapid-fire criticisms of welfare dependency and the failed experiments of self-determination produced a lasting rhetoric that has been equated with neoliberal policy language that has smoothed the way for the imposition of a particular set of reforms to legislation and policy in relation to Indigenous corporations, Indigenous disadvantage, Indigenous service delivery, and Indigenous political representation.

Political discourses served the purpose of justifying punitive and paternalistic policies designed to shape the behaviour of First Nations peoples and the organisations that they had created, coercing them to conform to a particular way of doing business and providing programs and services aimed at overcoming dependency. Government policy and practices endeavoured to contain and remap the distinct role that First Nations organisations play in society, hindering their capacity to engage in community development and reducing them to an Indigenous service delivery function in a new social service market in this era. Indigenous organisations, which formerly operated like community cooperatives and had a far more societal function in relation to community development and self-determination, were to now operate in a competitive social service market, 
competing with mainstream not-for-profits, and each other, for funding - a market that is nonetheless false and does not attribute a true economic, social, or public value to the social service that is provided. What endures from the era of Indigenous community development in cities is local institutions in the form of First Nations organisations (Moran 2016).

This resulted in a significant shift in the way governments did business with First Nations organisations (Howard-Wagner 2018b). One year earlier, the Australian government had tried to mainstream Aboriginal legal services, which had been created in the early 1970s, putting this service out to tender among corporate law firms. One month later, the Aboriginal and Torres Strait Islander Commission (ATSIC) was abolished. Four months later, the Australian federal government of the day introduced the Corporations (Aboriginal and Torres Strait Islander) Bill 2005 into federal Parliament. The bill was to replace the Aboriginal Councils and Associations Act 1976 (Cwth). The new mainstreaming and the new Indigenous Corporations Act were designed to fix alleged problems of accountability and governance within incorporated First Nations organisations (Vanstone 2004). That is, reforms were touted as necessary in terms of addressing the 'deficits' in First Nations organisations, which were constructed in political discourses as weak governance zones (Clothier 2006, 1) and as lacking accountability (Howard-Wagner 2006). Around this time too, the Commonwealth Development Employment Program (CDEP) was abolished in urban areas, which had aimed to provide work and on-the-job training, and develop the culture and economies of Indigenous communities' (Hudson 2015, vii). First Nations organisations were progressively affected too by the further marketisation of a newly defined social service sector. Aboriginal organisations were no longer to be subsidised by the state. They were no longer to be given special treatment. This placed many existing urban First Nations organisations in funding competition with secular and religious non-government organisations. They were also subject to a whole new set of regulatory arrangements that dictated the way this newly defined social service sector did business with the government. As Sanders notes, the new mainstreaming at a government department level has seen very different Indigenous-specific programs inherited from ATSIC turned into much more standardised versions of general government programs (Sanders 2014). This new mainstreaming has also entailed the standardisation of Indigenous-specific programs into one-size-fitsall programs and the standardisation of Indigenous service delivery, so much so that specialised First Nations organisations become redundant and what becomes important is value for money. This is where mainstreaming meets a market rationality. The new mainstreaming differs in that it is not about mainstream services operating alongside Aboriginal services, as a form of complementary service delivery, which was the case in the ATSIC years. But the new mainstreaming is an apparatus or a technology of neoliberal governance. Further reforms were to come in the state of NSW, diminishing the capacity of many First Nations organisations. This would ultimately be followed by a new federal Indigenous affairs funding scheme in 2014 known as the Indigenous Advancement Strategy 
(IAS), which would see 65 per cent of federal funding for Aboriginal and Torres Strait Islander service delivery go to large, mainstream, not-for-profit organisations and the commercial sector, and only 21 per cent go to community-based First Nations organisations. While in principle the IAS enables First Nations organisations to apply for grants for community need-based programs, it has proven problematic not only in this context but nationally. These further reforms saw some urban community-based First Nations organisations around Australia go into administration. Others stopped operating (e.g. the Hunter Aboriginal Children's Service) and their services were mainstreamed (e.g. the Aboriginal Medical Centre in Western Sydney). Others started to change the way they did business in order to diminish the new stranglehold governments had on them and to reclaim their autonomy and independence and capacity to continue on with their social and cultural development agendas.

Mainstreaming can be understood in the context of its rationale, which contends that overcoming individual Indigenous disadvantage through social and health service delivery could be easily met by mainstream not-for-profits or the corporate sector. It is the idea that you can create effective, efficient, and betterquality social service delivery through competitive contracts (Howard-Wagner 2016, 2018a; Howlett, Kekez, \& Poocharoen 2017). It is an example of what Mitchell Dean describes as governments creating markets where markets did not formerly exist (Dean 2004, 161).

While not unique to First Nations organisations or not-for-profit organisations in Australia (Howard-Wagner 2006; Sullivan 2009, 2015), the insidious racialised effects and how this new regime undermines the rights of First Nations peoples is disturbing (Howard-Wagner 2006, 2009, 2017). This era has 'resulted in a hostile policy environment that left community development isolated and financially unsupported' in not only Australia but also Aotearoa New Zealand, Canada, and the United States (Aimers \& Walker 2016, 3). The solutions themselves, particularly with endeavours to change the way government social- and health-service provider organisations did business in this market, were legalistic and bureaucratic, forcing incorporated First Nations organisations to perform more like, and compete with, white western not-for-profit organisations. Arguably, one of the aims has been to assimilate First Nations organisations into the mainstream.

It is unsurprising, as this era has been recorded internationally as one in which there is an obvious policy devaluing community and not-for-profit organisations generally. Scholars have widely illustrated the negative civil society effects of marketisation of social services and the new contractualism (Salamon 1999, 2014; Williams, Cloke, \& Thomas 2012). These include, but are not limited to, undermining the role that non-for-profit organisations play in civil society, discouraging advocacy, devaluing democratic citizenship and democratic ideals such as fairness and justice, eliminating distinct specialised services, diminishing social capital, and disempowering citizens (Eikenberry \& 
Kluver 2004). So, despite social services being decentralised and delivered by community and not-for-profit organisations, they have become merely a social service delivery sector, and there is little to no participation of this sector, citizens, and communities in the design of social services (Howlett, Kekez, \& Poocharoen 2017).

The consequent sociological effect is that its modalities have reduced the function of First Nations organisations to social- and health-service delivery organisations. First Nations organisations, which formerly operated like community cooperatives and had a far more societal function in relation to community development and self-determination, now operate in a competitive social service market, competing with mainstream not-for-profits, and each other, for funding - a market that is nonetheless false and does not attribute a true economic, social, or public value to the social and/or health service that is provided.

\section{The invisible hand of Indigenous policy and Indigenous social economies in cities}

What's happened in the last ten years is we lost ATSIC, CDEP as well.

(transcript 53)

I know when they did mainstream, the Aboriginal programs and asked for tenders across the community that diluted ownership of our own programs. I think we've got to be letting Aboriginal people have that, I guess, place where they're able to bring the services to their own people and not dilute it across a whole range of different service providers who may not have the connection to community or the real understanding of the needs. So, it's really important that Aboriginal community-based organisations have those programs.

(transcript 50)

Mainstream services don't give you a cultural program that you need. It doesn't give you an environment where you feel culturally safe.

(CEO Aboriginal Organisation 12)

The difference between mainstream and Aboriginal services [is] the way that it's provided. We're part of the community.

(transcript 60)

The problem with the current funding arrangements with government is they're so restrictive, the funding agreements, they don't allow innovation. They don't 
allow entrepreneurship, okay? They want the innovation and entrepreneurship but they're not exactly allowing it to be flexible enough to achieve that. They're stifling entrepreneurship and innovation.

(transcript 56)

Everybody in this office has gone to leadership and governance training, some of it Indigenous-run which has been absolutely great. Some of its government stuff. You learn from your Elders. There have been unreal Indigenous leadership programs where you have Elders come in and talk to you about your leadership style is - and you get together in groups of up to 40. You work through the different things in your community. That's leadership. Going to a community service-funded leadership course where you've got a piece of paper and a pen that tells you to be a good leader you have to have these qualities. That, to me, is not leadership. I think we need governance. I think we do need leadership. ... Not only is it not allowing that, it's also devaluing the skills, the knowledge and the people within an area.

(transcript 55)

Local Kooris describe in detail how this neoliberal regulatory regime unnecessarily governs the way they do business, as well as how policies and funding arrangements constrain their capacity to act autonomously in meeting the needs of local First Nations peoples as defined by First Nations peoples. They describe the courses senior position holders are sent on to ensure they engage in 'good governance' practices, manage risk, and improve standards and efficiency. They explain the processes their organisations have to go through to meet new forms of accreditation required to deliver housing, child wellbeing, and family services, for example. Those sent to mandatory governance training as part of their contractual arrangements accepted that this was part of the way 'governments now do business' (transcript 66). Nevertheless, they note that governments often failed to recognise the importance of Indigenous culture and obligations to community as central to the governance and success of local First Nations organisations. Many also commented to the effect that 'good [Aboriginal] governance is also being inclusive of community and being ensuring service provision to the community ... that shared vision' (transcript 55). Many noted how this, coupled with the demands of new contractual and funding arrangements, is changing and limiting the way First Nations organisations operate. It is 'hindering the capacity for innovation and entrepreneurship' (transcript 56). Their accounts detail the effects of the marketisation of social services. They reveal too how new contractualism, paternalism, and conditionality impact on their capacity to 'do business the Aboriginal way' (transcript 53). It also 'limits the time we have for collaborating with other organisations' (transcript 61). It is 'stopping our momentum in addressing Aboriginal disadvantage' (transcript 58).

The focus of organisations has been redirected away from the pursuit of community control over overcoming First Peoples' disadvantage and improving wellbeing 
toward an apolitical pursuit of service delivery aimed at addressing individualised socio-economic disadvantage. It has changed the way First Nations organisations do business and the roles of senior managers within these organisations. CEOs, for example, describe themselves as functioning like business managers rather than community advocates and agents of community development, "chasing the resources and doing the paperwork, which doesn't leave time for the important stuff [like community engagement, advocacy, and development]' (transcript 58). What is more, another interviewee notes, First Nations organisations now struggle to reconcile the demands of their community memberships (what local First Nations people need) with the agendas imposed on the Indigenous service delivery frameworks (what services governments think First Nations people need) (transcript 57).

Organisations not only struggle to find funding to develop programs to address local community disadvantage but also the widely held perception that they are no longer community-focused. Despite this, local Koori remain active in the community's economic and social life.

\section{Urban Indigenous governance and organisational governance}

Local Kooris have developed new ways for the community and service providers to work together in the interest of First Nations peoples, including working together to improve First Nations peoples' connection to the range of support services available. Newcastle has become a regional centre that now hosts a number of state and federal government departments, including a regional office of New South Wales Aboriginal Affairs and the federal Department of Social Services (formerly the federal Department of Department of Families, Community Services, and Indigenous Affairs). What operates now is a form of urban Indigenous governance around social service delivery. This model extends beyond the function of organisations established by First Nations peoples in cities to include state and non-state actors. It has the effect of watering down the local approach to Indigenous governance and the intent of Indigenous governance through the process of organisation building.

A lot of Kooris work in government agencies in either identified positions or in non-identified positions, where they can support and help community. That's what people want to do around here. They want to be a part of building on what's been started, and supporting community.

(transcript 3)

We do have an extensive network. We're forever getting emails about what's going on within our communities and emails about what's going on. So, we do have a really, really big extensive network of Aboriginal based, 
government and non-government that work together and hence the actual Newcastle Aboriginal intergovernmental meeting. That's where you've got departmental and non-governmental people coming together and just advising what's going on within the communities. It's good for us; they'll let us know what's going on and then we pass it on to other people and sort of let them know what's going on.

(transcript 29)

There are strong social networks between Kooris working in First Nations organisations, mainstream not-for-profit organisations, and local, state, and federal government departments and intergovernmental networks working together to address homelessness and justice.

There is a distinction between urban Indigenous governance around delivering social services to disadvantaged individuals and self-government around overcoming disadvantage in this city. There are clear benefits associated with collaboration, social capital, and networking in terms of addressing a particular social problem, such as homelessness through an intergovernmental committee or social service providers working together to address the complex needs of an individual Koori who finds herself/himself homeless, her/his child(ren) removed, unemployed, and in contact with the justice system. However, working together in this way is not Indigenous self-governance in practice. It is not aimed at overcoming Indigenous disadvantage as a community experience. It does not build community. It does not develop social infrastructure to address disadvantage as a complex social phenomenon. It assists the individual to address her/his disadvantage.

\section{Surviving neoliberal bureaucratisation: Indigenous adaptation and resilience versus resistance}

Pernicious invisibility concerns how this model of doing business draws First Nations peoples back into a historically racialised cycle of adaptation to change and resistance to oppressive forces. That is, First Nations organisations are navigating yet another invasive system that attempts to colonise the Indigenous domain. It can be said too that the regulatory technologies of neoliberal governance have weakened Indigenous autonomy and self-determination. For example, changes to funding arrangements severely restrict the means for financing their autonomous functions, reducing the capacity of First Nations organisations to meet the local needs of First Nations people.

Similar to what Dodd and Penehira, Green, Smith, and Aspin et al. observe elsewhere, local Kooris are forced to accept, conform to, adapt to, and overcome individualised Indigenous socio-economic disadvantage and participating in a social service market that delivers services and programs to First Nations peoples at the expense of Indigenous community development (Dodd 2002; Penehira, Green, Smith, \& Aspin 2014, 97). Indigenous adaptation and resilience 
is required in order to maintain survival. As Thomas, Mitchell, and Arseneau, point out, a pre-disposition to frame Indigenous resilience in the context of the capacity to succeed despite adversity is problematic in the context of wellestablished literature on colonial, collective, and intergenerational trauma (Thomas, Mitchell, \& Arseneau 2016, 116).

First Nations organisations in this city are resilient and adept at adapting to the change in the way that governments do business with them. Importantly though, the onus is on First Nations organisations to bounce back or go out of business. The problem, as Penehira, Green, Smith, and Aspin (2014) point out, is the framing of First Nations peoples as resilient (Penehira, Green, Smith, \& Aspin 2014). It puts the onus onto First Nations peoples to bounce back and buy into the idea that it is First Nations peoples who have to adapt and to simply get better at bouncing back and being resilient (Penehira, Green, Smith, \& Aspin 2014, 96). It requires First Nations peoples to accept their position as disadvantaged and dispossessed peoples (Penehira, Green, Smith, \& Aspin 2014, 97). Indigenous adaptation and resilience needs to be seen as a historical, racialised cycle. It is what led to Indigenous resistance and community development in this city. Resistance has been central to overcoming the disadvantage that First Nations peoples experience and to improving wellbeing (Penehira, Green, Smith, \& Aspin 2014, 102). Indigenous autonomy and self-determination in this city emerged from agility, adaptation, and resilience. Indigenous community development as resistance represented 'an approach of collective fight-back' (Penehira, Green, Smith, \& Aspin 2014, 96). So, it is important to situate resilience historically and in the context of histories of colonisation, racialised projects, and oppression, which have 'demanded a resilient response in order to maintain survival' (Penehira, Green, Smith, \& Aspin 2014, 97).

Take, for example, Wandiyali and how it has adapted as an individual organisation (Howard-Wagner 2015). While the general manager previously developed a number of successful, innovative parenting programs, including Burri (a parenting program for young homeless pregnant Koori women), today it primarily delivers government-developed programs. Wandiyali remains a highly successful organisation that is resilient and adaptive (Howard-Wagner 2015). In 2007, it was so successful at delivering government programs that it got its break into larger services with the 'Brighter Futures - Early Intervention' program (Wandiyali 2020). The Brighter Futures program is mainstream early intervention program designed to help families with children who are at high risk of entering or escalating within the child protection system. In 2013, it successfully saw rapid growth with the organisation gaining interim-accreditation as an Out of Home Care Children's Services Agency (Wandiyali 2020). In 2018, it managed to purchase premises at Boolaroo. Today, Wandiyali provides a wide range of services to cater to all levels of the Aboriginal and Torres Strait Islander community in the Newcastle, Lake Macquarie, Hunter, and Port Stephens regions (Wandiyali 2020). It now has over 60 employees and continues to grow, achieve, and strengthen (Wandiyali 2020). 
First and foremost, Wandiyali operates to benefit the community and works hard to keep culture and community strong. It continues to make many contributions in this regard.

Understanding Indigenous forms of agency and resistance as a collective practice embedded in Indigenous practices is useful for understanding how First Nations peoples work to modify the technologies of neoliberal governance to ensure that Indigenous practices are not subverted (Howard-Wagner 2015). That is, while governments attempt to impose a new Indigenous neoliberal subjectivity onto organisations and First Nations peoples who access services, cultivating a new Indigenous subjectivity - one in which the Indigenous subject is individuated and incorporated into the nation - organisations resist this subjectivity, attempting to equip First Nations peoples with the tools and strategies for overcoming the disadvantage that they experience through connecting First Nations peoples to a subjectivity grounded in Indigenous practices.

\section{Revaluing and shifting the relationship of funding dependency}

So, while all grasp the rules of the neoliberal game and adapt, and have become highly professional business-like entities, it is not about adapting to the new rules of the game. It is about finding strategies to respond to this invasive system, which attempts to colonise the Indigenous domain, as well as to its racialised effects and its undermining of Indigenous rights (Howard-Wagner 2006, 2016, 2018a). It is important to acknowledge the critical sites of agency and resistance that come from such responses - for example, how the reactions and strategies of those who manage First Nations organisations evidence the critical or reflexive vigilance of Indigenous agency and resistance in the neoliberal age (HowardWagner 2006, 2016).

Indigenous agency and resistance are expressed as endeavours to pursue innovative funding solutions that will change the funding dynamic with the state, subsidise organisational initiatives, or lead to funding self-sufficiency - strategies adopted creatively to bring about autonomy and self-determination in overcoming the community disadvantage that local Kooris experience and improving collective wellbeing. The onus is on First Nations organisations to be resilient, adapt, and find solutions.

What is an obvious impediment to agency and resistance in the city is that First Nations organisations remain in a relationship of dependency with the state (governments) in terms of not only funding, but also mainstream political recognition. Indigenous community development occurred in an era when there were government funds available for policy innovation in which they developed novel methods to address social issues and community disadvantage. They convinced government funders to support these initiatives, usually by presenting their solutions as more effective and less expensive than existing programs. Today, it is almost impossible to develop local solutions to local problems. 
Agency and resistance are not directed toward individually set, predominately economic goals, but at reinvigorating much of what is currently undermined in this era. CEOs and boards of First Nations organisations are looking for novel and positive ways to continue the work they have been doing. Many see this pathway as occurring through economic endeavours that generate cash flow so that they are less dependent on government funding. For example, '[E]conomic development . . . will allow us to do what we want to do culturally and do what we want to do socially' (transcript 66). The pursuit of economic endeavours to create cash flow is a means to a social and cultural end. However, there is no community ownership of land. While a compensatory system, the capacity for land rights is vested with the Awabakal Local Aboriginal Land Council, (see chapter 6). That organisation alone benefits financially from land rights.

Local Kooris no longer talk about self-determination in terms of autonomous self-governing entities, but they frame self-determination as economic independence. This is reflected in the extract from an interview with one local Koori leader who stated that 'self-determination is about being financially sustainable and viable' (transcript 61) and 'economic development is just a means to an end . . that will allow us to do what we want to do culturally, and do what we want to do socially' (transcript 66). For organisations like Yarnteen Ltd and Awabakal Cooperative, this is not about creating social and economic enterprises or acquiring assets, as that has been very much a part of their business operations for decades, but about moving toward greater self-sufficiency (Awabakal Strategic Plan 2017-2020). Awabakal Cooperative is no longer a cooperative. In 2014, it became Awabakal Limited and registered as a not-for-profit public company limited by guarantee (Awabakal Strategic Plan 2017-2020). It has a new constitution, and its principal purposes have broadened to reflect its new economic development agenda, which sits alongside its original objectives to provide services to First Nations people in the Newcastle area as well as to strengthen and foster the development of First Nations identity and culture in the Newcastle area (Section 6, Awabakal Ltd Constitution).

The Community Development Employment Projects (CDEP) scheme was hugely successful in Newcastle. It facilitated Indigenous economic and community development in this city. However, it was administered by one community-based organisation, and that community-based organisation alone benefitted from the scheme. That organisation is now in a far better position than other organisations because it has business enterprises and assets acquired under the CDEP scheme.

Landholdings and associated resources too could facilitate Indigenous economic and community development in this city. However, the way that the Aboriginal Land Rights Act is structured means that local Aboriginal Land Councils can only make claims over vacant crown land. There is no scope for economic royalties or economic compensation from the destruction of Indigenous land and sites and, while a membership-based organisation, a single local Aboriginal Land Council holds all the land, assets, and income from the acquisition of local vacant crown land. 
This does not mean that a space has opened up for Indigenous economic development, but rather Indigenous organisations in this city are endeavouring to build their capacity or create this space because they have the capacity to do so. To varying degrees, First Nations people in the greater region of Newcastle have long been engaged in developing new external partnerships and associations and/or flexible and innovative entrepreneurial solutions, such as social enterprise, assetbuilding, and Indigenous-driven economic development. Importantly though, this is not neoliberal co-option, but what McCormack describes in relation to a different context as a reaction to Indigenous dispossession occurring in the market (McCormack 2018). It is a means that Williams discusses elsewhere of turning away from institutionalised power hierarchies and a means of shaping their own social orders (Williams 2014, 10). So, while Yarnteen and Awabakal already have soundly managed income-generating assets and/or social enterprises and subsidise social programs through income generated from these assets and enterprises, they are far from achieving funding sustainability. They face the challenge of getting 'governments to see some value in what you do' (transcript 60) or 'moving away from a government-funded model to a purchasing model and insisting that the government is then purchasing these services off you' (transcript CEO Awabakal).

While medical services and childcare services can potentially generate a sliding scale fee for the provider, the fee charged depends on the capacity of the user. Awabakal Medical Service bulks bills (Awabakal Medical Service 2020). However, there are First Nations organisations that will remain dependent on government funding because of the types of social services they provide. A fundamental problem with the social service market is that it does not operate as a social service market economy or attribute a fully costed market value to the social services that organisations provide. The social service market does nothing to overcome Indigenous disadvantage as a social phenomenon. It simply provides basic service to the individual Indigenous person experiencing socio-economic disadvantage (i.e. assistance with getting an education, a job, or housing and access to childcare, health services or access to services that improve family relations). This market does not efficiently allocate resources. It does not treat not-for-profit organisations as businesses with overheads. Government pays a basic unit for a service to an individual. A unit cost that does not allow for operational or other costs. There is currently no equivalence of exchange or fair price in the social service market. Organisations have had to change the program work that they do, delivering national programs and tailoring those to the local context as opposed to meeting local needs. The government outsources the service delivery function but establishes specific requirements for Indigenous organisations to receive funding. There is no way to generate a gain or profit to reinvest into community, its development, and wellbeing.

The wide range of costs associated with the activities within the framework of the social service market are transferred onto First Nations organisations and society as a whole with no repercussions on the funding mechanism, which only pays 
for the service to the 'disadvantaged client'. The social service market fails and is incapable of ensuring the efficient allocation of economic resources required to deliver services. While it requires organisations to professionalise and operate like businesses and creates a market for social services, it fails to allow organisations to either recover the true cost of delivering services. There are no subsidies, such as funds for overhead costs or insurance, to support the operation of this 'socalled' market. Those working in First Nations organisations are paid lower wages than those working in government departments.

There are significant differences between what I call a social-service market approach and a community development approach (which emerged from Indigenous social movements) to overcoming Indigenous disadvantage and improving wellbeing, particularly in terms of the benefits of government funding of the latter, although these differences and their implications have not been explored adequately in the literature. It would appear that government social investment in Indigenous community development in Newcastle under the Australian welfare state was far more socially and economically productive in overcoming communal disadvantage, including socio-economic disadvantage, than the creation of a social service market designed to overcome individual Indigenous socio-economic disadvantage. While historically there was no actual 'development' program per se, access to infrastructure grants and block funding provided First Nations organisations with the necessary resources to achieve social independence. The provision of government funding over an extended period yielded high social and economic returns, not least by allowing the building of Indigenous social infrastructure and the creation of an Indigenous social economy.

The dilemma is that these organisations did not achieve financial independence and nor would they because they were established as community cooperatives and enterprises. Any income they generated went back into funding social programs not funded under government schemes. Overcoming community disadvantage was taking time, but it was occurring. There were downstream effects of social development on the labour market and other areas of the economy. There was upward social mobility.

The present moment underscores the precarity First Nations organisations face while remaining in a relationship of funding dependency with governments. While community development, autonomy, credibility, and the core mission and values of community enterprises are under threat, the capacity to address the housing shortages, homelessness, areas of entrenched poverty, child removal, racism, high levels of contact with the justice system, and youth disengagement experiences have been stifled in this city over the last 15 years. First Nations organisations now only receive short-term program funding rather than block grants or longterm funding assistance. The increasing focus on individualised poverty governance and governments determining what services and programs are to be made available to First Nations peoples leaves little room for overcoming community disadvantage in this city. 
Kooris living in the city of Newcastle want to control their futures. Adaptability and resilience are evident. Capacity and capability have been demonstrated. The hoops of various accountability and compliance requirements, including accreditation and leadership and governance training, have been successfully jumped through. They want to get back to the business of overcoming the disadvantage that local Kooris in this city experience and doing business their way, embedding their programs and services in relational models, language, culture, and cultural identity, as well as building a strong place and identity for First Nations peoples in this city. Nevertheless, there remains a lack of will on the part of local, state, and federal policymakers and funding bodies to support First Nations peoples to engage in place-based approaches to community development in this city. Policymakers and government funding bodies have failed to learn from and build on existing initiatives or invest in the capacity for enduring community-driven solutions and approaches. The current policy setting has severely hindered the ability of local Koori leaders and organisations to be entrepreneurial and innovative.

A successful funding model remains critical to overcoming the community disadvantage that First Nations experience in this city. At present, while First Nations organisations provide culturally safe environments and programs, the target is individual Indigenous disadvantage. What is needed is a place-based Indigenous community development approach in this city that builds on and strengthens what has already achieved. One that assists in rebuilding and strengthening relationships and networks within the community. One that allows First Nations peoples to develop solutions to the community disadvantage and social problems that First Nations peoples' experience in this city forefronting relational approaches and language, culture, and cultural identity. One that allows for cultural resurgence and a strong connection to place and space. A way to do this is to return to the model of community planning that brings First Nations peoples in this city together, allowing them to identify the disadvantages they experience, as was done on many occasions in the 1970s, 1980s, and early 1990s. The focus then becomes Indigenous community development in this city.

At best, what is on offer is a civil society model that invests in social development with a focus on social service delivery and specific areas of disadvantage (i.e. education) through building partnerships with a coalition of individual Indigenous organisations that will eventually get greater control of funding. This neoliberal civil society model differs considerably from the Indigenous social movement model adopted by Kooris in this city.

Because of the frontline work they do, those working in First Nations organisations and in regional offices of government departments in Newcastle are in a position to observe the limitations with framing Indigenous disadvantage solely in terms of socio-economic outcomes, such as getting a job and an education. As one CEO noted, 'Once you address jobs and education, you are still left with the "hard" social policy issues - housing shortages, homelessness, areas of entrenched poverty, child removal, racism, high levels of contact with the justice system, youth disengagement' (transcript CEO local Aboriginal and Torres Strait 
Islander organisation 9). Local Kooris explain how homelessness and housing shortages, child removal, domestic and family violence, high incarceration rates, and low incomes are some of the significant social problems that First Nations peoples continue to experience in Newcastle (Howard-Wagner 2019). However, as I explain elsewhere, in describing these experiences of ongoing social problems in which very little has changed in terms of high rates of child removal and incarceration and the inability to rent a house, they also draw attention to how the social service system remains racially stratified (Howard-Wagner 2019). They explain the interconnections between different social problems - for example, how family violence has far-reaching effects on homelessness among Koori women, children, and men and is a major contributor to social problems among young Kooris living in Newcastle, including school attendance, out-of-home care, and contact with the justice system (Howard-Wagner 2019). They point to how the region has the highest proportion of First Nations children and young people in out-of-home care in NSW (Virtue 2016). First Nations organisations providing services to homeless Koori youth say that Aboriginal youth homelessness is on the rise in Newcastle (ABC News 2015).

This and previous chapters illustrate the vital catalytic role Indigenous community development in cities plays in addressing the disadvantage First Nations peoples experience. It illustrates how the Australian federal policy of overcoming Indigenous disadvantage and the marketisation of social services designed to overcome Indigenous disadvantage in the neoliberal age impedes Indigenous practices and visions. It is a policy position that redefines not only Indigenous disadvantage but also the solutions to overcoming it. It is a policy position that ignores the fact that local Kooris have created their vision for overcoming the disadvantage that they experience through an autonomous, although government-funded, community development approach situated in their own identity and worldview. The recuperation and strengthening of Indigenous governance have been critical to this process. Governments have abandoned support for the pre-existing system of Indigenous community development and self-determination that operated in this city in favour of the creation of an open, social-service delivery market, a competitive market serviced by a mix of mainstream not-for-profit operations run by major Australian charities and those existing First Nations organisations. First Nations organisations and mainstream not-for-profits now compete to deliver prescribed social services to disadvantaged Indigenous individuals and families. First Nations peoples have been given limited space within the policy of the city or the state to present their epistemic credentials (Alcoff 2007; Mignolo 2000, 2009). This concerns what Farmer refers to as the 'deeper pathologies of power' or structural violence (Farmer 2004, 21).

\section{Note}

1 Our Land Our Languages, the report of an inquiry conducted by the Australian federal House of Representatives Standing Committee on Aboriginal and Torres Strait Islander Affairs, illustrated the important role that Indigenous languages play in reconnection 
with culture, kinship, land and family, as well as the devastation to communities that results when language is lost. Indigenous languages are the foundation upon which the capacity to learn, interact, and to shape identity is built (House of Representatives Standing Committee on Aboriginal and Torres Strait Islander Affairs 2012).

\section{References}

Abbott, T (2015). 'Closing the Gap: Prime Minister's Report 2015, House of Representatives, Ministerial Statements, 10 February 2015', Hansard House of Representatives, p. 440.

ABC News (2015). 'Indigenous Youth Homelessness on the Rise', $A B C$ News, www.abc. net.au/news/2015-09-09/indigenous-youth-homelessness-on-the-rise/6760240.

Aimers, J \& Walker, P (2016). 'Community Development in Aotearoa New Zealand: A Historical Journey', Whanake: The Pacific Journal of Community Development, Vol. 2, No. 2, pp. 3-12.

Alcoff, L A (2007). 'Fraser on Redistribution, Recognition, and Identity', European Journal of Political Theory, Vol. 6, No. 3, pp. 255-265.

Australian Bureau of Statistics (ABS) (2001). '2001 Census Quickstats', http://quickstats. censusdata.abs.gov.au/census_services/getproduct/census/2001/quickstat/.

Australian Bureau of Statistics (ABS) (2006). 2006 Census Quickstats, http://quickstats. censusdata.abs.gov.au/census_services/getproduct/census/2006/quickstat/.

Australian Bureau of Statistics (ABS) (2011). 2011 Census Quickstats, http://quickstats. censusdata.abs.gov.au/census_services/getproduct/census/2011/quickstat/.

Australian Bureau of Statistics (ABS) (2016). 2016 Census Quickstats, http://quickstats. censusdata.abs.gov.au/census_services/getproduct/census/2016/quickstat/.

Awabakal Medical Service (2020). 'Medical Service', www.awabakal.org/our-health/ medical-service, accessed 10 July 2020.

Awabakal Strategic Plan (2017-2020). www.awabakal.org/uploads/our-community/ Community-Forms/Awabakal-Strategic-Plan-2017-2020-final.pdf, accessed 30 October 2019.

Bodkin-Andrews, G \& Carlson, B (2016). 'The Legacy of Racism and Indigenous Australian Identity within Education', Race Ethnicity and Education, Vol. 19, No. 4, pp. 784-807.

Clarke J (2010). 'Enrolling Ordinary People: Governmental Strategies and the Avoidance of Politics?' Citizenship Studies, Vol. 14, No. 6, pp. 637-650.

Clothier, K (2006). 'Corporate (Aboriginal and Torres Strait Islander) Bill 2005: Positive or Negative Discrimination', Australian Indigenous Law Report, Vol. 10, p. 1.

Craig, D A \& Porter D (2006). Development Beyond Neoliberalism? Governance, Poverty Reduction and Political Economy. Adingdon: Routledge

Dean, M (2004). Governmentality: Power and Rule in Modern Society. London: Sage Publications.

Dodd, M (2002). 'Nation Building and Mäori Development: The Importance of Governance', paper presented at the Contesting Development: Pathways to Better Practice: Third Biennial Conference of the International Development Studies Network of Aotearoa New Zealand, Massey University, Palmerston North, New Zealand.

Eikenberry, A \& Kluver, J D (2004). 'The Marketization of the Nonprofit Sector: Civil Society at Risk?' Public Administration Review, Vol. 64, No. 2, pp. 132-140. 
Ellison, R (1952). Invisible Man. New York: Penguin Random House.

Evans-Campbell, T (2008). 'Historical Trauma in American Indian/Native Alaska Communities: A Multilevel Framework for Exploring Impacts on Individuals, Families, and Communities', Journal of Interpersonal Violence, Vol. 23, No. 3, pp. 316-338.

Farmer, P (2004). Pathologies of Power: Health, Human Rights and the New War on the Poor. Berkley, CA: University of California Press.

Feagin, JR (2006). Systemic Racism: A Theory of Oppression. New York: Routledge/Taylor \& Francis Group.

Foucault, M (2000). Essential Works of Foucault: 1954-1984, Volume Three, Power. Edited by James D Fabion.

Gardiner-Garden J (1999). 'From Dispossession to Reconciliation, Information and Research Services', Research Paper No. 27, 1998-1999, Department of the Parliamentary Library, Australia.

Goldberg, D T (1993). Racist Culture: Philosophy and the Politics of Meaning. Oxford: Wiley-Blackwell.

House of Representatives Standing Committee on Aboriginal and Torres Strait Islander Affairs (2012). Our Land Our Languages: Language Learning in Indigenous Communities. Canberra: Australian Parliament.

Howard, J (1996). 'Ministerial Statements: 1996 Progress Report to the People', House of Representatives Hansard, 11 December, pp. 8218-8226.

Howard, J (1997a). 'Transcript of the Prime Minister, the Hon John Howard, Television Interview with Kerry O'Brien', The 7.30 Report, ABC TV, 4 September, www.pm.gov. au/news/interviews/1997/730rep.html, accessed 25 April 2005.

Howard, J (1997b). 'Mining', Australian House of Representatives Hansard, 29 March, p. 4432.

Howard-Wagner, D (2006). Post-Indigenous Rights - The Political Rationalities and Technologies Governing Federal Indigenous Affairs in the Contemporary Period. PhD Dissertation, University of Newcastle, Newcastle.

Howard-Wagner, D (2008). 'Legislating Away Indigenous Rights', Law Text Culture, Vol. 12, pp. 44-68.

Howard-Wagner, D (2009). 'Whiteness, Power Relations, Resistance and the Practical Recognition of Indigenous Rights in Newcastle', Theory in Action, Vol. 2, No. 1, pp. 40-65.

Howard-Wagner, D (2010a). 'Defining Indigenous Rights Activism in Newcastle as a Collective Social Movement', in Velayutham, S, Ebert, N \& Watkins, S (eds.), Annual Conference of the Australian Sociological Association (TASA 2010). Macquarie University, Sydney Australia, p. 16.

Howard-Wagner, D (2010b). 'Scrutinising ILUAs in the Context of Agreement Making as a Panacea for Poverty and Welfare Dependency in Indigenous Communities', Australian Indigenous Law Review, Vol. 14, No. 2.

Howard-Wagner, D (2016). 'Child Wellbeing and Protection as a Regulatory System in the Neoliberal Age: Forms of Aboriginal Agency and Resistance Engaged to Confront the Challenges for Aboriginal People and Community-Based Aboriginal Organisations', Australian Indigenous Law Review, Vol. 19, No. 1, pp. 88-102.

Howard-Wagner, D (2015). 'Child Wellbeing and Protection as a Regulatory System in the Neoliberal Age: Forms of Aboriginal Agency and Resistance Engaged to Confront the Challenges for Aboriginal People and Community-Based Aboriginal Organisations', Australian Indigenous Law Review, Vol. 19, No. 1, pp. 88-102. 
Howard-Wagner, D (2017). 'Successful Urban Aboriginal-Driven Community Development: A Place-Based Study of Newcastle', CAEPR Discussion Paper.

Howard-Wagner, D (2018a). 'Governance of Indigenous Policy in the Neo-Liberal Age: Indigenous Disadvantage and the Intersecting of Paternalism and Neo-Liberalism as a Racial Project', Ethnic and Racial Studies, Vol. 41, pp. 1132-1151.

Howard-Wagner, D (2018b). 'Moving from Transactional Government to enablement? In Indigenous Service Delivery: The Era of New Public Management, Service Innovation and Urban Aboriginal Community Development', Australian Journal of Social Issues, Vol. 53, No. 3, pp. 262-282.

Howard-Wagner, D (2019). 'Success in Closing the Socio-Economic Gap, But Still a Long Way to Go: Urban Aboriginal Disadvantage, Trauma, and Racism in the Australian City of Newcastle', International Indigenous Policy Journal, Vol. 10, No. 1, pp. 1-22.

Howlett, M, Kekez, A \& Poocharoen, O (2017). 'Understanding Co-Production as a Policy Tool: Integrating New Public Governance and Comparative Policy Theory', Journal of Comparative Policy Analysis: Research and Practice, Vol. 19, No. 5, pp. 487-501.

Hudson, S (2015). CDEP: Help or Hindrance? The Community Development Employment Program and Its Impact on Indigenous Australians, The Centre for Independent Studies Policy Monograph 86. Sydney: Centre for Independent Studies.

Hummer, R A (1996). 'Black-White Differences in Health and Mortality: A Review and Conceptual Model', The Sociological Quarterly, Vol. 37, No. 1, pp. 105-125.

Hunter, B (2007). 'Cumulative Causation and the Productivity Commission's Framework for Overcoming Indigenous Disadvantage', Australian Journal of Labour Economics, Vol. 10, No. 3, pp. 185-202.

Karumaratnes, N D \& Tisdell, C (1998) 'Financial Globalisation and the Australian MacroEconomy', Discussion Paper No. 242, University of Queensland, Queensland.

Ivison, D, Patton, P \& Sanders, W (2000). Political Theory and the Rights of Indigenous Peoples. Cambridge: Cambridge University Press.

Jonas, W (1991). Awabakal, Bahtabah, Biripi, Worimi: Four Successful Aboriginal Organisations. Newcastle: University of Newcastle.

Jonas, W (2003). 'Social Justice Report 2003, Report of the Aboriginal and Torres Strait Islander Social Justice Commissioner', Human Rights and Equal Opportunity Commission, Sydney, Australia.

Lim, J (2016). 'Jayden Lim Speech and Award - National Arts and Humanities Youth Program Awards', https://vimeo.com/192382964, accessed 21 November 2016.

Maciel, R \& Vine, T (2012). 'Redistribution and Recognition: Assessing Alternative Frameworks for Aboriginal Policy in Canada', International Indigenous Policy Journal, Vol. 3, No. 4.

McCormack, F (2018). 'Indigenous Settlements and Market Environmentalism: An Untimely Coincidence?' in Howard-Wagner, D, Bargh, M \& Altamirano-Jimenez, I (eds.), The Neoliberal State, Recognition and Indigenous Rights: New Paternalism to New Imaginings. Canberra: ANU Press, pp. 273-291.

Meade, R R (2018). 'The Re-Signification of State-Funded Community Development in Ireland: A Problem of Austerity and Neoliberal Government', Critical Social Policy, Vol. 38, No. 2, pp. 222-243.

Mignolo, W D (2000). Local Histories/Global Designs: Coloniality, Subaltern Knowledges, and Border Thinking. Princeton, NJ: Princeton University Press.

Mignolo, W D (2009). 'Epistemic Disobedience, Independent Thought and Decolonial Freedom', Theory, Culture \& Society, Vol. 26, No. 7-8, pp. 159-181. 
Mills, C W (2015). 'Piercing the Veil', in Watson, V, Howard-Wagner, D \& Spanierman, L (eds.), Unveiling Whiteness in the Twenty-First Century: Global Manifestations, Transdisciplinary Interventions. Lanham, MD: Lexington Books, pp. 77-88.

Moran, M (2016). 'The Impact of Funding Modalities on the Performance of Indigenous Organisations', Australian Journal of Public Administration, Vol. 75, No. 3, pp. 359-372.

Penehira, M, Green, A, Smith, L T \& Aspin, C (2014). 'Māori and Indigenous Views on R and R: Resistance and Resilience', MAI Journal, Vol. 3, No. 2, pp. 96-110.

Price-Robertson, R (2011). 'What Is Community Disadvantage? Understanding the Issues, Overcoming the Problem (Communities and Families Clearinghouse Australia Resource Sheet)', https://aifs.gov.au/cfca/publications/what-community-disadvantageunderstanding-issues-ov.

Pyne, C (2003a). 'Pyne Calls for ATSIC Overhaul', Lateline, ABC TV, 10 March, www. abc.net.au/lateline/content/2003/s803307.htm, accessed 25 April 2005.

Pyne, C (2003b). 'Why the ATSIC Gravy Train Must Be Derailed', The Age, www.theage. com.au/article/2003/03/11/104714496152.html, accessed 25 April 2005.

Pyykkönen M (2015). 'Liberalism, Governmentality and Counter-Conduct: An Introduction to Foucauldian Analytics of Liberal Civil Society', Foucault Studies, 20 December, pp. 8-35.

Radcliffe, S A \& Laurie, N (2006). 'Culture and Development: Taking Culture Seriously in Development for Andean Indigenous People', Environment and Planning D: Society and Space, Vol. 24, No. 2, pp. 231-248.

Salamon, L (1999). 'The Nonprofit Sector at a Crossroads: The Case of America', Voluntas: International Journal of Voluntary and Nonprofit Organizations, Vol. 10, No. 1, pp. 5-23.

Salamon, L (2014). New Frontiers of Philanthropy: A Guide to the New Tools and New Actors that Are Reshaping Global Philanthropy and Social Investing. Oxford: Oxford University Press.

Sanders, W (2014). 'Experimental Governance in Australian Indigenous Affairs: From Coombs to Pearson via Rowse and the Competing Principles', Discussion Paper 291, Centre for Aboriginal Economic Policy Research, The Australian National University, Canberra.

Shaw, M (2003). 'Liberal MP Hits ATSIC', The Age, 11 March, p. 6.

Smith, D E (2008). 'Cultures of Governance and the Governance of Culture: Transforming and Containing Indigenous Institutions in Western Arnhem Land', in Hunt J, Smith D E, Garling S \& Sanders W (eds.), Contested Governance: Culture, Power and Institutions in Indigenous Australia, CAEPR Research Monograph No. 29. Canberra: Centre for Aboriginal Economic Policy Research, The Australian National University.

Spinner-Halev, J (2007). 'From Historical to Enduring Justice', Political Theory, Vol. 35, No. 5, pp. 574-597.

Spinner-Halev, J (2012). Enduring Justice. Cambridge: Cambridge University Press.

Sullivan, P (2009). 'Reciprocal Accountability: Assessing the Accountability Environment in Australian Aboriginal Affairs Policy', International Journal of Public Sector Management, Vol. 22, No. 1, pp. 57-72.

Sullivan, P (2015). A Reciprocal Relationship: Accountability for Public Value in the Aboriginal Community Sector. Carlton: Lowitja Institute.

Thomas, D, Mitchell, T \& Arseneau, C (2016). 'Re-Evaluating Resilience: From Individual Vulnerabilities to the Strength of Cultures and Collectivities Among Indigenous Communities', Resilience, Vol. 4, No. 2, pp. 116-129. 
Vanstone, A (2004). 'New Service Delivery Arrangements for Indigenous Affairs', Media Release, vIPS 012/04, 15 April.

Virtue, R (2016). 'Welfare Agency Concerned about Ongoing High Rates of Aboriginal Children in Out of Home Care in Hunter', ABC News, www.abc.net.au/news/2016-07-08/ agency-concerned-about-high-rates-of-aboriginal-care/7580930.

Walls, M \& Whitbeck, L B (2012a). 'The Intergenerational Effects of Relocation Policies on Indigenous Families', Journal of Family Issues, Vol. 33, No. 9, pp. 1272-1293.

Walls, M \& Whitbeck, L B (2012b). 'Advantages of Stress Process Approaches for Measuring Historical Trauma', The American Journal of Drug and Alcohol Abuse, Vol. 38, No. 12, pp. 416-420.

Walter, M (2009). 'An Economy of Poverty? Power and the Domain of Aboriginality', International Journal of Critical Indigenous Studies, Vol. 2, No. 1, pp. 2-14.

Walter, M \& Saggers, S (2007). 'Poverty and Social Class', in Carson, B, Dunbar, T, Chenhall, R \& Bailie, R (eds.), Social Determinants of Indigenous Health. Crows Nest: Allen \& Unwin, pp. 87-104.

Wandiyali (2020). 'Our History', http://wandiyali.com.au/about/our-history, accessed 1 July 2020.

Williams, A, Cloke, P \& Thomas, S (2012). 'Co-Constituting Neoliberalism: Faith-Based Organisations, Co-Option, and Resistance in the UK', Environment and Planning A: Economy and Space, Vol. 44, No. 6, pp. 1479-1501.

Williams, M (2014). 'Introduction - On the Use and Abuse of Recognition in Politics', in A Eisenberg, J Webber, G Coulthard \& A Boisselle (eds.), Recognition Versus SelfDetermination - Dilemmas of Emancipatory Politics, University of British Columbia, Vancouver, pp. 3-20.

Young, I M (1990). Justice and the Politics of Difference. Princeton, NJ: Princeton University Press. 


\section{Conclusion}

\section{The wilful inattentiveness to racial inequality in cities: what Black Lives Matter protests reveal about Indigenous invisibility}

Aboriginal empowerment and self-determination have become dirty words almost. I have an issue when you get told what might be best in your community. That's not allowing anyone self-determination. Not only is it not allowing that, but it's also devaluing the skills, the knowledge, and the people within an area.

(transcript 58)

Recognition of the right of Aboriginal communities to control their own affairs. Elected Aboriginal community councils should control government funds allocated to organisations and services.

(Extract from the Hunter Peoples' Inquiry into a Treaty 2000, Newcastle Aboriginal Support Group 2001, 13-14)

Protests are a way of starting a conversation. The Black Lives Matter movement, it brings a conversation. The conversation we've been trying to have since the days we were protesting black deaths in custody in the mid-1980s led to a royal commission, but of course we know that the recommendations don't always get acted upon.

But, those protests started the conversation. It does not always lead to policy or legal change, but it opens the door for the conversation. And, a permanent protest like the Aboriginal Tent Embassy, means that the door for those conversations is always open. There are lots of good people in this country who know the truth, who are willing to hear the truth, and we need to walk together now.

(Paul House, Ngunnawal and Ngambri Traditional Owner cited in Midena \& Bourchier 2020, 1)

\section{Black Lives Matter: un-silencing the injustice}

On 2 June 2020, 5,000 people turned out for the Black Lives Matter march in Newcastle's Pacific Park. It was Reconciliation Week in Australia. As Ngunnawal and Ngambri Traditional Owner, Paul House explains, the protests in cities around 
Australia, like Canberra, Melbourne, Newcastle and Sydney, were starting a conversation. 'Taking the knee' had been iconised by American football star Colin Kaepernick in 2016, who knelt at games during the American national anthem in a protest against police brutality and racism. The crowd knelt for nine minutes in silence, solidarity, and reflection and then made their way west to Civic Park, chanting 'Black lives matter' and calling for justice and change. The crowd grew along the way west to Civic Park. The placards and chants not only called for justice and an end to racism. The placards rendered visible the entrenched, enduring, injustice and racism in Australian society, declaring 'White silence is violence', 'Same story different soil' and 'I see you'. George Floyd had died after a Minneapolis police officer knelt on his neck for 8 minutes, 46 seconds. George Floyd had struggled, pleading for his life: 'I can't breathe'. They were Dhunghutti man David Dungay Jr's last words when he died in custody on 29 December 2015. On 2 June 2020, eight days after George Floyd's death on 25 May 2020, a Sydney police officer was investigated for excessive force after detaining a 16-year-old Aboriginal boy, kicking the boy's feet from beneath him before dumping the boy to the ground in the inner western Sydney suburb of Surry Hills only a short distance from the Block in Redfern.

The crowd in Newcastle was double the size of the 2,500 strong crowd that had gathered on the Foreshore on 24 November 1993 for Coming Together Day. It differed from the conciliatory efforts of Coming Together Day. Twenty-seven years on, the injustice and racism continued. The issues were the same; the difference was the longstanding white ignorance in this city as to the extent that racism and injustice continue to exist (Mills 1997). The difference was that this was no longer a journey together in reconciliation. Reconciliation and recognition from below had failed in this city. Indigenous incarceration rates continued to grow. First Nations children and young people continued to be removed from their families. The rate of Indigenous homelessness continues to increase. First Nations organisations have been reduced to a service delivery function overcoming Indigenous disadvantage. Indigenous polity and self-government is not recognised. On 2 June 2020, First Nations peoples in the city of Newcastle were again 'demanding a treaty, their birthright to exist in this country freely and not be over-policed and not be at the hands of a justice system that continues to fail First Nations peoples' (Tighe cited in Connell \& Scully 2020, 1).

First Nations peoples and non-Indigenous peoples gathered in solidarity in the cities of Adelaide, Brisbane, Canberra, Darwin, Hobart, Melbourne, Newcastle, and Sydney. Nearly 50 years on, 5,000 people gathered at 'ground zero' - the site of the Aboriginal Tent Embassy outside Old Parliament House. As the son of Ngunnawal and Ngambri Elder Aunty (Dr) Matilda House declared, they gathered 'for a whole range of rights that we need to speak up for' (Paul House cited in Midena \& Bourchier 2020, 1). Over 20,000 people gathered in Sydney alone.

The Black Lives Matter protests in Australia rendered visible that which had become once again invisible. The 432 deaths in custody since 1991 (Midena \& Bourchier 2020, 1). The First Nations peoples who make up 30 per cent of Australia's prison population (Midena \& Bourchier 2020, 1). The young First 
Nations people who make up 50 per cent of all detainees (Midena \& Bourchier $2020,1)$. The politics of denial. The profound enduring and ongoing injustice and disadvantage experienced by First Nations peoples that continues 30 years on from the Report of the Royal Commission into Aboriginal Deaths in Custody (RCIADIC) in 1991. The RCIADIC had come about as the result of Indigenous protest in the 1980s.

The RCIADIC recognised that Indigenous justice goes beyond addressing criminalisation and disadvantage to the right to sustainable community development, self-determination, and governance (Johnston 1991). It goes toward a purposeful approach to unlocking land and opportunities for social, cultural, and economic development (Johnston 1991). The RCIADIC recognised that Indigenous justice required Indigenous self-determination, recognition, governance, power, and organisational freedom. It made 339 recommendations that ranged from those about the justice system through to reconciliation, disadvantage, land needs, and self-determination (Recommendation 339, Johnston 1991).

The Black Lives Matter protests are what sociologists refer to as a 'social tipping point'. It is a potential moment of rupture and a turning point 50 years on from the protests in American cities that saw the rise of the Black Power and Red Power movements, 50 years on from those new social movements that would influence the struggle for autonomy and self-determination in American cities, but also Aotearoan New Zealand, Australian, and Canadian cities. The Black Power and Red Power movements of the late 1960s focused on creating economic, social, and political power of their own, rather than seeking integration into white-dominated society. Goenpul woman of the Quandamooka nation, and esteemed First Nations academic, Aileen Moreton-Robinson reminds us that the 1970s was a particular historical moment in which a new Indigenous subject emerged in Australian history (Moreton-Robinson 2006, 392), one that challenged the myth of patriarchal white sovereignty through a counter-narrative in which there was an 'eruption of the discourse of rights and the Australian nation's exposure to an Indigenous sovereignty claim through mass media and Indigenous demonstrations' (Moreton-Robinson 2006, 392). It was a turning point in rights discourse. First Nations peoples contested the legitimacy of the sovereign right during the late 1960s and 1970s and acted independently to create autonomy and self-determination.

The Black Lives Matter protests again raised the issue of First Nation sovereignty in Australia and 'the chance to run our own affairs, so our sovereignty can make us equal with the Australian people' (Peters-Little cited in Midena \& Bourchier 2020,1). The Black Lives Matter movement recommitted to the core tenets of self-determination (Lindsey 2019, 110). The respective movements wanted to address the poverty and powerlessness that generations of systemic discrimination and racism had imposed on so many black Americans and First Nations peoples. Black Lives Matter is a renewed call for a transformation in society. Black Lives Matter protestors, including Indigenous protestors in the Australian city of Newcastle, Canberra, Sydney and elsewhere, were calling for self-determination, 
calling for individuals and communities to control their own bodies and living conditions and determine their own destinies.

The Black Lives Matter protestors tore down and spray-painted over colonialera statues. Public outcries against racist and colonial figures were not new. The defacing of statues and street signs bearing the names of racist colonial figures were not new. Well before June 2020, there had been sticker campaigns and protests about street signage, plaques, and statues in cities. The sticker campaign in Vancouver in 2012 saw 'several street signs along Trutch Street defaced by a large white sticker that read, "Joseph Trutch was a racist bigot"' (CBC News 2012, 1). At this moment, protestors in Aotearoa New Zealand, Australia, Britain, Canada, and the United States were making visible mass incarceration as a contemporary racial project - 'a protracted legacy of colonialism, slavery, and racial segregation' (Saad 2017, 23). They tore down and defaced statues to bear pressure on colonial societies that remain vexed by institutional racism and oppression. ${ }^{1}$ The point was to send a clear message linking police power to colonial and settlercolonial methods and relationships (Singh 2014, 1095).

As relics of Australia's colonial past toppled, the Australian Prime Minister called on protestors to focus instead on 'the genuine issue of the nation's high levels of incarceration of Indigenous peoples' (Morrison 2020, 1). He boxed in Indigenous experiences, discursively containing the protests to the nation's high levels of incarceration rates. He disassociated the experiences of First Nations peoples in Australia from the United States, declaring that 'Australia when it was founded as a settlement, as New South Wales, was on the basis that there'd be no slavery' (Morrison 2020, 1). He boxed in Australia's history. He discursively contributed to perpetuating white collective amnesia. He wilfully ignored how Aboriginal deaths in custody were connected to Australia's history of colonisation, dispossession, oppression, and the legacies of systemic racialisation. The RCIADIC had formally determined the connection in 1991 (Johnston 1991).

Images and accounts of Australia's history of slavery emerged from all corners of Australia and abroad to counter the injustice that his statement caused. One image of Australia's history of slavery and brutal treatment of First Nations peoples, in particular, was widely circulated. It is the image of neck-chained Aboriginal prisoners at Wyndham, Western Australia. Days later, Morrison declared that his 'comments were not intended to give offence and if they did, I deeply regret that and apologise for that' (Hayne \& Hitch 2020, 1).

Tragically, in Reconciliation Week, the Puutu Kunti Kurrama and Pinikura First Nations people and Native Title holders were traumatised after Rio Tinto used explosives to blow up and destroy a 46,000-year-old rock shelter known as Juukan Gorge on their homelands in the Pilbaras of Western Australia (Cross 2020a, 1). The Puutu Kunti Kurrama and Pinikura First Nations people had been determined as Native Title holders in 2015. They had entered into an Indigenous Land Use Agreement with Rio Tinto Iron Ore in 2012. The recognition of Native Title of the Traditional Owners in 2015, and the Western Australian Aboriginal Heritage Act 1972, were incapable of preventing this destruction due to their legal limitations 
(Burns 2020). The Native Title Act 1993 (Cth) does not give Traditional Owners a right to 'veto' development on their country (Burns 2020). Likewise, the Aboriginal Heritage Act allows for the Western Australian Minister for Aboriginal Affairs to consent to the destruction of cultural heritage sites (Burns 2020).

Professor Marcia Langton, anthropologist and geographer and descendant of the Yiman Nation in Central Queensland, declared the loss 'heart-breaking, and moreover insulting that such a gross act of vandalism was timed to occur at the commencement of Reconciliation Week' (Langton 2020, 1). Ironically, Rio Tinto has a Reconciliation Action Plan, which Reconciliation Australia revoked on 10 June 2020 stating that: 'Respectful relationships built on trust are at the heart of Reconciliation. The blasting activity in Juukan Gorge by Rio Tinto exposes a broken relationship with the Puutu Kunti Kurama and Pinikura (PKKP) Peoples and a breathtaking breach of a respectful relationship' (Cross 2020b, 1).

We talk about reconciliation while governments still make decisions for First Nations peoples. We talk about the gap in poverty while racism remains a deadly and destructive problem in our nation. We gather to celebrate reconciliation while a young boy's feet are kicked from beneath him, and he is dumped to the ground. We gather to celebrate a week of reconciliation while a 46,000-year-old significant site is destroyed. We talk about reconciliation while we still cannot deal with the question of the place of First Nations peoples in our Constitution. Settler nations continue to engage in what Rose refers to as deeply colonising acts. Mining remains critical to the colonial encounter, as too does policing. Closing the Gap and reducing Indigenous organisations to a service delivery function entail erasure. Race only matters if you are marked by it.

Practical reconciliation as a policy in Australia continues to fail because it targets merely socio-economic gaps. It wilfully ignores the enduring impact of persistent and pervasive acts of colonial and racial violence that is the cause of long-term intergenerational trauma. It is those intergenerational effects that explain the racial gap in disadvantage. As I explain elsewhere, Kooris reveal how Indigenous disadvantage does not merely concern how First Nations people are 'firmly wedged at the bottom of Australian society' (Walter 2009, 2). Kooris continue to experience displacement, disempowerment, racism, and discrimination despite improvements in socio-economic outcomes and being at the top of the bottom socio-economic pile (Howard-Wagner 2019). Indigenous poverty governance in Australia ignores the radically disparate impact of the history of racially differentiated and discriminatory treatment (Mills 2015, 84; Howard-Wagner 2017). It dissociates Indigenous disadvantage from an understanding of past policies of racial ordering, dispossession, and trauma and contemporary forms of racism (Howard-Wagner 2009, 41; Bodkin-Andrews \& Carlson 2016, 784). Kooris associate Indigenous disadvantage with the Australian social body, its institutions, and broader social patterns (Howard-Wagner 2019).

Indigenous invisibility in cities is the wilful inattentiveness to the durability of racial inequality as an enduring injustice (Tilly 1998; Spinner-Halev 2012). It 
takes us to the inattentiveness of visibility and the act of ignoring, which takes us from the sociological to the epistemological. Wilful ignorance plays out in the epistemic positioning of First Nations peoples, who have relocated to cities, as an urban 'other' who is out of place - off-nation or off-reservation. Indigenous practices and ways of doing business in cities are myopically boxed in and interpreted through a western epistemological lens of whiteness.

Sociologist professor Chris Andersen, who reflects on being Metis in the city, offers a detailed analysis of essentialism and racialised fields as a framework for making sense of the complexities of how urban communities are epistemologically seen as 'quintessentially non-Aboriginal spaces and as such are clearly located outside the boundaries of judicial constructions of Aboriginality' (Andersen 2005, 298). This form of cultural othering concerns how settler-colonial societies create, imagine, and construct knowledge about First Nations peoples in cities. Indigeneity is characterised from a mainstream policy standpoint, and types of rights emanate from this characterisation (Andersen 2005, 308).

It is important to call these ways of seeing for what they are, which are racebased epistemologies. Race-based epistemologies are ways of seeing, interpreting, and understanding Indigenous identities, communities, institutions, governance, practices, and rights within an epistemology of whiteness. This way of seeing, interpreting, and understanding inevitably clashes with Indigenous worldviews and perpetuates conflict. How can western society as a whole take on the shared responsibility of confronting the racial paradox of how First Nations peoples are imagined in law and policy, and in everyday social interactions, and change the subjective and the structural as well as engage in the backward-looking and the forward-looking that is required to change how it imagines and socially constructs First Nations peoples in cities (Medina 2013, 25)?

It takes us to the history of race-based epistemologies deeply embedded in western ways of seeing what it means to be Indigenous. It takes us to the history of seeing the urban Indigenous 'other' in the context of cities through a deficit, commodified, or objectified mainstream lens. Governance of 'urban Indigenous peoples' who relocated to cities often only goes to managing their poverty. Political discourses in America, Canada, and Aotearoa New Zealand often portray urban Indigenous people as either living in a culture of poverty and enmeshed in cultural conflict, or their culture is depicted as an 'obstacle to successful adjustments in the city' (Todd 2000, 50). It is the deeming of urban Indigenous people as 'inauthentically' Indigenous that continues to connect colonial cultures to contemporary mainstream society (Coyle 2015). The construction of 'in-authenticity' plays a central role in the facilitation of invisibility (Lucero 2013, 10; Coyle 2015, 606). Howard and Proulx make this point well, arguing that 'to suggest that these urban Indigenous spaces are somehow artificial because they are constructed reifies the problematic idea that Indigenous people are more natural than cultural beings, and bolsters counterproductive posturing about the authenticity of urban Indigenous peoples' practices of culture' (Howard \& Proulx 2011, 4). It ignores Indigenous complexities in cities. 
The effect is that First Nations people occupy a strange corner of the urban imagination; a white social imagination that continues injustice through policies, such as Closing the Gap or significant site protection. Policy continues to conflate Indigeneity, equality, and race, yet ignores racism as a living legacy. First Nations peoples remain the subject of policy and law. Equality is limited to socioeconomic gaps. First Nations people remain out of place and displaced in policy and law itself, displaced through policies and laws that wilfully ignore Indigenous governance, development, and autonomy in cities.

The condition of seeing or the epistemic, political, and nuanced ignorance of First Nations peoples' place in society as one that is produced and sustained as outside cities must be challenged. It requires not only an end to urban Indigenous 'othering', but 'seeing' First Nations peoples and life projects in cities as something far more complex than what is presently seen.

There are significant moments of contestation that successfully disrupt the essentialised episteme of judicial and political imaginations, setting a new precedent (Andersen 2005) in which unexpectedly Indigenous practices, connections, and epistemological spaces are recognised in cities. As Chapter 6 illustrated, there have been instances in which tangible and intangible Indigenous cultural heritage have been recognised, valued, and protected in cities. The findings of Dixon and Sullivan in Darkinjung Local Aboriginal Land Council v Minister for Planning and Infrastructure \& Anor [2015] NSWLEC 1465 is a case in point. While the findings note that aspects of the evidence demonstrate the connectedness and relationship between the sites and their relationship to the cultural landscape were incomplete, it states that the experts and Aboriginal witnesses had 'provided convincing information about the significance of the Women's site in its cultural landscape, demonstrating that has high social significance and research potential in terms of the Burra Charter' (Dixon \& Sullivan 2015, 217). Importantly, a close reading of the case in and of itself reveals how western ways of seeing and knowing contested contemporary Indigenous connections to country and the significance of sites to First Nations peoples. In this case, the findings engage with those ways of seeing the world in terms of seeing the land as an Indigenous cultural landscape versus the land in terms of economic development. The findings challenge what counts as evidence and ways in which particular western intellectual and evidentiary rigour were applied by the developer to contest or refute the Stories that First Nations peoples tell.

Guringai woman Tracey Howie gave evidence about the Stories that her grandmother had passed on to her. Tracey's knowledge and connection with the site had also come from the Stories and the knowledge she had gathered over the years by listening to Stories told by family members and Elders and looking at and listening to the natural landscape (Howie, quoted in Dixon \& Sullivan 2015, 4). Howie as a holder of that cultural knowledge was not challenged, but it was her knowledge that was privileged. The determination was a significant outcome.

Through a history of the present, the book illustrates another way of seeing: how the relocation period was a turning point in the context of new Indigenous 
social movements. It was a period of rupture and a critical narrative site of Indigenous recovery and resurgence in cities (Furlan 2017, 10). First Nations peoples came together in American, Aotearoan New Zealand, Australian, and Canadian cities - restoring their capacity to be responsible for their future, creating new diasporic communities, complicating what it means to be 'Indigenous', and unifying as self-determining peoples to seek solutions to their own problems (Ahmet 2001; Heritz 2013, 43; Furlan 2017). What remains invisible is how transformative Indigenous social movements furthered the rights of First Nations peoples in cities through the creation of self-governing, community-based First Nations organisations. First Nations peoples created autonomous systems for Indigenous programs and services to be delivered to overcome community disadvantage, creating an independent service delivery infrastructure in cities.

How First Nations peoples in cities imagined their communities, framed and formulated their identities, their institutions, their business, their rights to the city is self-determination and resurgence in action. Importantly, they are 'grounded in the sustenance of an Indigenous collectivity within the city itself' (Andersen 2005, 307-308).

Cities are important political sites of collective Indigenous agency and social change (Todd 2000). First Nations peoples relocated to cities to pursue interests, aspirations, needs, goals, and objectives offered within the city landscape, resulting in strong and diverse Indigenous identities in cities. Indigenous social movements led to community building and the formation of community-based First Nations organisations in cities. It saw the emergence of new models of urban governance through community-based and community-owned First Nations organisations. Community-owned organisations were established to facilitate community efforts for community development and self-determination in cities. It is through First Nations organisations that First Nations peoples have politically organised and asserted their right to the city. The struggles, but also the successes, of Kooris living in the Australian city of Newcastle signify those of First Nations peoples in cities in Australia and elsewhere.

The city as terrain of persistent settler colonialism is contested through Indigenous struggles for life projects, land, reconciliation, the right to the city, and selfdetermination. Within cities of America, Aotearoa New Zealand, Australia, and Canada, First Nations peoples have reclaimed and carved out to varying degrees their right to the city in the late 20th century. First Nations peoples exercised their right to the city and unsettled urban governance through land claims and the reterritorialisation of sites and land-holding, as well as the reconstruction and decolonisation of urban spaces, urban reconciliation projects, and through the redefining of the relationships that structure the politics of urban self-determination.

The point of making the invisible visible serves certain ends. It makes clear the significance of Indigenous resurgence and community development to Indigenous life projects in cities. It confirms the resurgence of Indigenous practices in cities. It demonstrates the importance of Indigenous agency and governance to the building of Indigenous social infrastructure and organisations in cities. It explains how 
Indigenous social movements contest power from below. It explains the implications of Indigenous agency, autonomy, and self-determination. It illustrates the complex systems of Indigenous community development created in cities. It outlines the right of First Nations peoples to the city. It confirms the limitations of liberal projects of reconciliation and recognition. It contests the ongoing erasure of Indigenous histories in cities.

Writing this book as a history of the present serves the purpose of illustrating how the city poses its own unique opportunities, contradictions, challenges, and conflicts for First Nations peoples in their pursuit of the rights to development, to wellbeing, to preserve and benefit from natural resources, to participate in urban planning and management, to render visible Indigenous nations, to protect tangible and intangible cultural heritage and sites, and to create and belong to a community in cities.

The book introduced some important complexities to the discussion about Indigenous community development in Newcastle that arise out of that specific city. Indigenous resurgence and community development in the city of Newcastle empowered the community to not only have a political voice but to address community disadvantage, while simultaneously creating Indigenous social infrastructure and contributing to the local economy of the city. In exercising their right to self-determination, Kooris created autonomous, community-based First Nation organisations. They exercised autonomy and self-government in matters relating to their internal and local affairs. Kooris exercised their right to engage in resurgence. The book highlights the ways that Indigenous resurgence, community development, organisation, and political action strengthen Indigenous governance, autonomy, and self-determination in a way that is beneficial to not only First Nations peoples but society and the economy on the whole.

The claim for a right to the city has entailed the emergence and formulation of new claims by First Nations peoples within the local geopolitical space of cities through reconciliation in Newcastle, Albany, Adelaide, Canberra, Edmonton, Montreal, Toronto, and Vancouver. First Nations peoples in cities have endeavoured to exercise their right to participate in decision-making in matters of the city. First Nations peoples are exercising their right to revitalise Indigenous practices within the bounds of cities.

The Hunter Peoples Commitment to Indigenous Australians was developed as a local document of reconciliation. Kooris were marking the historical invisibility of Indigenous recognition in Australia, stemming from the doctrine of terra nullius in which Indigenous laws, cultures, economies, and societies were invisible (Little \& McMillan 2016, 7). Invisibility concerned the absence of a treaty. The political vision was to reclaim First Nation peoples' rightful place within the city. The political vision was to have a voice, to be heard, and to be understood. These are some of the principles enshrined in the Universal Declaration on the Rights of Indigenous Peoples (UNDRIP). Principles that underpinned the assertion of a right to the city in Newcastle before the development of UNDRIP. Today, UNDRIP serves to reinforce Koori claims. The City of Newcastle made a 
commitment to enhancing the reconciliation process with First Nations peoples and a commitment to take practical action, which included 'working together for a treaty or other instrument of reconciliation'.

In the 21st century, the 'right to the city' goes beyond being a theoretical concept first coined by French sociologist and philosopher Henri Lefebvre (1968) to an applied policy imperative. It goes beyond the New Urban Agenda - Habitat III (2016) in terms of better urban services and well-located housing for lowincome and marginalised groups and the right to a decent standard of living within the city, and the right to enjoy the benefits of urban life. That is, it goes beyond 'the general staples with respect to the content of the right-to-the-city package: environment, housing, infrastructure, economy, socio-culture, and politics' (Njoh 2017, 3). The Universal Declaration on the Rights of Indigenous Peoples elaborates on existing human rights standards and fundamental freedoms as they apply to the specific situation of Indigenous peoples in cities. The 'right to the city' needs to be rethought with First Nations peoples in the context of UNDRIP.

While cities talk the talk of inclusivity, invisible societal barriers continue to lock out Indigenous aspirations. How First Nations peoples express selfdetermination over their economic future and ensure the wellbeing of their communities is becoming far more complex in cities in the neoliberal age. Inherent to many complex problems First Nations peoples face in cities are divergent interests, conflicting goals, or competing narratives of the local governments, city planners, developers, and many residents. The neoliberal age has seen a return to paternalistic interventions in the affairs of First Nations peoples in cities. The way governments and their bureaucracies are doing business with First Nation organisations is colonising Indigenous ways of life and Indigenous social practices. Competing in a social service market manages, contains, and remaps First Nations peoples' rights. There are also profound but invisible losses for Indigenous communities in cities.

There is little room for First Nations peoples to move politically even within the politics of poverty governance in terms of overcoming Indigenous disadvantage in cities. Like elsewhere, overcoming Indigenous disadvantage is concerned with removing the barriers that prevent Indigenous peoples from fully participating as Australian citizens in Australian society, premised on the rights 'to work, to good health, to a sound education, and to a decent home' (Commonwealth of Australia 2002, 1). Successive Australian Prime Ministers over the last 20 years have targeted the 'practical areas of Indigenous disadvantage' (Howard 1997), enabling Indigenous people to get 'real jobs', become 'middle class', and assimilate into the mainstream economy (Abbott 2014). It is the individual Indigenous citizen, as opposed to Indigenous societies or communities, that is the target of government intervention. It is about first-generation human rights, not secondgeneration civil and political rights, and not Indigenous rights as set out under the Declaration on the Rights of Indigenous Peoples (UNDRIP). It is reflected in the Council of Australian Governments National Indigenous Reform Agreement Closing the Gap (Council of Australian Governments 2007), as well as in various 
policy statements made by successive Prime Ministers and Ministers for Indigenous Affairs (see Howard-Wagner 2017, 2018). Governments wilfully ignore the constellation of disadvantage experienced by First Nations peoples that are an artefact and legacy of Australia's settler-colonial history and the institutionalised structuring of Indigenous/settler social relations in Australia over 200 years (Samson 2013). This act of wilful ignorance attempts to deny difference, erase Indigenous agency, invalidate Indigenous histories, and subject First Nations peoples to further injustices, thus ignoring history and reducing Indigenous disadvantage to socio-economic circumstances. It does not end with ignoring history and the constellation of transgenerational disadvantage First Nations peoples experience. Fresh wounds are inflicted (Howard-Wagner 2019).

The best that First Nations communities in Australian cities can hope for is the capacity to make decisions about service delivery. In Australia, from the 1970s to 1990s, First Nations organisations did 'the steering and rowing' in overcoming the disadvantage as a community-wide phenomenon; today governments steer, and not-for-profit organisations row to overcome individual Indigenous disadvantage (Evans, Richmond, \& Shield 2005, 74). While there are government solutions on offer, which involve governments sharing some of the 'steering' in terms of sharing responsibilities of governance, governments and government departments still steer the solutions (Evans, Richmond, \& Shield 2005, 78). It is apparent with the Metro Urban Aboriginal Strategy (1997-2007) and the NSW OCHRE LDM (2013-present). The objective is to transform government/Indigenous relationships from a provider/recipient relationship to an actual or genuine partnership where First Nations peoples participate in decision-making about government services in their communities. It allows for self-determination about service delivery and overcoming socio-economic disadvantage. While initially the Canadian Urban Aboriginal Strategy was aimed at 'sustainable community development' (Alderson-Gill \& Associates 2005), its later iteration parallels the approach adopted under the New South Wales OCHRE Local Decision Making Model with a shift to a 'community capacity building', and then 'partnership building with all levels of government' and attention turning toward priority service delivery areas (i.e. education, employment, justice, or housing). The principle of self-determination under the OCHRE Local Decision Making approach is about Aboriginal communities having a genuine voice in determining what and how services are delivered to their communities (NSW Government 2020). It is important to distinguish between Indigenous rights and self-governance and self-determination over Indigenous service delivery to overcome Indigenous disadvantage in the context of the UAS and the OCHRE LDM. The UAS and OCHRE LDM do not enable self-government but impose governance structures on First Nations peoples. The UAS and OCHRE LDM models establish a coalition of Indigenous organisations, which govern the distribution of funding for social services. The majority of urban Aboriginal organisations in Metro Vancouver belong to a coalition called the Metro Vancouver Aboriginal Executive Council (MVAEC), 
of which there are 24 member organisations. Furthermore, the OCHRE LDM Accord model is regional rather than place-based.

As Ryan Walker points out, the justification for the Urban Aboriginal Strategy was 'not based on distinct Aboriginal rights, but on pursuing socio-economic parity between Aboriginal and non-Aboriginal citizens in urban areas' (Walker 2005, 404). Walker further demonstrates in his analysis of extracts from key policy documents, which outline the intent of the policy position, that 'the pursuit of Aboriginal self-government in the urban context has little value in and of itself, apart from whatever demonstrable value it may have for addressing the disproportionate Aboriginal socio-economic needs' (Walker 2005, 405). That is, while the Urban Aboriginal Strategy aimed to improve the social and economic conditions of Indigenous peoples living off-reserve in Canada's urban centres, improving organisation accountability and efficiency was also an underlying objective (Ilcan 2009; Ready 2012). It provided project-based funding to mostly not-for-profit organisations, including Aboriginal organisations.

In Newcastle, the only path back to some level of autonomy and self-governance presently offered is the NSW OCHRE LDM approach. Community-controlled organisations chose not to go down this path when it was initially offered. Instead, some organisations are looking for a means to achieve a new economic development agenda as opposed to a limited-service delivery approach that addresses a specific area or areas of disadvantage (Howard-Wagner 2018). Even if this was not possible, the model of governance was not the right fit for Newcastle. The earlier vision was for an elected Indigenous council to take on a governing function in terms of managing the distribution of government funding and resources to organisations, rather than an alliance of community-based organisations. The elected council would engage with the community to identify needs and then allocate funding to community-controlled organisations rather than communitycontrolled organisations making decisions about funding in consultation with the community, as is currently on the table. That is, Kooris wanted to bring decisionmaking about how funding is spent back to the level of the community.

Self-determination means transferring responsibility and power for decisionmaking to First Nations communities so they can make decisions that affect them. Coming back to UNDRIP, self-determination means having the right to finance their autonomous infrastructure. Self-determination means First Nations communities autonomously determining how to organise their resources. Nearly 30 years ago, the RCIADIC set out the role governments have to play in self-determination, which is through providing resources, policy, and agreement-making that enables community development.

Research since has reinforced this message. For example, sociologist Stephen Cornell came to a similar conclusion in 2002, after he and economist Joseph Kalt had conducted years of research in the United States for the Harvard American Indian Economic Development project (Cornell 2002). Cornell stated that they 'were yet to find a single case of an Indian nation demonstrating sustained, positive economic performance in which somebody other than the Indian nation itself is 
making the major decisions about resource allocations, project funding, development strategy, governmental organisation and related matters' (Cornell 2002, 7). He comments further that, 'in case after case, we have seen development begin to take hold when Indian nations succeed in moving outsiders from decision-making roles into resource roles, replacing them as primary decision-makers in Indigenous affairs' (Cornell 2002, 7).

What we are seeing now is that how governments fund Indigenous organisations matters. In the present moment, funding modalities are corroding the capabilities of First Nations peoples in cities to govern themselves. While block funding is no panacea, it has the potential to reform the public finance system to create enabling conditions for enhanced Indigenous governance (Moran, Porter, \& Curth-Bibb 2014, 5). Moran, Porter, and Curth-Bibb put forward an alternative model for doing so. They argue that 'building a devolved accountability framework around the organisation, rather than the centralised grant program, is a sensible alternative to multiple grants and ineffective cycles of grant risk management and attendant accountability measures' (Moran, Porter, \& Curth-Bibb 2014, 5).

Again, it is not a new proposition. The RCIADIC framed self-determination around 11 recommendations in relation to Indigenous organisations, autonomy, and self-governance. It recommended the implementation of a system of block grant funding of Aboriginal communities and organisations, 'a system whereby Aboriginal communities and organisations are provided with a minimum level of funding on a triennial basis' (Recommendation 190, Johnston 1991). It also recommended that 'sources of funding be not only allocated through a single source with one set of audit and financial requirements but with the maximum devolution and power of communities to determine the priority for the allocation of those funds' (Recommendation 188 Johnston 1991). The RCIADIC also recommended that 'the highest priority be accorded to the facilitation of social, economic and cultural development plans by Aboriginal communities' (Recommendation 203, Johnston 1991). None of those recommendations have been followed.

Wilfully ignoring Indigenous governance and development in cities means that what exists now is a range of programs organised by various levels of government and different government departments delivered across separate not-for-profit Indigenous and non-Indigenous organisations for social housing, homelessness, child intervention and wellbeing, mental health, substance abuse, family violence, and income support. Of course, interagency networks are collaborating on, say, Indigenous homelessness, Indigenous justice, or Indigenous employment. Urban Indigenous governance in this form is significantly different from the Indigenous self-governance and autonomy established by First Nations peoples for First Nations peoples and the Indigenous social infrastructure created in the areas of health, housing, education, employment, justice, and childhood wellbeing and protection. The two are not incompatible, but the former focuses on a social problem, such as homelessness, while the later focuses on overcoming community 
disadvantage. Organisations concentrate on what is happening in the community as a whole, providing a social economy, building community capacity, addressing community wellbeing, giving First Nations peoples a voice, engaging in resurgence, and overcoming community disadvantage.

For over 70 years, cities have been part of Indigenous social and political movements in Australia, Aotearoa New Zealand, Canada, and the United States. First Nations peoples in cities have asserted their visions for self-determination on their own terms. First Nations peoples have engaged in their nation-building endeavours for resurgence. While rebuilding distinct Indigenous governance, social infrastructure, and economies in cities is necessary and just, significant work is still needed. What happened in Newcastle is not an anomaly - self-determination, community development, and autonomy improved socio-economic outcomes for local Kooris. What had been achieved was only part of the effort. Those who pretend not to see Indigenous resurgence, who claim not to recognise the Indigenous development, governance, autonomy, and self-determination that I have described, or the economic and social benefits to not only First Nations peoples but the city as whole, continue to wilfully ignore that which is now in plain sight (Mills 1997, 132).

The book has illustrated how wilful ignorance is a substantive epistemic practice that has sociological effects. It has economic and social consequences. As long as this inability to see Indigenous capacity for self-governance and as long as governments refuse to hand over control, First Nations people will remain dispossessed, displaced, and disadvantaged in cities. Indigenous disadvantage will remain a significant and intractable societal problem in cities. Homelessness, out-of-home care, and incarceration rates will continue to rise. Indigenous disadvantage will remain detrimental to society as a whole.

Self-determination will not solely address disadvantage and inequality. Racism, inequality, and injustice will continue as long as those in power wilfully ignore how institutions and systems, such as the justice system and child protection and wellbeing system, continue to fail First Nations peoples. Racism, inequality, and injustice will continue as long they are disassociated from the legacies of colonialism and systemic racialisation and those legacies are ignored and the racialised systems founded in those legacies remain intact. It goes beyond redistribution then, and it goes beyond expanding state-based approaches to recognition. It goes to re-inscribing First Nations' histories and place in cities, to producing new collective imaginaries and identities in cities, to changing the way injustice and disadvantage are governed in cities, to changing the racialised systems, to letting go of the possessive investment in whiteness.

\section{Note}

1 The Black Lives Matter movement has been active since 2013 in response to the acquittal of Trayvon Martin's murderer. Trayvon was a 17-year-old African American fatally shot in Sanford, Florida on 12 February 2012. 


\section{References}

Abbott, T (2014). 'Doorstop Interview, Arnhem Land', 17 September, Prime Minister of Australia, the Hon Tony Abbott MP, https:// www.pm.gov.au/media/2014-09-17/ doorstop-interview-arnhem-land, accessed 12 June 2015.

Ahmet, R (2001). 'Taking Back Responsibility and Restoring Aboriginal Capacity in Cape York Peninsula', Opening address to the Northern Summit 11 September, Cape York Partnerships, Queensland.

Alderson-Gill \& Associates Consulting Inc (2005). Urban Aboriginal Strategy Pilot Projects Formative Evaluation: Final Report. Ottawa: Office of the Federal Interlocutor, Indian and Northern Affairs Canada, www.aadnc-aandc.gc.ca/eng/1100100014373/ 1100100014378

Andersen, C (2005). 'Residual Tensions of Empire: Contemporary Métis Communities and the Canadian Judicial Imagination', in Reconfiguring Aboriginal State Relations. Canada: The State of the Federation, pp. 295-325.

Bodkin-Andrews, G \& Carlson, B (2016). 'The Legacy of Racism and Indigenous Australian Identity Within Education', Race Ethnicity and Education, Vol. 19, No. 4, pp. 784-807.

Burns, M (2020). 'Reconciliation Week 2020: Twenty Years and Still Waiting. . ', UNE Connect, www.une.edu.au/connect/news/2020/06/reconciliation-week-2020-twentyyears-and-still-waiting, accessed 20 June 2020.

CBC News (2012). 'Sticker Campaign Targets "Racist" B.C. Lieutenant-Governor', $C B C$ News, 14 August, www.cbc.ca/news/canada/british-columbia/sticker-campaign-targetsracist-b-c-lieutenant-governor-1.1205660, accessed 2 July 2020.

Commonwealth of Australia (2002). Executive Summary of the Commonwealth Government Response to the Council for Aboriginal Reconciliation Final Report-Reconciliation: Australia's Challenge. Canberra: Australian Government Printing Service.

Connell, C \& Scully, A (2020). 'Black Lives Matter Movement Hits the Streets of Newcastle After Police's Failed Supreme Court Bid', ABC News, www.abc.net.au/news/2020-0706/black-lives-matter-movement-hits-the-streets-of-newcastle/12424340, accessed 6 July 2020.

Council of Australian Governments (2007). National Indigenous Reform Agreement Closing the Gap. Canberra: Australian Government Printing Service.

Cornell, S (2002). 'Nation - Building and the Treaty Process', Indigenous Law Bulletin, Vol. 32, No 5, p. 7.

Coyle, J (2015). 'Where Are All the Koori football players? The AFL and the Invisible Presence of Indigenous Victorians', Sport in Society, Vol. 18, No. 5, pp. 604-613.

Cross, H (2020a). 'Traditional Owners Distraught After Destruction of 46,000-Year-Old Rock Shelters', National Indigenous Times, 28 May, https://nit.com.au/traditional-owners-distraught-after-destruction-of-46000-year-old-rock-shelters/, accessed 6 July 2020.

Cross, H (2020b). 'Reconciliation Australia Revokes Rio Tinto's RAP', The National Indigenous Times, 10 June, https://nit.com.au/reconciliation-australia-revokes-riotintos-rap/, accessed 7 July 2020.

Dixon C \& Sullivan, A C (2015) 'Judgment', Darkinjung Local Aboriginal Land Council v Minister for Planning and Infrastructure \& Anor [2015] NSWLEC 1465.

Evans, B, Richmond T \& Shields J (2005). 'Structuring Neoliberal Governance: The Nonprofit Sector, Emerging New Modes of Control and the Marketisation of Service Delivery', Policy and Society, Vol. 24, No. 1, pp. 73-97. DOI: 10.1016/S1449-4035(05)70050-3. 
Furlan, L M (2017). Indigenous Cities: Urban Indian Fiction and the Histories of Relocation. Nebraska: University of Nebraska Press.

Hayne, J \& Hith, G (2020). 'Scott Morrison Says Slavery Comments Were About New South Wales Colony, Apologises for Causing Offence', Australian Broadcasting Commission News, 12 June, https://www.abc.net.au/news/2020-06-12/pm-apologises-offencecaused-slavery-comments-clarifies-remarks/12348716, accessed 21 June 2020.

Heritz, J (2013). 'Urban Aboriginal Self-Determination in Toronto', in Newhouse, D et al. (eds.), Well-Being in the Urban Aboriginal Community: Fostering Biimaadiziwin. Toronto: Thompson Educational Publishers.

Howard, J (1997). 'Transcript of the Prime Minister, the Hon John Howard, Television Interview with Kerry O'Brien', The 7.30 Report, $A B C T V$, 4 September, www.pm.gov. au/news/interviews/1997/730rep.html, accessed 25 April 2005.

Howard-Wagner, D (2017). 'Successful Urban Aboriginal-Driven Community Development: A Place-Based Study of Newcastle', CAEPR Discussion Paper.

Howard-Wagner, D (2018). 'Moving from Transactional Government to Enablement? In Indigenous Service Delivery: The Era of New Public Management, Service Innovation and Urban Aboriginal Community Development', Australian Journal of Social Issues, Vol. 53, No. 3, pp. 262-282.

Howard-Wagner, D (2019). 'Success in Closing the Socio-Economic Gap, But Still a Long Way to Go: Urban Aboriginal Disadvantage, Trauma, and Racism in the Australian City of Newcastle', International Indigenous Policy Journal, Vol. 10, No. 1, pp. 1-22.

Ilcan, S (2009). 'Privatizing Responsibility: Public Sector Reform Under Neoliberal Government', Canadian Review of Sociology, Vol. 46, No. 3, pp. 207-234.

Langton, M (2020). For Aboriginal Australians the Loss Is Heart-Breaking, and Moreover Insulting That Such a Gross Act of Vandalism Was Timed to Occur at the Commencement of Reconciliation Week. The University of Melbourne, https://sustainable.unimelb.edu. au/news/juukan-gorge, accessed 5 July 2020.

Lefebvre, H (1968). Le Droit à la ville. Paris: Anthropos.

Lindsey, L (2019). 'Black Lives Matter: Grace P. Campbell and Claudia Jones-An Analysis of the Negro Question, Self-Determination, Black Belt Thesis', Journal of Pan African Studies, Vol. 12, No, 9, pp. 110-143.

Little, A \& McMillan, M (2016). 'On the Wrong Track: Why Australia's Attempt at Indigenous Reconciliation Will Fail', The Conversation, p. 20.

Lucero, N (2013). 'Being Indian in the City: Generational Differences in Negotiation of Native Identity among Urban Based American Indians', in Andersen, C \& Peters, E (eds.), Indigenous in the City: Contemporary Identities and Cultural Innovation. Vancouver: UBC Press, pp. 193-215.

Medina, J (2013). The Epistemology of Resistance: Gender and Racial Oppression, Epistemic Injustice, and the Social Imagination. Oxford: Oxford University Press.

Midena, K \& Bourchier D (2020). 'Aboriginal Tent Embassy in Canberra Still the Ground zero for First Nations People Nearly 50 Years', The Canberra Times, 29 June, www. abc.net.au/news/2020-06-29/aboriginal-tent-embassy-a-protest-which-is-alwaysopen/12397696, accessed 29 June 2020.

Mills, C W (2015). 'Piercing the Veil', in V Watson, D Howard-Wagner \& L Spanierman (eds.), Unveiling Whiteness in the Twenty-First Century: Global Manifestations, Transdisciplinary Interventions. Lanham, MD: Lexington Books, pp. 77-88.

Moran, M, Porter, D \& Curth-Bibb, J (2014). Funding Indigenous Organisations: Improving Governance Performance Through Innovations in Public Finance Management in Remote Australia, Closing the Gap Clearing House, Issue Paper 11, Australian 
Government, Australian Institute of Health and Welfare, Australian Institute of Family Studies, Canberra, Australia.

Moreton-Robinson, A (2006). 'Towards a New Research Agenda? Foucault, Whiteness and Indigenous Sovereignty', Journal of Sociology, Vol. 42, No. 4, pp. 383-395.

Morrison, S (2020) 'Interview with Ben Fordham, 2GB, Transcript', Prime Minister, 11 June, https://www.pm.gov.au/media/interview-ben-fordham-2gb-4, accessed 21 June 2020.

New Urban Agenda - Habitat III (2016). http://habitat3.org/the-new-urban-agenda/.

Njoh, A J (2017). “"The Right-to-the-City Question” and Indigenous Urban Populations in Capital Cities in Cameroon', Journal of Asian and African Studies, Vol. 52, No. 2, pp. 188-200.

NSW Government Aboriginal Affairs (2020). 'Local Decision Making', www.aboriginal affairs.nsw.gov.au/working-differently/local-decision-making.

Ready, C (2012). 'From Frayed Rope to Tight Strings: Negotiating Non-Profit Governance in a Neoliberal State', Canadian Graduate Journal of Sociology and Criminology, Vol. 1, No. 1, pp. 27-42.

Saad, M (2017). 'Mass Incarceration as a Contemporary Racial Project in North America and its Stratification Across Racialized and Gendered Lines', Prandium: The Journal of Historical Studies at U of T Mississauga, Vol. 6, No. 1, pp. 23-50.

Samson, C (2013). A World You Do Not Know: Settler Societies, First Nations Peoples and the Attack on Cultural Diversity. London: Human Rights Consortium, School of Advanced Study, University of London.

Singh, N P (2014). 'The Whiteness of Police', American Quarterly, Vol. 66, No. 4, pp. 1091-1099.

Tilly, C (1998). Durable Inequality. Berkley, CA: University of California Press.

Todd, R (2000-2001). 'Between the Land and the City: Aboriginal Agency, Culture and Governance in Urban Areas', The London Journal of Canadian Studies, Vol. 16, pp. 49-67.

Walker, R C (2005). 'Social Cohesion? A Critical Review of the Urban Aboriginal Strategy and Its Application to Address Homelessness in Winnipeg', The Canadian Journal of Native Studies, Vol. 25, No. 2, pp. 395-416.

Walter, M (2009). 'An Economy of Poverty? Power and the Domain of Aboriginality', International Journal of Critical Indigenous Studies, Vol. 2, No. 1, pp. 2-14. 


\section{Index}

Aboriginal and Torres Strait Islander

Commission (ATSIC) 55, 141, 153

Aboriginal and Torres Strait Islander

Commission Act 1989 (Cth) 55

Aboriginal and Torres Strait Islander

Heritage Protection Act 1984 (Cth) 134

Aboriginal and Torres Strait Islander peoples 2, 6

Aboriginal Associations and Corporations Act 197655

Aboriginal Councils and Associations Act 1976 (Cth) 55

Aboriginal Cultural Heritage 5

Aboriginal Friendship Centres 49, 52

Aboriginality 57

Aboriginal land rights 130-132

Aboriginal legal Service 2, 55, 58, 73

Aboriginal Medical Service 2

Aboriginal Medical Service Cooperative Ltd 58

Aboriginal medical services 2, 55

Aboriginal Tent Embassy 8

absence 146-149; malevolent absence 5, 13

adaptation $158-160$

agency $10,16,19,36,51,53,59,74-75$,

$143,160-161,178-179$; erasure of

Indigenous agency $116,150,181$

Alaska 10

Albuquerque and Sandoval County 10

Alcatraz 8, 52

alienation 133-137

All Nations Canoe Gathering at False Creek 97

ALRNT Act 54

Altamirano-Jimenez, Isabella 106

America 1, 174

American Indian Centre 2, 50-52

American Indian Movement 8
American Indians 52

Anishnawbe Health 73

anti-colonial Indigenous struggles 9

Aotearoa 1

Arnott, William 35

Arnotts Biscuit Factory 35

assimilation 28, 33, 51, 63, 145

Associations Bill 197555

Auckland 2

Australia 1, 5-6, 28, 56-58; policy of Indigenous disadvantage 151-155; political landscape 53-56

Australian Bureau of Statistics (ABS) 147

Australian Capital Territory 54

Australian Parliament House 8

authenticity 7

autonomy 51, 59; Indigenous 4, 12, 16, $32-33,51,75,147,150-151,158-159$, $177,179,183$; in internal and local affairs 179; legitimacy 173; Newcastle 182, 184; relational 75; stranglehold governments 154 ; strategies 160 ; struggle for 173; under threat 163

Awabakal Aboriginal Cooperative 1-3, 7, 11; Annual General Meeting 64; creation 60-67; in Newcastle 49, 50, 55, 58-60

Awabakal First Nations peoples 30; sovereignty, subjugation 4-5

Awabakal Local Aboriginal Land Council 3

Awabakal Medical Centre 6, 35

Awabakal people 15

Awabakal preschools 6

Barcham, Manuhuai 56

Behrendt, Larissa 13

Birabahn (Eagle Hawk) 77, 104

Black Hawk War 30

Black Lives Matter 171-184 
Black Ned's Bay 32

Block ('the') in Redfern 2, 48, 172

Brisbane 1

British settler-colonial nations 30; see also settler-colonial societies/cities

California 10

Canada 1, 28

Canadian Urban Aboriginal Strategy 181

Canberra 8

Carleton, S. 123

Carrington 3

Carrington community 3

Central Coast 31

Central Region Site Committee 65

Chicago 1-3, 14

Chicago American Indian Centre 1, 51-52; see also American Indian Centre

Cidro, J. 52

cities: community development $1-20$; as critical sites of Indigenous protest 8 ; highlight communities in 29 ;

Indigenous civil society institutions 49 ; Indigenous community development 50; Indigenous community movements 49-50; Indigenous ethic of care 88-90; Indigenous resurgence 1-20; Indigenous social economies 88-90, 155-157; non-metropolitan urban areas and 56-57; relocation to $33-35$; rural areas to 35-37; wounded settler 13-14; see also Indigenous cities

Civic Centre of San Francisco 10

civil disobedience 49-50, 61

Closing the Gap 4, 84, 98-99, 149-151, $175,177,180$

Clouthard, Glen 14, 125

Collis, Paul 12, 60

colonialism 133; colonial amnesia 30; legacies of $20,174,184$; settler 1,9 , $13,30,33,124,130,178$; socio-spatial technology of 107

Columbia University 9

Columbus Day 9-10

Columbus Day celebration 10

Coming Together Day 98

Commonwealth Department of Aboriginal Affairs 54

Commonwealth Development Employment Program (CDEP) 80-82, 153, 161

Community Advancement Cooperative Society 62 community-based organisations 2

community building $8,15,17,37,50-53$, 59-62, 76, 89-90, 100, 141, 147, 178

community development: approach 163 ;

Canadian Urban Aboriginal Strategy 181; capacity for 60; city as critical space of

1 ; community efforts for 178 ; community entrepreneuring 88 ; community

organising and 143; competing identities

144; cultural identity 2, 143; First

Nations peoples agency $16,74,143$,

155, 164; Indigenous 6-8, 11-14, $16,18,43,50,53,74-76,79,97,99$, $141-147,152-153,158-161,163-165$, 173, 178-179; Indigenous institutions 2; innovative phase of 79; invisibility of Indigenous 5-8; maintenance of 6; neoliberal poverty governance on 144 ; Newcastle 184; place-based approaches to 164; technology of government 144 community of resistance 8,49 community-owned organisations 2, 84 Coquun (Hunter) River 31, 103, 126

Cornell, Stephen 29

Corntassel, Alfred 106

Corntassel, Jeff 106

Coulthard, Glen 107

critical narrative site 29

cultural appropriate services for 3

cultural centre 73

cultural meeting place for 52

cultural needs 66

cultural relationships 12

cultural resurgence 1

Currawong project 101-105

decolonisation $8,10,13,16,53,56$, 104-105, 127, 178

Delaware, the 9

Delaware Nation 9

Department of Aboriginal Affairs 55

disobedience 49-50, 61; see also civil disobedience

displacement 133-137

dispossession 15, 17, 29-31, 33, 36, 43, $89,103,105,109,125,127,130-131$, $162,174-175$

Dixon, C. 134

dual signage 111-112; see also Newcastle

Eagle Hawk 104

Eastern Nitrogen 35 
economy of care $2,76,89-90$

Ellison, R. 7, 142

enacting visibility $8-12$

entrepreneuring 88 ; collective 90 ; community $18,72,75,87-88,89$; enterprise and 50-51, 87; Indigenous $18,87-88$

epistemological spaces 177

estrangement in place $133-137$

ethics $88-90$

Federal Office of Indigenous Affairs 42

First Nations peoples 142-152, 159-160, 174-184; affairs of 54; in American 1, 174; in Aotearoan 1, 49; in Australia 28, 49, 105; in Australian 1; autonomous association of 62; Awabakal 15, 30-31, 126; black Americans and 173; in Canada 28, 49; in Canadian cities 1; in Carrington 3; as colonisation of the landscape 127; Columbus Day celebration 10; community development 75,179 ; cultural appropriate services for 3; cultural centre for 73 ; culturally grounded foundation 75 ; cultural meeting place for 52; cultural needs 66; cultural relationships 12 ; cultural resurgence 1 ; deterritorialisation of 30 ; disadvantage $8,116,173$; disappearing 9; discourses in nation-states with 13 ; dispossessing 9, 15; economic needs of 51 ; equal wages to 43 ; erasing 9; experience of 29; federal law 15 ; government administrative regimes 7 ; historical racialised cycle of adaptation 7 ; histories of 51,122 ; homeless 100; home-place 2; Hunter Peoples Commitment to 11; as 'in-authentically' 13; Indigenous disadvantage 90 ; of Indigenous land 54; Indigenous landscape-shaping for 124; Indigenous organisations 7, 9, 74; Indigenous/state relations and 113; invisibility of 13 ; invisible 143; invisible infrastructure 12; knowledge about 14; Lenape 9; liberty of 33; life projects of 15; in Montreal 122; movement moment 2; National First Nations Peoples Day 97; nation-tonation relationship with 122; needs of 92, 115; neoliberal poverty governance as 33; Newcastle 34, 39-40, 43, 164, 172; of New South Wales 32, 103, 130; in New Zealand 49; non-Indigenous and 96-97, 172; Northern Territory
55; not-for-profit charity organisation 80; notorious slums areas 40; Ohlone 30, 136; in Oppenheimer Park 100; organisations 4, 9, 51; political positionality of 131,133 ; political pressure 10; political relationships 12; populations of 28; post-war period 1, 48; post-World War II 2; Potawatomi 30; from processes of decisionmaking 12; rebuilding processes 53; Relocation plan 52; rights of 101, 106, 122; as 'rooted people' 29; from the San Francisco Bay area 8; selfdetermination 59; self-determination struggle 3 ; in settler-colonial societies 13, 28, 48-67; social processes of 145 ; societal relationships 12 ; sovereign peoples 15 ; struggle against the location 13; struggle for rights 8 ; success of urban 13; sunrise ceremony 10; supporters 9-10; in Sydney 40; territorial alienation 30 ; territory of 15; in Toronto 72; in United States 49; unsettling process 9 ; visual message 10 ; white intrusion 4; whiteness and social relations 98 ; whiteness as property 14; white systems of governance on 55

FitzMaurice, K. 52

fragility of hopeful spaces $112-114$

Fulton Street 10

funding dependency 160-165

Furlan, Laura 29

gentrification 2-3

George Washington High School 11 gesture 107-110

Giant Kangaroo 5

governance: Awabakal Cooperative $63,79,106,132$; city-council styles of 55; community and cultural 90 ; community-based organisations 63 ; Indigenous forms of $2,6-8,18,55,63$, $74-75,85-87,90-92,100,175,177$, 183-184; local 76; neoliberal poverty 4, 33, 141-165, 176; organisational 6, 78 ; self $12,18,56,60,181-182,183$; urban Indigenous 157-158; western $7,55,87$; white systems of 55 ; of Yarnteen 83

governing $7,8,20,51,74-75,76,86-87$, $100,124,142,182$; see also selfgoverning governmentality $7,19-20$ 
Graham, Katherine 75

Gunya Hotel 31

Guringai people and Darkingjung people 15

Harlem River field 10

Harris, Cheryl 14, 133

Hautzinger, D. 52

Havemann, Paul 8

Heath, J. 41, 62

Henry, E. 31-32

Henry, W. 31-32

hidden in plain sight $3,5,7,48,72-92$, $123,141,145$

Howard, H. 60

Howie, Tracey 135

Hunter Street, Newcastle 5

Ibis hotel 5

identity formation $16,57,74$

inauthenticity 13

Indian Placement and Relocation Program 28

Indigeneity 56

Indigenous: adaptation 158-160; authenticity 7 ; community development 141-165; disadvantage 6; disadvantage, Australian policy of 151-155; displacement 3; economy 2; ethic of care 88-90; family resettlement program 42-43; governing and institution building 76-84; grassroots movements 8 ; institutions, and social infrastructure 1; knowledges 18, 91, 124; land claims, politics 128-130; legitimacy 7 ; life projects $33-35$, 50-51; mobilisation 9; occupations 8 ; organisations $1,6,7,8-12,50$, 51; policy 155-157; political agency 96-116; practices and governance 90-92; relocation 3; relocation programs $32-35$; rights 49 ; selfdetermination 51, 56-58; social economies 72-92, 155-157; social movements 1, 50; social relations 6; socio-economic disadvantage 149-151; sovereign presence, urban space void of 14-15; urbanisation 28

Indigenous Advancement Strategy (IAS) $153-154$

Indigenous autonomy 4, 12, 16, 32-33, $51,75,147,150-151,158-159,177$, 179,183

Indigenous cities: invisible histories of 30-33; see also cities

Indigenous Cities (Furlan) 29
Indigenous communities: of association in cities 51; development 6-7, 50; development and cultural resurgence 5-8; entrepreneuring 87-88; invisibility of 5-8; movements 49-50; protocols $18,48,91,98,105$; in settler-colonial cities 50-53; ways of doing business $17,18,60,75,92,176$

Indigenous disadvantage, overcoming 146-149

Indigenous Family Resettlement Scheme 28,42

Indigenous resurgence: in cities 1-2; complex social and cultural process 10 ; rendering visible 12,16 ; settler-colonial cities 28-43, 48-67; social processes of 3 ; struggles in relation 19

injustice 10, 36, 105, 107, 116, 130, 131, 133, 146; enduring 146, 172, 175; spatial jurisprudential 131; un-silencing the injustice 171-176

inner-city industrial harbourfront 3

Intertribal Friendship Centre in San Francisco Bay 50

Intertribal Friendship House 2, 74

invisibility $12,133-137$; as

epistemological 12, 14, 176; race and the invisibility metaphor 13 ; as sociological 12, 14, 176

invisibility/visibility, intertwining of 12 invisible loss $13-14$

John Jay Hall 9

Joseph, Robert 97

Kanyenkeha (Mohawk) Language 73

Keating, Paul 105

Kelly, Ray 96-97

Kentucky Fried Chicken fast-food restaurant 5

Khanterin 126

Koori community 6; leadership 84-87; relocation 35-37

Kukutai, Tahu 56

Lamb, Uncle Billy 3

Lenape First Nations peoples 9-10

Lenape Pow Wow 9

liberalism 19, 106-107; liberal recognition 19; misrecognition 12; neoliberalism 20,149

life histories, Kooris Elders 37-41

Lipsitz, G. 133

Little Earth in Minneapolis 2 
Lobo, Susan 60

Los Angeles 10

Maddison, Sarah 57

Manukau Urban Maori Authority 1, 50

Maori Women's Welfare League and Maatua Whangai 53

Margaret, Q. 31

marking whiteness: protocols of whiteness 108; white monuments 5, 126, 127; whiteness as power 13; white spaces 14 , 122-137

Masonic temple 2

Mattara 98

Mattara Festival 98

Maynard, John 31

McCaskill, D. 52

McGill University 123

McGregor, Russell 56

Meehan, Donna 98

Michigan 10

Miller, J. 8, 49, 56

Mills, C. 20

Minneapolis 2

Minnesota 10

Miromaa 141

Miromaa Language and Technology Centre 6, 141

misrecognition 12

Mitchell, I. S. 42

"Mixed Mob" 60

mobilisation 9, 11

Morgan, George 33

movement moment 2

Muloobinba 14

Muloobinbah 5, 109, 126

Multnomah County 10

Nadasdy, Paul 106

National Aboriginal Consultative Committee (NACC) 54

National Aboriginal Council (NAC) 54

National First Nations Peoples Day 97

Native Canadian Centre of Toronto 2, 50, $51,72-74$

Ned, K. 31-32

neoliberal bureaucratisation 158-160

neoliberalism 20, 149; see also liberalism neoliberal poverty $4,33,141-165$

neoliberal poverty governance $141-165$

Newcastle 1-5, 34, 56, 110

Newcastle City Council region 5

Newcastle Regional Footprint 5

Newcastle Trade Hall Council 62
Newhouse, David 12

New Mexico 10

New South Wales (NSW) 5, 28, 32, 63

New South Wales Aborigines' Protection Board 64

New South Wales Government 135

New York 2

New Zealand 1, 28

Ngunnawal and Ngambri peoples 15

non-metropolitan urban areas 57

Norman, Heidi 56

Northern Territory 55

Novocastrian Tales (Walsh) 104

NSW Aboriginal Land Rights Act 198355

NSW Aborigines Protection Act 32, 36

NSW Department of Aboriginal Affairs 65

NSW Land and Environment Court 135

NSW National Parks and Wildlife Service Advisory Committee 65

Oakland 2, 3, 14

Oakland Intertribal Friendship House 1, 51,74

occupations 8

Ohlone First Nations peoples 15, 30

Old Wickham Infant School 4

Olympia 10

omission 146-149

Oregon 10

organisational governance 157-158

Parliament Aboriginal Councils 54-55

period of rupture 29

Phillips, Nathan 9

Phoenix 2

Phoenix Indian Center 1, 50, 51-52, 74

policy silence $146-149$

policy spaces $6,13,143$

political mobilisation 11

political space 11,179

possessive investment in whiteness

$125-128$

post-industrial neoliberal city $125-128$

post-war relocation 48

post-World War II period 32, 33-35

Potawatomi First Nations people 15, 30

poverty 3; culture of 176; Indigenous 175; neoliberal 4, 33, 141-165; politics of

180; powerlessness and 173

power relations 104, 108

pow wows $9,10,52,73$

practical reconciliation 114-116, 149-151

protocols 14, 18, 91, 98, 105, 108-109 
public space 10

public spaces $10,98,104,125,126$

\section{Queensland 63}

Racial Discrimination Act 113

racialisation 7, 32, 108, 146-147, 149, 154, $158,159,160$; cities as deeply racialised 13-14, 129, 133; deracialisation 108; racialised cycle of adaption 7 ; racialised effects of neoliberal social projects 20 ; racialised experience 90 ; racialised segregation 17, 34; wilful inattentiveness to racial inequality 19

racial(ised) projects $20,33,146-147$, 149,159

racial ordering 146, 151

recognition (politics of) 3, 4, 7, 8, 9, $14,19,92,107$; new politics of nonrecognition 3,145 ; recognition from below 16; space of misrecognition 12 reconciliation 96-116; practical 114-116, 149-151; transformative reconciliation $18,105,114,124$

Reconciliation Action Plan (RAP) 98

Redfern 3

Redhawk Native American Arts Council 9 relational autonomy 75

relocation 28-29, 33-35; Indigenous 3; of Indigenous community movements 49-50; post-war 48; urban 53; see also Indigenous

resilience versus resistance 158-160 resistance $1,8,9,65,159$; agency and resistance 10, 160-161; 'community of resistance' 8, 49; as a productive counter-conduct 104; resisting settler state projects 9; resurgence as 1 ; social organisation as more than resistance 59; of whiteness, power, domination, and racism 127

resurgence: cultural $1,5-8,11,16,17-19$; Indigenous 1-3, 7-19, 28-43, 48, 143, $145,178-179,184$; Newcastle 2

rights 49

right to the city $105-107$

Robertson, Gregor 97

Ruegg \& Ellsworth v City of Berkeley 135

Samson, Colin 106

San Francisco 10

San Francisco Bay 2, 8, 14, 52

San Francisco Friendship Centre 8

Scott, J.C. 32 segregation $17,32,34,40,174$

self-determination 51; see also Urban

Indigenous self-determination

self-governance $12,18,56,60,181-182,183$

self-governing $1,3-4,51,53-55,78,85$,

$145,161,178$

settler colonialism $1,9,13,30,33,124$,

130,178

settler-colonial societies: First Nations

peoples 28

settler-colonial societies/cities 14, 30; First

Nations peoples in 13, 48-67; history of

30; Indigenous community in 50-53; of

Indigenous resurgence 28-43; see also

British settler-colonial nations

Short, Damien 106

Smith, Bill 62, 97

social body 7, 143, 175

social capital 64, 65-66, 85-86, 154, 158

social economies $1,7,12-13,51,72-92$,

$143,155-157,163,183-184$

social infrastructure $1,6-7,13,50-51,67$,

$73,75,89-90,105,144,152,179,183$

social mobilisation 9

social projects 20,147

social service system 4

spaces: critical 13; epistemological

177; of misrecognition 12; policy

$6,13,143$; political 11, 179; public

$10,98,104,125,126$; urban 14, 28,

$106,109,125,127,178$; white 14 ,

$122-137$

Special Olympics Asia Pacific Games 34

Spinner-Halev, J. 146, 175

stories 37-41; see also life histories,

Kooris Elders

St. Paul 10

subjugation $4-5,32$

Sullivan, A. C. 134

Sydney 1-2

Tāmaki 15; see also Auckland

Tapsell, P. 88

terra nullius 13,126

Te Whanau O Waipareira 1, 53, 74

Texas Shanty Town 3

Thirrilmun 126

This Is Not A Peace Pipe (Turner) 107

Threlkeld, Reverend 31

Tobin, Peter 57

Tomiak, Julie 30, 107

Toronto 2

Tranby Aboriginal Cooperative College in Glebe 63 
transformative Indigenous social movements 1

transformative reconciliation 18,105 , 114,124

Traverse City 10

treaty $11,15,19,54,96-97,99,106$, $109-110,112-114,172,179-180$

Treaty of Chicago 30

United Nations Declaration on the Rights of First Nations peoples (UNDRIP) 122

United States 1, 28-29

University California Berkeley 136

University of New England 42

unsettling 9; social process of unsettling, the 9-10; unsettling the possessive investment in whiteness 10

Uptown in Chicago 2

urban Aboriginal 57

Urban Indian Relocation Program 28

urban Indigenous governance 157-158

urban Indigenous self-determination 51

urbanisation 28; see also Indigenous

urban relocation 53

urban space 14, 28, 106, 109, 125, 127, 178

urbs nullius 14

Vancouver 2, 3

Vancouver Aboriginal Friendship Centre 1, $50,51-52,74$

Vermont 10

visibility 12 ; enacting visibility 12
Walsh, Paul 103

Wandiyali Aboriginal and Torres Strait Islander Corporation 6, 74

Washington 10

Weber, Max 61

Welcome to Country 34

West Berkeley Shellmound 135

Wheeler-Howard Act 55

Whibayganba 126

White Australia policy 54

whiteness: adaptive strategies $122-137$; benevolent whiteness 124; disrupting 104; as epistemological 176; intrusion 4; possessive investment in $10,14,184$; as property 14,133 ; protocols of whiteness 108; settler colonial whiteness in cities 30, 106, 123, 124, 129; social relations 98; spaces $14,98,122-137$; the system 143; systems of governance on 55; tokenistic gesturing 107-110

Wickham 3

Wigwamen Housing Corporation 73

wilful ignorance 7, 107, 116, 144, 176, 181; white ignorance 172

Worimi First Nation people 31

wounded settler cities 13-14

Wright, Jim 65

Yarnteen Aboriginal and Torres Strait Islander Corporation 6

Yashar, Deborah 8

Young, Iris Marion 106 